\title{
A GARANTIA DA RAZOÁVEL DURAÇÃO DA PERSECUÇÃO PENAL
}

Dissertação apresentada à Faculdade de Direito da Universidade de São Paulo como requisito parcial à obtenção do grau de mestre na área de concentração de Direito Processual (Processo Penal).

Orientadora: Prof ${ }^{\mathrm{a}}$. Dr ${ }^{\mathrm{a}}$. Maria Thereza Rocha de Assis Moura 
THAÍS AROCA DATCHO LACAVA

\section{A GARANTIA DA RAZOÁVEL DURAÇÃO DA PERSECUÇÃO PENAL}

FACULDADE DE DIREITO DA UNIVERSIDADE DE SÃO PAULO SÃO PAULO - 2009 
A Deus, por sua infinita misericórdia. 


\section{Agradecimentos,}

À Professora Maria Thereza Rocha de Assis Moura, pela orientação na presente dissertação de mestrado e pelas lições de vida que tem me ministrado desde o curso da Graduação;

Aos Professores Antonio Magalhães Gomes Filho e Gustavo Henrique Righi Ivahy Badaró, pelas relevantes críticas e sugestões no exame de qualificação;

Aos Professores Rogério Lauria Tucci, José Raul Gavião de Almeida e Maurício Zanoide de Moraes, pelas preciosas aulas no curso de Pós-Graduação;

Ao Professor Renato de Mello Jorge Silveira e ao Mohamad Ale Hasan Mahmoud, amigos sempre presentes;

Ao Ministro Flávio Flores da Cunha Bierrenbach, pelo exemplo de humanidade e pela incansável dedicação aos alunos e antigos alunos da Velha e Sempre Nova Academia;

À Zoé Beatriz Gonçalves de Souza e à Maria Thereza Machado Teles Walter, competentes funcionárias das bibliotecas do Superior Tribunal de Justiça e do Supremo Tribunal Federal, respectivamente, pelo fundamental auxílio;

Ao meu amado marido, Nelson Lacava Filho, pelo constante incentivo e cuidado. 
“Tudo tem o seu tempo determinado, e há tempo para todo propósito debaixo do céu: há tempo de nascer e tempo de morrer; tempo de plantar e tempo de arrancar o que se plantou; tempo de matar e tempo de curar; tempo de derribar e tempo de edificar; tempo de chorar e tempo de rir; tempo de prantear e tempo de saltar de alegria; tempo de espalhar pedras e tempo de ajuntar pedras; tempo de abraçar e tempo de afastar-se de abraçar; tempo de buscar e tempo de perder; tempo de guardar e tempo de deitar fora; tempo de rasgar e tempo de coser, tempo de estar calado e tempo de falar; tempo de amar e tempo de aborrecer; tempo de guerra e tempo de paz." (Eclesiastes 3:1-8) 


\section{Resumo}

O artigo $5^{\circ}$, inciso LXXVIII, da Constituição da República Federativa do Brasil garante a todos, no âmbito judicial e administrativo, "a razoável duração do processo". Trata-se de garantia de conteúdo vago e plurívoco, cuja eficácia depende de disciplina infraconstitucional que especifique o seu conteúdo e alcance.

Pelo princípio da reserva legal, e em decorrência do princípio da separação dos poderes, cabe ao Poder Legislativo a delimitação temporal do poder de punir do Estado, restringindo o tempo de duração da coação proveniente da tramitação do processo. Apenas na ausência de prazos legais máximos de duração do processo é que se admite a atividade interpretativa integrativa por parte do Poder Judiciário, de molde a garantir a aplicabilidade imediata da norma, que versa sobre direito fundamental.

Em auxílio a esta difícil tarefa hermenêutica, de estabelecer um marco a partir do qual não se justifica mais a continuidade do processo, porque ultrapassado o prazo razoável de sua duração, alguns critérios consagrados internacionalmente podem ser utilizados, como é o caso da complexidade da causa, comportamento das partes e conduta das autoridades responsáveis pela condução do processo.

O princípio da razoabilidade também fornece importantes subsídios para esta análise, por meio dos critérios da adequação, necessidade e proporcionalidade, ressaltando-se que deve ser empregado sempre no sentido de conferir maior proteção ao indivíduo em face do pode estatal. 


\section{Résumé}

L'article 5 inscrit dans la LXXVIII Constitution de la République Fédérative du Brésil garantit à tous, dans le domaine judiciaire et administratif, « le droit d'être jugé dans un délai raisonnable". Il s'agit d'une garantie dont le contenu est vague et équivoque à plusieurs titres et dont l'efficacité dépend d'une discipline infraconstitutionnelle qui spécifie son contenu et son étendue.

Selon le principe de réserve légale, et en conséquence du principe de séparation des pouvoirs, il appartient au Pouvoir Législatif la délimitation temporelle du pouvoir de punir de l'Etat, en limitant la durée de la contrainte émanant du cheminement du procès. C'est seulement en l'absence de délais légaux maximum de durée du procès que l'on admet l'activité interprétative intégrative de la part du Pouvoir Judiciaire, de façon à garantir l'applicabilité immédiate de la règle concernant les droits fondamentaux.

Pour aider à cette difficile tâche herméneutique, d'établir une limite à partir de laquelle ne se justifie plus la poursuite du procès, parce que le délai raisonnable de sa durée a été dépassé, certains critères reconnus internationalement peuvent être utilisés, comme c'est le cas pour la complexité de la cause, le comportement des parties et la conduite des autorités responsables de la direction du procès.

Le principe de la proportionnalité fournit également de nombreux recours pour cette analyse, par l'intermédiaire des critères de l'adéquation, de la nécessité et de la proportionnalité, soulignant que l'on doit toujours l'utiliser dans le sens d'octroyer une plus grande protection à l'individu face au pouvoir de l'état. 


\section{SUMÁRIO}

INTRODUÇÃO ....................................................................................... 10

\section{RAZÕES QUE JUSTIFICAM A LIMITAÇÃO TEMPORAL DO} PROCESSO

1.1. NECESSIDADE DE RESTRIÇÃO TEMPORAL DO EXERCÍCIO DO PODER DE PUNIR DO ESTADO - DIREITOS

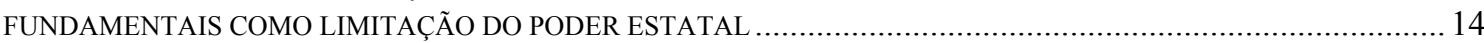

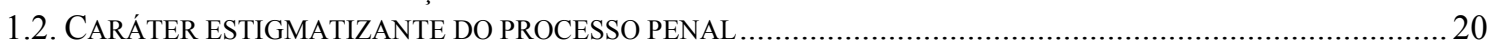

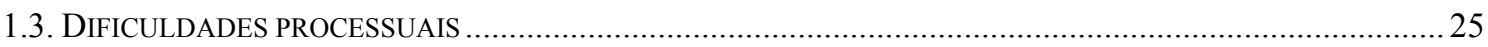

1.4. NECESSIDADE DE PROXIMIDADE DA PENA EM RELAÇÃO AO DELITO ..............................................29

1.5. PRESCRIÇÃO E DURAÇÃO DO PROCESSO: IMPOSSIBILIDADE DA PRESCRIÇÃO OPERAR COMO GARANTIA

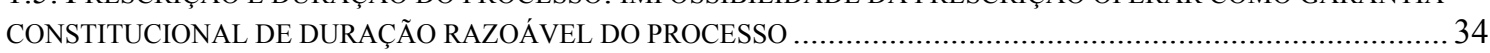

\section{GARANTIA DA RAZOÁVEL DURAÇÃO DA PERSECUÇÃo}

PENAL ............................................................................................................. 44

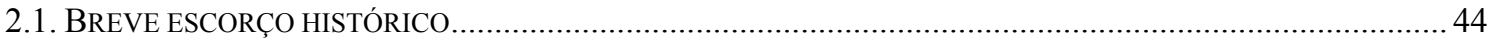

2.2. DESENVOLVIMENTO E RECONHECIMENTO NO BRASIL ................................................................ 49

\section{DIFICULDADES NA APLICAÇÃO E EFETIVAÇÃO DA GARANTIA DA RAZOÁVEL DURAÇÃO DA PERSECUÇÃO PENAL}

.

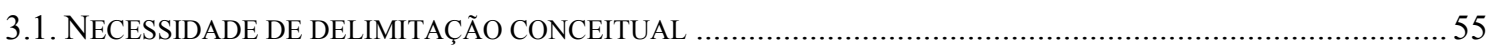

3.1.1. Risco de utilização da expressão "prazo razoável" como conceito standart ou topos jurídico .. 55

3.1.2. Risco de utilização da expressão "razoável" como mecanismo de justificação ou legitimação do excesso

\section{NOÇÃO DE RAZOABILIDADE: RECURSO AOS PRINCÍPIOS DA} PROPORCIONALIDADE E DA RAZOABILIDADE

4.1. DESENVOLVIMENTO DOS PRINCÍPIOS DA RAZOABILIDADE E DA PROPORCIONALIDADE NOS PRINCIPAIS PAÍSES

4.1.1. Alemanha

4.1.1.1. Adequação

4.1.1.2. Necessidade

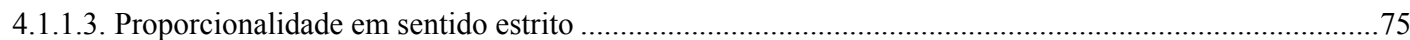

4.1.2. Inglaterra

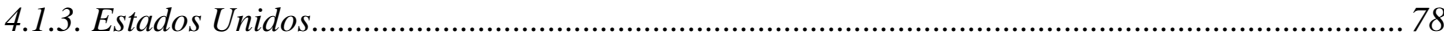

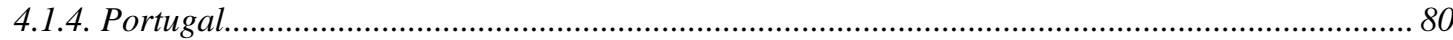

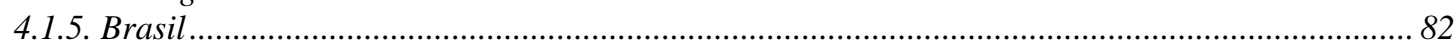

4.2. RELAÇÃO ENTRE OS PRINCÍPIOS DA RAZOABILIDADE E PROPORCIONALIDADE ..................................8 88

4.3. APLICAÇÃO DOS CRITÉRIOS DA ADEQUAÇÃO, NECESSIDADE E PROPORCIONALIDADE EM SENTIDO ESTRITO PARA A FIXAÇÃO DE UM PRAZO RAZOÁVEL DE DURAÇÃO DA PERSECUÇÃO PENAL ...........................93

5. NOÇÃO DE PRAZO: FIXAÇÃO DOS TERMOS INICIAL E FINAL PARA A CONTAGEM DO PRAZO RAZOÁVEL DE DURAÇÃO DA PERSECUÇÃO PENAL ..................................................................................97

5.1. GARANTIA DO TÉRMINO DA INVESTIGAÇÃO CRIMINAL NUM PRAZO RAZOÁVEL ....................................99 5.1.1. Marco inicial para a contagem do prazo: notitia criminis ou fixação do sujeito passivo na investigação criminal? 


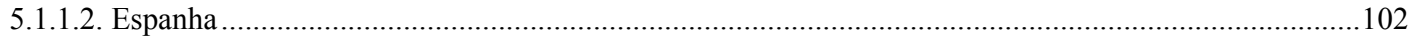

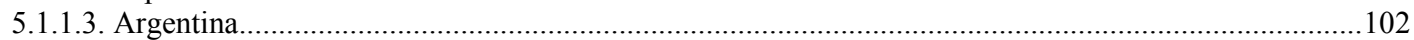

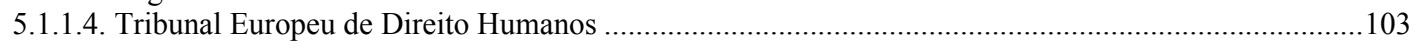

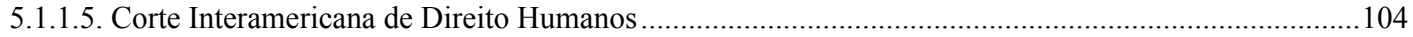

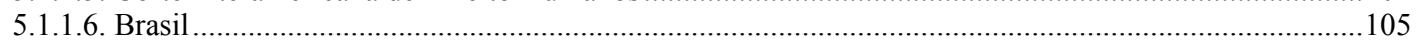

5.1.2. Marco final da contagem do prazo: conclusão da investigação ou decurso do prazo legalmente previsto?.

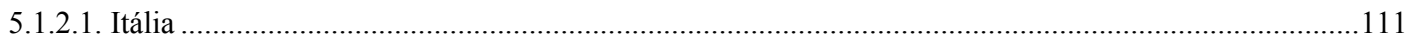

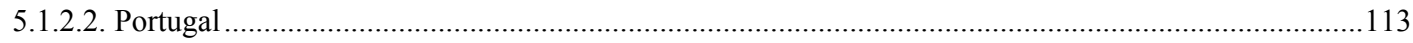

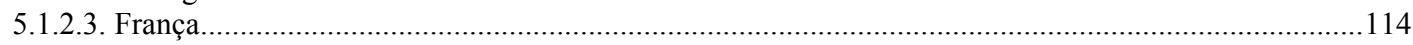

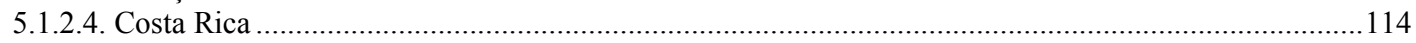

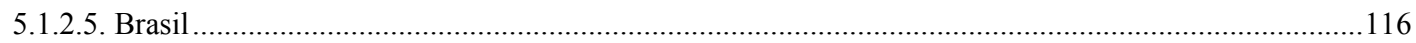

5.2. GARANTIA DO TÉRMINO DA AÇÃO PENAL DENTRO DE UM PRAZO RAZOÁVEL .................................... 120

5.2.1. Tribunal Europeu de Direitos Humanos ............................................................................. 120

5.2.2. Corte Interamericana de Direitos Humanos ....................................................................... 122

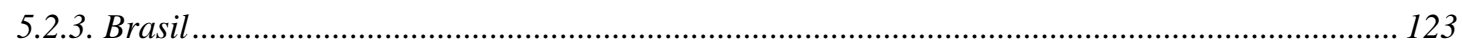

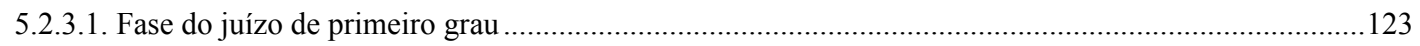

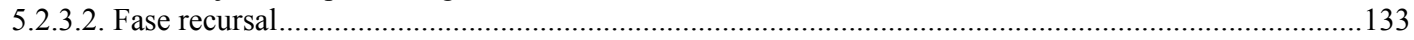

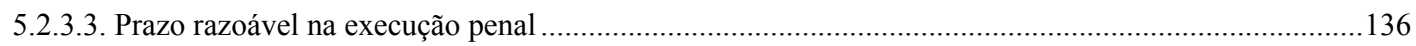

\section{CRITÉRIOS A SEREM UTILIZADOS NA FIXAÇÃO DE UM “PRAZO RAZOÁVEL DE DURAÇÃO DA PERSECUÇÃO PENAL”}

6.1. CRITÉRIOS CONSAGRADOS INTERNACIONALMENTE

6.1.1. Entendimento do Tribunal Europeu de Direitos Humanos para a aferição do prazo razoável de duração da persecução penal......

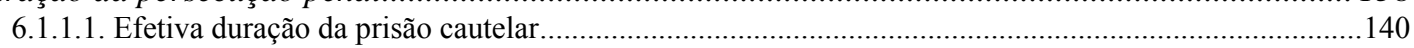

6.1.1.2. Duração da prisão cautelar em relação à pena a ser aplicada em caso de condenação ..........................142

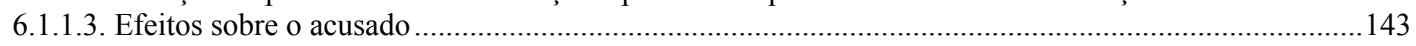

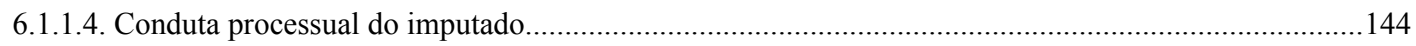

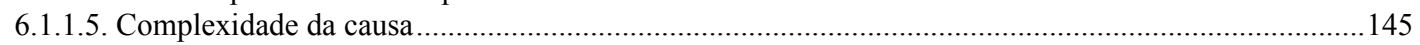

6.1.1.6. Maneira como a investigação foi conduzida e conduta das autoridades judiciais responsáveis pelo

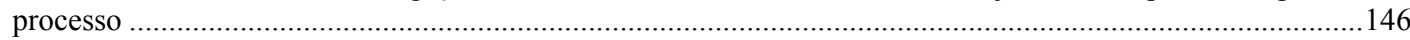

6.1.2. Entendimento da Corte Interamericana de Direitos Humanos para a aferição do prazo razoável

de duração da persecução penal ..................................................................................................... 148

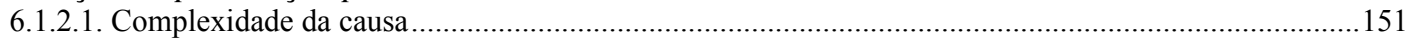

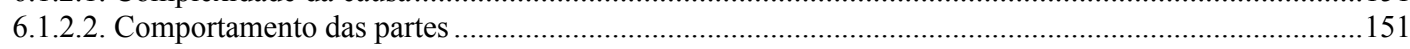

6.1.2.3. Conduta das autoridades judiciais ....................................................................................................152

6.1.3. Entendimento dos tribunais brasileiros para a aferição do prazo razoável de duração da

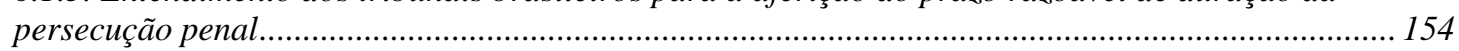

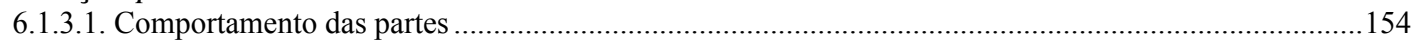

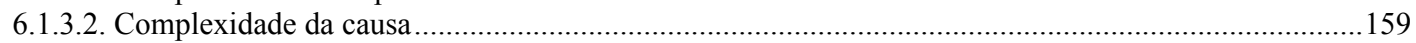

6.1.3.3. Conduta das autoridades na condução do processo ...........................................................................166

\section{CRÍTICAS À DOUTRINA DO “NÃO-PRAZO” ...................................... 169}

7.1. DA OBRIGAÇÃO DO ESTADO EM DETERMINAR LEGISLATIVAMENTE O PRAZO RAZOÁVEL DE DURAÇÃO DA

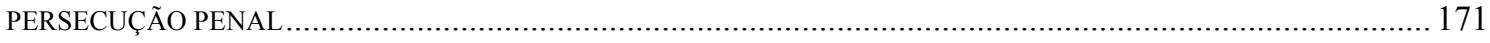

7.2. SUGESTÃo PARA A FIXAÇÃO DOS PRAZOS DE DURAÇÃO NO BRASIL ................................................... 175

7.2.1. Proposta de anteprojeto de lei .......................................................................................... 178

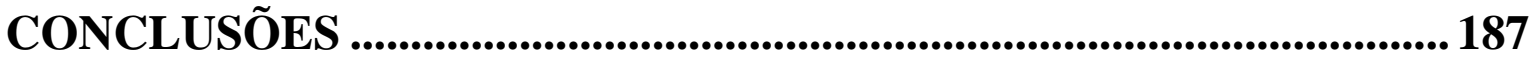

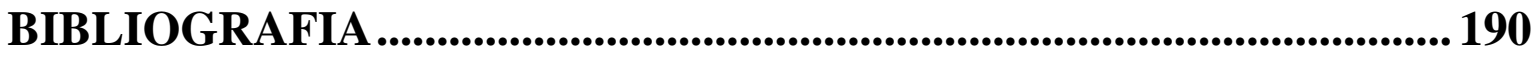




\section{INTRODUÇÃO}

A Emenda Constitucional $n^{\circ} 45$, de 8 de dezembro de 2004, ao acrescentar o inciso LXXVIII ao artigo $5^{\circ}$ da Constituição da República, que passa a assegurar a todos, no âmbito judicial e administrativo, a razoável duração do processo e os meios que garantam a celeridade de sua tramitação, imediatamente trouxe para o debate acadêmico o questionamento sobre qual teria sido o efeito da inserção de tal dispositivo no ordenamento jurídico brasileiro.

A previsão de um prazo razoável de duração para a persecução penal já constava de tratados internacionais ratificados pelo Brasil, entre eles, em especial, do Pacto de São José da Costa Rica. Da mesma forma, entre os doutrinadores, era corrente a afirmação de que referida garantia, embora não constasse do texto expresso da Constituição, decorria naturalmente de outras garantias, do devido processo legal e do acesso à justiça. Além do que, a própria determinação constitucional do $\S 2^{\circ}$ do $\operatorname{artigo~} 5^{\circ}$, segundo a qual "os direitos e garantias expressos nesta Constituição não excluem outros decorrentes do regime e dos princípios por ela adotados, ou dos tratados internacionais em que a República Federativa do Brasil seja parte”, permitia afirmar com segurança que a garantia do prazo razoável para a duração do processo integrava o sistema de garantias constitucionais mesmo antes da Emenda $n^{\circ} 45$.

Assim, os questionamentos que se seguem à Emenda $n^{\circ} 45$ são imediatos: qual foi o efeito trazido por tal norma, tanto na doutrina quanto na jurisprudência, e que colaboração trouxe este dispositivo para o contexto da efetividade da garantia?

Sendo este o tema que se coloca, pretendeu o presente trabalho enfocar a garantia em questão atendendo-se aos seguintes passos: (i) estudo da razão pela qual se justifica a existência de uma garantia com este conteúdo; (ii) análise do contexto de criação da norma e os efeitos na doutrina e na jurisprudência, bem como a constatação do problema-central da dissertação, que é a falta de limite legal para a aferição do excesso de prazo, assim como os riscos para a eficácia da garantia para a proteção dos direitos fundamentais do homem; (iii) a pesquisa de parâmetros e critérios interpretativos que podem auxiliar o juiz na fixação do prazo razoável de duração do processo a partir do qual o poder não mais se legitima e a constatação de que o seu grau de subjetividade pode 
esvaziar o conteúdo da garantia; (iv) crítica à inexistência de prazos legais para o término do processo, e sugestão de anteprojeto de lei nesse sentido.

O tema da demora na prestação jurisdicional, em especial no âmbito do processo penal, sempre esteve presente como fator de preocupação constante dos doutrinadores e juízes, desde o momento em que o Estado adotou para si a exclusividade no exercício do poder punitivo, dado que a incerteza sobre o destino do indivíduo, máxime quando este se encontra encarcerado no curso do processo, afronta a própria noção de justiça.

Não apenas sob o aspecto jusfundamental, pelo qual se impõe uma delimitação no âmbito de restrição por parte do Estado, existem fundamentos outros para a necessidade de fixação de um prazo razoável de duração do processo. Do ponto de vista dos fins da pena, a demora na imposição da sanção importa em sua menor eficácia, sendo certo que quanto mais pronta for a resposta estatal, maior será o efeito preventivo desta, seja para a inibição do cometimento de novos crimes pela sociedade (prevenção geral negativa), seja para a reafirmação dos valores sociais vigentes e proteção do próprio sistema normativo (prevenção geral positiva). Criminologicamente, também se mostra relevante a persecução penal célere, dado que o processo penal detém um caráter estigmatizante em si mesmo, sendo que a demora do próprio procedimento pode inverter o conteúdo do princípio da presunção de inocência, eternizando a desconfiança deletéria da sociedade em relação à culpa do indivíduo, trazendo insuportáveis ônus ao sujeito que se submete à acusação estatal.

Por esta razão, deve haver um controle da duração do processo, não só de modo a fazer saber ao acusado o limite máximo do tempo de restrição por parte do Estado em sua vida e liberdade, o que constitui um direito público subjetivo, mas também para assinalar à própria sociedade a legitimidade da interferência estatal sobre a esfera de direitos daquele indivíduo e propiciar o aumento da confiança no respeito dos direitos fundamentais e no exercício do devido processo legal, que é conquista de toda a sociedade.

As principais limitações do tema da garantia razoável duração do processo residem na própria estrutura vaga da noção do que seja razoável. Não existindo na lei prazos globais para a duração do processo e não havendo nem mesmo a fixação de alguns parâmetros legais que possam auxiliar na compreensão do conceito, a aplicação da garantia perde muito de sua força na verificação do excesso temporal do poder estatal na condução do processo. 
A partir de uma análise da jurisprudência, verifica-se que, em não poucas ocasiões, a noção de razoabilidade é utilizada como um mecanismo de justificação do excesso, e não de sua vedação. Diante da natureza fluida do conceito, acaba-se por, mesmo diante de uma extrapolação irrazoável dos prazos processuais, utilizar a própria idéia de razoabilidade como parte de um mecanismo argumentativo para legitimar ad posteriori a demora no desenrolar do procedimento, especialmente em casos em que desponta a gravidade em concreto do crime. Utiliza-se, assim, uma garantia criada em prol do indivíduo, como proteção da pessoa em relação ao poder estatal, para, ao contrário, buscar justificação em nome da proteção da coletividade.

Além da dificuldade em relação à idéia de "razoabilidade", há incerteza no tocante ao próprio alcance da garantia da duração do processo, especialmente a partir de que momento se inicia a contagem do prazo e até quando se encerra, diante das dificuldades inerentes tanto ao sistema de investigação preliminar quanto ao grau de incriminação nesta fase e do próprio sistema de recursos, que envolve questões de difícil abordagem, como a da execução provisória da pena e a inexistência de efeito suspensivo dos recursos extraordinários.

O intuito da presente dissertação de mestrado foi, portanto, a pesquisa voltada ao estudo de alguns critérios ou parâmetros utilizados pelos juízes para a verificação do excesso de prazo, em cada caso concreto, de modo a tornar o conceito de razoável duração do processo menos vago, colaborando, assim, para um maior efetividade da garantia constitucional.

Para isso, o estudo do princípio da razoabilidade fornece alguns critérios úteis, especialmente levando-se em consideração as idéias de adequação, necessidade, proporcionalidade e de legalidade, além dos critérios já delimitados, no âmbito internacional, pelas Cortes de Direitos Humanos, que, sem dúvida, fornecem alguns elementos de inquestionável utilidade prática, mas que certamente ainda precisam de maior delimitação.

Não se pretendeu abordar os meios pelos quais deverá ser garantida a celeridade da tramitação dos processos, por demandar pesquisa do tipo empírica que extrapola os limites deste trabalho, já que estes vão desde a necessidade de se barrar o processo de expansão do Direito Penal, até a completa reestruturação do Poder Judiciário. Do mesmo modo, não serão abordados os tipos de sanção possíveis para o descumprimento da garantia, assumindo-se a postura de que apenas uma sanção extintiva processual pode 
conferir-lhe eficácia, já que outras sanções compensatórias ou que incidem sobre a pena eventualmente aplicada, incidem quando já ocorrida a violação.

Tampouco se procurou tratar do direito do acusado a ser posto em liberdade, excedido o prazo de duração da prisão, por caracterizar, igualmente, abordagem distinta da que se propôs seguir. 


\section{RAZÕES QUE JUSTIFICAM A LIMITAÇÃO TEMPORAL DO PROCESSO}

Numa sociedade em que a economia de tempo e encurtamento das distâncias é a principal tônica, e coexistência com uma Justiça lenta traz angústia e a sensação de insegurança.

Especialmente quando se trata de processo de natureza criminal, a demora da prestação jurisdicional colabora tanto para que o acusado seja lesado em seu direito fundamental a ser julgado dentro de um prazo razoável, ficando sujeito a restrições em seus direitos fundamentais por tempo indeterminado, quanto para que a sociedade alimente a sensação de insegurança e de impunidade.

Cada vez mais se torna evidente este desequilíbrio intransponível entre a velocidade social e a velocidade judicial. É o tempo da Internet, dos negócios, do mundo globalizado, encontrando barreiras no direito vagaroso, arcaico.

\subsection{Necessidade de restrição temporal do exercício do poder de punir do Estado - direitos fundamentais como limitação do poder estatal}

A idéia de limitação do poder do Estado surge no Iluminismo a partir da idéias contratualistas, que se postavam antagonicamente à figura do Estado absolutista. Há de se ter em mente que, no momento em que foram desenvolvidas estas teorias, os estudiosos se pautavam por uma concepção de Direito em que a lei escrita não tinha grande valor e que se primava pelo direito natural de matriz metafísica. Os filósofos do Iluminismo inseriram no Direito a idéia de respeito à razão, o que permanece até hoje.

Tanto na perspectiva de LOCKE, quanto na de HOBBES e de ROUSSEAU, três dos principais teóricos do Iluminismo, os poderes do Estado criado a partir do contrato social não são ilimitados, mas devem, ao contrário, encontrar uma limitação clara no próprio pacto que o originou.

Para LOCKE, por exemplo, é possível viver no estado de natureza, sem o Estado, mas a criação de um governo civil é benéfica, adequada para aperfeiçoar a 
convivência entre as pessoas, porque impõe alguns limites, especialmente com relação ao direito de propriedade ${ }^{1}$.

Uma vez criado o Estado pelo consenso entre os homens de uma determinada sociedade, os seus próprios poderes devem ser limitados, não podendo ultrapassar e desrespeitar os mesmos direitos que os homens já possuíam em seu estado de natureza $^{2}$. Se o Estado foi criado precisamente para assegurar e potencializar o exercício dos direitos que os homens gozavam no estado de natureza, não haveria sentido em permitir a violação destes mesmos direitos pelo Estado. Aqui, portanto, o limite do Estado reside no respeito aos direitos naturais do homem.

Já para HOBBES, não é possível viver em sociedade num estado natural, já que o ser humano é incapaz de assegurar a sua preservação. Para ele, "se não for instituído um poder suficientemente grande para nossa segurança, cada um confiará, e poderá legitimamente confiar, apenas em sua própria força e capacidade, como proteção contra todos os outros",

Todavia, a mesma idéia de limitação existe também para este autor: o poder do Estado não pode alcançar aqueles direitos que não podem ser transferidos por meio de um pacto, tais como o direito de não se abster de se defender, o de não se auto-mutilar, o de não se matar, o de respirar e se alimentar, etc $^{4}$. São, portanto, certos direitos inerentes à própria existência do homem, fatores de limitação do poder absoluto do Estado em ditar as leis civis.

Para ROUSSEAU, igualmente, o ser humano em estado de natureza depende de suas forças para ser livre ${ }^{5}$. Por meio de uma disputa de forças, o mais forte consegue sempre escravizar os mais fracos, a não ser que todos individualmente resolvam abrir mão de sua liberdade natural e escolham eleger um Estado que imprima sua força

\footnotetext{
${ }^{1}$ John Locke, Segundo Tratado sobre o governo civil: ensaio sobre a origem, os limites e os fins verdadeiros do governo civil, traduzido por Magda Lopes e Marisa Lobo da Costa, Petrópolis, Vozes, 1994, pp. 82 e 156.

${ }^{2}$ Idem, p. 164.

${ }^{3}$ Thomas Hobbes de Malmesbury, Leviatã ou Matéria, Forma e Poder de um Estado Eclesiástico e Civil, tradução de João Paulo Monteiro e Maria Beatriz Nizza da Silva, São Paulo, Nova Cultural, 1999, p. 141.

${ }^{4}$ Idem, p. 175.

${ }^{5}$ Jean-Jacques Rousseau, O contrato social e outros escritos, São Paulo, Cultrix, 1971, pp. 29-31.
} 
para proteger os seus direitos, o que caracteriza a chamada liberdade civil ${ }^{6}$. Assim, "o pacto fundamental, ao invés de destruir a igualdade natural, substitui, ao contrário, por uma igualdade moral e legítima, a desigualdade que a Natureza pôde por entre os homens, fazendo com que estes, conquanto possam ser desiguais em força ou em talento, se tornam iguais por convenção e por direito" 7 .

O poder do soberano deve, para ROUSSEAU, ficar restrito à vontade geral, da população, expressa por meio das leis, às quais ele mesmo está sujeito. A vontade individual do governante não pode ser colocada à frente das leis, sob pena de enfraquecimento e destruição do Estado, mas, ao contrário, este deve respeitar a vontade geral, que é a reunião de todas as vontades ${ }^{8}$.

Trata-se, portanto, neste primeiro momento, de uma restrição de caráter qualitativo, em que são elencadas algumas matérias ou assuntos que não podem ser ignorados pelo Estado, servindo de limitação de seu poder.

Delineamos, neste ponto, as principais idéias do que $\mathrm{BOBBIO}^{9}$ denomina "democracia dos antigos", que se contrapõe à idéia de limitação do poder denominada "democracia dos modernos", cujo conceito passaremos a discorrer.

Em decorrência do Iluminismo, tornou-se propícia uma modificação nas estruturas sociais e políticas do mundo, que foram marcadas principalmente pela Revolução Francesa de 1789 e a Independência dos Estados Unidos em 1776.

Estes acontecimentos históricos vieram acompanhados da elaboração de documentos que reconheciam direitos inerentes à pessoa humana, respectivamente a Declaração dos Direitos do Homem e do Cidadão, de 1789, na França, assim como, nos Estados Unidos, da Declaração de Independência, de 4 de julho 1776, a Declaração de Direitos da Virgínia, em 1787 e o Bill of Rights de 25 de setembro de 1789, que constitui a

\footnotetext{
${ }^{6}$ Idem, p. 34: "O que o homem perde pelo contrato social é a liberdade natural e um direito ilimitado a tudo o que tenta e pode alcançar; o que ganha é a liberdade civil e a propriedade de tudo o que possui. Para que não haja engano em suas compensações, é necessário distinguir a liberdade natural, limitada pelas forças do indivíduo, da liberdade civil que é limitada pela liberdade geral, e a posse, que não é senão o efeito da força ou do direito do primeiro ocupante, da propriedade, que só pode ser baseada num título positivo".
}

${ }^{7}$ Idem, p. 37.

8 “Quem redige as leis não tem, portanto, ou não deve ter nenhum direito legislativo, e o próprio povo não pode, mesmo se o quisesse, despojar-se desse incomunicável direito, porque, de acordo com o pacto fundamental, a vontade geral é a única que obriga os particulares, e nunca se pode afirmar que uma vontade particular está conforme a vontade geral, senão depois de havê-la submetido aos livres sufrágios do povo" (Idem, p. 51).

${ }^{9}$ Norberto Bobbio, A Era dos Direitos, Trad. Regina Lyra, Rio de Janeiro, Elsevier, 2004, p. 227. 
Carta de Direitos Fundamentais Americana, expressa nas dez primeiras Emendas à sua Constituição. Iniciou-se, assim, um movimento constitucionalista, que propiciou a construção do modelo de Estado denominado "Estado de Direito".

No âmbito do sistema romano-germânico, em decorrência da idéia de limitação do poder do Estado sobre o direito de liberdade e da propriedade dos indivíduos, surge o apego à lei escrita como "Direito Posto". O Direito passa ser, sob esta perspectiva, o que a lei diz que é ${ }^{10}$.

O Estado liberal assim constituído faliu com a percepção de que deveriam ser reconhecidos direitos sociais aos seres humanos, haja vista a miséria e a pobreza que marcaram as periferias das cidades por conta do capitalismo adotado como sistema econômico ${ }^{11}$. Importante ressaltar que, em razão desse modelo de Estado, deflagrou-se a primeira Guerra Mundial, que se deu em razão da luta pela conquista de colônias que serviriam para propiciar matérias primas que alimentariam as indústrias das potências européias.

Em resposta a este anseio pelo reconhecimento de direitos sociais aos trabalhadores, surgem documentos como a Constituição Mexicana, de 1917, e a Constituição Alemã de Weimar, de 1919, que instituíram um novo modelo de Estado denominado Estado Social, como contra-propaganda, de certa forma, da Revolução Comunista de 1917.

Esse modelo de Estado teve desaparecimento repentino, visto que foi distorcido e, na Alemanha, possibilitou o desenvolvimento da doutrina nacional socialista, que culminou com o surgimento do nazismo e, a assunção de Hitler como Füher do Estado alemão.

Por apego extremado à idéia formal da lei, como decorrente da vontade popular da maioria, e a visão de que o Estado deveria intervir de maneira significativa na liberdade dos indivíduos a fim de fomentar os direitos sociais, abriu-se perigoso espaço à violação sistemática de direitos humanos, considerados pelos clássicos como direitos naturais, como se pôde observar com o fascismo na Itália, o franquismo na Espanha e o

\footnotetext{
${ }^{10}$ Tércio Sampaio Ferraz Jr., Introdução ao estudo do Direito - técnica, decisão, dominação, $2^{\mathrm{a}}$ ed., Atlas, São Paulo, 1994, p. 74.

${ }^{11}$ Antonio Enrique Pérez Luño, Derechos Humanos, Estado de Derecho y Constitución, $8^{\mathrm{a}}$ ed., Madrid, Tecnos, 2003, p. 220.
} 
nazismo na Alemanha, a título de exemplo ${ }^{12}$. Estes regimes totalitários deram ensejo à $2^{\mathrm{a}}$ Gerra Mundial e aos horrores do holocausto.

Após a Segunda Guerra Mundial, percebeu-se que não mais seria admissível que o Direito estivesse desvinculado de um mínimo conteúdo ético. Observouse, a partir da Declaração Universal dos Direitos Humanos, de 18 de junho de 1948, um fenômenos denominado de "positivação dos direitos humanos" que, após reconhecidos no âmbito internacional, passaram a fazer parte dos textos constitucionais dos diversos Estados, sendo, assim, denominados "direitos fundamentais" $"$.

Cunhou-se a idéia de que, para preservar a democracia, a segurança e a paz, seria necessário que os Estados garantissem um mínimo de direitos, inerentes ao respeito à dignidade da pessoa humana. Assim, os direitos fundamentais e suas garantias, como afirma FERRAJOLI, possibilitam, acima de tudo, o pleno exercício do princípio democrático, pois implementam a igualdade material entre todos os indivíduos ${ }^{14}$.

A partir dessa idéia é que surge o modelo denominado Estado Democrático de Direito, fundado na dignidade da pessoa humana e no pluralismo político, que passa a ser admitido pelas Constituições de diversos países do mundo, como Alemanha, França, Espanha, Brasil, etc.

Nesse modelo de Estado, as decisões políticas não se legitimam caso contrariem os direitos fundamentais.

Os direitos fundamentais trazem em seu bojo, na lição de MORAES, três características dos direitos humanos, quais sejam, a universalidade, a interdependência e a inter-relação. Já, como conseqüência de sua positivação, surge como uma quarta característica a irrevogabilidade $^{15}$. Ou seja, pela característica da universalidade, garante-

\footnotetext{
${ }^{12}$ Idem, p. 229.

13 Maurício Zanoide de Moraes afirma que os direitos fundamentais seriam o conjunto de direitos que constituem "a essência do que um indivíduo deve ter respeitado para ter sua dignidade plena, tal qual os direitos humanos historicamente formados, reconhecidos e garantidos em nível internacional", diferenciandose destes, somente pelo fato de serem positivados em nível constitucional (Maurício Zanoide de Moraes, Presunção de inocência no processo penal brasileiro: análise de sua estrutura normativa para a elaboração legislativa e para a decisão judicial, Tese de livre-docência apresentada à Faculdade de Direito da Universidade de São Paulo, São Paulo, 2008, p. 241).

${ }^{14}$ Luigi Ferrajoli, Diritto e ragione: teoria del garantismo penale, $7^{\mathrm{a}}$ ed., Roma, Laterza, 2002, pp. 947-967.

" In tutti i casi $i$ diritti fondamentali compondono a valori e a bisgni vitale della persona storicamente $e$ culturalmente determinati. Ed é dalla loro qualitá, quantitá e grado di garanzia Che puó essere definita la qualitá di uma democrazia e puó essere minsurato il progresso"(op. cit. p. 958).

${ }^{15}$ Maurício Zanoide de Moraes, op. cit., Idem, p. 242.
} 
se que, em regra, e a princípio, todos sejam titulares de qualquer direito fundamental; pela característica da irrevogabilidade, que só é admissível a sua expansão e nunca a sua supressão ou redução ${ }^{16}$; e, pela característica da complementaridade ou interdependência, impede-se que sejam vistos de maneira estanque, devendo sempre a interpretação de seu conteúdo impedir que sejam vistos como uma sucessão de direitos, mas como direitos que se conjugam e interpenetram com os novos e com os que ainda estão por vir ${ }^{17}$.

No Brasil, a partir do processo de redemocratização, que se deu a partir de 1985, nota-se uma preocupação constante em se introduzir no ordenamento jurídico os direitos humanos, sendo digna de nota a inserção no $\S 2^{\circ}$ do artigo $5^{\circ}$ da Constituição de 1988, que dispõe: “os direitos e garantias expressos nessa Constituição não excluem outros decorrentes do regime e dos princípios por ela adotados, ou dos tratados internacionais em que a República Federativa do Brasil seja parte" ${ }^{18}$.

FERRAZ JR. alerta para o perigo de uma possível banalização dos direitos humanos que surgiriam em decorrência de sua própria positivação e de um "processo de multiplicação (de direitos de primeira, segunda, terceira, quarta e não sei quantas mais gerações)" ${ }^{\prime 19}$. O mesmo autor afirma, ainda, que a idéia segundo a qual "toda declaração de ‘direitos do homem' é inseparável de sua garantia” traz duas ordens de problemas de difícil resolução: o primeiro diz respeito ao fato de serem limitações ao Estado (garantias contra o poder estatal) e terceiros a serem limitadas pelo próprio Estado; o segundo de que "o homem é o transformador das estruturas do mundo e o mundo é uma estrutura planificada que inclui o próprio homem" 20 .

A inserção da garantia da razoável duração do processo como limitação temporal do poder do Estado pela Emenda Constitucional no 45 e pelo Decreto-lei $n^{\circ} 27$, de

\footnotetext{
${ }^{16}$ É o que se infere do artigo $60, \S 4^{\circ}$, inciso IV, da Constituição da Republica, que proíbe Emendas Constitucionais tendentes a suprimir ou restringir direitos fundamentais.

${ }^{17}$ Maurício Zanoide de Moraes, op. cit., pp.. 343-346.

${ }^{18}$ Nesse sentido, ver Flávia Piovesan, Direitos Humanos e o Direito Constitucional Internacional, $7^{\mathrm{a}}$ ed., São Paulo, Saraiva, 2006, p. 255.

19 Tércio Sampaio Ferraz Jr., Direito Constitucional: liberdade de fumar, privacidade, estado, direitos humanos e outros temas, Barueri, Manole, 2007, p. 517.

${ }^{20}$ Idem, p. 527.
} 
26 de maio de 1992, que assegurou vigência interna ao Pacto de São José da Costa Rica, enquadra-se nesse contexto de positivação dos direitos fundamentais ${ }^{21}$.

Da garantia da razoável duração do processo depende a própria efetivação de outras garantias fundamentais, dado que um processo seja demasiado célere, seja demasiado lento, acaba por subverter outras garantias constitucionais, tais como a ampla defesa, o contraditório e a presunção de inocência.

Sob esta perspectiva, uma restrição apenas qualitativa ou material do poder do Estado não é suficiente. O poder de coação do indivíduo por meio do processo se justifica e se legitima para a apuração de um delito, mas ao se prolongar no tempo, transmuda-se em ilegítimo, porque atinge a dignidade da pessoa humana.

O tema da duração do processo, por exemplo, de que se ocupa o presente estudo, demonstra que o direito de punir do Estado autoriza uma restrição aos direitos do acusado durante a persecução penal, seja do direito à liberdade, à propriedade, e à intimidade. Todavia, esta restrição só é aceitável se dotada de provisoriedade, ou seja, o indivíduo não pode ficar à mercê do Estado por tempo indeterminado, pois toda restrição a direitos fundamentais tem de ser prevista em lei e ter tempo determinado de duração.

Percebe-se, assim, que a limitação do poder do Estado ultrapassa uma perspectiva meramente qualitativa ou material, para englobar também um aspecto quantitativo ou temporal.

Essa necessidade de restrição temporal ao exercício do poder de punir do Estado, garantindo o direito do indivíduo de receber uma resposta do Estado em tempo oportuno, com o menor âmbito de restrição possível a sua esfera de direitos, portanto, fundamenta a existência de um direito a que a persecução penal se dê dentro de um prazo razoável de duração, uma vez que o indivíduo não pode aceitar uma limitação eterna à sua esfera de direitos em nome da necessidade de apuração de um crime ou, ainda, da busca da verdade real.

\subsection{Caráter estigmatizante do processo penal}

${ }^{21}$ Ver a forma como se deu o processo de positivação da garantia da razoável duração do processo no capítulo 2 , infra. 
Não há dúvida de que, a despeito do princípio da presunção de inocência, o próprio processo antecipa parte dos efeitos da pena. CARNELUTTI já apontava o processo como pena, equiparável à tortura: “(...) mas o processo por si mesmo é uma tortura. Até certo ponto, dizia, não se pode fazer por menos; mas a assim chamada civilização moderna tem exasperado de modo inverossímil e insuportável esta triste conseqüência do processo. O homem, quando é suspeito de um delito, é jogado às feras. A fera, a indomável e insaciável fera, é a multidão. $O$ artigo da Constituição, que se ilude de garantir a incolumidade do acusado, é praticamente inconciliável com aquele outro que sanciona a liberdade de imprensa. Logo que surge o suspeito, o acusado, a sua família, a sua casa, o eu trabalho são inquiridos, investigados, despidos na presença de todos. O indivíduo, assim, é feito em pedaços. E o indivíduo, assim, relembremo-nos, é o único valor da civilização que deveria ser protegido" 22 .

O reconhecimento de que o processo penal apresenta um caráter estigmatizante em relação ao acusado, sem dúvida possibilita uma compreensão mais completa sobre a necessidade de limitação temporal do processo, bem assim, da razão de ser da garantia da razoável duração do processo.

De acordo com LOPES JR., o processo somente pode durar um tempo que se mostre razoável, tolerável, porque, extrapolado esse prazo, ocorre uma verdadeira usurpação pelo Estado do tempo que pertencia legitimamente ao particular: "Como veremos, quando a duração de um processo supera o limite da duração razoável, novamente o Estado se apossa ilegalmente do tempo do particular, de forma dolorosa e irreversível. E esse apossamento ilegal ocorre ainda que não exista uma prisão cautelar, pois o processo em si mesmo é uma pena". ${ }^{23}$

Assim, quando o Estado se apossa do tempo do particular, isto não deixa de significar uma sanção em si mesma. Tanto para o réu preso como para o réu solto, o tempo do processo se mostra punitivo e doloroso.

O direito espanhol identifica este apenamento como sendo uma pena de banquillo, ou seja, é aquela pena do mero "estar no banco dos réus"24. O estigma social

\footnotetext{
${ }^{22}$ Francesco Carnelutti, As misérias do processo penal, tradução de José Antonio Cardinalli, São Paulo, Conan, 1995, p. 46.

23 Aury Lopes Jr., "O tempo como pena processual: em busca do direito de ser julgado em um prazo razoável", in Andrei Zenkner Schmidt (coord.), Novos rumos do Direito Penal contemporâneo - livro em homenagem ao prof. Dr. Cezar Roberto Bitencourt, Rio de Janeiro, Lumen Juris, 2006, p. 198.

24 “Ilustrativa é a expressão 'pena de banquillo', consagrada no sistema espanhol, para designar a pena processual que encerra o 'sentar-se no banco dos réus'. É uma pena autônoma, que cobra um alto preço por si
} 
que decorre do simples fato de responder a um processo criminal é por demais evidente, restando claro em muitas ocasiões do cotidiano, desde o momento em que o empregador exige a certidão de distribuição do fórum para verificar se o futuro empregado responde ou não a um processo criminal, até a exigência feita em muitos concursos públicos de que o candidato não responda, ou até mesmo que nunca tenha respondido, a qualquer processo criminal.

Há, ademais, com o prolongamento do processo, uma maior estigmatização do indivíduo. Quanto mais tempo durar o processo, com toda sua ritualística degradante, mais será o estigma social suportado pelo acusado.

A problemática da estigmatização do indivíduo pelas instâncias formais de controle, incluindo o processo penal, foi bem desenvolvida no âmbito da Criminologia crítica a partir dos anos sessenta, especialmente pela teoria do labelling approach.

De acordo com esta teoria, a criminalidade secundária é resultado de um processo de estigmatização do indivíduo, o resultado de uma reação social, mais do que uma qualidade interna a ele $^{25}$. Não se trata de determinismo, mas de estudo realizado a partir de uma perspectiva interacionista.

Embora não explique de maneira satisfatória como se dá a criminalidade primária $^{26}$, o labelling approach teve um importante papel para a compreensão de que a maneira de atuação das instâncias formais de controle pode ter influência sobre o indivíduo, contribuindo para que este venha a prosseguir ou iniciar-se em uma carreira criminosa $^{27}$, à medida em que este passa a ser visto perante a sociedade como efetivamente um delinqüente.

Trata-se, nos termos criados pela teoria criminal em questão, de "uma profecia que se cumpre a si mesma": tratar uma pessoa como um delinqüente, pode colaborar para que ela passe a se conformar e a corresponder à imagem que a sociedade faz dela. Isto porque a estigmatização da pessoa provoca, antes de mais nada, um afastamento

\footnotetext{
mesma, independentemente de futura pena privativa de liberdade (que não compensa nem justifica, senão que acresce o caráter punitivo de todo o ritual judiciário)" (Aury Lopes Jr., "O tempo como pena processual...", cit., p. 199, na nota de rodapé $\left.\mathrm{n}^{\circ} 19\right)$.

${ }^{25}$ Cf. Jorge de Figueiredo Dias e Manuel da Costa Andrade, Criminologia: o homem delinqüente e a sociedade criminógena, 2a reimpressão, Coimbra, Coimbra Editora, 1997, p. 49.

${ }^{26}$ Idem, p. 161.

${ }^{27}$ Por assim dizer, a teoria do labelling approach "alarga o elenco das personagens responsáveis pelo crime, elevando à categoria de 'factores' criminógenos as instâncias formais de controlo" (Idem, ibidem).
} 
social, estreitando a sua margem de oportunidades legítimas. A falta de apoio e solidariedade por parte da sociedade, por outro lado, pode ser compensada pela associação com outras pessoas marginalizadas na busca de outras oportunidades, representando, assim, um estímulo perigoso ao cometimento de crimes (criminalidade secundária) ${ }^{28}$.

Da mesma forma, a própria ação judicial tem efeitos sobre a chamada criminalidade secundária. Todo o ritual por que passa o acusado, especialmente quando responde ao processo preso, colabora para uma estigmatização social que não é apagada nem mesmo com a absolvição. Nas palavras de Figueiredo Dias e Manuel da Costa Andrade, "não é, na verdade, indiferente, do ponto de vista da preparação da defesa e do afrontamento do ritual tendencialmente degradante do julgamento, entrar na sala de audiência como detido, acompanhado de autoridades policiais de postura mais ou menos militarizadas e, nesta veste, entrar e sair da sala quantas vezes a audiência for interrompida e retomada. Mesmo que a absolvição venha, afinal, a ocorrer, a verdade é que já ninguém poupará ao ex-argüido os custos do estigma duma prisão"29.

Quanto mais tempo restar o acusado sob o peso de uma acusação criminal, maiores serão os prejuízos pessoais suportados por ele. Isto porque "especialmente no processo penal, o tempo é o verdadeiro significante da punição, não só na pena privativa de liberdade, mas também na prisão cautelar e, principalmente, no simples fato de 'estar sendo processado" "30 . De acordo com MESSUTI, a pena consiste justamente na utilização do tempo pelo direito para alcançar os fins que almeja ${ }^{31}$.

"Não há dúvida de que tanto maior será o estigma, quanto maior for a duração do processo penal, especialmente se o acusado estiver submetido a medidas cautelares" ${ }^{\prime 2}$. Uma vez absolvido o acusado que esteve submetido a prisão cautelar decretada no curso do processo, concretiza-se uma situação de dano (moral e material) de

\footnotetext{
${ }^{28}$ Ver, a respeito, a obra de Jorge de Figueiredo Dias e Manuel da Costa Andrade, op. cit., pp. 352-353.

${ }^{29}$ Idem, p. 502.

${ }^{30}$ Aury Lopes Jr. e Gustavo Henrique Righi Ivahy Badaró, Direito ao processo penal no prazo razoável, Rio de Janeiro, Lumen Juris, Rio de Janeiro, 2006, p. ix.

${ }^{31}$ Ana Messuti, O tempo como pena, Trad. Tadeu Antonio Dix Silva, Maria Clara Veronesi de Toledo, São Paulo, Revista dos Tribunais, 2003, p. 42.

${ }^{32}$ Aury Lopes Jr., "O tempo como pena processual...”, cit., p. 199, na nota de rodapé nº 20.
} 
impossível reparação, sendo possível apenas a sua indenização, conforme a própria Constituição determina, em seu artigo $5^{\circ}$, inciso $\mathrm{LXXV}^{33}$.

Ainda, a demora do processo pode trazer efeitos negativos sobre o próprio convencimento judicial. Como bem destacado por CAFFERATA NORES, a Comissão Interamericana dos Direitos Humanos aponta, como um dos fundamentos da razoável duração do processo, o aumento do risco de se inverter o sentido da presunção de inocência com o passar do tempo, sendo que a prolongada duração da prisão provisória aumenta consideravelmente a possibilidade de ser destinada ao acusado uma pena prolongada, que legitime o encarceramento prévio $^{34}$.

Neste mesmo sentido, destaca FIGUEIREDO DIAS e COSTA ANDRADE que as decisões sobre a prisão preventiva e a sua manutenção, assim como a determinação de outras medidas restritivas, como busca e apreensão e interceptação telefônica, valem por si sós como uma forma de seleção, sendo que "elas podem repercutir decisivamente na conformação posterior do processo e no seu out-put final, em termos de condenação ou absolvição, ou de sanção mais ou menos drástica",35.

Mesmo com relação ao indivíduo solto, é fácil constatar que a demora na solução do processo acaba eternizando a desconfiança popular sobre a sua inocência, enfraquecendo-se com o decorrer do tempo a própria garantia da presunção de inocência, pois a sociedade começa a acreditar verdadeiramente na culpa da pessoa envolvida, mesmo que ao final venha a ser absolvida. Como bem ressaltado por ZANOIDE DE MORAES, "a presunção de inocência opera, de fato, exatamente no sentido de exigir do Estado um processo o mais célere possível, visto que a própria existência da persecução penal em face do indivíduo já pe uma situação desfavorável a seu status dignitatis”36.

Assim como a própria pena deve ser prévia e legalmente prevista em seu tempo máximo, isto é, em sua duração, também o processo, que traz as mesmas características da pena, deve ser delimitado temporalmente.

\footnotetext{
33 “O Estado indenizará o condenado por erro judiciário, assim como o que ficar preso além do tempo fixado na sentença".

34 José I. Cafferata Nores, Proceso penal y derechos humanos: la influencia de la normativa supranacional sobre derechos de nível constitucional en el proceso argentino, Buenos Aires, Editores del Puerto, 2000, p. 193.

${ }^{35}$ Op. cit., p. 502.

${ }^{36}$ Maurício Zanoide de Moraes, op. cit., p. 385.
} 


\subsection{Dificuldades processuais}

Dificuldades de ordem processual também justificam a necessidade de uma limitação do prazo máximo de duração do processo. A dificuldade para a colheita da prova aumenta com o passar do tempo, especialmente quanto à prova testemunhal, visto que o tempo esmaece as lembranças, prejudicando a reconstituição dos fatos na memória, e, assim, prejudicando e enfraquecendo o exercício da ampla defesa ${ }^{37}$.

O decurso do tempo sem dúvida influi sobremaneira sobre a forma como as lembranças percebidas no momento do delito ficam armazenadas na memória.

Num primeiro aspecto, a confirmar os ditos populares de que "o tempo é o melhor remédio", ou "o tempo tudo apaga", tem-se que a memória humana, especialmente a visual $^{38}$, que registra constantemente uma infinidade de imagens, sofre a ação do tempo de maneira bastante contundente, que provoca o seu esquecimento ${ }^{39}$ lento e gradual ${ }^{40}$.

Para TESORO, "a imagem que é fixada em nossa consciência por meio da percepção, fica conservada por um certo período de tempo; naturalmente, entretanto, ela não se mantém intacta para depois desaparecer de improviso, mas se descolore pouco a pouco, tornando-se cada vez menos precisa e detalhada, até que perde a conexão com outras lembranças e se perde definitivamente no inconsciente" ${ }^{41}$.

\footnotetext{
${ }^{37}$ Conferir, nesse sentido, a lição de Rogério Laura Tucci, segundo o qual as graves conseqüências processuais são um dos fatores que justificam a agilização do respectivo procedimento, "dada a evidente possibilidade de apagar-se, ou enfraquecer-se, com o tempo, a lembrança do fato ou dos fatos, pelas testemunhas; ou do desaparecimento de expressivos elementos de prova - fragilizando-se, então, a defesa do imputado" (Direitos e garantias individuais no processo penal brasileiro, $2^{\mathrm{a}}$ ed., São Paulo, Revista dos Tribunais, 2004, p. 254, nota de rodapé $n^{\circ} 13$ ).
}

${ }^{38}$ A. Almeida Júnior e J. B. de O. e Costa Júnior, Lições de Medicina Legal, 22 $2^{\mathrm{a}}$ ed., Companhia Editora Nacional, São Paulo, 1998, p. 547, informam que vários tipos de memória, que variam em cada pessoa: a memória auditiva, a visual e a motora.

${ }^{39}$ A. Almeida Júnior e J. B. de O. e Costa Júnior, op. cit., p. 546, ensinam que "uma vez fixadas, as imagens se conservam em estado latente. O tempo que dura essa conservação é assunto, hoje, de controvérsia. Segundo a opinião clássica, nem todas as imagens permaneceriam indefinidamente gravadas. As modernas escolas de psicologia dinâmica, a contrário, afirmam que a memória nunca perde aquilo que fixa. Para os clássicos, o fenômeno do esquecimento provém da falta de conservação; para os modernos, resulta da dificuldade de evocação".

${ }^{40}$ De acordo com Geoffrey M. Stephenson, The Psychology of Criminal Justice, Editora Blackwell, Oxford, s.d., p. 170, testes realizados no âmbito da Psicologia Forense demonstraram que a ação do tempo é minimizada quando a testemunha é previamente avisada de que será posteriormente testada. A razão para isto é que o nível de atenção no momento da percepção é muito maior nesta hipótese.

${ }^{41}$ Giorgio Tesoro, La psicologia della testimonianza, Fratelli Bocca, Torino, 1929, p. 44, em tradução livre. 
A prova testemunhal, sem dúvida, é prova de extrema relevância e, não raro, é a única utilizada para instruir o processo e embasar o convencimento do julgador.

Considerando que a maior parte das pessoas têm memória do tipo visual, a compreensão de que a memorização de imagens é bastante prejudicada com o decurso do tempo influencia bastante a idéia a respeito da relevância da celeridade na condução do processo.

Ademais, não se pode deslembrar a existência de meios de prova fundados exclusivamente na memória visual, como é o caso do reconhecimento de pessoas e coisas, que com o passar do tempo se torna absolutamente prejudicado ${ }^{42}$.

Há ainda a dificuldade para a realização de perícias, especialmente aquelas que podem ser prejudicadas com o tempo. Todas estão entre as chamadas provas do tipo irrepetível, em que o tempo pode significar a perda completa da sua fidedignidade, em prejuízo à busca da verdade dos fatos ${ }^{43}$.

Tais considerações, por certo, têm o condão de justificar a garantia da razoável duração do processo do ponto de vista processual, em razão do interesse probatório $^{44}$.

Quando o acusado não é encontrado, sendo citado por edital, e não comparecer a juízo nem constituir advogado, existe previsão do Código de Processo Penal de que o processo fica suspenso, assim com o prazo prescricional, podendo-se antecipar as provas consideradas urgentes ${ }^{45}$.

A antiga redação do artigo 366 do Código de Processo Penal permitia que o processo prosseguisse à revelia do acusado. Foi com a Lei 9.271/96 que a redação atual foi estabelecida, como medida necessária para garantir ao acusado o direito à ampla defesa e ao contraditório, já que o indivíduo citado por edital em raríssimos casos tinha

\footnotetext{
${ }^{42}$ A respeito do tema do reconhecimento de pessoas, conferir o trabalho de conclusão de concurso: Thaís Aroca Datcho Pereira, A valoração do reconhecimento de pessoas no processo penal brasileiro, defendida em dezembro de 2004, perante a Faculdade de Direito da USP, sob a orientação da $\operatorname{Prof}^{a}$. Dr $^{\mathrm{a}}$. Maria Thereza Rocha de Assis Moura.

43 "A marca da definitividade coloca-se naqueles atos insuscetíveis de serem repetidos, por motivos tais como a ação do tempo ou a transitoriedade da própria situação ou mesmo a inconveniência. Portanto, esses atos são irreproduzíveis pela própria natureza ou definitivos pelas circunstâncias" (Cf. Marta Saad, O direito de defesa no inquérito policial, Revista dos Tribunais, 2001, p. 176).

${ }^{44}$ Cf., nesse sentido, Aury Lopes Jr. e Gustavo Henrique Righi Ivahy Badaró, op. cit., p. 14.

45 “Art. 366. Se o acusado, citado por edital, não comparecer, nem constituir advogado, ficarão suspensos o processo e o curso do prazo prescricional, podendo o juiz determinar a produção antecipada das provas consideradas urgentes e, se for o caso, decretar prisão preventiva, nos termos do disposto no art. 312.”
} 
conhecimento da acusação, e acabava sendo condenado sem que tivesse a oportunidade de reagir à imputação.

Tratou-se, portanto, de medida de cunho garantista, com a suspensão do processo, pois destinada a garantir o princípio nemo inauditus damnari potest (ninguém pode ser julgado sem ser ouvido), além de preservar o direito do acusado a estar presente durante a produção da prova ${ }^{46}$.

Nesse sentido, a garantia da razoável duração do processo não foi afetada, uma vez que, em nome da necessidade de maior proteção dos direitos fundamentais do acusado, o processo fica suspenso, de modo que não há como se falar em demora para a prestação jurisdicional ou em direito a ser julgado com celeridade, pois fere completamente os direitos do indivíduo o ser acusado com celeridade nestas condições. Em nenhuma hipótese, uma garantia pode ser usada para prejudicar os direitos do indivíduo.

O grande problema da norma está em que houve a previsão de que o prazo prescricional também fica suspenso, cirando aí uma inadmissível causa de imprescritibilidade. O direito de punir do Estado não teria, assim, qualquer limite nesta hipótese, contrariando os ideais de justiça e os próprios fundamentos que justificam a existência da prescrição. Por isso é que os tribunais passaram a entender que como prazo máximo de duração do período de suspensão da prescrição será o prazo prescricional, contado segundo a pena máxima cominada, voltando a correr, após este prazo, novamente a prescrição ${ }^{47}$.

O projeto de lei $n^{0} 4.207 / 2001$ trazia a previsão de limite de duração da suspensão da prescrição, consagrando o entendimento jurisprudencial acima citado, propondo alteração do artigo 366 , que passaria a constar no $363, \S 2^{\circ}$, com a seguinte redação: “乌 $2^{\underline{o}}$ Não comparecendo o acusado citado por edital, nem constituindo defensor: I - ficará suspenso o curso do prazo prescricional pelo correspondente ao da

\footnotetext{
46 “Com relação à auto-defesa, cumpre salientar que se compõe ela de dois aspectos, a serem escrupulosamente observados: o direito de audiência e o direito de presença. O primeiro traduz-se na possibilidade de o acusado influir sobre a formação do convencimento do juiz mediante o interrogatório. $\mathrm{O}$ segundo manifesta-se pela oportunidade de tomar ele posição, a todo momento, perante as alegações e as provas produzidas, pela imediação com o juiz, as razões e as provas” (Ada Pellegrini Grinover, Antonio Scarance Fernandes, As nulidades no processo penal, $9^{a}$ ed., São Paulo, Revista dos Tribunais, 2006, p. 88).

${ }^{47}$ Tal construção fez com que, na prática, o prazo prescricional fosse duplicado, de acordo com observação feita por Gustavo Henrique Righi Ivahy Badaró, Direito Processual Penal: tomo I, Rio de Janeiro, Elsevier, 2008, p. 175.
} 
prescrição em abstrato do crime objeto da ação (art. 109 do Código Penal); após, recomeçará a fluir aquele".

Ocorre que a previsão de que o curso do processo também ficaria suspenso, por uma falha no processo legislativo, não constou da redação final submetida à sanção presidencial, o que resultou no veto de todo o dispositivo, optando-se pela manutenção do artigo 366 com sua antiga redação, sob os seguintes fundamentos: "A despeito de todo o caráter benéfico das inovações promovidas pelo Projeto de Lei, se revela imperiosa a indicação do veto do $\S 2^{\circ}$ do art. 363 , eis que em seu inciso I há a previsão de suspensão do prazo prescricional quando o acusado citado não comparecer, nem constituir defensor. Entretanto, não há, concomitantemente, a previsão de suspensão do curso do processo, que existe na atual redação do art. 366 do Código de Processo Penal. Permitir a situação na qual ocorra a suspensão do prazo prescricional, mas não a suspensão do andamento do processo, levaria à tramitação do processo à revelia do acusado, contrariando os ensinamentos da melhor doutrina e jurisprudência processual penal brasileira e atacando frontalmente os princípios constitucionais da proporcionalidade, da ampla defesa e do contraditório" 48 .

Justamente porque a previsão de suspensão do processo é uma regra criada para garantir dos direitos e garantias fundamentais do acusado no curso do processo é que a previsão antecipada de provas não prevalece como regra, ainda que se corra o risco concreto de perda gradual da força probatório, mormente a testemunhal, com o passar do tempo.

A antecipação das provas deve ser determinada em hipóteses excepcionais, apenas quanto às provas do tipo irrepetíveis e, no caso da prova testemunhal, nos casos previsto no artigo 225 do Código de Processo Penal, que assim dispõe: "Se qualquer testemunha houver de ausentar-se, ou, por enfermidade ou por velhice, inspirar receio de que ao tempo da instrução criminal já não exista, o juiz poderá, de ofício, ou a requerimento de qualquer das partes, tomar-lhe antecipadamente o depoimento".

O Supremo Tribunal Federal rechaça a possibilidade de produção da prova testemunhal na ausência do acusado como regra sob o argumento do esquecimento das lembranças dos fatos. Nesse sentido, destaca-se o seguinte julgado: “O artigo 366 do Código de Processo Penal prevê a possibilidade da produção antecipada de provas e o

48 Mensagem de veto presidencial $n^{\circ} 421$, de 20 de junho de 2008, disponível no endereço eletrônico da Presidência da República: http://www.planalto.gov.br/ccivil_03/_Ato2007-2010/2008/Msg/VEP-421-08.htm 
artigo 225, ao dispor especificamente sobre a prova testemunhal, fornece os parâmetros que autorizam a antecipação da oitiva de testemunhas. $O$ juiz não está vinculado a fórmulas genéricas, válidas para todo e qualquer caso, como o esquecimento pelo decurso do tempo e a possibilidade de mudança de domicílio, ora invocados pelo Ministério Público estadual"49.

\subsection{Necessidade de proximidade da pena em relação ao delito}

O processo há de, igualmente, durar tempo certo para que não se inviabilize, pelo prolongamento irrazoável do instrumento, o resultado visado, em última instância, pelo direito material.

Isto porque dois são os escopos buscados pelo processo penal, segundo magistério de TUCCI, ambos distintos, porém convergentes, no sentido de realizar o direito material: o de efetivação do ius puniendi, que não pode se fazer senão por meio do processo (nulla coactio sine judicio), e o de afirmação do ius libertatis, que restringe a coação estatal quando não se esteja diante de fato penalmente relevante e de autoria de crime ou de contravenção ${ }^{50}$.

Não se busca com o processo a aplicação da pena a qualquer custo. $\mathrm{O}$ processo eficiente é aquele que, “em tempo razoável, permite atingir um resultado justo, seja possibilitando aos órgãos da persecução penal agir para fazer atuar o direito punitivo, seja assegurando ao acusado as garantias do processo legal" ${ }^{\prime 5}$.

Assim, o processo há de durar tempo adequado seja para a proteção dos direitos do acusado, especialmente da ampla defesa e do contraditório, seja para não inviabilizar a realização do direito punitivo do Estado.

Do ponto de vista da teoria dos fins da pena, portanto, também se justifica a limitação temporal do processo. Qualquer que seja a teoria da pena adotada, a demora na imposição da sanção pode frustrar a realização de seus fins.

\footnotetext{
${ }^{49}$ STF, RHC 85311, Primeira Turma, Rel. Min. Eros Grau, j. 01/03/2005, DJ de 01/04/2005.

${ }^{50}$ Rogério Lauria Tucci, Teoria do Direito Processual ..., cit., p. 169.

${ }^{51}$ Antonio Scarance Fernandes, "Reflexões sobre as noções de eficiência e de garantismo no processo penal", in: Antonio Scarance Fernandes, José Raul Gavião de Almeida e Maurício Zanoide de Moraes (coords.), Sigilo no processo penal: eficiência e garantismo, São Paulo, Revista dos Tribunais, 2008, p. 16.
} 
Para a teoria absoluta (ou retributiva), a pena é vista como um mal atribuído a um outro mal (o delito), sem qualquer finalidade a ser alcançada com a sanção a não ser, por força de um imperativo categórico, a restauração da ordem jurídica atingida pelo delito ou restabelecimento do Direito lesado ${ }^{52}$. A pena, assim, seria uma forma de retribuição, de punir quem pecou (punitur quia peccatum est). Sob a perspectiva da teoria absoluta, o ser humano é tido como detentor de total livre-abrítrio, sendo responsável moralmente pelas escolhas que fizesse pelo mal ${ }^{53}$. Os limites à punibilidade eram apenas a proporcionalidade entre a pena e a gravidade da conduta e a culpabilidade ${ }^{54}$.

As teorias relativas (ou preventivas) desenvolveram-se após grave crítica dirigida à teoria absoluta com relação aos pressupostos da punibilidade, já que a tese do livre-arbítrio pressupõe que o homem conheça exatamente seu comportamento social, o que justificaria que sofresse as conseqüências da punição ${ }^{55}$.

Abandonou-se a preocupação com o passado e passou-se a refletir sobre o futuro do condenado. Era preciso que a pena também pudesse ter uma utilidade social, prevenindo novos crimes, e evitando que estes ocorressem além do naturalmente suportável pela sociedade. Assim, a prevenção pauta-se na idéia do punitur ne pecetur (punir para não pecar) ${ }^{56}$.

A teoria da prevenção geral entende que a pena deve exercer uma influência sobre a sociedade para que esta não pratique mais crimes $^{57}$, e pode ser dividida, por sua vez, em prevenção geral negativa e prevenção geral positiva.

$\mathrm{Na}$ teoria da prevenção geral negativa, a pena aplicada sobre aquele que cometeu o crime tem um efeito exemplar intimidativo sobre o restante da sociedade, que se convence da seriedade da ameaça da pena abstratamente cominada e evita cometer crimes, temerosa do castigo. "De acordo com a teoria da prevenção geral, em seu sentido negativo,

\footnotetext{
${ }^{52}$ Ver, a respeito, Sérgio Salomão Shecaira, Teoria da pena: finalidades, direito positivo, jurisprudência e outros estudos de ciência criminal, São Paulo, Revista dos Tribunais, 2002, p. 130.

${ }^{53}$ Cf. Antonio Luís Chaves Camargo, Sistema de penas, dogmática jurídico-penal e política criminal, São Paulo, Cultural Paulista, 2002, pp.38-45.

${ }^{54}$ Idem, ibidem.

${ }^{55}$ Idem, p. 44.

${ }^{56}$ Idem, pp 45-46.

${ }^{57}$ Sérgio Salomão Shecaira, op. cit., p. 131.
} 
a pena deve produzir efeitos de intimidação sobre a generalidade das pessoas, atemorizando os possíveis infratores a fim de que estes não cometam quaisquer delitos"

Já a teoria da prevenção geral positiva, que surge sob a influência das teorias sociológicas do sistema, procura atribuir legitimidade à pena, convencendo os indivíduos da correção das normas vigentes no ordenamento jurídico ${ }^{59}$, seja para a necessidade de assegurar a vigência dos valores da consciência jurídica ético-social ${ }^{60}$, ou para reafirmar a vigência da norma ${ }^{61}$, ou, ainda, para a revalidação dos valores vigentes num determinado momento histórico, para um grupo social ${ }^{62}$. "A norma deve ser, pois, estimulada em seu cumprimento, sendo esse um processo de formação do povo, com oportunidades de assimilar os valores básicos da sociedade"63.

Com relação à prevenção especial, procura-se modificar a vontade do indivíduo, no sentido de desestimulá-lo à prática de novos crimes, seja reinserindo-o na sociedade (prevenção especial positiva), seja retirando-o do meio social, neutralizando-o no cárcere (prevenção especial negativa) ${ }^{64}$.

De se ver, portanto, que em qualquer que seja a teoria a respeito dos fins da pena, seja retributiva, seja preventiva (geral ou especial, positiva ou negativa), a proximidade temporal da sanção em relação ao crime é considerada primordial.

\footnotetext{
${ }^{58}$ Idem, ibidem.

${ }^{59}$ Antonio Luís Chaves Camargo, op. cit., p. 52.

60 “La mera protección de bienes jurídicos tiene solo un fin preventivo, de carácter policial y negativo. Por el contrario, la misión más profunda del Derecho Penal es de la naturaleza ético-social y de carácter positivo. Al proscribir y castigar la inobservancia efectiva de los valores fundamentales de la conciencia jurídica, revela, en la forma más conluyente a disposición del Estado, la vigencia inquebrantable de estos valores positivos de acto, junto con dar forma al juicio ético-social de los ciudadanos y fortalecer su conciencia de permanente fidelidad jurídica”. Hans Welzel, Derecho Penal Aleman, $4^{\text {a }}$ ed., Santiago do Chile, Jurídica de Chile, 1997, p. 3.

${ }^{61}$ De acordo com o pensamento de Günther Jakobs, "Imputación jurídicopenal: desarrollo del sistema a partir de las condiciones de vigência de la norma”. In: Problemas Capitales del Derecho Penal Moderno. Trad. Javier Sánchez - Vera Gomes - Trelles. Buenos Aires, Hamurabi, 1998, p. 34.

${ }^{62}$ De acordo com o pensamento de Antonio Luís Chaves Camargo, op. cit., pp. 57-59.

${ }^{63}$ Sérgio Salomão Shecaira, op. cit., p. 132.

${ }^{64}$ Idem, p. 133.
} 
Dentro da concepção de pena como retribuição, por exemplo, o processo criminal deveria ser "bem curto para não retardar demais o castigo que deve seguir de perto o crime, se se quiser que o mesmo seja um freio útil contra os culpados"65.

Do mesmo modo, do ponto de vista preventivo, geral ou especial, a pena apenas satisfaz a sua finalidade se for aplicada rapidamente após o cometimento do delito. $\mathrm{Na}$ concepção de prevenção geral negativa, a pena deve ser aplicada rapidamente após o cometimento do delito, caso contrário, poder-se-á alcançar até mesmo o efeito inverso pretendido, de estímulo ao cometimento de novos crimes, sinalizando-se para a sociedade que a pessoa que comete um crime não é punida, dado que a pena apenas sobrevém quando já arrefecida a lembrança social acerca do crime. De igual forma, no que se refere à prevenção geral positiva, a pena deve ser aplicada de forma rápida, pois a proteção do ordenamento jurídico somente pode ser alcançada se o grupo social perceber claramente a aplicação da sanção, a se contrapor à violação da norma, o que somente é alcançado com a rápida imposição da pena.

Outra não é a conclusão para as concepções preventivas especiais, seja a negativa, seja a positiva. Nenhum efeito é alcançado sobre o indivíduo quando a imposição da pena vem fora do tempo, quando aquele indivíduo já não apresenta os mesmos valores e a mesma concepção de vida do momento do crime. Isto acontece porque a vida apresenta uma dinâmica, em que cada indivíduo vai mudando os rumos de sua história, não sendo raro que, quando da imposição da pena, venha o Estado a punir uma pessoa completamente diversa daquela que se via quando do cometimento do delito. "Trata-se de um paradoxo temporal ínsito ao ritual judiciário: um juiz julgado no presente (hoje), um homem e seu fato ocorrido num passado distante (anteontem), com base na prova colhida num passado próximo (ontem) e projetando os efeitos (pena) para o futuro (amanhã). Assim como o fato não é o mesmo que está em julgamento e, com certeza, não será o mesmo que cumprirá essa pena e, seu presente no futuro, será um constante reviver o passado"66.

Considerando, portanto, que muito da eficácia que se pretende atribuir à pena depende da sua proximidade temporal em relação ao delito, é fatal concluir que a demora no término do processo pode prejudicar a realização dos fins das penas, quaisquer

\footnotetext{
${ }^{65}$ Cesare Bonasena Marchesi di Beccaria, Dos delitos e das penas, Trad. Flório de Angelis, Edipro, Bauru, 2000 , p. 41.

${ }^{66}$ Aury Lopes Jr. e Gustavo Henrique Righi Ivahy Badaró, op. cit., p. 14.
} 
que sejam estes, caso resulte em condenação, justificando, por assim dizer, a existência de algum tipo de limitação temporal do processo.

É de se ressaltar que é fim último da prescrição tutelar e garantir a eficácia dos fins da pena, por tratar-se de instituto de direito material, e não da garantia da razoável duração do processo.

A pena que não mais atende a sua finalidade em razão do tempo é desnecessária e, portanto, ilegítima ${ }^{67}$. A prescrição penal surge, nesse contexto como um instrumento de garantia, limitando a utilização do sistema repressor, ou seja, impedindo que o indivíduo sofra uma pena, ou uma persecução penal, quando estas se mostrem desnecessárias, o que reafirma a natureza material do instituto ${ }^{68}$.

Se a prescrição soluciona o problema da ausência de legitimidade em se aplicar uma sanção penal, ou mesmo, de se processar criminalmente alguém, sem que haja necessidade em razão do tempo, ela não soluciona o problema da ilegitimidade em se restringir a liberdade de locomoção do indivíduo por tempo demasiado em razão da persecução penal, que por si só é uma sanção e estigmatiza o ser humano.

A prova de que também o processo deve ser limitado temporalmente, sob pena de frustrar esses fins da pena está em que a prescrição corre durante o curso do processo baseada na pena em abstrato, e que, após concretizada a pena na sentença, retroage o prazo prescricional, alcançando os lapsos temporais ocorridos no curso do procedimento. Todavia, a prescrição não se presta a cumprir esse papel como prioridade, pois, sendo instituto de direito material, apresenta-se apenas, no dizer de CHOUKR, como um controle atípico da longa duração do prazo da investigação e da persecutio criminis in judicio, apresentando uma série de inconvenientes ${ }^{69}$.

A limitação do estigma que recai sobre o indivíduo no curso do processo criminal somente pode ser alcançado por meio de um garantia constitucional que limite temporalmente duração da persecução penal.

\footnotetext{
${ }^{67}$ Cf. Fábio Guedes de Paula, Prescrição penal: prescrição funcionalista, São Paulo, Revista dos Tribunais, 2000, p. 190.

${ }^{68}$ Idem, p. 192.

${ }^{69}$ Fauzi Hassan Choukr, Garantias constitucionais na investigação criminal, $2^{\mathrm{a}}$ ed., Rio de Janeiro, Lumen Juris, 2001, p. 161. Conferir mais a respeito no item 1.5. infra.
} 
A idéia de que a garantia da razoável duração do processo - que, de resto, é garantia de todos os sujeitos do processo ${ }^{70}$ e da própria sociedade - tutela um direito subjetivo constitucional do indivíduo de ser julgado dentro de um prazo razoável ${ }^{71}$, impede que esta seja vista como um instrumento a ser utilizado pelo Estado a fim de dar à sociedade a impressão de que combate eficazmente a criminalidade (prevenção geral), acelerando os prazos em desrespeito à outros direitos fundamentais como os do due process of law, da ampla defesa e da presunção de inocência.

Assim, passar-se-á a discorrer sobre as diferenças essenciais entre a prescrição e a garantia da razoável duração do processo, de molde a demonstrar-se que a prescrição, por mais que signifique um controle atípico de duração do processo, não se presta à função de garantia que se espera alcançar com a garantia da razoável duração do processo.

\subsection{Prescrição e duração do processo: impossibilidade da prescrição operar como garantia constitucional de duração razoável do processo}

No sistema jurídico brasileiro, dois são os institutos que promovem um controle de limitação temporal do processo: a garantia da razoável duração do processo e a prescrição.

A origem do instituto da prescrição remonta a limitações temporais de ordem processual, especialmente na fixação de prazo para a conclusão do processo pelos romanos, com o intuito de evitar "acusações prolixas e ineficazes" 72 , o que demonstra que muitos dos fundamentos da prescrição se voltam também para a necessidade de restrição temporal do processo.

\footnotetext{
${ }^{70}$ Em diversas decisões da Corte Interamericana de Direito Humanos há, aliás, a expressa referência de que a garantia da razoável duração do processo também alcança a vítima, que possui o direito a um prazo razoável julgamento do processo. Nesse sentido, ver, dentre tantos, o Caso López Álvares versus Honduras e o caso Valle Jaramillo e outros versus Colômbia.

${ }^{71}$ Nesse sentido, defendendo a existência de um direito subjetivo constitucional do acusado (e do condenado, no processo de execução penal) a ser exercitado perante os órgãos do Poder Judiciário, instando-os a atuar num prazo razoável, ver Rogério Lauria Tucci, Direito e garantias..., cit., p. 255.

${ }^{72}$ Cf. Eduardo Reale Ferrari, Prescrição da ação penal: suas causas suspensivas e interruptivas, São Paulo, Saraiva, 1998, p. 25.
} 
Para justificar o instituto da prescrição, desenvolveram-se ao longo da história diversas teorias, sendo as principais a teoria do esquecimento, a teoria da expiação moral do criminoso, a teoria da emenda, a teoria psicológica, a teoria da dispersão das provas, teoria da presunção da negligência estatal, e a teoria político-criminal ${ }^{73}$ que, resumidamente, passaremos a analisar.

A teoria do esquecimento aposta no decurso do tempo como um poderoso fator terapêutico para a sociedade. Para esta teoria, vale o adágio popular de que, para qualquer mal, o melhor remédio é sempre o tempo. ${ }^{74}$ Assim, desde a prática do delito no caso da prescrição da pretensão punitiva - ou desde o trânsito em julgado da sentença condenatória - no caso da pretensão executória - , se se passa um longo período de tempo, variável de acordo com a gravidade do delito, sem que o Estado exerça seu direito de punir, a sociedade acaba por esquecer o impacto causado pela perturbação da ordem jurídica, tornando a imposição da sanção carente de sentido. O interesse do Estado na punição é, por assim dizer, diluído com o passar do tempo.

A teoria da expiação moral baseia-se numa presunção de que o criminoso sofre suficientes angústias com o decurso de um longo tempo sem a punição, seja furtandose à persecução estatal (no caso da prescrição da pretensão punitiva), seja fugindo (no caso da pretensão executória), com a necessidade de manter-se sempre em sobreaviso, temeroso de ser descoberto, operando as mais astutas manobras para manter-se anônimo e evadir-se de perigosas situações, seja, ainda, suportando o caráter aflitivo e estigmatizante do próprio processo (no caso da prescrição intercorrente).

$\mathrm{Na}$ redação de MACHADO, "esta teoria, fundada no sofrimento moral, firma-se na convicção de que os remorsos, os sofrimentos sofridos pelo culpável ao longo do processo, são castigos suficientes. Impor uma pena a mais seria atentar contra o princípio non bis in idem. Surge, portanto, a idéia da compensação da pena pelo sofrimento, em face da aflição e da opressão havidas no transcurso do processo" ${ }^{, 75}$.

\footnotetext{
${ }^{73}$ Cf. Eduardo Reale Ferrari, Prescrição da ação penal..., cit., p. 25.

${ }^{74}$ Para Basileu Garcia, Instituições de Direito Penal, vol. I, tomo II, São Paulo, Max Limonad, 1952, p. 702, “a prescrição é eqüitativa. Tudo passa, um dia. Há de passar, também, e ser esquecida, a ameaça do Estado de apanhar o delinqüente. Nem o ódio dos homens costuma ser invariavelmente implacável e irredutível”.

${ }^{75}$ Fábio Guedes de Paula Machado, op. cit., p. 91.
} 
Em sentido mais amplo, com foco além do processo, considera PORTO que a teoria da expiação moral presume que o culpado, com o passar do tempo "expiou suficientemente a culpa com angústias que sofreu e com remorsos que o assaltaram,"76.

É diversa da chamada teoria da emenda, porque não está condicionada a um arrependimento ou mudança de atitude ou de comportamento, dele independendo para se configurar. Basta o decurso do tempo.

A teoria da emenda, da mesma forma que a teoria da expiação moral, baseia-se numa presunção. Presume-se a emenda do agente se este, decorrido um lapso temporal determinado, não voltou a delinqüir. Neste caso, considera-se que se o criminoso passou tanto tempo sem cometer mais nenhum crime, é porque se "emendou", reintegrando-se perfeitamente à sociedade ${ }^{77}$.

Segundo a teoria psicológica, o indivíduo ao longo do tempo, tem modificada completamente a sua constituição psíquica. "Sustenta a mesma a idéia da alteração da constituição psíquica do culpado em razão do decurso do tempo. Assim, o infrator será outro indivíduo, diverso daquele anteriormente reconhecido como culpado, de forma que não se justificaria a imposição da pena devido à perda de valor e finalidade"78. $\mathrm{O}$ indivíduo, portanto, amadurece psiquicamente e se desliga do fato criminoso. A pena aplicada, nestas condições, violaria o princípio do artigo $5^{\circ}$, inciso XLV, da Constituição da República, de que a pena não passará da pessoa do delinqüente.

A teoria da dispersão das provas funda-se no fato natural de que as provas vão-se dispersando ao longo do tempo, prejudicando a busca da verdade real no processo. Assim, tanto a prova da culpa quanto a prova da inocência ficam prejudicadas ${ }^{79}$, aumentando consideravelmente as chances de ocorrerem erros judiciários, que tão graves conseqüências acarretam para a personalidade humana do atingido, bem como para a credibilidade do Poder Judiciário.

\footnotetext{
${ }^{76}$ Antonio Rodrigues Porto, Da prescrição penal, 2a ed., São Paulo, Bushatsky, 1977, p. 23.

${ }^{77}$ Cf. Eduardo Reale Ferrari, Prescrição Penal..., cit., p. 31: “A ausência de outras condutas delituosas, durante o processo, para essa teoria, seria a demonstração de que o indivíduo se regenerou, ou está ressocializado à comunidade, a não fazer mais sentido a injunção da sanção".

${ }^{78}$ Cf. Fábio Guedes de Paula Machado, op. cit., p. 93.

${ }^{79}$ Cf. Aloysio de Carvalho Filho, Comentários ao Código Penal, vol. IV, Rio de Janeiro, Forense, p. 219.
} 
Busca-se, portanto, proteger, ao mesmo tempo, o indivíduo, que fatalmente encontra dificuldades para defender-se depois de passado tanto tempo, bem como a sociedade, que demanda constantemente a segurança e a justiça na aplicação da lei penal. A persecução penal dos fatos se torna cada vez mais difícil, senão impossível, com o decurso do tempo ${ }^{80}$.

A teoria da presunção da negligência considera que se a punição não foi aplicada em um determinado tempo é porque o Estado, por meio de seus agentes, agiu de maneira negligente, subtraindo-se à eficaz persecução criminal. O indivíduo não pode ficar eternamente ameaçado, numa situação de incerteza jurídica, enquanto o Estado permanece inerte $^{81}$.

Se o Estado não soube bem movimentar a máquina repressiva, perde o direito de punir. Assim, para a teoria da presunção da negligência, a prescrição seria a perda do poder-dever de punir pelo não exercício da pretensão punitiva ou da pretensão executória durante certo tempo.

Por fim, a teoria da política criminal é mais recente e acompanha a própria evolução da Política Criminal enquanto ciência. Tem-se apontado tradicionalmente que o objetivo da política criminal é criar estratégias para prevenir e reprimir o crime ${ }^{82}$. Entretanto, a política criminal desenvolveu-se ao ponto de sobressair-se como ciência autônoma, competente para definir os limites da punibilidade ${ }^{83}$, ao mesmo tempo em que se desenvolve também a Criminologia enquanto ciência autônoma, que deixa de ser meramente experimental para tornar-se eminentemente crítica ${ }^{84}$.

A teoria da política criminal considera que a punição deve ocorrer tão somente quando for indispensável. A intervenção estatal deve limitar-se ao estritamente necessário para apaziguar a sociedade. A não punição de condutas tardias revela-se como

\footnotetext{
${ }^{80}$ Cf. Hans Welzel, op. cit., Derecho Penal Alemán: Parte General, $4^{\mathrm{a}}$ ed., Santiago de Chile, Editorial de Chile, 1997, p. 308.

${ }^{81}$ Eduardo Reale Ferrari, Prescrição Penal..., cit., p. 34.

${ }^{82}$ Cf. Jorge de Figueiredo Dias e Manuel da Costa Andrade, op. cit., p. 105, creditando a definição a Mezger.

${ }^{83}$ Idem, p. 95.

${ }^{84}$ Idem, p. 104.
} 
um instrumento possível para diminuir a própria criminalidade ${ }^{85}$. A prescrição penal, por assim dizer, é um modo político de extinção da punibilidade ${ }^{86}$.

O Estado renuncia ao seu direito de punir porque entende que a aplicação de uma punição não teria mais sentido após o decurso de um determinado lapso temporal. A prescrição seria, portanto, uma decisão política de renunciar à pretensão punitiva ou executória. O critério utilizado pelo Estado é o da necessidade da punição.

Coincidem, portanto, em grande parte, os fundamentos da prescrição retroativa e intercorrente e do direito à razoável duração do processo, ambos tendentes a limitar temporalmente a duração do processo.

A tese de aplicação retroativa da prescrição foi construída no âmbito jurisprudencial, a partir da antiga redação do artigo 110, parágrafo único, do Código Penal de 1940, que dispunha que "a prescrição, depois de transitar em julgado a sentença penal condenatória, regula-se pela pena imposta e verifica-se nos prazos fixados no artigo anterior, os quais se aumentam de um terço se o condenado é reincidente".

Duas correntes se formaram divergindo quanto à aplicação retroativa deste dispositivo. Para a primeira corrente, o prazo prescricional passaria a contar, com base na pena aplicada apenas a partir da sentença, com eficácia apenas ex nunc ${ }^{87}$. Para a segunda corrente, não havendo recurso da acusação, "não seria mais possível a aplicação uma reformatio in pejus, concretizando-se a pena e retroagindo para beneficiar o réu, como se fora pena cominada na lei" ${ }^{88}$.

Aplicadas conjuntamente, a prescrição retroativa e a prescrição intercorrente garantem um mecanismo de controle de duração da persecução penal com base na pena aplicada em concreto, pois permite que se reconheça que o processo extrapolou o limite de duração entre uma causa interruptiva e outra do procedimento,

\footnotetext{
${ }^{85}$ Cf. Eduardo Reale Ferrari, Prescrição Penal..., cit., p. 33.

${ }^{86}$ Neste sentido, Francesco Carrara, Programa del curso de derecho criminal dictado en la Real Universidad de Pisa, vol. I, Parte Geral, Buenos Aires, Depalma, 1944, p. 367.

${ }^{87}$ Defendendo esse entendimento, ver o seguinte aresto: STF, HC 29922, Rel. Hahnemann Guimarães, j. 08/09/1947.

${ }^{88}$ Nesse sentido: STF, HC 28638, julgado em 1975, STF, HC 29370, julgado em 12 de junho de 1946 e STF, HC 31651, Rel. Min, Nelson Hungria, j. 17/07/1951.
} 
ocorridas antes da prolação da sentença ${ }^{89}$, no caso de prescrição retroativa, e após a prolação da sentença, na fase recursal, no caso da prescrição intercorrente ${ }^{90}$.

No julgamento do recurso em habeas corpus $n^{\circ} 40210$, o Supremo Tribunal Federal expressamente consigna que a preocupação com a duração do processo, mormente com a previsão de tantas causas interruptivas da prescrição, influenciou na decisão pela admissão da retroatividade da prescrição: "Então aí, evidentemente, num Código que já interrompe a prescrição por vários motivos (o que faria, talvez, corar de vergonha o velho clássico Carrara) inclusive, pelo recebimento da denúncia, não seria possível admitir que a prescrição pudesse correr durante uma eternidade - com as interrupções estabelecidas no Código. Uma vez concretizada a pena máxima, deve o Juiz verificar se houve o lapso de tempo necessário para, de acordo com a própria lei, determinar a prescrição da ação penal, em face da pena concretizada" 91 .

$\mathrm{Na}$ falta de qualquer restrição legal em relação à duração do procedimento, a não ser aquela relativa ao transcurso da prescrição em abstrato do crime, a limitação veio apenas em 1985, com a reforma da Parte Geral do Código Penal, por meio de um controle atípico, trazido ao ordenamento jurídico brasileiro graças a estas construções doutrinárias e jurisprudenaciais no âmbito do Direito Penal, que deram origem ao instituto da prescrição retroativa ${ }^{92}$.

\footnotetext{
${ }^{89}$ Cf. Antonio Lopes Baltazar, Prescrição penal: prescrição da pretensão punitiva, intercorrente antecipada, da pretensão executória, da pena de multa, das penas restritivas de direito, direito comparado, Bauru, Edipro, 2003, p. 55.

90 “A partir da data da publicação da sentença, começa a correr o prazo prescricional calculado com base na pena concretizada naquela decisão. Se o prazo completar-se antes do trânsito em julgado da sentença pra defesa, ou do julgamento do recurso interposto pelo réu, consuma-se a extinção da punibilidade pela prescrição intercorrente" (Paulo José da Costa Jr., Direito Penal: curso completo, $6^{\text {a }}$ ed., São Paulo, Saraiva, 1999, p. 235). Acrescente-se que se a sentença for absolutória e o acórdão reformar a sentença em grau de apelação, condenado o acusado, o prazo passará a contar do acórdão, conforme dispõe agora expressamente o artigo 117, inciso IV do Código Penal.

${ }^{91}$ STF, RHC 40.210, Rel. Min. Evandro Lins e Silva, j. 16/10/1963, DJ 12/03/1964.

${ }^{92}$ Cf. Fauzi Hassan Choukr, Garantias Constitucionais..., cit., p. 161.
} 
Este sistema, todavia, não resolve o problema da duração do processo em si mesmo, com toda a estigmatização dele advinda, ou mesmo dos recursos e esforços nele despendidos em vão, pois depende da fixação da pena em eventual sentença condenatória, não servindo, portanto, para exercer qualquer controle de duração - a não ser aquele imposto pela prescrição com base na pena máxima cominada - quando o acusado vier a ser absolvido. Essa é, aliás, a principal crítica de CHOUKR quanto à utilização do instituto da prescrição como controle de duração do processo: "Mas os inconvenientes da forma como a situação está regulada são inúmeros. O primeiro deles é que esse sistema delimita o tempo a posteriori, já no final da ação, quando o juiz proferir sua sentença e forem efetuados os cálculos do art. 109 (eventualmente com concurso do art. 114) do Código Penal. Isto significa que o Estado movimentou toda a máquina repressiva para, no final de sua atividade, declarar que o período investigatório superou o máximo que lhe era permitido e sancionando a morosidade com a imprestabilidade de utilização de seus elementos informativos"93.

Por basear-se na pena aplicada em concreto na sentença penal, este tipo de controle é mais efetivo do que aquele baseado na pena máxima, mas ainda não se mostra proporcional, admitindo que um processo possa durar muito mais tempo do que a própria pena aplicada na sentença. Aliás, por esta mesma razão, não cumpre qualquer papel limitador relevante quando se trata de crime a

${ }^{93}$ Idem, ibidem. 
que a pena cominada for muito elevada, não apresentando praticamente nenhum efeito de limitação da duração irrazoável do processo.

A existência do instituto da prescrição não esgota, portanto, a necessidade de um prazo para o término do processo, mesmo no que diz respeito à prescrição que se dá no curso do processo.

É que no âmbito processual penal, a idéia de duração razoável do processo está ligada ao tempo ou prazo adequado, necessário e proporcional tanto para propiciar a busca da verdade, quanto para garantir o exercício da ampla defesa e de outros direitos fundamentais de natureza processual, enquanto no que se refere à prescrição, o prazo é aquele prazo máximo dentro do qual o direito de punir ainda consegue se justificar, geralmente o suficiente para não inviabilizar a realização do fim da pena a ser aplicada.

São, portanto, "prazos independentes e, em casos concretos, um processo pode alcançar seu prazo razoável sem que a prescrição tenha se produzido, todavia, esta pode operar em outro em que, todavia, ainda não se tenha chegado ao limite de sua duração razoável"94.

Em delitos apenados com penas muito elevadas a distinção entre os dois conceitos fica ainda mais evidente. Que crimes de gravidade mais acentuada tenham prazos prescricionais bastante elevados, não se discute, mas que a duração do processo em que estes crimes venham a ser apurados não pode seguir o mesmo patamar parece muito tranqüilo, já que não se pode admitir que uma pessoa fique sob o peso de um procedimento criminal por tanto tempo, sem um provimento judicial final.

Tal problemática se acentua ainda mais diante da existência de momentos interruptivos da prescrição dentro do procedimento, que elevam ainda mais o tempo possível de duração do processo, chegando, em não raras ocasiões, a um prazo superior à própria pena aplicável ao caso, o que fere frontalmente o princípio da razoabilidade. "No Brasil, os prazos previstos para a ocorrência da chamada prescrição da pretensão punitiva (pela pena aplicada ou in abstrato) são inadequados para o objeto em questão, pois excessivos (principalmente pela pena em abstrato)" 95 .

\footnotetext{
${ }^{94}$ Daniel R. Pastor, El plazo razonable en el proceso del Estado de Derecho: una investigación acerca del problema de la excesiva duración del proceso penal y sus posibles soluciones, Buenos Aires, Ad-Hoc, Honrad-Adenauer Stiftung, 2002, p. 447, traduzido livremente.

${ }^{95}$ Aury Lopes Jr., "O tempo como pena processual..., cit., p. 207, na nota de rodapé no 41.
} 
Da mesma forma, a previsão de crimes imprescritíveis, tais como o racismo, ainda que bastante questionável, termina por desvincular completamente a idéia de prescrição intercorrente da garantia da razoável duração do processo.

Outra distinção entre ambos os institutos a ser ressaltada, é que enquanto os prazos prescricionais se pautam pela gravidade de cada crime, sendo mais longos conforme se trate de crimes mais graves, o prazo para o término da persecução penal deve atender, fundamentalmente, ao critério da complexidade da causa, atendendo a um aspecto meramente processual. Está claro que um processo em que seja apurado um crime de latrocínio, em que a prescrição em abstrato é de 20 anos, pode ser mais simples e expedito que um processo no qual se apure um crime de sonegação fiscal ou de quadrilha, em que o prazo prescricional é bem mais reduzido. Tais exemplos demonstram a fragilidade do argumento em prol da suficiência da prescrição para os fins de assegurar um processo penal num prazo razoável.

A distinção, então, é primordial para se afastar o argumento de que não é necessária a fixação de um prazo máximo de duração do processo, porque a prescrição retroativa e a intercorrente cumpririam esse papel.

Muitos autores consideram que o prazo prescricional que flui durante o curso do procedimento, uma vez alcançado, conduz à extinção da punibilidade, devendo ser admitido como o prazo máximo de duração de cada processo. E, com efeito, o prazo prescricional, por atingir o próprio direito material, acaba pondo fim ao próprio processo. O prazo legal da prescrição de um delito pode, assim, servir como o prazo máximo de duração de um processo específico, já que, em termos lógicos, “com a extinção da relação material (extinção da punibilidade) desaparece toda a possibilidade de exercer a ação ou de continuar o seu exercício" 96 .

Em lição bastante elucidativa, FRAGOSO assim aborda esta função de extinção do processo pela via da prescrição, defendendo que a prescrição não apresenta apenas um caráter jurídico-material, mas que também apresenta um caráter processual ${ }^{97}$ :

\footnotetext{
${ }^{96}$ Daniel R. Pastor, El plazo razonable..., cit., p. 446.

97 Trata-se da chamada teoria mista a que admite que a prescrição possui um caráter misto, reunindo um caráter material e, ao mesmo tempo, um caráter processual. Além de Heleno Cláudio Fragoso, Lições de Direito Penal - Parte Geral, 16 a ed., atualizado por Fernando Fragoso, Rio de Janeiro, Forense, 2004, p. 514, destaca-se, mais atualmente, defendendo a natureza mista do instituto da prescrição Eduardo Reale Ferrari, Prescrição Penal... cit., p. 22.
} 
“A prescrição penal representa, por uma lado, a perda do interesse da perseguição e no castigo, porque, com o decurso do tempo, desaparecem as razões que justificam a pena. Por outro lado, a prescrição constitui impedimento processual. Em boa verdade, o aspecto processual da prescrição é o mais nítido, sobretudo quando se trata da prescrição da pretensão punitiva. Parece claro que neste último caso desaparece o direito do Estado à persecução: a prescrição constitui um pressuposto negativo, implicando a extinção do processo sem decisão do mérito. Ocorrendo a prescrição antes da sentença, não se julga a ação improcedente. O juiz declara extinta a punibilidade põe fim ao processo"98.

Todavia, a utilização da prescrição deve ser apenas supletiva, de molde a corrigir uma falha do sistema no qual não existe a regulação específica acerca do direito à razoável duração do processo. Não há problema na utilização da prescrição para fazer valer o direito à razoável duração do processo em hipóteses concretas. O problema é entender que a prescrição é suficiente para esse fim, o que não é verdade. Como bem ressaltado por PASTOR, a coincidência entre a prescrição e a garantia da razoável duração do processo é apenas aleatória, e não satisfaz efetivamente, e em todos os casos, o direito do imputado a ser julgado dentro de um prazo razoável ${ }^{99}$.

Apenas enquanto não estabelecido um prazo máximo de duração do processo, a prescrição pode servir, incidentalmente, como uma medida suficientemente delimitada de contenção do poder punitivo, levando em consideração o fator tempo de duração do processo. Isto porque, além de trazer a idéia de um prazo de duração, ainda, tem a vantagem de acarretar uma conseqüência jurídica inquestionável, de extinção da punibilidade e, em conseqüência, do processo, especialmente com relação aos crimes apenados com penas mais baixas.

Aliás, é de se ver que a prescrição intercorrente e a retroativa, com base na pena concretamente fixada na sentença, importa em uma criação artificial, justamente no sentido de impedir o prolongamento do procedimento, o que demonstra um desvirtuamento do instituto da prescrição, em razão de uma necessidade de restrição temporal do processo, que deveria ser de alçada do próprio direito processual, fixando-se legalmente um prazo máximo de duração da persecução penal.

\footnotetext{
${ }^{98}$ Heleno Cláudio Fragoso, op. cit., p. 514.

99 Idem, p. 448. Ainda para o mesmo autor, "apenas casualmente é possível que a prescrição do delito funcione como garantia do direito fundamental do imputado a ser julgado dentro de um prazo razoável" (Idem, p. 450, traduzido livremente).
} 
A ilegitimidade deste regime prescricional no curso do processo, que prevê inclusive causas de suspensão e interrupção do prazo de acordo com a superveniência de atos específicos do procedimento, é claramente exposta por PASTOR, para quem a interrupção da prescrição por atos do procedimento é uma "circunstância demonstrativa da ilegitimidade deste regime, dado que, assim como nem mesmo a subsistência da dor pode convalidar a imprescritibilidade dos crimes, tampouco os atos do procedimento podem manter eternamente vivo o exercício de um poder que se reputa constitucionalmente limitado também no tempo"100.

Por estes motivos, passar-se-á a analisar a garantia da razoável duração do processo, assim como o seu fundamento constitucional, no contexto de garantia dos direitos fundamentais. O processo há de ser rápido para preservar ao máximo o status dignitatis do acusado durante a apuração de um delito.

\section{GARANTIA DA RAZOÁVEL DURAÇÃo DA PERSECUÇÃo PENAL}

\subsection{Breve escorço histórico}

O prolongamento da duração do processo além do razoável não é um problema novo. ${ }^{101}$ Os romanos, por exemplo, já se preocupavam com a demora na prestação jurisdicional, tanto que buscaram limitar a duração dos processos criminais, sendo que, sob o império de Justiniano, o prazo máximo de duração de um processo era de dois anos e, à época de Constantino, foi reduzido para um ano ${ }^{102}$.

\footnotetext{
${ }^{100}$ Idem, p. 457, traduzido livremente.

${ }^{101}$ Cf. José Rogério Cruz e Tucci, Tempo e Processo, Revista dos Tribunais, São Paulo, 1997, p. 16: “O problema da excessiva duração do processo judicial é mesmo tão antigo quanto a própria história do direito processual: desde o nascimento do processo de conotação pública, no direito romano pós-clássico, vêm testemunhados os efeitos desfavoráveis que a demora no término das demandas acarreta para a justiça”.

102 Theodor Mommsen, Derecho Penal Romano, Bogotá, 1991, p. 308: “Carecemos de notícias suficientes a respeito de quanto duravam realmente os processos criminais. Nos tempos da República e nos primórdios do Império, parece que esta duração era desmedida. Leis municipais da época de César dispunham que o tribunal do júri nomeado para julgar uma causa deveria funcionar 20 dias no máximo desde sua constituição até a sentença definitiva. Nos tempos posteriores, parece que tanto a cognição como a acusação foram
} 
Encontram-se exemplos da mesma inquietação na Magna Charta

Libertatum, de 1.215, em que o monarca se comprometia a não denegar, nem retardar um direito ou a justiça a quem quer que fosse ${ }^{103}$, e nas Sete Partidas alfonsinas ${ }^{104}$, em que havia a determinação de que nenhum processo poderia durar mais que três anos ${ }^{105}$.

A partir do momento em que o Estado tomou para si o monopólio da administração da justiça, substituindo-se aos particulares ${ }^{106}$, surgiu, tanto para a coletividade, quanto para cada indivíduo envolvido no processo, um direito subjetivo à prestação jurisdicional, idéia esta consagrada, por exemplo, na antiga fórmula da proibição do non liquet, impondo-se ao Estado-juiz a compulsoriedade de uma decisão ${ }^{107}$. É vedado ao Estado o constante adiamento da decisão do conflito que lhe é submetido, eternizando a incerteza.

O direito à prestação jurisdicional tornou-se, portanto, obviamente indissociável do direito à prestação jurisdicional tempestiva, exercida dentro de um lapso temporal razoável. Isso porque a decisão tardia, assim como a mera ausência de decisão,

ampliadas, em decorrência do que, o corrente era que a respeito da última se exigisse que o autor que interpusesse uma ação consubstanciasse o negócio em um ou dois anos no máximo. Este prazo foi logo fixado em lei, dispondo Constantino que o prazo deveria ser de um ano, a contar-se da litiscontestação; Justiniano o elevou para dois anos, de maneira que dentro desse prazo tinha que concluir-se a causa, sob pena de tergiversação, pena que poderia ser elevada em determinadas circunstâncias" (tradução livre).

103 "To no one we will sell, to no one deny or delay right or justice", conforme a versão inglesa, hoje correspondente ao artigo 40, trazida por Daniel Pastor, "Acerca del derecho fundamental al plazo razonable de duración del proceso penal". In: Revista Brasileira de Ciências Criminais, $\mathrm{n}^{\circ}$ 52, jan./fev. 2005, São Paulo, Revista dos Tribunais, p. 209.

${ }^{104}$ Ley XII, Terceira Partida: "Cabamiento e fin, devem dar derechamente los juezes, a los pleytos que fueron començados, delante dellos, lo mas ayna que pudieren. Ca fegund dixerõ los fabios antiguos, ningund pleyto, non fe puede mucho alõgar, ante los judgadores, derechueros e acuciofos" (Las Siete Partidas, glofadas por el Licenciado Gregório Lopez, Salamanca, 1555, p. 22)

${ }^{105}$ Ley XXVIII, Terceira Partida: “(...) mas fi las partes non fen alaffen plazo, nin dia cierto, aqueles judgadores libaffen el pleyto: eftonce dezimos que lo deuen librar lo mas ayna que pudiere. De manera que non fe aluengue, defde el dia que lo recibieron, mas de a três años. Ca fi defde tiempo adelante, quifieffen vfar de fu oficio, non lo podrian fazer" (Idem, p. 28).

${ }^{106}$ Cf., nesse sentido, Rogério Lauria Tucci, Teoria do Direito Processual Penal - jurisdição, ação e processo penal (estudo sistemático), São Paulo, Revista dos Tribunais, 2002, pp. 18 e 19, ao tratar do conceito de jurisdição: “(...) Trata-se, com efeito, de um poder-dever de categorizados e especializados funcionários do Estado, que se realiza mediante atividade substitutiva à dos membros da comunhão social. $\mathrm{E}$ isso, certa e necessariamente, em virtude da assunção monopolística, por ele - Estado - , da administração da justiça, e conseqüente vedação, em regra, de atuação autodefensiva, por aqueles, de seus afirmados direitos subjetivos".

${ }^{107}$ Cf. Tércio Sampaio Ferraz Jr., Introdução ao estudo..., cit., p. 263. 
não consegue atingir o fim de pacificação social almejado pelo Estado por meio do processo $^{108}$.

Já se dizia, com muita propriedade, que "a demora na administração da justiça constitui, na verdade, pura denegação de justiça"109. BECCARIA, da mesma maneira, aconselhava com veemência, já sob a influência do Iluminismo, que o tempo de duração do processo criminal deveria ser "bem curto para não retardar demais o castigo que deve seguir de perto o crime, se se quiser que o mesmo seja um freio útil contra os culpados" $" 110$.

A primeira vez em que a garantia da razoável duração do processo penal apareceu de forma expressa como um direito fundamental, se bem que ainda com contornos exclusivamente de celeridade, foi na Declaração de Direitos da Virgínia, em 1776, assegurando a toda pessoa submetida a uma persecução penal um juízo rápido e

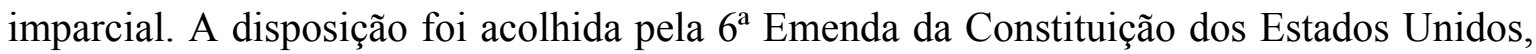
segundo a qual "em todos os juízos criminais o acusado gozará do direito a um processo rápido".

A partir da Segunda Guerra Mundial, a preocupação com a salvaguarda de direitos fundamentais se intensificou e a garantia de um prazo razoável para a duração do processo passou a constar de praticamente todas as declarações de direitos humanos.

Assim é que, em 1948, a Declaração Americana dos Direitos e Deveres do Homem, dispôs que "toda pessoa pode recorrer aos tribunais para fazer respeitar os seus direitos. Deve contar, outrossim, com processo simples e breve, mediante o qual a justiça a proteja contra atos de autoridades que violem, em seu prejuízo, qualquer dos direitos fundamentais consagrados constitucionalmente".

A regra, até então, limitava-se aos processos em geral, refletindo apenas um empenho no sentido de que os processos não deveriam se eternizar, evitando-se que pudessem ser utilizados como mecanismo pelo Estado para a negação do direito do particular.

\footnotetext{
108 “Apresenta-se o processo, com efeito, como instrumento mediante o qual toda a atividade compreendida na ação judiciária se desenvolve - um instrumento, técnico, público, político e ético de distribuição de justiça" (Rogério Lauria Tucci, Teoria do Direito Processual..., cit., p. 157.

${ }^{109}$ A frase é atribuída comumente ao antigo Conselheiro De La Bruyere, conforme noticia José Rogério Cruz e Tucci, Tempo e processo, cit., p. 15. Em sentido muito semelhante, tornou-se célebre também a máxima cunhada por Rui Barbosa de que "justiça atrasada não é justiça, senão injustiça qualificada e manifesta" (Oração aos moços/ O dever do advogado, $2^{\mathrm{a}}$ ed., Campinas, Russell, 2005, p. 47).

${ }^{110}$ Cesare Bonasena Marchesi di Beccaria, op. cit., p. 41.
} 
Em 1950, com a Convenção Européia para Salvaguarda dos Direitos do Homem e das Liberdades Fundamentais, a preocupação com a duração dos processos foi

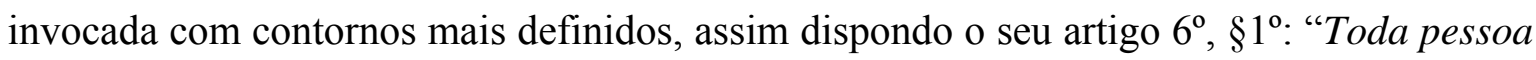
tem o direito a que sua causa seja ouvida com justiça, publicamente, dentro de um prazo razoável por um Tribunal independente e imparcial estabelecido pela lei, que decidirá sobre os litígios sobre os seus direitos e obrigações de caráter civil ou sobre o fundamento de qualquer acusação em matéria penal dirigida contra ela".

Percebe-se, portanto, que, já nesse documento internacional, houve a inclusão de regra especificamente voltada à demora do processo de natureza penal, referindo-se expressamente à razoabilidade do prazo para que o tribunal decida sobre o fundamento da acusação penal dirigida contra o indivíduo.

Tal fato demonstra, por assim dizer, que a perplexidade com os efeitos da demora do processo penal já era sentida na década de 50, especialmente no que se refere aos casos em que o acusado respondia ao processo encarcerado, sendo que a Convenção Européia também dispôs em seu artigo $5^{\circ}, \S^{\circ}$ : “Toda pessoa presa ou detida nas condições previstas no parágrafo primeiro, ' $c$ ', do presente artigo, deve ser trazida prontamente perante um juiz ou um outro magistrado autorizado pela lei a exercer a função judiciária, e tem o direito de ser julgado em um prazo razoável ou de ser posto em liberdade durante a instrução. O desencarceramento pode ser subordinado a uma garantia que assegure o comparecimento da pessoa à audiência".

Surge, então, pela primeira vez, a idéia de que a conseqüência da ultrapassagem do prazo considerado razoável para o término do processo é a colocação do acusado em liberdade. Tal proposição é posta, como se pode verificar, como uma alternativa à duração excessiva do processo no seguinte sentido: o indivíduo tem o direito a que seu processo termine em um prazo razoável ou que, ultrapassado este, seja colocado em liberdade. Não há referência, então, ao direito de julgamento rápido pelo acusado que responde ao processo solto, nem tampouco se resolve eventual demora posterior ao desencarceramento.

Em 1966, o Pacto Internacional sobre os Direitos Civis e Políticos dispôs em seu artigo $9^{\circ}, \mathrm{n}^{\circ}$ 1: “Qualquer pessoa, presa ou encarcerada em virtude de infração penal, deverá ser conduzida, sem demora, à presença do juiz ou outra autoridade habilitada por lei a exercer funções judiciais e terá o direito de ser julgada em prazo razoável ou de ser posta em liberdade. A prisão preventiva de pessoas que aguardam em liberdade não deverá constituir regra geral, mas a soltura poderá estar condicionada a 
garantias que assegurem o comparecimento da pessoa em questão à audiência, a todos os atos do processo e, se necessário for, à execução da sentença". E, mais adiante, no artigo 14, no 3, c: “Toda pessoa acusada de um delito terá direito em plena igualdade a, pelo menos às seguintes garantias: (...) a ser julgada sem dilações indevidas”.

Mais uma vez, percebe-se a tendência, para o processo penal, de se restringir o alcance da garantia, limitando a sua eficácia somente ao réu preso, e admitindose, por via indireta, a possibilidade de continuidade do processo criminal extemporâneo, desde que garantida a colocação do acusado em liberdade, admitindo-se, inclusive a exigência de garantias para assegurar o seu comparecimento aos restantes atos processuais. Permanece o prazo final de término do processo penal completamente indefinido.

Em destaque para a realidade brasileira, está a Convenção Americana de Direitos Humanos, de 1969. Dispõe o artigo $7^{\circ}, \mathrm{n}^{\mathrm{o}}$ 5: “Toda pessoa detida ou retida deve ser conduzida, sem demora, à presença de um juiz ou outra autoridade autorizada pela lei a exercer funções judiciais e tem direito a ser julgada dentro de um prazo razoável ou a ser posta em liberdade, sem prejuízo de que prossiga o processo. Sua liberdade pode ser condicionada a garantias que assegurem o seu comparecimento em juízo".

Prossegue o artigo $8^{\circ}, \mathrm{n}^{\mathrm{o}}$ 1, afirmando: "Toda pessoa tem direito a ser ouvida, com as devidas garantias e dentro de um prazo razoável por um juiz ou tribunal competente, independente e imparcial, estabelecido anteriormente por lei, na apuração de qualquer acusação penal formulada contra ela ou para que se determine seus direitos $e$ obrigações de natureza civil, trabalhista, fiscal ou de qualquer outra natureza”.

No mesmo sentido, dispõe o seu artigo 25, $\mathrm{n}^{\mathrm{o}} 1$, que: “Toda pessoa tem direito a um recurso simples e rápido ou a qualquer outro recurso efetivo...". De extrema importância o dispositivo em questão, voltado à problemática do sistema de recursos, muito criticado no Brasil por caracterizar uma estrutura muito burocrática e ineficiente.

Acolhendo a mesma tendência dos tratados internacionais, a garantia da razoável duração do processo encontrou abrigo nas constituições de muitos Estados, tais como Canadá $^{111}$, México ${ }^{112}$, Japão ${ }^{113}$, Portugal $^{114}$, Espanha ${ }^{115}$ e Itália ${ }^{116}$.

\footnotetext{
${ }^{111}$ Na Carta Canadense dos Direitos e Liberdades, de 1982, o artigo 11, 'b', que assim dispõe: “Toda pessoa demandada tem o direito de ser julgada dentro de um prazo razoável”.

112 “Art. 20. Em todo o juízo criminal terá o acusado as seguintes garantias: VIII - será julgado antes de 4 meses se se tratar de delitos cuja pena máxima não exceda dois anos de prisão; e antes de um ano se a pena máxima exceder esse tempo".

${ }^{113}$ Art. 37.1: "Em qualquer causa criminal o acusado tem o direito a um procedimento perante um tribunal imparcial".
} 
No Brasil, com a edição do Decreto Legislativo $n^{0}$ 27, de 26 de maio de 1992, o Pacto de São José da Costa Rica, como ficou conhecida a Convenção Americana de Direito Humanos, entrou em vigor do ponto de vista doméstico, recepcionado pelo direito interno.

\subsection{Desenvolvimento e reconhecimento no Brasil}

No Brasil, não houve o reconhecimento expresso da garantia da razoável duração do processo dentre os direitos fundamentais do artigo $5^{\circ}$ pelo constituinte de 1988 , mas já era corrente, na doutrina, a afirmação de que esta, embora não viesse expressa no texto constitucional, decorria naturalmente de outras garantias, principalmente a do devido processo legal $^{117}$ e a do acesso à justiça ${ }^{118}$. Para chegar a esta aproximação, a doutrina se baseava freqüentemente no exemplo norte-americano, que inclui a cláusula do speedy trial na cláusula do devido processo legal. ${ }^{119}$

\footnotetext{
${ }^{114} \mathrm{Na}$ Constituição Portuguesa de 1976, com redação dada pela Reforma de 1982, assim estabelece o artigo 32: "Todo o argüido se presume inocente até o seu trânsito em julgado a sentença de condenação, devendo ser julgado no mais curto prazo compatível com as garantias de defesa".
}

115 Dispõe o artigo 24, n⿳2 da Constituição espanhola de 1978: “Todos têm direito ao juiz ordinário determinado previamente por lei, à defesa e à assistência de advogados, a ser informada da acusação contra si deduzida, a um processo público sem dilações indevidas e com todas as garantias (...)”.

${ }^{116}$ Artigo 13, parte final: "A lei estabelecerá limites máximos para o encarceramento preventivo".

${ }^{117}$ Ver, por todos, José Rogério Cruz e Tucci, Tempo e processo, cit., pp. 87 e 88: "Em síntese, a garantia constitucional do devido processo legal deve ser uma realidade durante as múltiplas etapas do processo judicial, de sorte que ninguém seja privado de seus direitos, a não ser que no procedimento em que este se materializa se constatem todas as formalidades e exigências em lei previstas.

Desdobram-se estas nas garantias: a) de acesso à justiça; b) do juiz natural ou preconstituído; c) de tratamento paritário dos sujeitos parciais do processo; d) da plenitude de defesa, com todos os meios e recursos a ela inerentes; e) da publicidade dos atos processuais e da motivação das decisões jurisdicionais; e f) da tutela jurisdicional dentro de um lapso temporal razoável".

No mesmo sentido, Aury Lopes Jr. e Gustavo Henrique Righi Ivahy Badaró, op. cit., p. 17.

118 Cf. Flávia de Almeida Montigelli Zanferdini, "Prazo razoável - direito à prestação jurisdicional sem dilações indevidas", Cadernos Jurídicos da Escola Paulista da Magistratura, ano 4, n 13, jan./fev. 2003, São Paulo, p. 118.

${ }^{119}$ Cf., a respeito das cláusulas que integram o due processo of law na construção norte-americana, Carlos Roberto de Siqueira Castro: "Como princípio condicionante do processo criminal, a cláusula do due process of law enfeixava garantias 'explícitas' e 'implícitas' no sistema de liberdades protegido pela Constituição. Dentre as garantias adotadas expressamente no estatuto constitucional norte-americano, menciona-se a proibição de edição de bill of attainder e de leis retroativas (ex post fato law), ambas tratadas no art. $1^{\circ}$, Seção

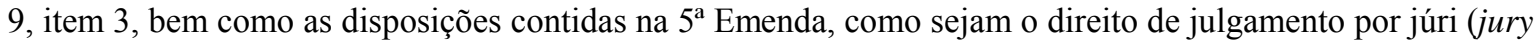
trial), a proibição de alguém ser julgado duas vezes pelo mesmo fato (double jeopardy) e a vedação de auto- 
A garantia da razoável duração do processo também era comumente relacionada à regra da celeridade processual, e bem assim, a da economia processual. De acordo com o princípio da celeridade, o processo deve ser célere, rápido e expedito, que é o que, em última instância, também se busca com a garantia da razoável duração do processo.

A diferença está em que a noção de razoável duração do processo não integra apenas a celeridade, mas constitui também um mecanismo de controle do processo precipitado.

Ademais, no processo penal não há que se falar em economia processual, no mesmo sentido conhecido pelo processo civil. Busca-se, evidentemente, que o processo seja célere e barato, como de resto devem ser todos os atos do Estado. Mas no processo penal, como a finalidade maior é a proteção de direitos fundamentais, a economia processual apenas pode ser privilegiada quando não houver qualquer prejuízo à busca da verdade e à garantia dos direitos fundamentais.

A própria determinação constitucional do $\S 2^{\circ}$ do artigo $5^{\circ}$, segundo a qual “os direitos e garantias expressos nesta Constituição não excluem outros decorrentes do regime e dos princípios por ela adotados, ou dos tratados internacionais em que a República Federativa do Brasil seja parte”, permitia afirmar com segurança que a garantia do prazo razoável para a duração do processo integrava o sistema de garantias constitucionais mesmo sem uma previsão expressa.

Finalmente, com a Emenda à Constituição n ${ }^{0} 45$, de 8 de dezembro de 2004, foi acrescentado o inciso LXXVIII ao artigo $5^{\circ}$, reconhecendo-se expressamente a garantia a todos, no âmbito judicial e administrativo, da razoável duração do processo e dos meios que garantam a celeridade de sua tramitação.

Com a superveniência da Emenda $n^{\circ} 45$ que, ao agregar-se ao cenário constitucional, dispôs de maneira clara que devem ser assegurados os meios que viabilizem a celeridade da tramitação dos processos de qualquer espécie, fica patente a necessidade de complementação legislativa, trazendo certa perplexidade à doutrina, que se vê diante de

incriminação forçada. Ajuntem-se, ainda, as garantias ditadas pela $6^{\mathrm{a}}$ Emenda, a saber, o direito a um julgamento rápido e público (speeddy and public trial), por um júri imparcial e com competência territorial predeterminada, bem como o direito a ser informado acerca da natureza e causa da acusação (fair notice), além do direito de defesa e ao contraditório, consistente na possibilidade de confrontar testemunhas de acusação, produzir provas, inclusive, de obter compulsoriamente o depoimento de testemunhas de defesa, como de resto o direito à assistência de advogados" ( $O$ devido processo legal e a razoabilidade das leis na nova Constituição do Brasil, Rio de Janeiro, Forense, 1989, pp. 34-35). 
norma de aplicação imediata, por versar sobre direito fundamental, mas que possui conteúdo vago e impreciso, além de padecer ainda de disciplina infraconstitucional ${ }^{120}$.

O termo ou nomenclatura empregados pelo texto da Emenda $\mathrm{n}^{\mathrm{o}} 45$ "razoável duração do processo" apresenta maior vantagem em relação ao termo "processo sem dilações indevidas", também muito utilizado ${ }^{121}$. Isto porque a garantia apresenta duas faces: não só o direito à não dilação excessiva (ou irrazoável) da duração de um processo, como também o direito à sua não abreviação excessiva (ou irrazoável).

Com efeito, o respeito às garantias processuais, mormente a garantia da ampla defesa, não pode ser sacrificado jamais em nome de um processo célere ${ }^{122}$. TORNAGHI já advertia, com propriedade, que é desejada a celeridade, "mas sempre cuidando que não se mutilem as garantias, quer de observância do Direito objetivo, quer de respeito aos direitos subjetivos das partes ou de terceiros. O acerto da decisão prima sobre a sua presteza. É preciso que a ligeireza não se converta em leviandade, que a pressa não acarrete a irreflexão. $\mathrm{O}$ juiz deve buscar a rápida solução do litígio, mas tem de evitar o açodamento, o afogadilho, a sofreguidão. Deve ser destro, sem ser precipitado; pontual, sem imprudência. O juiz inconsiderado é ainda pior que o vagaroso. A observância rigorosa das formas e prazos legais é melhor receita para conciliar a rapidez e a segurança" $" 123$.

Aliás, em consonância com essa idéia, encontra-se o artigo $8^{\circ}, \mathrm{n}^{\circ} 2$, c, do Pacto de São José da Costa Rica, que garante a toda pessoa, durante o processo, "a

\footnotetext{
${ }^{120}$ Cf. André Luiz Nicolitt, A duração razoável do processo, Rio de Janeiro, Lumen Juris, 2006, p. xxi.

${ }^{121}$ A expressão é utilizada pela Constituição Espanhola (art. 24: "todos tienen derecho al juez ordinario predeterminado por la ley, a la defensa y a la asistencia de letrado, a ser informados de la acusación formulada contra ellos, a un proceso público sin dilaciones indebidas y con todas las garantías, a utilizar los medios de prueba pertinentes para su defensa, a no declarar contra sí mismos, a no confesarse culpables y a la presunción de inocencia) e, em regra, é a adotada nos países da América Latina de língua espanhola.

${ }^{122}$ De acordo com J.J. Gomes Canotilho, Direito Constitucional e teoria da constituição, $5^{\mathrm{a}}$ ed., Almedina, Coimbra, 2002, p. 49: “A exigência de um processo sem dilações indevidas, ou seja, de uma proteção judicial em tempo adequado não significa necessariamente 'justiça acelerada'. A aceleração da proteção judicial que se traduza em diminuição de garantias processuais e materiais (prazo de recurso, supressão de instâncias excessivas) pode conduzir a uma justiça pronta mas materialmente injusta. Noutros casos, a existência de processos céleres, expeditos e eficazes - de especial importância no âmbito penal, mas extensiva a outros domínios (cfr. Art. 20\%/5, aditado pela LC 1/97) - é condição indispensável de uma proteção jurídica adequada (ex.: prazos em caso de habeas corpus, apreciação de prisão preventiva dentro do prazo de 48 horas, suspensão de eficácia de actos administrativos, procedimentos cautelares)".

${ }^{123}$ Hélio Bastos Tornaghi, Comentários ao Código de Processo Civil, v. 1, Revista dos Tribunais, São Paulo, 1974, p. 382.
} 
concessão ao acusado do tempo e dos meios adequados para a preparação de sua defesa" ${ }^{124}$.

A concentração de atos ou supressão de etapas processuais visando atingir maior celeridade deve ser aplicada com bastante cuidado para que, em nome de economia de recursos, não seja prejudicado o amplo exercício da defesa, deixando-se de garantir, por exemplo, o tempo necessário para a avaliação da prova produzida e a entrevista prévia ao interrogatório (e reservada) com o advogado, momento em que a estratégia de defesa pode ser traçada, já que o interrogatório exsurge como meio de defesa.

THUMS demonstra bastante preocupação com a existência de procedimentos extremamente abreviados, que possibilitam verdadeiros julgamentos sumários, a exemplo do que ocorre com os traficantes na China ${ }^{125}$, e, mais recentemente, com o julgamento de criminosos de guerra ou terroristas nos Estados Unidos ${ }^{126}$. Para o autor, a ausência de um exame criterioso da prova em face da necessidade de uma sentença imediata compromete terrivelmente os princípios democráticos do processo, revelando-se até mesmo mais prejudicial do que a demora no julgamento, em determinadas situações ${ }^{127}$.

Por fim, a identificação da garantia com o princípio da razoabilidade foi um ponto positivo, especialmente tendo em vista que o desenvolvimento do princípio em outros países, já há algum tempo, levou a uma riqueza conceitual, o que possibilitará, por certo, a sua operacionalização de uma maneira mais segura, como adiante se verá.

Ainda melhor teria sido a opção pelo uso do termo "prazo razoável para a duração do processo", que é o mesmo utilizado pela Convenção Americana sobre Direitos Humanos (Pacto de São José da Costa Rica). De acordo com PASTOR, este é,

\footnotetext{
${ }^{124}$ Grifado.
}

125 “A título de exemplo podem ser referidos os julgamentos de traficantes na China e outros países orientais, onde o réu não possui tempo para articular sua defesa, a sentença é imediata e não há tempo para recurso, eis que a pena - normalmente capital - deve ser executada imediatamente. O procedimento, desde a prisão até o fuzilamento dura em média 40 dias" (Gilberto Thums, "Sistemas processuais penais e a questão do tempo - a EC 45/2004 e o prazo razoável do processo". In: Andrei Zenkner Schmidt (coord.), Novos rumos do Direito Penal contemporâneo - livro em homenagem ao Prof. Dr. Cezar Roberto Bitencourt, Rio de Janeiro, Lumen Juris, 2006, p. 286).

126 “O caso mais recente é a reedição do Decreto de instalação de tribunais militares para julgamento de criminosos de guerra ou terroristas nos Estados Unidos. Era utilizado para julgamento de nazistas que haviam invadido o território americano durante a $2^{\mathrm{a}}$ Guerra Mundial. Agora o Presidente George W. Bush valeu-se do mesmo instrumento legal para reduzir direitos de acusados de terrorismo, visto que o julgamento da Corte Militar é sumário e não há direito a recurso" (Op. cit., p. 286).

127 "Quando o fator tempo é o traço marcante de um processo, tem-se um sistema autoritário e desumano" (Op. cit., p. 286). 
efetivamente, o melhor termo do ponto de vista técnico, porque se utiliza de um conceito de maior especificidade, que é o conceito de $\operatorname{prazo}^{128}$, que minimiza a indefinição da garantia. Além do que, apresenta este termo a vantagem de impor ao legislador a fixação de um prazo para o término da persecução penal, diminuindo a insegurança na aplicação subjetiva da garantia por parte dos juízes.

A Emenda Constitucional $n^{\circ} 45$ assegura a razoável duração do processo, não só o de natureza penal, mas de qualquer processo, cível, trabalhista, administrativo, etc. Por isso, a opção pela expressão "razoável duração do processo". Mas para o âmbito do processo criminal, a melhor nomenclatura deve ser "garantia da razoável duração da persecução criminal" ${ }^{129}$, dado que a garantia alcança dois momentos distintos, tanto da investigação criminal, quanto da ação penal ${ }^{130}$, evitando-se a idéia limitativa que a expressão "processo" pode transparecer, no sentido de restringir a incidência da garantia apenas ao processo judicial de conhecimento, isto é, à ação penal, descuidando-se da fase investigativa, que igualmente está abrangida pela norma, uma vez que ela se estende expressamente ao âmbito judicial e ao administrativo. Com a referência à incidência da garantia também ao âmbito do processo administrativo, não pode haver dúvida de que existe limite para a duração da investigação criminal, que não pode se estender indefinidamente ${ }^{131}$.

\footnotetext{
128 "Dentre todas as [nomenclaturas] equivalentes, a que apresenta melhor técnica, a saber, é a que prescreve o direito do acusado a ser julgado dentro de um prazo razoável, pois ela, apesar de uma inevitável textura aberta própria de toda regulação de direitos fundamentais, brinda, pelo menos em parte, uma insuperável precisão ao estabelecer a idéia de prazo, conceito determinado com toda a exatidão pela metodologia do direito processual penal". Cf. Daniel Pastor, "Acerca del derecho fundamental...", cit., p. 214. Colchetes acrescentados para conferir sentido à citação.

${ }^{129}$ Esta é a nomenclatura adotada por Rogério Lauria Tucci, na obra Direitos e garantias individuais.... cit., p. 249, que a intitula "garantia do término da persecução penal em prazo razoável": "Outra garantia que se encarta no devido processo penal é a referente ao desenrolamento da persecutio criminis em prazo razoável". ${ }^{130}$ No sentido de que a persecutio criminis engloba duas fase distintas, um judicial e uma extra-judicial preparatória, ver Frederico Marques, Elementos de direito processual penal, Rio de Janeiro, Forense, 1961, p. 130; Fernando da Costa Tourinho Filho, Processo Penal, vol. 1, São Paulo, Saraiva, p. 193; Sérgio Marcos de Moraes Pitombo, Inquérito policial: novas tendências, CEJUP, Belém, 1987, p. 18.

${ }^{131}$ Cf. a respeito as considerações feitas por Aury Lopes Jr. e Gustavo Henrique Righi Ivahy Badaró, op. cit., p. 91: "Ao assegurar a razoável duração tanto no âmbito judicial como (e a conjunção 'e' é aditiva) também no âmbito administrativo, a Constituição coloca como dies a quo a abertura do inquérito policial".
} 


\section{DIFICULDADES NA APLICAÇÃO E EFETIVAÇÃO DA GARANTIA DA RAZOÁVEL DURAÇÃO DA PERSECUÇÃO PENAL}

As principais dificuldades relacionadas à aplicação e à efetivação da garantia da razoável duração do processo residem na imprecisão dos conceitos envolvidos em sua nomenclatura. Para se definir o momento em que um processo extrapola em sua duração o limite tolerável da razoabilidade, com a conseqüente violação da garantia prevista no artigo $5^{\circ}$, inciso LXXVIII, é preciso lidar com duas noções muito vagas e imprecisas: a de razoabilidade, com conotação plurívoca e que propicia um leque interpretativo muito vasto, e a de prazo, que, embora se sirva, a princípio, de conceito bem definido $^{132}$, apresenta dificuldades para a fixação dos termos inicial e final para a sua contagem.

Considerando que o direito a ser julgado num prazo razoável deve ser assegurado de forma imediata pelo Judiciário, independentemente de lei regulamentando a

132 “O prazo de um ato é uma distância temporal entre marcos representados por dois atos ou fatos processuais, em que um deles assinala o início do prazo (dies a quo) e outro representa o encerramento (dies ad quem)" (Antonio Scarance Fernandes, Processo Penal Constitucional, $3^{\mathrm{a}}$ ed., São Paulo, Revista dos Tribunais, 2002, p. 116). 
aplicação da garantia, cabe a cada juiz a difícil tarefa de desenvolver uma atividade integrativa, analisando em cada caso concreto se houve ou não excesso na duração do processo, servindo-se, para tanto, de mecanismos muito fluidos de controle.

O risco que há na vagueza conceitual da garantia da razoável duração do processo repousa na vocação que expressões com a característica da indeterminação têm de serem utilizadas como standarts ou topoi jurídicos, ou seja, fórmulas carregadas de emotividade empregadas como "curingas" na motivação de decisões judiciais, conferindolhes aparente legitimidade, sem a necessidade de exposição clara dos motivos condutores da decisão.

É por esta razão que se reconhece a necessidade de delimitação conceitual, com o estudo de alguns critérios postos a serviço do juiz para restringir a margem de discricionariedade e auxiliar a interpretação judicial, minimizando a adoção de critérios próprios, e a solução discrepante em situações assemelhadas.

\subsection{Necessidade de delimitação conceitual}

\subsubsection{Risco de utilização da expressão “prazo razoável” como conceito standart ou topos jurídico}

A delimitação de significado da garantia da "razoável duração do processo" traz grande dificuldade, seja pela incerteza dos momentos iniciais e finais de sua aferição, seja pela extrema vagueza da noção de razoabilidade.

Diante de tal incerteza semântica, há grande risco de que a garantia da razoável duração do processo seja utilizada não como uma garantia, mas como um standart 
jurídico ${ }^{133}$, isto é “como uma técnica retórica, apta a tornar certa decisão mais persuasiva e legítima" $" 134$.

OLIVEIRA alerta para a necessidade de se fugir do tratamento conceitual do princípio da razoabilidade a partir da noção de standart jurídico. Neste sentido: “Os standarts (definidos como 'medida média de conduta social correlata'), diferenciando-se das demais categorias, apresentam os seguintes caracteres: (i) todos envolvem um certo julgamento moral da conduta humana; (ii) sua aplicação não demanda um conhecimento jurídico exato, mas um senso comum sobre as coisas rotineiras (common sense about common things) ou uma intuição treinada sobre coisas que fogem da experiência do aplicador; (iii) não são formulados em absoluto com um certo conteúdo, seja pelo legislador, seja pelo juiz, na medida em que variam em função do tempo, lugar e circunstâncias do caso em que são aplicados"135.

A utilização da razoabilidade como standart é observável na análise da jurisprudência brasileira. $\mathrm{Na}$ ausência de parâmetros fixados pelo legislador infraconstitucional, como era de se esperar, a razoabilidade tem sido utilizada de forma bastante aberta pelos juízes, tal qual um standart ou, ainda, como um topos, que varia de julgador para julgador, com o risco sempre presente de ser empregada como instrumento de

133 Cf. Marcelo José Magalhães Bonicio, Proporcionalidade e processo: a garantia constitucional da proporcionalidade, a legitimação do processo civil e o controle das decisões judiciais, São Paulo, Atlas, 2006, pp. 33 a 34: "Em suma, tanto o princípio da razoabilidade quanto o da proporcionalidade estão inseridos no conceito standart, isto é, são termos fluidos que servem de sustentação jurídica para hipóteses em que não há regra específica para regular uma determinada situação".

${ }^{134}$ Cf. José Roberto Pimenta Oliveira, Os Princípios da razoabilidade e da proporcionalidade no Direito Administrativo brasileiro, São Paulo, Malheiros, 2006, p. 166. Ainda neste mesmo sentido, afirma o autor: "Neste prisma, a função de persuasão do standart se justifica como meio de suscitar adesão, tornando a decisão aceitável, de tal sorte que se constitui em meio de solução de problemas de comunicação jurídica. A função de legitimação também é enaltecida, ao lado da função de generalização, na medida em que impõe sua observância nas diversas situações similares...”, op. cit., p. 164.

135 Idem, p. 164. O mesmo autor cita como exemplos de standarts jurídicos, relativos ao princípio da razoabilidade, no âmbito administrativo, os seguintes termos: "antecedência razoável", "nível razoável de importação", "nível razoável de proteção efetiva", "dúvida razoável para abertura de sindicância”, "vigilância razoável sobre uma aeronave", "lucro razoável em transporte aéreo", "caráter razoável das tarifas", "uso de qualquer outro método razoável", "acesso razoável para inspeções", "vedação de gastos acima do razoável”, "prazo razoável para ouvir os acusados", "prazo razoável para iniciar ou concluir obras”, "co-participação razoável nos lucros de exploração", "abatimento razoável no preço de energia", "lucro razoável na concessão", "custo de serviço razoável”, "extensão razoável de certa zona”, "motivo razoável para realizar uma inspeção", "segurança razoável de operação de crédito rural", "assistência razoável ao turismo", "medidas contra corrupção com razoável nível de detalhe", "razoável duração dos processos administrativos", "início razoável de prova material”, "coeficiente de utilização razoável da capacidade para atender às necessidades atuais e às razoavelmente previsíveis para o transporte de passageiros e carga", etc. (Idem, p. 174). 
argumentação para justificar o excesso de prazo, especialmente quando se trata de crimes mais graves.

A ausência de critérios acaba levando à situação de que uma mesma hipótese seja tratada de maneira conflitante e até mesmo oposta em cada caso concreto. E, assim, a falta de coerência das decisões judiciais afeta a própria consistência da participação da população no processo democrático, limitando o acesso e o controle público das razões utilizadas pelo Judiciário para a tomada de decisões.

FREITAS FILHO faz interessante transposição do conceito de accountability, que remonta ao controle do exercício do poder legislativo, de acordo com o qual os ocupantes de cargos públicos devem se pautar por regras pré-estabelecidas, conhecidas de antemão pela sociedade, e de forma coerente, para o âmbito do Poder Judiciário. Para o autor, o Judiciário, a quem cabe a própria função de controle de legalidade do exercício do poder pelos demais poderes, deve, ele próprio, adequar-se às regras da coerência e da transparência, fundamentando todas as decisões de acordo com as regras e princípios inerentes à sua atividade, possibilitando um controle de legitimidade pela população ${ }^{136}$.

A grande dificuldade para que as decisões judiciais sobre a razoável duração de um processo sejam coerentes entre si reside na própria margem de discricionariedade para o preenchimento do conteúdo do conceito. Situações processuais análogas podem ser tratadas de maneira díspares dependendo do julgador, da concepção que este tem do que pode ser considerado razoável em termos de duração de um processo. Não é desconhecido de ninguém que cada juiz possui dentro de si toda uma carga valorativa, concepções políticas e religiosas próprias, bem como história de vida e experiência prática distinta, que inevitavelmente influencia a sua decisão.

Não é de se excluir, ainda, que questões relativas ao próprio mérito da causa possam influenciar decisões conflitantes, ainda que a demora seja quantitativamente a mesma, e que os processos apresentem os mesmos incidentes processuais e as mesmas

\footnotetext{
${ }^{136}$ Conferir, nesse sentido, Roberto Freitas Filho, "Estudos Jurídicos Críticos (CLS) e coerência das decisões", Revista de Informação Legislativa, ano 44, nº 175, julho-setembro de 2007, Brasília, p. 42: "Espera-se de um judiciário democrático e independente que seja imparcial e que as decisões proferidas observem o critério da racionalidade de suas fundamentações. Assim, um mesmo tribunal não deve proferir decisões conflitantes ou sem sentido. O judiciário não pode exercer seu poder de forma a decidir conflitos jurídicos em desrespeito á lógica, em inobservância de fatos relevantes nem distorcendo fatos. A noção de accountability é, portanto, um antídoto em relação ao arbítrio e tem como pressuposto o fato de que o judiciário possui enorme poder e deve ser publicamente responsável (no sentido de responsivo, accountable) pela forma como o utiliza".
} 
dificuldades procedimentais. A gravidade do crime ou, ainda, as circunstâncias em que o crime foi cometido, por exemplo, são fatores que podem levar a um maior rigor no reconhecimento do excesso de prazo $^{137}$, ainda que se esteja diante de um prazo estendido e injustificável do ponto de vista processual.

A existência de julgados no âmbito do Supremo Tribunal Federal repisando que "a alegada gravidade da imputação não obsta o direito subjetivo à razoável duração do processo (inciso LXXVIII do art. $5^{\circ}$ da CF)" ${ }^{138}$ é indicativo de que há alguma freqüência na invocação da gravidade do crime como fator de justificação do excesso de prazo.

No julgamento do habeas corpus $\mathrm{n}^{\mathrm{0}} 89622^{139}$, esta problemática veio à tona de maneira muito cristalina. O relator Ministro Carlos Britto se questiona se a gravidade da imputação que recai sobre o paciente, no caso um roubo triplamente qualificado, teria a força de "coonestar o desmesurado prazo de 3 anos de custódia cautelar", ao que acaba respondendo negativamente, afirmando que a redução das garantias penais clássicas não pode ser utilizada como um mecanismo de "eficiência" do sistema penal repressivo".

Não se pretende defender, neste estudo, que se restrinja o poder interpretativo ou criativo dos juízes. Mas a existência de parâmetros legais, mais objetivos, sem dúvida traria maior coerência às decisões judiciais acerca da duração do processo, na

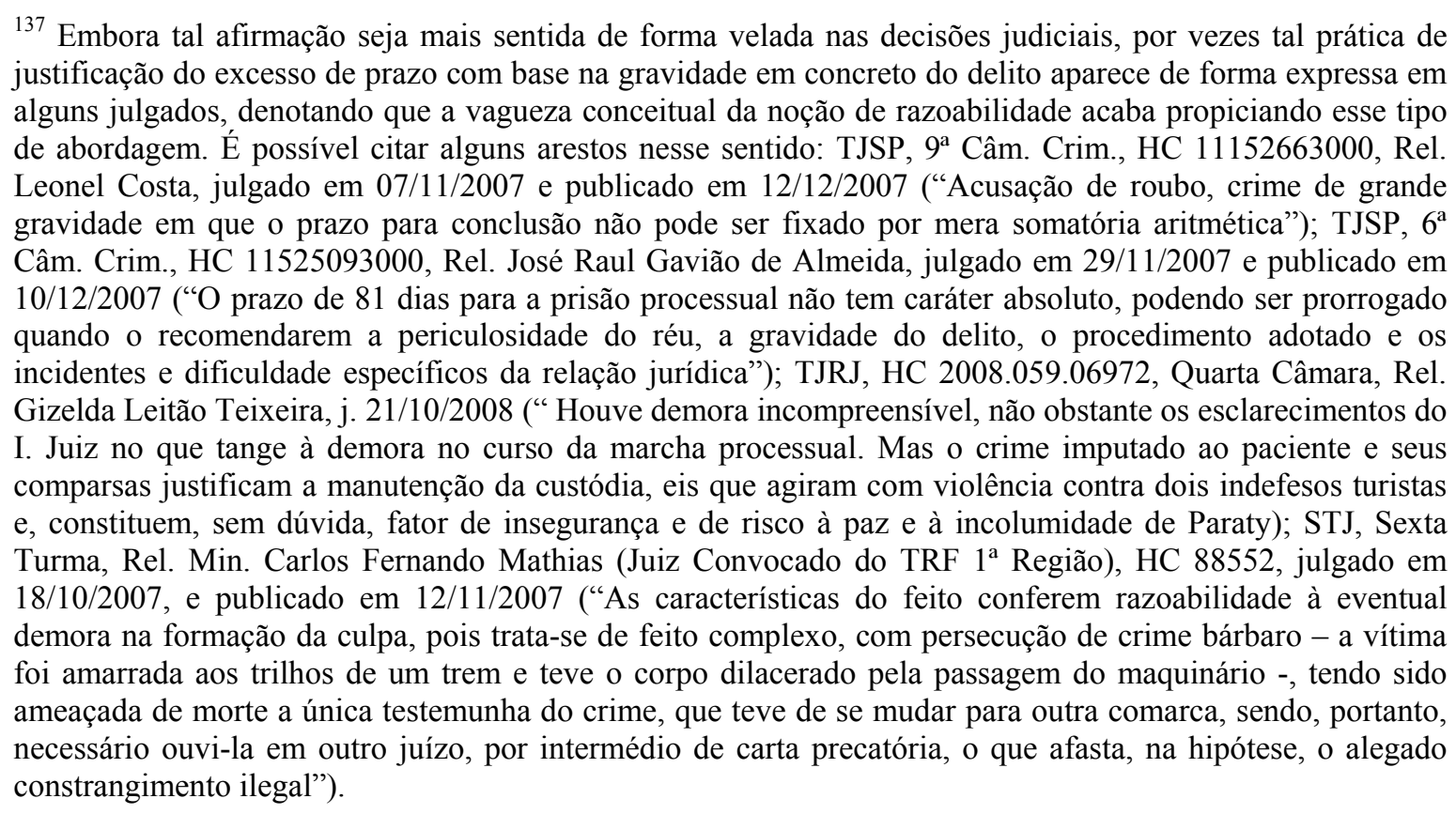

${ }^{138}$ Conferir, nesse sentido, os seguintes julgados do Supremo Tribunal Federal: HC 89622/BA, Primeira Turma, Rel. Min. Carlos Britto, j. 03/06/2008, DJ de 18/09/2008; HC 93786/ES, Primeira Turma, Rel. Min. Carlos Britto, j. 17/06/2008, DJ de 30/10/2008; HC 93523/SP, Primeira Turma, Rel. Min. Carlos Britto, j. 29/04/2008, DJ de 16/10/2008.

${ }^{139}$ HC 89622/BA, Primeira Turma, Rel. Min. Carlos Britto, j. 03/06/2008, DJ de 18/09/2008. 
medida em que possibilitaria um fio condutor para a interpretação judicial e para a sua adequada fundamentação, e viabilizaria maior controle por parte da sociedade.

\subsubsection{Risco de utilização da expressão “razoável” como mecanismo de justificação ou legitimação do excesso}

Constata-se, como já afirmado, uma forte tendência de utilização da noção de razoabilidade, e, bem assim, da máxima da proporcionalidade, como meio de viabilizar uma maior restrição de direitos e garantias individuais. Com fundamento na ponderação de interesses, tem-se advogado a idéia de que é possível uma flexibilização das garantias individuais para que se alcance um fim maior que, no âmbito do processo penal, tem sido apontado como o a concretização do dever de punir do Estado.

Nenhuma concessão pode ser feita, em detrimento de qualquer garantia fundamental que seja, em nome de se alcançar o fim da imposição da pena, pois assim se estaria inviabilizando a concretização de outro fim igualmente importante do processo, que é assegurar os direitos e garantias individuais do acusado em face do Estado.

FABIANA L. Z. DO PRADO, em obra específica sobre a ponderação de interesses no processo penal, lucidamente pondera ter havido uma distorção no uso do princípio da proporcionalidade, que tem sido muitas vezes invocado, por conta de sua vagueza semântica, como um fator de legitimação de movimentos tendentes a reduzir a eficácia de direitos e garantias fundamentais ${ }^{140}$.

$\mathrm{O}$ argumento central que tem servido de base para tal deturpação reside na necessidade de proteção de bens jurídicos coletivos de conteúdo impreciso, como a paz social, a segurança pública, o interesse social, entre outros, o que leva a uma aparência de justa ponderação de bens ${ }^{141}$, a ensejar a aplicabilidade do princípio da proporcionalidade,

\footnotetext{
${ }^{140}$ Fabiana Lemes Zamalloa do Prado, A ponderação de interesses em matéria de prova no processo penal, São Paulo, IBCCrim, 2006, p. 200: “A invocação ideológica do princípio da proporcionalidade tem constituído a válvula de escape das agências judiciais, principalmente do Poder Judiciário e do Ministério Público, para atender aos reclamos do movimento 'da lei e da ordem', acolhidos pelo senso comum, com a aparência de que atuam de acordo com a sua finalidade constitucional, fulminando, assim, dia a dia, a eficácia dos direitos e garantias tão duramente conquistados ao longo da história".

${ }^{141}$ A mesma tendência é observada também por Fábio Bittencourt Rosa, em "Proporcionalidade: perigo do conceito aberto", Boletim do IBCCrim no 153, agosto de 2005, São Paulo, p. 5: "Na época atual, de insegurança inquestionável e de uma criminalidade sofisticada, quase imune à jurisdição, preconiza-se um questionamento dos direitos e garantias individuais. Por tal modo, quando se evidencia situação que põe em
} 
quando, na realidade, o que se está a autorizar é o sacrifício de direitos fundamentais por uma via transversa.

Criado como barreira de proteção contra o excesso de poder do Estado ${ }^{142}$, como mecanismo que limita a restrição de direitos fundamentais, o princípio de proporcionalidade tem sido usado para o fim exatamente oposto, de legitimação de maior restrição a estes mesmos direitos ${ }^{143}$.

Por esta razão é que toda e qualquer interpretação judicial que se utilize da idéia de razoabilidade deve levar em consideração o princípio da dignidade da pessoa humana. Como bem ressaltado por LOPES JR., "o princípio da razoabilidade (ou proporcionalidade, aqui não estamos adotando a distinção feita por parte da doutrina) por sua abertura conceitual deve, no processo penal, estar necessariamente conectado ao princípio da dignidade da pessoa humana"144.

A análise do que seja razoável ou não, justamente por conta da fluidez apresentada pelo próprio conceito de razoabilidade, revela-se naturalmente calcada em certa dose de subjetivismo, enquanto critério de interpretação destinado à atividade jurisdicional $^{145}$. É certo que a decisão judicial, até mesmo por conta da necessidade de motivação, deverá permanecer limitada a um âmbito de argumentação, que impõe certa racionalidade, mas isto não retira completamente a insegurança gerada pela falta de limitação temporal à duração do processo.

O princípio da proporcionalidade, com adiante será estudado ${ }^{146}$, alcança dois níveis distintos: o âmbito da elaboração legislativa e âmbito judicial.

perigo a ordem, a segurança, a economia, a saúde pública ou o meio ambiente, põe-se o julgador a apreciar no cotejo de interesses qual o preponderante, ou seja, se o interesse coletivo ou a garantia individual. A proporcionalidade, diante disso, caracteriza-se como critério limitador do gozo dos direitos fundamentais".

${ }^{142}$ Marcelo José Magalhães Bonicio, op. cit., p. 14.

${ }^{143}$ Fabiana Lemes Zamalloa do Prado, op. cit., p. 199.

144 Aury Lopes Jr., Direito processual penal e sua conformidade constitucional, volume I, $3^{\mathrm{a}}$ ed., Rio de Janeiro, Lumen Juris, 2008, p. 147.

145 “Assim, a percepção dos limites da razoabilidade é algo que emerge mais do conhecimento intuitivo, derivado de uma sensação de desproporção ou de impropriedade que a apreensão de um objeto ocasiona, do que do conhecimento intelectual, obtido mediante operações ou raciocínios complexos. Contudo, muito embora a percepção do irrazoável seja de imediato apreendida, pura e simplesmente, sem processos intelectuais de justificação ou argumentação", cf. Irene Patrícia Nohara, Limites à razoabilidade nos atos administrativos, São Paulo, Atlas, 2006, p. 2.

${ }^{146}$ Ver, a respeito, o capítulo 4, infra. 
No campo legislativo, deverão ser fixados prazos máximos de duração para um julgamento definitivo, de acordo com critérios que atendam ao princípio da proporcionalidade. Levando um exemplo ao extremo para que seja melhor compreendida a situação de que se trata, o legislador não poderá fixar um prazo de duração do processo que supere o maior prazo de prescrição previsto no Código Penal, ou seja vinte anos, pois isto contrariaria toda a sistemática processual, mostrando-se absolutamente desproporcional.

No campo judicial, o princípio da proporcionalidade funciona como um controle de constitucionalidade difuso (ou, ainda, concentrado, pelo Supremo Tribunal Federal, com a retirada da norma do ordenamento jurídico), verificando se a norma obedeceu a uma justificação constitucional para a sua criação e se atende, de maneira abstrata, aos critérios da adequação, necessidade e proporcionalidade em sentido estrito. Cabe ao juiz, ainda, no momento da aplicação da lei, verificar a razoabilidade da duração do processo no caso concreto, sempre levando em consideração que, no processo penal, ainda maior proteção deve ser conferida aos direitos fundamentais ${ }^{147}$.

Suponhamos um caso em que o legislador fixe o prazo máximo de duração do processo em dois anos, mas, no caso concreto, sem qualquer complexidade, seja verificada uma demora injustificada para a realização de um único ato, como a prolação da sentença, por exemplo. Ainda que se esteja dentro do prazo globalmente estabelecido, irrazoável se mostra a demora no caso concreto, cabendo ao juiz o seu reconhecimento e a sua correção.

Impõe-se, portanto, o estudo do princípio da proporcionalidade e da razoabilidade, de forma buscar nestes dois conceitos parte essencial do conteúdo da garantia da razoável duração do processo. Trata-se de relevantes ferramentas hermenêuticas, que fornecerão elementos muito úteis à análise acerca do que pode ser

\footnotetext{
${ }^{147}$ Conferir, a respeito de como se faz a aplicação do princípio da proporcionalidade no âmbito judicial, Maurício Zanoide de Moraes, Presunção de inocência.... cit., p. 345: "No plano abstrato, a importância do controle constitucional das leis no plano abstrato, a importância do controle de constitucionalidade das leis pela proporcionalidade se mostra relevante para o âmbito processual penal, no tocante à necessidade de controle da (in)constitucionalidade da legislação pelo julgador. Assim, de mod difuso ou concentrado, muitas vezes o Judiciário deverá se pronunciar sobre eventual falta de justificação constitucional de uma lei, afastando sua incidência ao caso concreto ou, se for reconhecida sua inconstitucionalidade de forma concentrada, declarar sua retirada do ordenamento jurídico. Isso ocorre porquanto o Judiciário, ao analisar o sopesamento feito pelo legislador para a elaboração do texto legal, dele (sopesamento) diverge e, portanto, entende-o (texto legal) sem justificação constitucional.

O plano concreto, contudo, é o de maior ocorrência prática para a área processual penal. Nesse âmbito, deverá o julgador examinar a proporcionalidade da aplicação de uma lei, sobre a qual já se tenha feito o primeiro controle (em nível abstrato). Assim, mesmo uma lei com justificação constitucional poderá, no caso concreto, mostrar-se desproporcional devido a sua aplicação ser abusiva ou excessiva. Por essa razão a proporcionalidade também é denominada "proibição do excesso"”.
} 
considerado, ou não, um prazo razoável de duração de um determinado processo, conferindo maior segurança na aplicação da garantia em questão, e tornando mais palpável o seu significado e alcance em cada caso concreto.

\section{NOÇÃO DE RAZOABILIDADE: RECURSO AOS PRINCÍPIOS DA PROPORCIONALIDADE E DA RAZOABILIDADE}

Os princípios da razoabilidade e da proporcionalidade desenvolveram-se num contexto de necessidade de delimitação do poder estatal em face dos direitos fundamentais. De acordo com SUZANA DE TOLEDO BARROS, a história do princípio da proporcionalidade (e da razoabilidade, pois a autora admite a equivalência entre os dois conceitos) "acompanha a história da defesa dos direitos fundamentais e vai surgir como decorrência da passagem do Estado de Polícia para o Estado de Direito, quando é formulado com o intuito de controlar o poder de coação do monarca, chamado de poder de 
polícia, porque ilimitado quanto aos fins que poderia perseguir e quanto aos meios que poderia empregar" ${ }^{148}$.

Nesse contexto, tiveram grande importância as teorias jusnaturalistas que, a despeito de refletirem um tipo de liberdade arraigado à realidade da burguesia ${ }^{149}$, lograram dar embasamento teórico à existência de valores inerentes ao ser humano, persistentes mesmo em face do monarca.

Com raízes na lei do talião, no Código de Hamurabi, na Lei das XII Tábuas e até mesmo na Bíblia, o princípio da proporcionalidade só foi desenvolvido enquanto princípio jurídico suprapositivo a partir das obras iluministas do século XVIII, quando ganhou grande impulso ${ }^{150}$. No final do século XVIII e início do século XIX foi acolhido pelo Direito Administrativo como parte do direito de polícia, isto é, como medida destinada a regular as restrições do Poder Executivo na esfera de direitos dos indivíduos. ${ }^{151}$

Especialmente no contexto do pós-Guerras, constatou-se com maior premência a necessidade de fixar alguns critérios para a restrição de direitos fundamentais, extrapolando uma leitura meramente positivista do ordenamento jurídico. Principalmente na Alemanha, verificou-se, com o nazismo, a completa incapacidade do modelo de Estado de Direito em conter a atuação indiscriminada do Estado na esfera de direitos individuais.

Assim, surgiram, em diversos países, a partir desta mesma proposta, alguns critérios a serem obedecidos pelos três Poderes do Estado, Legislativo, Executivo e Judiciário, para a restrição de direitos fundamentais ${ }^{152}$.

Importa, portanto, verificar como alguns países desenvolveram esta mesma idéia de restrição ao poder estatal, de modo a buscar uma formulação teórica básica que

${ }^{148}$ O princípio da proporcionalidade e o controle de constitucionalidade das leis restritivas de direitos fundamentais, $3^{\text {a }}$ ed., Brasília, Brasília Jurídica, 2003, p. 37.

149 "Sabe-se que a liberdade a que se reportavam os filósofos jusnaturalistas era aquela da classe burguesa, por isso mesmo expressada na liberdade pessoal, na liberdade de contratar e comerciar e na propriedade privada" (Suzana de Toledo Barros, op. cit., p. 38).

${ }^{150}$ Mariângela Gama de Magalhães Gomes, O princípio da proporcionalidade no Direito Penal. Revista dos Tribunais, São Paulo, 2003, pp. 40-52.

${ }^{151}$ Cf. J. J. Gomes Canotilho, op. cit., s./d., pp. 266-267.

152 "La proporcionalidad como principio supone el ejercicio razonable del poder político en tanto eficaz para la realización de las exigencias del bien común, integrando y respetando los derechos fundamentales de los ciudadanos". Em tradução livre: "A proporcionalidade como princípio supõe o exercício do poder político para a efetivação das exigências de bem comum, integrando e respeitando os direitos fundamentais dos cidadãos". Cf. Guilherme Jorge Yacobucci, "El principio de proporcionalidad como regla fundamental de la politica criminal", Andrei Zenkner Schmidt (coord.), Novos rumos do Direito Penal contemporâneo livro em homenagem ao prof. Dr. Cezar Roberto Bitencourt, Rio de Janeiro, Lumen Juris, 2006, p. 91. 
possa servir à compreensão do que pode ser considerado como razoável relativamente à garantia da razoável duração do processo.

\subsection{Desenvolvimento dos princípios da razoabilidade e da proporcionalidade nos principais países}

\subsubsection{Alemanha}

$\mathrm{Na}$ Alemanha, o princípio da proporcionalidade decorre do Estado Democrático de Direito, ou seja, da idéia de que os direitos fundamentais, como expressão do livre desenvolvimento da personalidade dos cidadãos frente ao Estado, não podem ser limitados pelo Poder Público mais do que seja estritamente necessário para a proteção dos interesses públicos ${ }^{153}$. Trata-se de princípio decorrente do fundamento do Estado Democrático de Direito, que é a dignidade da pessoa humana.

O modelo do "Estado de Direito", baseado em uma concepção ideológica liberal e fundada na submissão do governo ao império das leis ${ }^{154}$, mostrou-se suscetível a abusos por parte do Estado.

Outro modelo de Estado que se buscou implementar foi o "Estado Social de Direito", fundado na idéia de que o Estado deveria atuar para o pleno desenvolvimento de direitos sociais e econômicos ${ }^{155}$, que igualmente foi superado, por não ter tido êxito no combate à desigualdade social. A Constituição de Weimar (1919), que surgiu exatamente no contexto de positivação de direitos fundamentais, e a partir de uma preocupação de reconhecimento de direitos de segunda geração, acabou trazendo cunho marcadamente intervencionista ao Estado alemão, permitindo o desenvolvimento do nacional socialismo e a violação sistemática de direitos fundamentais de maneira legitimada em nome da

\footnotetext{
${ }^{153}$ Cf. Juan Cianciardo, El principio de razonabilidad - del debido proceso sustantivo al moderno juicio de proporcionalidad, Buenos Aires, Ábaco de Rodolfo Desalma, 2004, p. 55.

${ }^{154}$ Cf. José Afonso da Silva, Curso de Direito Constitucional Positivo, $18^{\mathrm{a}}$ ed., São Paulo, Malheiros, 1998, p. 116 .

${ }^{155}$ Antonio Enrique Pérez Luño, op. cit., p. 234.
} 
preservação de valores coletivos como a preservação do "são sentimento alemão" e o “progresso" do país ${ }^{156}$.

Surgiu, então, o modelo do "Estado Democrático de Direito", com fundamento na dignidade da pessoa humana e no pluralismo político, e que buscou sua legitimação em seu embasamento democrático. Este foi o modelo adotado pela Constituição da República Federativa do Brasil de 1988, nos termos de seu artigo $1^{\text {o157}}$.

O princípio da proporcionalidade somente passou a integrar a Constituição da Alemanha após a Segunda Guerra Mundial, quando se constatou a fragilidade do sistema jurídico positivista diante do nazismo e do fascismo ${ }^{158}$. A Alemanha passou, então, a adotar a dignidade da pessoa humana e o pluralismo político como fundamentos, ou valores fundantes, do Estado Democrático de Direito ${ }^{159}$, limitadores da ingerência estatal sobre o indivíduo ${ }^{160}$.

Mesmo antes do contexto do pós-Segunda Guerra, a idéia de que o Poder do Estado deveria ser limitado frente ao indivíduo já existia na Alemanha sob uma perspectiva

156 “(...) o nacional-socialismo transformou a Alemanha em comunidade rácica e corrompeu a Constituição de Weimar, levando à ditadura do Führer, que legou ao povo alemão a dolorosa experiência da Segunda Grande Guerra, mostrando que a positivação de um bem elaborado catálogo de direitos não é suficiente para amparar esses mesmos direitos" (Suzana de Toledo Barros, op. cit., p. 47).

157 “A República Federativa do Brasil, formada pela união indissolúvel dos Estados e Municípios e do Distrito Federal, constitui-se em Estado Democrático de Direito e tem como fundamentos: I - a soberania; II - a soberania; III - a dignidade da pessoa humana; IV - os valores do trabalho e da livre iniciativa; V - o pluralismo político".

${ }^{158}$ Cf. Marcelo José Magalhães Bonicio, op. cit., p. 48. No mesmo sentido, José Roberto Pimenta Oliveira, op. cit., p. 48: "As vicissitudes históricas bem explicam porque, no direito alemão, o princípio da proporcionalidade tem seu vínculo de legitimação constitucional construído e afirmado a partir da noção de Estado de Direito e dos direitos fundamentais (tão vilipendiados diuturnamente durante o regime nazista), após a restauração do regime constitucional democrático, com o encerramento da Segunda Guerra Mundial".

${ }^{159}$ Em seu artigo $1^{\circ}$, nº1, a Lei Fundamental da República Federal da Alemanha assim dispõe: “A dignidade humana é inviolável. Respeitá-la e protegê-la é obrigação do Poder Público”, tradução livre do espanhol, Ley Fundamental para la República Federal de Alemania, Departamento de Prensa e Información Del Gobierno Federal, p. 48.

${ }^{160} \mathrm{E}$, seguindo o exemplo alemão, muitas foram as Constituições do pós-Guerra que adotaram a dignidade da pessoa humana como fundamentos do Estado Democrático de Direito. Assim, a Constituição portuguesa (“Art. $1^{\circ}$ Portugal é uma República soberana, baseada na dignidade da pessoa humana e na vontade popular e empenhada na construção de uma sociedade livre, justa e solidária”), a Constituição espanhola (“Art. 10. A dignidade da pessoa, os direitos invioláveis que lhe são inerentes, o livre desenvolvimento da personalidade, o respeito à lei e aos direitos dos demais são fundamentos da ordem política e da paz social"), a Constituição francesa (Preâmbulo: "No dia seguinte à vitória obtida pelos povos livres sobre os regimes que têm tratado de submeter e degradar s pessoa humana, o povo francês proclama novamente que todo ser humano, sem distinção de raça, de religião nem, de crença, possui direitos inalienáveis e sagrados"). Na Constituição brasileira de 1988 o mesmo valor é erigido como fundamento da República ("Art. 1: A República Federativa do Brasil, formada pela união indissolúvel dos Estados e Municípios e do Distrito Federal, constitui-se em Estado Democrático de Direito e tem como fundamentos: III - a dignidade da pessoa humana"). 
de verificação da indispensabilidade dos meios para o atingimento dos fins buscados pelo Estado. Mas a noção de proporcionalidade, que já se encontrava presente em algumas obras do final do século XVIII, que tratavam do poder de polícia no direito prussiano, limitava-se à idéia de necessidade, que mais tarde passaria a integrar um dos critérios do princípio da proporcionalidade ${ }^{161}$. Na jurisprudência, da mesma forma, já se verificava a aplicação tímida da noção de necessidade ${ }^{162}$.

Foi com a Lei Fundamental de Bonn (1949), todavia, que a proporcionalidade ganhou terreno. Trata-se de norma constitucional não escrita, decorrente do conceito de Estado de Direito ${ }^{163}$, a partir do qual visou o constituinte viabilizar um controle de legitimação do exercício do poder, que deveria ser realizado apenas na medida necessária para a consecução dos objetivos da República, sem uma restrição indevida na esfera de direitos dos cidadãos.

O princípio da proporcionalidade começou, então, a ganhar os contornos atualmente conhecidos ${ }^{164}$, partindo da idéia de que o Estado deve proporcionar condições

161 “O princípio da proporcionalidade, tal como estruturado na atualidade, encontra suas raízes, no direito alemão, na exigência de necessidade ou de indispensabilidade dos meios, já observada no direito prussiano de polícia do final do século XVIII. A doutrina assinala alusões à proporcionalidade na obra de Scheidemantel (Das allgemeine Staatsrecht überhaupt und nach der Regierungsform, de 1775) e Rupprecht von Kraus (Handbuch des Teutschen Policeyrechts, de 1799), mas dá especial significado aos ensinamentos de Carl Gottlieb Svarez ao então futuro rei Frederico Guilherme III, em 1712, bem como ao uso da noção de proporcional, como terminus tecnicus da linguagem jurídica, feito por Günter Heinrich von Berg (Handbuch des Teutschen Policeyrechts, de 1802), que a considerava uma limitação aos poderes estatais derivada da relação entre o objetivo da intervenção lesiva e a respectiva medida. A noção surge, assim, na Era Moderna, na esteira da difusão do ideário liberal e superação do absolutismo, traduzidos, no mundo juspublicista pela implantação do Estado de Direito e conseqüente derrocada do Estado de Polícia” (José Roberto Pimenta Oliveira, op. cit., pp. 42 e 43).

162 "Na segunda metade do século XIX, ocorre, primeiramente, a afirmação de necessidade na jurisprudência e na doutrina alemã. Assim, o Tribunal Administrativo Superior Prussiano traz como leading Case, no controle da necessidade de medidas de polícia, o caso Kreuzberg. Julgado em 14.6.1882, nele o Tribunal invalidou ato administrativo de interdição de certo estabelecimento que, sem licença administrativa, comercializava álcool, afirmando a Corte que a autoridade poderia ter adotado um ato menos oneroso para o particular" (Idem, p. 43).

163 "No direito Constitucional alemão, outorga-se ao princípio da proporcionalidade (Verhältnismässigkeit) ou ao princípio da proibição de excesso (Übermassverbot) qualidade de norma constitucional não-escrita, derivada do Estado de Direito" (Gilmar Ferreira Mendes, "O princípio da proporcionalidade na jurisprudência do Supremo Tribunal Federal: novas leituras”, Repertório IOB de Jurisprudência: Tributário, Constitucional e Administrativo, São Paulo, no 14, julho de 2000, p. 365).

${ }^{164}$ Cf. José Roberto Pimenta Oliveira, op. cit., p. 45: “Os anos 50 representam uma nova fase de desenvolvimento dogmático da proporcionalidade. Avança-se no desdobramento ou estruturação interna da máxima, aperfeiçoa-se a terminologia que consubstancia e formaliza sua mensagem deôntica e amplia-se o seu âmbito de aplicação. Com efeito, jurisdição e doutrina começam a diferenciar os três escalões normativos do princípio da proporcionalidade, o que exige o aperfeiçoamento do uso de terminologia. Por outro lado, de mero conceito elevado doutrinariamente à categoria de princípio do direito de polícia (de cujo campo temático migrou para a condição de princípio do direito administrativo), o princípio da proporcionalidade passa, a partir da Lei Fundamental de 1949, à condição de princípio constitucional, impositivo não apenas ao 
adequadas para o livre desenvolvimento da personalidade de cada indivíduo, eximindo-se de qualquer atuação que possa lesionar direitos fundamentais a ponto de atingir a dignidade humana.

Desenvolveu-se gradualmente o conceito, chegando-se à criação de três critérios ${ }^{165}$, úteis à avaliação de legitimidade da medida restritiva de direitos (ou da lei a ser aplicada): a sua adequação, isto é, a sua aptidão para alcançar o resultado buscado; a sua necessidade, isto é, se a medida a ser dotada é realmente necessária para alcançar o resultado ou se existe outra que, sendo menos restritiva, poderia conduzir ao mesmo resultado; e a proporção em sentido estrito, que pressupõe uma ponderação de importância entre o resultado buscado e o direito a ser restringido, levando à idéia de que nem todo o tipo de restrição aos direitos fundamentais pode ser admitida, ainda que seja apta a produzir o resultado e seja a menos gravosa possível ${ }^{166}$.

A Alemanha teve, assim, como bem observado por IRENE P. NOHARA, um papel fundamental no desenvolvimento da noção de ponderação entre as medidas estatais restritivas e os fins buscados ${ }^{167}$, vedando-se o excesso de poder, aquele que ultrapassa os limites da dignidade humana.

A dignidade humana apresenta dois aspectos indissociáveis: uma garantia negativa, de que não haverá ofensa por parte do Estado, e outra positiva, de que o Estado deverá promover condições para o pleno desenvolvimento da personalidade de cada indivíduo. Neste sentido, esclarece PÉREZ LUÑO: "La dignidad humana constituye no

administrativo e juiz, mas ao próprio legislador, alcançando, nas décadas seguintes, a qualidade de princípio de todo direito público tedesco".

${ }^{165}$ De acordo com Mariângela Gama de Magalhães Gomes, op. cit., p. 60, em nota de rodapé de $\mathrm{n}^{\mathrm{o}} 73$, foi a partir de sentença de 11 de junho de 1958 (BverfGE 7, p. 377 (409ss), que a jurisprudência do Tribunal Constitucional alemão reuniu os três critérios, dando origem ao conceito de proporcionalidade tal como hoje é entendido.

166 “O princípio da proporcionalidade, como instituto básico e pressuposto na Constituição, desenvolveu-se no contexto da proteção aos direitos fundamentais. Apareceu na Alemanha como garantia especial traduzida na exigência de que a intervenção estatal nesta esfera se dê de forma adequada, por necessidade e na justa medida, objetivando a máxima eficácia e otimização dos vários direitos fundamentais concorrentes.

Essa idéia se traduz na conhecida fórmula da doutrina e da jurisprudência alemãs: Verhältnismässigkeitsprinzip (princípio da proporcionalidade) $=$ Geeignetkeit (adequação) + Notwendigkeit (ou Erforderlichkeit, necessidade ou exigibilidade) + Verhältnismässigkeit (proporcionalidade em sentido estrito ou legitimidade entre meios e fins)" (Cf. Irene Patrícia Nohara, op. cit., p. 61).

167 “A Alemanha consagrou-se pelo desenvolvimento da técnica de ponderação de bens, que visa a combater os efeitos catastróficos de cláusula gerais permissivas da ação estatal restritiva dos direitos fundamentais. Essa técnica relaciona-se com o Estado de Direito e atualmente predomina no país a visão de que a lei, como instrumento de regulação da vida em sociedade, deve propiciar a existência do indivíduo considerando o maior espaço possível para o desenvolvimento de sua personalidade e garantindo amplas possibilidades de suprir as suas necessidades" (Idem, p. 60). 
solo la garantia negativa de que la persona no va a ser objeto de ofensas o humillaciones, sino que entraña también la afirmación positiva del pleno desarrollo de la personalidad de cada individuo. El pleno desarrollo de la personalidad supone, a su vez, de um lado, el reconocimiento de la total autodisponibilidad, sin interferencias o impedimentos externos, de las posibilidades de actuación propias de cada hombre; de outro, la autodeterminación (Selbstbestimmung des Menschen) que surge de la libre proyección histórica de la razión humana, antes que de una predeterminación dada por la naturaleza"168.

Percebe-se, assim, a relação indissociável entre os direitos fundamentais e a dignidade humana. A dignidade humana constitui o valor básico, o fundamento dos direitos humanos, que são reconhecidos de forma a explicitar e satisfazer as necessidades da pessoa humana ${ }^{169}$.

Há autores que defendem que o excesso de poder refere-se àquele que interfere no núcleo mínimo ou essencial dos direitos fundamentais, obstando, assim, o livre desenvolvimento da personalidade. Nesse sentido: "A proporcionalidade fundamenta-se na idéia de que restrições demasiadas podem aniquilar os direitos restringidos e comprometer a própria noção de Estado de Direito Democrático. O princípio se presta a combater o

\footnotetext{
${ }^{168}$ Antonio Enrique Pérez Luño, op. cit., p. 318. Em tradução livre: “A dignidade humana constitui não só a garantia negativa de que a pessoa não será objeto de ofensas ou humilhações, mas engloba também a afirmação positiva do pleno desenvolvimento da personalidade de cada indivíduo. O pleno desenvolvimento da personalidade supõe, por sua vez, de um lado, o reconhecimento de uma total auto-disponibilidade, sem interferências ou impedimentos externos, das possibilidades de atuação própria de cada ser humano; de outro, a autodeterminação (Selbstbestimmung des Menschen) que surge da livre projeção histórica da razão humana, mais do que de uma pré-determinação natural".
}

${ }^{169}$ Idem, p. 318. No mesmo sentido, esclarece Luiz Fernando Calil de Freitas: "À similitude do direito constitucional alemão, analisado por Sarlet à guisa de examinar a proteção ao núcleo essencial viável de ser admitida no âmbito do direito nacional, o sistema constitucional brasileiro atualmente em vigência se funda no princípio da dignidade humana, princípio este que, conforme já afirmado no presente trabalho, se efetiva no sistema de direitos fundamentais constitucionalmente consagrados, sendo sólidas e amplas as correntes doutrinária e jurisprudencial que assim entendem. Nesse sentido, como igualmente já afirmado, a dignidade humana manifesta-se em cada direito fundamental, disso decorrendo que a afetação ao núcleo essencial do direito fundamental importaria ofensa direta à dignidade humana - muito embora núcleo essencial e dignidade humana não se possam confundir - porque afetado o núcleo essencial, desapareceria o direito fundamental em causa e, em decorrência disso, tal forma específica de manifestação da dignidade humana deixaria de gozar da proteção jusfundamental. De igual sorte, a exortação constitucional da prevalência dos direitos humanos contribui na construção do fundamento da vigência da proteção ao núcleo essencial na ordem jurídico-constitucional brasileira. Ora, os direitos fundamentais, em larga medida, são os direitos humanos protegidos pela ordem constitucional interna. As declarações internacionais acerca do tema postulam a adoção pelos Estados soberanos do reconhecimento, em suas ordens jurídicas, dos direitos humanos que declaram. Em igual sentido, os tratados internacionais versando sobre direitos humanos celebrados entre os Estados são compromissos multilaterais na busca da internacionalização, nas respectivas ordens jurídico-constitucionais, daqueles direitos como fundamentais. De tal lógica decorre que a norma que afirma a tais produz efeitos de proteção do respectivo núcleo essencial, de vez que sua derrogação importaria desproteção, em nível interno, do direito humano com idêntico conteúdo" (Direitos fundamentais: limites $e$ restrições, Porto Alegre, Livraria do Advogado, 2007, pp. 194 e 195). 
excesso do poder legislativo ${ }^{170}$, por isso se relaciona com o que os alemães denominam de proibição de excesso (Übermassverbot). Pelo princípio da proporcionalidade, o legislador deve compatibilizar as opções políticas com os princípios constitucionais."171

Para melhor compreensão deste insidioso debate, sobre a compatibilidade de utilização do princípio da proporcionalidade e a teoria dos núcleos essenciais dos direitos fundamentais, é preciso estabelecer, inicialmente, o que se entende por núcleo essencial de um direito fundamental e consignar a existência de duas teorias a respeito do assunto: a teoria absoluta e a teoria relativa.

O núcleo essencial dos direitos humanos "consiste no seu conteúdo mínimo, insuscetível de violação, sob pena de aniquilação do próprio direito" ${ }^{172}$. Existem, com relação ao "núcleo essencial dos direitos humanos", duas teorias distintas: uma teoria absoluta, pela qual se entende que cada direito fundamental se divide em duas partes, uma que constituiu um conteúdo mínimo, essencial, insuscetível de qualquer violação, e outra não essencial, que pode sofrer algum tipo de limitação, devidamente justificada ${ }^{173}$; e uma teoria relativa, que admite a restrição ao direito fundamental mediante um juízo de ponderação e justificação, para a proteção de outros direitos fundamentais, constituindo-se

\footnotetext{
${ }^{170}$ Interessante observação faz Gilmar Ferreira Mendes, demonstrando que, no direito alemão, a omissão legislativa (Ermessensunterschreitung; der Ermessensmangel) é equiparável ao excesso de poder legislativo, sendo igualmente vetado, já que "o poder discricionário de legislar contempla, igualmente, o dever de legislar" (Gilmar Ferreira Mendes, "O princípio da proporcionalidade...”, cit., p. 362). No mesmo sentido, Virgílio Afonso da Silva, "O proporcional e o razoável”, in: Haradja Leite Torrens e Mario Sawatani Guedes Alcoforado (coords.), A expansão do Direito: estudos de Direito Constitucional e Filosofia do Direito em homenagem a Willis Santiago Guerra Filho (por duas décadas de docência e pesquisas), Rio de Janeiro, Lumen Juris, 2004, p. 88: "Conquanto a regra da proporcionalidade ainda seja predominantemente entendida como instrumento de controle contra excesso dos poderes estatais, cada vez mais vem ganhando importância a discussão sobre a sua utilização para finalidade oposta, isto é, como instrumento contra a omissão ou contra a ação insuficiente dos poderes estatais".

${ }^{171}$ Irene Patrícia Nohara, op. cit., p. 61.

${ }^{172}$ Idem, ibidem.

${ }^{173}$ Cf. Luiz Fernando Calil de Freitas, op. cit., p 198: “Quanto à teoria absoluta, de modo completamente diverso, sua caracterização se faz a partir da consideração de que existe uma esfera permanente de direito fundamental que constitui seu núcleo ou essência, que independe das circunstâncias do caso concreto. (...) Cuida-se de uma interpretação material do conteúdo dos direitos fundamentais, a qual opera nitidamente com a distinção interna a cada direito fundamental em duas partes.

A primeira composta pelo seu núcleo essencial e outra composta por uma parte não essencial. Assim, o conteúdo essencial é apenas uma parte do direito fundamental que sempre estará protegida das intervenções desvantajosas; as hipóteses fáticas incluídas na parte considerada não essencial do direito fundamental apenas eventualmente aproveitarão da proteção respectiva, podendo, em contrário, sofrer restrições desde que justificáveis".
} 
o seu "núcleo essencial" justamente esse limite, a partir do qual se caracteriza o excesso de $\operatorname{poder}^{174}$.

A opção por uma ou outra teoria interfere na opção pela utilização ou não do princípio da proporcionalidade. Como bem pontuado por MORAES, o estudioso deve fazer uma escolha metodológica: “Ou ele aceita a 'teoria dos princípios', com os consectários do direito prima facie restringível, do suporte fático amplo, da teoria externa para a restrição de direitos, da aplicação da proporcionalidade conforme as condições fático-jurídicas do caso concreto e, por fim, a idéia de conteúdo essencial relativo; ou, em sentido contrário, deverá escolher correntes teóricas que aceitam noções como 'limites imanentes', 'limites internos', ‘direito definitivo' (não restringível após conformado), suporte fático restrito, teoria interna para o tema das restrições e, por fim, conteúdo essencial absoluto. Sendo que, aceitando a teoria interna, após todos os cortes ideológicos e valorativos realizados priori (no momento legislativo), estará impossibilitado de aplicar a proporcionalidade para qualquer necessária adaptação da norma à situação concreta. Isto porque, lembre-se, como para a teoria interna os direitos são irrestringíveis, uma vez (com)formados, constituem-se em 'direitos definitivos', impassíveis de redução por meio da ponderação ou da proporcionalidade" ${ }^{175}$.

A defesa intransigente da Constituição e o receio de flexibilização do sistema, levando a uma aniquilação dos direitos fundamentais não raro leva a que os autores defendam a teoria absoluta dos núcleos essenciais, admitindo, todavia, na prática, o controle por meio da proporcionalidade, que leva a uma ponderação entre direitos, que podem ser suprimidos completamente num caso concreto, em prol da integral realização de

\footnotetext{
${ }^{174}$ Idem, pp. 196 e 197: "A teoria relativa parte da premissa conforme a qual toda restrição a direitos fundamentais exige uma justificação, tenha ela autorização constitucional explícita ou implícita, no último caso desde que corresponda à necessidade de preservar outros direitos fundamentais ou outros bens constitucionalmente protegidos. Daí a razão porque Alexy afirme que o conteúdo essencial é o que resulta depois de uma ponderação com aqueles bens que justificam a restrição. Destarte, essa compreensão não opera com a idéia de existência de um elemento fixo, permanentemente identificável como núcleo essencial de um direito fundamental. Ao núcleo essencial do direito fundamental, nessa linha de considerações, chegase a partir de um juízo de ponderação com recurso ao princípio da proporcionalidade que se realiza no caso concreto, como forma de verificar se a medida restritiva é adequada à proteção do bem constitucional por ela pretendido garantir, se a intensidade da intervenção desvantajosa no direito fundamental em causa é inevitável, em razão da inexistência de alternativa menos desvantajosa e, por fim, se a lesão produzida com a afetação desvantajosa ao direito fundamental é proporcional à proteção conferida ao bem constitucionalmente protegido que se apresenta contraposto. Nesse contexto dogmático, o núcleo essencial está protegido quando, no caso concreto, a limitação ou restrição se acha justificada (...)".

${ }^{175}$ Maurício Zanoide de Moares, op. cit., p. 327.
} 
outro, mediante devida justificação, o que acaba fazendo com que incorram em uma contradição $^{176}$.

A teoria relativa é a que melhor se ajusta às necessidades práticas de ponderação entre os direitos fundamentais. A teoria relativa quanto ao núcleo essencial dos direitos fundamentais conferiu a base filosófica para o desenvolvimento dos critérios de adequação, necessidade e proporcionalidade em sentido estrito, que, como a seguir se demonstrará, proporcionaram uma pauta de justificação para a restrição de direitos humanos fundamentais, indispensável para a preservação do indivíduo em face do poder estatal.

\subsubsection{Adequação}

O critério da adequação (Geeignetheit), segundo o qual a medida restritiva precisa ser apta ou adequada a alcançar o fim almejado, é o primeiro a ser considerado na escala lógica do raciocínio utilizado para se verificar se uma medida atende ao princípio da proporcionalidade.

Indispensável, portanto, que, em primeiro lugar, exista um fim a ser buscado $^{177} \mathrm{e}$, então, que o fim ou o resultado pretendido esteja definido, para que se possa perquirir sobre a idoneidade do meio selecionado para atingi-lo.

O desvio de finalidade por parte do legislador não interfere nesse momento da análise. A escolha dos meios adequados à consecução dos fins parte do pressuposto de que os fins buscados estejam dentro do âmbito do exercício legítimo do poder, limitandose a verificar quais meios poderiam contribuir para alcançar aquele fim determinado. Como adverte PIMENTA OLIVEIRA: “Observa-se que se deve diferenciar a hipótese de

\footnotetext{
${ }^{176} \mathrm{O}$ alerta é feito por Maurício Zanoide de Moraes, op.cit., p. 405, ele próprio reconhecendo que em trabalhos anteriores à sua tese de livre-docência incorria no mesmo equívoco, "por apreço incondicional à defesa da Constituição". Com o estudo na obra em questão, repensando o assunto, chegou á conclusão de que "a melhor e maior defesa dos direitos fundamentais se dá pela perspectiva do conteúdo essencial relativo dos direitos fundamentais".

177 "El primer subprincipio del principio de proporcionalidad es el de adecuación o idoneidad. Lo primero que se exige de una medida es que tenga un fin. Lo segundo, que sea adecuada para el logro de ese fin. Es decir, que sea capaz de causar su objetivo. El subprincipio de adecuación tiene por finalidad controlar una cosa y otra" (Juan Cianciardo, op. cit., p. 62). Traduzido livremente: "O primeiro subprincípio do princípio da proporcionalidade é o da adequação ou idoneidade. A primeira coisa que se exige da uma medida é que tenha um fim. A segunda é que seja adequada para o atingimento desse fim, ou seja, que seja capaz de dar causa ao seu objetivo. O subprincípio da adequação tem por finalidade controlar as duas coisas”.
} 
desvio de finalidade da ocorrência de inadequação. Com efeito, se a medida visa finalidade contrária à consagrada na lei de habilitação (seja outra de natureza pública, ou meramente privada), em verdade, há vício no pressuposto teleológico da medida. Cogitar de vício de adequação pressupõe que a decisão não esteja eivada de desvio de poder. A inadequação, neste sentido, é um vício de ponderação na eleição de medidas possíveis, todas teleologicamente válidas, mas que no caso concreto não leva à consecução da finalidade perseguida pelo provimento administrativo" $" 178$.

Ainda de acordo com a máxima da adequação, o meio deve favorecer sensivelmente o resultado desejado. Assim, não precisa se estabelecer uma relação de esgotamento, ou seja, que o meio buscado esgote o fim buscado, realizando-o por completo.

Constata-se na doutrina a discussão sobre se a adequação dos meios deve ser analisada sempre ex ante ou se se admite um juízo ex post em relação ao momento da restrição ao direito fundamental. Como a verificação da adequação comporta um juízo lógico, isto é, realizado em tese, deve, como tal, ser prévio, ex ante ${ }^{179}$, não se admitindo a aceitação de meios que, num primeiro momento, se afiguravam inadequados, mas que, acidentalmente, ou concretamente, lograram alcançar o fim almejado. Tal ocorre na atividade legislativa, mas não se pode menosprezar a aplicação do princípio também no âmbito judicial, no momento da aplicação da lei, em casos em que a restrição já ocorreu em concreto, hipótese na qual a avaliação da adequação do meio apenas poderá ser avaliada ex post, isto é, se o meio que em tese não levaria à consecução do resultado, acabou atingindo-o na realidade concreta. $\mathrm{O}$ juiz não pode ignorar, de qualquer forma, a adequação dos meios à época da tomada de decisão pelo legislador, não desprezando, assim, a possibilidade de erro de prognose ${ }^{180}$.

Por fim, cumpre esclarecer que, a despeito do que a nomenclatura possa sugerir, não se questiona no âmbito da adequação que o meio seja o mais adequado,

\footnotetext{
${ }^{178}$ José Roberto Pimenta Oliveira, op. cit., p. 52.

179 "Este prognóstico deve mostrar-se justificado e razoável, em um juízo de valoração ex ante (e não ex post) da medida, em que basta comprovar a possibilidade abstrata do meio atingir o fim perseguido com a emanação do ato estatal. Assim, não se exige efetiva realização, mas se demanda que $a$ priori a medida seja suscetível de alcançar o fim perseguido. Se a medida for in totum inepta para a consecução da finalidade proposta, é considerada inválida, da mesma forma que, revelando-se a posteriori absolutamente inidônea o princípio exige a invalidação da mesma" (José Roberto Pimenta Oliveira, op. cit., p. 51).
}

${ }^{180}$ Suzana de Toledo Barros, op. cit., p. 80. 
bastando que seja suficiente para contribuir para o resultado ${ }^{181}$. O juízo não é, portanto, de escolha do melhor meio, mas de mera exclusão daqueles meios que não levarão ao fim visado. Excluída, portanto, qualquer consideração acerca da eficácia do meio ${ }^{182}$. Trata-se apenas de procedimento destinado a identificar uma relação de causalidade entre ambos.

Como é possível perceber, o uso do critério da adequação não é tão simples, e traz alguns questionamentos de difícil solução ${ }^{183}$, especialmente em sua aplicação prática.

\subsubsection{Necessidade}

Como dentre as medidas adequadas para a realização do fim perseguido, certamente poderão existir opções extremamente restritivas, faz-se necessário, para atender a um juízo de razoabilidade, ainda outro critério, qual seja o da necessidade (Notwendigkeit ou Erforderlichkeit). Segundo o juízo da necessidade, apenas o meio menos gravoso dentre os meios adequados pode ser aceito ${ }^{184}$.

O juízo da necessidade, portanto, segue-se à análise da adequação, tendo, ademais, um grau de importância maior na verificação da proporcionalidade. "Ressalte-se que, na prática, adequação e necessidade não têm o mesmo peso ou relevância no juízo de

${ }^{181}$ Conferir, a respeito, José Roberto Pimenta Oliveira, op. cit., p. 51.

${ }^{182}$ Suzana de Toledo Barros, op. cit., p. 78.

183 Juan Cianciardo, op. cit., p. 62: “Como ocurre con muchos conceptos aparentemente sencillos, detrás de la exigencia de adecuación se esconden problemas de cierta complejidad. Plantearemos los tres siguientes: a) en qué medida es importante determinar con precisión la finalidad que se procura alcanzar mediante el dictado de la ley; b) si la adecuación que se exige debe ser ex ante o a posteriori del dictado de la norma, y c) si el juicio de idoneidad tiene carácter técnico o se reduce a una evaluación de la mera posibilidad que tiene la norma cuestionada de alcanzar su objetivo". Tradução livre: "Como ocorre com muitos conceitos aparentemente simples, por trás da exigência de adequação se escondem problemas de certa complexidade. Citaremos os três seguintes: a) em que medida é importante determinar com precisão a finalidade que se procura alcançar mediante a disposição legal; b) se a adequação que se exige deve ser ex ante ou a posteriori da disposição legal, e c) se o juízo de idoneidade tem um caráter técnico ou se reduz a uma avaliação de mera possibilidade apresentada pela norma de alcançar o seu objetivo".

184 “El juicio de necesidad es, en lo que a la aplicación se refiere, el más controvertido de los tres que forman la máxima de proporcionalidad. Ha sido también llamado 'juicio de indispensabilidad'. Mediante él se examina si la medida adoptada por el legislador es la menos restringente de las normas iusfundamentales de entre las igualmente eficaces. Se exige, por tanto, la adopción de la 'alternativa menos gravosa o restrictiva de los derechos" (Idem, p.79). Traduzido livremente: "O juízo de necessidade é o mais controvertido dos três que formam a máxima da proporcionalidade. Tem sido chamado também de 'juízo de indispensabilidade'. Com ele, examina-se se a medida adotada pelo legislador é a menos restritiva das normas de direitos fundamentais dentre as igualmente eficazes. Exige-se, portanto, a adoção da 'alternativas menos gravosa ou restritiva de direitos"". 
ponderação. Assim, apenas o que é adequado pode ser necessário. O que é necessário não tem como ser inadequado. Pieroth e Schlink ressaltam que a prova da necessidade tem maior relevância do que o teste da adequação. Positivo o teste da necessidade, não há de ser negativo o teste da adequação. Por outro lado, se o teste quanto à necessidade revelarse negativo, o resultado positivo do teste de adequação não mais poderá afetar o resultado definitivo ou final" ${ }^{\text {185 }}$. O meio só é necessário, se não houver outro meio eficaz, menos restritivo aos direitos fundamentais.

Pode-se, ainda, afirmar que o critério da necessidade advém de uma imposição constitucional, de proteção máxima dos direitos fundamentais, e de restrição da atuação estatal apenas ao estritamente necessário para a proteção de outros direitos fundamentais. Na sistemática alemã, a necessidade é a indagação central dentro do princípio da proporcionalidade, porque está diretamente relacionada com a noção de proibição do excesso e de vedação à restrição que ultrapasse os limites de proteção do núcleo essencial dos direitos humanos ${ }^{186}$.

A necessidade da restrição a um direito fundamental deve, ademais, ser tanto qualitativa quanto quantitativa. Uma restrição que se prolonga no tempo além do estritamente necessário para a consecução do fim almejado perde a sua legitimação, tornando-se desproporcional. Ressalta, neste sentido, SUZANA DE TOLEDO BARROS que, "de fato, uma medida legislativa restritiva considerada apta quanto ao modo de restrição conducente ao resultado a ser obtido pode se revelar totalmente inadequada quando se questiona, por exemplo, a sua duração no tempo" ${ }^{\text {187 }}$.

Quando se refere ao direito penal e ao direito processual penal, âmbito da presente pesquisa, a necessidade da medida há que ser vista com ainda maior rigor, dado que o direito fundamental em jogo é a liberdade, um dos que dispõem de maior proteção em todos os ordenamentos jurídicos. "No direito penal, o princípio da necessidade fundase na exigência constitucional de que o interesse a ser protegido pela norma apresente relevância suficiente para poder justificar, em contrapartida, uma delimitação da esfera de liberdade" ${ }^{188}$.

\footnotetext{
${ }^{185}$ Gilmar Ferreira Mendes, “O princípio da proporcionalidade...”, cit., p. 365.

186 “A necessidade ou a exigibilidade do meio utilizado pelo legislador está diretamente relacionada com a impossibilidade de restrição do conteúdo essencial (Wesengehalt) de direito fundamental, positivada na segunda alínea do art. 19 da Lei Fundamental” (Irene Patrícia Nohara, op. cit., p. 61).

${ }^{187}$ Suzana de Toledo Barros, op. cit., p. 83.

${ }^{188}$ Mariângela Magalhães, op. cit., p. 83.
} 


\subsubsection{Proporcionalidade em sentido estrito}

Prosseguindo nesta lógica do razoável, verifica-se que apenas os critérios da adequação e da necessidade não se mostram suficientes ao tipo de proteção que se pretende aos direitos fundamentais por meio do princípio da proporcionalidade.

Existem ocasiões em que o fim é definido, o meio é considerado apto a alcançá-lo e, dentre todos os possíveis, o menos restritivo, mas, ainda assim, verifica-se que a atuação estatal não se legitima, porque a restrição se afigura desproporcional ao fim buscado.

A proporcionalidade em sentido estrito pressupõe uma ponderação, uma comparação entre a magnitude do meio empregado e a relevância e o benefício do fim almejado $^{189}$. Por vezes, existe um único meio, adequado e necessário para atingir um determinado fim, mas este é tão gravoso em relação ao benefício, que deve ser repudiado, em prol da sistemática de proteção aos direitos humanos. "Trata-se de comparar objetivo e meio, e de ponderá-los em sua respectiva importância"190.

Como bem observado por PIMENTA OLIVEIRA, quanto mais contundente for a atuação estatal na esfera de direitos individuais, maior deverá ser a relevância do interesse a ser protegido pelo fim buscado: “Quanto mais sensível a intervenção na esfera jurídica do indivíduo, mais relevante deve se caracterizar o interesse da coletividade que se busca proteger, o que somente é apurável no exame das circunstâncias concretas. Demais disso, a valoração comparativa é ditada em função do 'peso e urgência do interesse geral' em questão, como também deve considerar os interesses individuais objeto de proteção por parte da ordem jurídica" ${ }^{\prime 191}$.

Um exemplo bastante recorrente no direito brasileiro envolve a interceptação telefônica. Dentro de uma investigação criminal, pode ocorrer que a única forma de fazer prova do cometimento de uma prática delituosa seja por meio de uma

\footnotetext{
189 “A exigência de ponderação, de balanceamento, enfim, de equilíbrio pressupõe e modaliza-se consoante a utilização e determinados critérios objetivos. A valoração comparativa deve guiar-se: (i) pela incisividade da intervenção na esfera jurídica do indivíduo, (ii) pelo peso e urgência do interesse geral, e (iii) pelo interesse individual objeto de proteção por parte da ordem jurídica” (José Roberto Pimenta Oliveira, op.cit., p. 56).

${ }^{190}$ Idem, p. 55.

${ }^{191}$ Idem, p. 56.
} 
interceptação telefônica. Tem-se, portanto, neste exemplo, um meio adequado, porque possibilita o atingimento do fim, e necessário, pois é o único meio possível para se chegar ao resultado, portanto, o menos gravoso. Mas se o crime sob investigação for apenado apenas com detenção ${ }^{192}$, por exemplo, em que o início do cumprimento da pena ocorre no regime semi-aberto ou aberto, percebe-se que uma ingerência de tal monta na intimidade da pessoa configuraria uma medida desproporcional ao fim alcançado.

Esse é o significado original do critério da proporcionalidade em sentido estrito, tal como originado na Alemanha. Todavia, uma análise mais aprofundada demonstrará que um certo juízo valorativo sobre a legitimidade do fim escolhido pelo legislador, ausente nesta conformação tripartite, não escapou à jurisprudência e à doutrina alemãs, sendo que o princípio da proporcionalidade contemplou, na prática, uma outra análise, de conformação dos fins eleitos com os valores constitucionalmente assegurados, assemelhando-se a uma espécie de controle de constitucionalidade ${ }^{193}$.

De acordo com SUZANA DE TOLEDO BARROS, o princípio da proporcionalidade vem sendo largamente utilizado pela Corte Constitucional alemã como uma fórmula adequada ao controle de constitucionalidade das leis, porque "contém o substrato teórico necessário para fundamentar a decisão político-jurídica dos juízes e tribunais, quando o arbítrio legislativo é evidente, mas nem sempre comprovado com facilidade pelo confronto da lei à Constituição"194.

Temeu-se, é verdade, que o Judiciário passasse a questionar a conveniência e a oportunidade de que dispõem o Legislativo para a criação das leis, crítica esta que não

${ }^{192}$ A própria lei de interceptações telefônicas (Lei $\mathrm{n}^{\circ}$ 9.296, de 24 de julho de 1996), em seu artigo $2^{\mathrm{o}}$, segue o princípio da proporcionalidade para guiar a aplicação da medida:

"Art. $2^{\circ}$ Não será admitida a interceptação de comunicações telefônicas quando ocorrer qualquer das seguintes hipóteses:

I - quando não houver indícios razoáveis da autoria ou participação em infração penal;

II - a prova puder ser feita por outros meios disponíveis;

III - o fato investigado constituir infração penal punida, no máximo, com pena de detenção."

Pode-se deduzir deste dispositivo legal a consagração dos três critérios da proporcionalidade: o da necessidade, englobando a adequação, e o da proporcionalidade, indicando que a medida apenas poderá ser usada quando absolutamente necessária e de forma proporcional ao fim buscado. Assim, fora dos casos expressamente consignados, não se exclui a aplicação do mesmo princípio para todos os casos que envolvem interceptação telefônica.

${ }^{193}$ Cf. Gilmar Ferreira Mendes, "O princípio da proporcionalidade...”, cit., p. 365: "Um juízo definitivo sobre a proporcionalidade da medida há de resultar da rigorosa ponderação e do possível equilíbrio entre o significado da intervenção para o atingido e os objetivos perseguidos pelo legislador (proporcionalidade em sentido estrito). É possível que a própria ordem constitucional forneça um indicador sobre os critérios de avaliação ou de ponderação que devem ser adotados. Pierpth e Schlink advertem, porém, que, nem sempre, a doutrina e a jurisprudência se contentam com essas indicações fornecidas pela Lei Fundamental, incorrendo no risco ou na tentação de substituir a decisão legislativa pela avaliação subjetiva do juiz".

${ }^{194}$ Suzana de Toledo Barros, op. cit., pp. 49 e 50. 
resiste a uma visão sob a perspectiva do checks and balances, ou seja, de controle entre os Poderes, lembrando que é função dos juízes, sem adentrar na conveniência política da lei, ou no mérito das razões que conduziram à criação de um lei, a verificação de sua conformidade com as normas constitucionais, para a preservação dos valores fundantes do Estado Democrático de Direito e de preservação máxima dos direitos fundamentais, ainda que o confronto não se dê com relação a uma norma expressa, mas à toda a sistemática constitucional de proteção aos direitos fundamentais, sob pena de retorno aos males do positivismo, já posto à prova, com derrota reconhecida.

Tal percepção aproxima ainda mais os dois conceitos, de razoabilidade e de proporcionalidade, como adiante se verá.

\subsubsection{Inglaterra}

O desenvolvimento do princípio da razoabilidade foi pequeno na Inglaterra, que vê na idéia do devido processo legal o mecanismo de restrição ao poder estatal por excelência. Mas a criação da cláusula do devido processo legal neste país possibilitou que mais tarde se originasse o princípio da razoabilidade a partir de uma noção material do devido processo legal.

A doutrina identifica as raízes do devido processo legal no artigo 39 da Magna Carta de 1.215. "Na Inglaterra, não se falava ainda em devido processo legal, mas em legem terrae (ainda em latim), ou, posteriormente, law of land. A expressão continha um sentido originário, acolhedor de uma série de garantias processuais. Costuma-se ressaltar que as idéias contidas na Magna Carta foram transplantadas da metrópole para as Declarações de Direitos da colônia.

Impende, contudo, advertir que há muita mistificação em torno da importância da Magna Carta como real instrumento de limitação do exercício arbitrário do poder estatal. Apesar de sua adoção geral como modelo de defesa dos súditos, dos administrados e dos jurisdicionados contra arbitrariedades da monarquia, historicamente, ela não implicou na efetivação dos direitos humanos, nem de substancial parcela dos direitos dos súditos diante da monarquia.

A Magna Carta não pode ser classificada como Declaração de Direitos. Ela foi, na realidade, uma carta de privilégios feudais firmada entre o rei João sem Terra (John 
the Lackland) e os barões, portanto, entre o monarca e parcela da nobreza e a maior parte de suas previsões sequer foi cumprida" ${ }^{195}$.

Além disso, o writ of reasonableness, que decorre do próprio sistema da commom law, em que cabe ao juiz, a partir dos precedentes judiciais construir a decisão razoável para o caso, teve influência sobre a forma de aplicação do princípio nos Estados Unidos, como se verá no próximo tópico.

\subsubsection{Estados Unidos}

Nos Estados Unidos, sob a herança inglesa da noção do devido processo legal, desenvolveu-se o princípio da razoabilidade ${ }^{196}$.

Contemplado expressamente na $5^{\mathrm{a}}$ Emenda e na $14^{\mathrm{a}}$ Emenda, o devido processo legal passou de uma garantia de matiz meramente processual para uma garantia também de contornos materiais, utilizada como mecanismo de resguardo do cidadão a legislações irrazoáveis por parte do legislador ${ }^{197}$.

Todavia, essa passagem não se mostrou muito fácil, havendo por certo tempo uma forte resistência por parte da Suprema Corte em adentrar na "justiça das leis". Em 1872 foi julgado um caso envolvendo uma empresa, em busca do reconhecimento de seu monopólio, Slaugther Houses Cases, em que a extensão do conteúdo da $14^{\mathrm{a}}$ Emenda foi mantida num âmbito estritamente processual, mas após longa polêmica e a existência de votos divergentes. Em 1876, no julgamento do caso Missouri Pacific Ra. v. Humes, no Município de Illinois, a Suprema Corte chegou a declarar que o remédio contra as más leis deveria ser buscado nas urnas, e não junto aos juízes ${ }^{198}$.

\footnotetext{
${ }^{195}$ Irene Patrícia Nohara, op.cit., p. 51.

196 "El punto de partida del desarrollo que concluiría en los Estados Unidos con la formulación de la idea de razonabilidad lo constituye la garantía del debido proceso legal, institución que hunde sus raíces en el derecho de Inglaterra. Los antecedentes de la expresión due process of law (debido proceso legal) se encuentran en la Carta Magna, impuesta por los nobles ingleses al rey Juan Sin Tierra." (Juan Cianciardo, op. cit., p. 32). Tradução livre: "O ponto de partida do desenvolvimento que propiciaria a formulação nos Estados Unidos da idéia de razoabilidade foi a garantia do devido processo legal, instituição que deita suas raízes no direito inglês. Os antecedentes da expressão due process of law (devido processo legal) se encontram na Carta Magna, imposta pelos nobres ingleses ao rei João Sem Terra".
}

${ }^{197}$ De acordo com Juan Cianciardo, op. cit., p. 45, o devido processo legal foi entendido inicialmente como uma garantia de caráter exclusivamente processual (devido processo adjetivo) e que, como o tempo, foi interpretado como uma forma de resguardo constitucional contra a legislação irrazoável (devido processo substantivo).

${ }^{198}$ Ver, a respeito, Suzana de Toledo Barros, op. cit., p. 64. 
Ocorre que o devido processo legal, utilizado desde o início como um instrumento de controle judicial, diante da desconfiança dos colonos em relação às atitudes do Parlamento inglês, especialmente no tocante a restrições ao direito de propriedade ${ }^{199}$, adquiriu desde logo uma característica bastante peculiar, de instrumento de tutela de alguns direitos fundamentais, para garantia do livre desenvolvimento econômico em ascensão, o que abriu um caminho importante para o posterior desenvolvimento do princípio da razoabilidade, a partir da passagem do devido processo legal de instrumento meramente processual para um âmbito material.

De fato, com a recepção do sistema jurídico inglês da common law pelos Estados Unidos, propiciou-se o desenvolvimento rápido do princípio da razoabilidade. Baseado em construções jurisprudenciais e precedentes concretos, o sistema da common law permitiu a criação de uma sistemática de grande aplicabilidade prática em torno da idéia de razoabilidade, sem que fosse necessário fixar um conceito estanque. "Inspirado na common law, que garantiu aos juízes americanos maior desenvolvimento do direito por meio da prática jurisprudencial, e sob a influência do jusnaturalismo, que tem o Direito como ideal de justiça e limite à atuação do Estado intervencionista, o modelo americano de controle vem permitindo refrear o arbítrio do legislador e do administrador, pela sindicância da razoabilidade dos atos governamentais" ${ }^{, 200}$.

Mas foi após a crise de 1929 e a implementação das práticas intervencionistas do New Deal por Franklin Roosevelt, abandonando-se os ideais liberais até então vigentes, que a necessidade de restauração de um controle de proteção aos direitos individuais se fez patente, momento em que o princípio da razoabilidade teve um importante papel.

Assim, nos Estados Unidos, a exemplo do que aconteceu na Alemanha, houve um maior desenvolvimento do princípio após uma fase intervencionista do Estado, o que reafirma a vocação de proteção individual ${ }^{201}$ de ambos os princípios.

\footnotetext{
${ }^{199}$ Suzana de Toledo Barros, op. cit., p. 60, refere que os colonos tiveram seus direitos postergados inúmeras vezes pela prepotência das assembléias e dos governadores nomeados pela Coroa, sobretudo em relação aos direitos de propriedade.

${ }^{200}$ Idem, pp. 62 e 63.

201 De acordo com Juan Cianciardo, op. cit., p. 35, "pode-se afirmar que, desde o final do século XIX, o devido processo substantivo consistiu basicamente em uma garantia de razoabilidade das decisões de qualquer dos órgãos do Estado: é irrazoável toda decisão que afeta os direitos fundamentais protegidos pela Constituição", traduzido livremente.
} 
Conforme esclarece IRENE P. NOHARA, a jurisprudência dos Estados Unidos evoluiu bastante, ao ponto de se estabelecer alguns critérios para a verificação da razoabilidade, no âmbito da construção do devido processo legal, em sua vertente substantiva: o rule of expediency, o balance of convenience, o rule of reasonableness, e o rule of certainty ${ }^{202}$.

O desenvolvimento do substantive due process of law nos Estados Unidos, com a fixação destes critérios, propiciou uma convergência entre os princípios da razoabilidade e da proporcionalidade, tornando-os conceitualmente ainda mais próximos.

No rule of expediency, por exemplo, é possível ver a mesma regra da necessidade do direito alemão, exigindo-se a demonstração da efetiva necessidade da restrição. O balance of convenience, por sua vez, pode ser identificado como contendo um juízo de ponderação bastante próximo do juízo de proporcionalidade em sentido estrito ao mesmo tempo em que admite uma perquirição de adequação.

A construção americana inclui, ainda, a especificação de outros dois critérios, o rule of certainty, cuja construção muito se aproxima do princípio da legalidade, já que exige, para a restrição de direitos fundamentais, uma lei prévia, certa e estrita, e o rule of reasonableness, que é uma espécie de juízo de "razoabilidade em sentido estrito", e que contém a parcela mais indefinida do princípio, que funciona como uma "válvula de escape" para algumas situações em que, eventualmente, sejam atendidos todos os demais critérios, mas a restrição ainda se afigure arbitrária, ilegítima do ponto de vista de seus fins.

$\mathrm{O}$ rule of reasonableness, por fim, tem os mesmos contornos do princípio da razoabilidade quando do início de sua aplicação na Inglaterra, na órbita do sistema da commom law, o que indica que, nos Estados Unidos, houve uma superação da limitação do sistema da common law e se ampliou bastante o alcance conceitual do princípio, o que fez com que superasse os contornos da proporcionalidade, guardando com este uma relação de continência, como adiante se verá.

\subsubsection{Portugal}

Em Portugal, a mesma idéia de proteção do indivíduo em face do excesso de poder estatal surgiu após a experiência da ditadura salazarista, despertando o país para a

\footnotetext{
${ }^{202}$ Cf. Irene Patrícia Nohara, op. cit., p. 58.
} 
preocupação com a democracia e a preservação das conquistas em matéria de direitos fundamentais $^{203}$.

Para evitar eventual recaída no futuro, após a adoção de uma concepção de democracia econômica, social e cultural, como fundamento do Estado, construiu-se doutrinariamente em Portugal, especialmente por força das revisões constitucionais de 1982 e 1989, o princípio da proibição do retrocesso social, ou proibição de contrarevolução social ou, ainda, proibição da evolução reacionária ${ }^{204}$.

Tal princípio encontra sua base no artigo 18 da Constituição Portuguesa, segundo o qual "a lei só poderá restringir direitos, liberdades e garantias nos casos expressamente previstos na Constituição, devendo as restrições limitar-se ao necessário para salvaguardar outros direitos ou interesses constitucionalmente protegidos”. Ainda, de acordo com este dispositivo, as leis restritivas têm de se revestir de caráter geral e abstrato e não podem ter efeito retroativo nem diminuir a extensão e o alcance do conteúdo essencial dos preceitos constitucionais.

Veda-se, com o princípio da proibição do retrocesso social que, uma vez alcançado um determinado grau de afirmação em matéria de direitos fundamentais, venha atuação legislativa tendente a retroceder neste avanço, restringindo direitos fundamentais além de um determinado limite admissível, que configura o já mencionado núcleo essencial destes direitos ${ }^{205}$.

O que se veda não é um retrocesso social de fato, decorrente de conjunturas factuais desfavoráveis, que nenhum país está a salvo de enfrentar, mas a sua restrição jurídica, seja por atuação restritiva do legislador, seja por atuação do Judiciário, na forma da aplicação dos direitos fundamentais até então reconhecidos.

Construiu-se em Portugal, portanto, a partir desse substrato conceitual, um sistema de controle de constitucionalidade baseado na violação do núcleo essencial de um direito fundamental, impingindo-se a sanção da inconstitucionalidade a toda norma que venha a violar este núcleo, excedendo-se no âmbito admissível de restrição. Trata-se, portanto, de forma de proibição do excesso, muito semelhante à idéia de proporcionalidade desenvolvida nos Estados Unidos e na Alemanha.

\footnotetext{
${ }^{203}$ Cf. Irene Patrícia Nohara, op. cit., p. 70.

${ }^{204}$ Cf. J. J. Gomes Canotilho, op. cit., p. 336.

${ }^{205}$ Idem, p. 337.
} 


\title{
4.1.5. Brasil
}

No direito brasileiro, não há previsão expressa seja do princípio da proporcionalidade, seja do princípio da razoabilidade ${ }^{206}$, como em outros países ${ }^{207}$, embora já fossem reconhecidos amplamente no país, especialmente no âmbito do direito administrativo.

O reconhecimento do princípio da proporcionalidade chegou a ser cogitado e até mesmo projetado, mas foi refutada a sua inclusão de forma expressa no texto constitucional $^{208}$. Todavia, como ocorre com qualquer princípio, não era necessário ter sido expresso ou deduzido em regras para existir, podendo decorrer da própria ordem constitucional, ainda que implicitamente.

De fato, as próprias circunstâncias históricas conduziram ao seu reconhecimento inequívoco pela Constituição de 1988. Após longa ditadura, premente se fez a previsão de mecanismos eficazes de proteção individual contra o excesso de poder pelo Estado, e o princípio da proporcionalidade, embora não tenha sido positivado, indubitavelmente foi acolhido de forma indireta, pois está refletido em toda a sistemática constitucional dos direitos fundamentais.

Há autores que o identificam com o princípio da igualdade ${ }^{209}$, especialmente levando em consideração o conceito de igualdade material, segundo o qual

\begin{abstract}
${ }^{206}$ A diferença entre as duas noções será abordada no item 4.2. infra. Para o momento, será tratada a abordagem dada ao princípio da proporcionalidade e ao princípio da razoabilidade forma conjunta e sem distinção, já que, no Brasil, tendo em vista que as duas concepções, por serem muito próximas e guardarem até mesmo uma relação de fungibilidade entre si, são muitas vezes tratadas como sinônimos. Ver, a respeito, por ora, consideração feita por Virgílio Afonso da Silva, op. cit., p. 89, de que há uma tendência em se confundirem ambos os conceitos, tanto na jurisprudência do Supremo Tribunal Federal quanto na doutrina, apontando muitos autores que admitem a identificação entre os dois conceitos, embora o autor faça críticas a este fenômeno, buscando distanciar as duas idéias.
\end{abstract}

${ }^{207}$ Como afirmado anteriormente, em Portugal existe previsão expressa do princípio, deduzido claramente da redação do artigo $18,2$.

208 “A razoabilidade pode ser considerada um princípio ostesivamente retirado do Projeto da Constituição pelo Constituinte, mas irremissivelmente acolhido pela sua obra positivada, ao lume da axiologia, sistematicidade e teleologia das normas insculpidas na Constituição promulgada em 5.10.1988. Eis um fato sem precedentes no direito constitucional brasileiro: um princípio que teve afirmada sua positividade aparentemente ao alvedrio da vontade do Constituinte, mas perfeitamente compatível com a vontade da Constituição". Cf, a respeito, José Roberto Pimenta Oliveira, op. cit., p. 201.

209 “Sua noção se extrai de outros princípios que lhe são afins, como o princípio da igualdade, sobretudo com a observância da igualdade-proporcionalidade, característica do Estado Contemporâneo" (Sylvia Marlene de Castro Figueiredo, A interpretação constitucional e o princípio da proporcionalidade, São Paulo, RCS Editora, 2005, p. 209). 
uma mesma regra ou direito deve ser aplicado na proporção das desigualdades apresentadas em cada caso concreto. De acordo com lição de ARAÚJO CINTRA, GRINOVER e DINAMARCO, passou-se de um conceito de igualdade formal e negativo, segundo o qual a lei não pode estabelecer qualquer diferença entre dois indivíduos, para um conceito material e positivo de igualdade proporcional, "que impõe tratamento desigual aos desiguais, justamente para que, supridas as diferenças se atinja a igualdade substancial" 210 .

Tal identificação com o princípio da igualdade traz importantes reflexos para o tema da garantia da razoável duração do processo. Processos "iguais" do ponto de vista do tempo necessário para a busca da verdade e proteção dos direitos fundamentais merecem tempo de duração "igual", independentemente de fatores irrelevantes para a fixação do prazo, tais como clamor social, gravidade do crime, etc. "Resumidamente, pode-se dizer: a razoabilidade exige que somente haja tratamento discriminatório se houver uma justificação razoável - um 'bom motivo' - para tanto, e a proporcionalidade determina que o discrimen apenas se dará na medida da realização do direito de outrem",211.

Também há autores, nesta mesma linha de pensamento, que, conquanto não admitam a existência de um princípio da proporcionalidade ou da razoabilidade, o identificam como um critério ou pauta de interpretação inerente ao princípio da eqüidade. $^{212}$

A eqüidade é "fruto de condições especiais de cultura, noção de justiça generalizada na coletividade (jus naturale, aequum, bonum) idéia comum do bem, predominante no seio de um povo em dado momento da vida social; a eqüidade abrolhou de princípios gerais preexistentes e superiores à lei, da fonte primária do Direito. É um sentimento subjetivo e progressivo, porém não-individual, nem arbitrário; representa o

\footnotetext{
${ }^{210}$ Antônio Carlos de Araújo Cintra, Ada Pellegrini Grinover e Cândido Rangel Dinamarco, Teoria Geral do Processo, $17^{\text {a }}$ ed., São Paulo, Malheiros, 2001, p. 54.

${ }^{211}$ Valeschka e Silva Braga, Princípios da proporcionalidade e razoabilidade, Curitiba, Juruá, 2004, p. 133.

${ }^{212}$ Eros Roberto Grau, "Eqüidade, razoabilidade, proporcionalidade e princípio da moralidade", Revista do Instituto de Hermenêutica Jurídica vol. 1, n. 3, Porto Alegre, 2005, p. 17. De acordo com o autor, "Nossa doutrina, no entanto, equivocadamente, toma-o como um princípio superior, pretendendo aplicá-lo a todo e qualquer caso concreto, o que conferiria ao Poder Judiciário a faculdade de 'corrigir' o legislador, invadindo a competência deste. Nada há, porém, de novo - repito - na proporcionalidade e na razoabilidade, postulados que, desde há muito e independentemente da formulação dessas duas noções, vem o Poder Judiciário exercitando na interpretação/aplicação do direito. Antes os denominava simplesmente eqüidade".
} 
sentir do maior número, não o do homem que alega ou decide"213. Guarda, portanto, relação direta com a idéia de razoabilidade e de proporcionalidade, ou seja, de busca pela justiça no caso concreto.

Assim, o princípio da proporcionalidade pode ser apontado como uma forma de controle de natureza eqüitativa que, de acordo com CANOTILHO, "contribui para a integração do 'momento de justiça' no palco da conflituidade social"214.

BANDEIRA DE MELLO, a seu turno, afirma que o princípio da razoabilidade encontra fundamento nos mesmos preceitos que arrimam constitucionalmente o princípio da legalidade, já que "uma providência administrativa desarrazoada, incapaz de passar com sucesso pelo crivo da razoabilidade, não pode estar conforme à finalidade da lei" ${ }^{215}$.

Não escapou à percuciente pesquisa de REALE JÚNIOR, que a previsão, no próprio Preâmbulo da Constituição da República de 1988, dos valores de liberdade e justiça, conduz ao reconhecimento do princípio da razoabilidade, como aquilo que se mostra justo, no caso concreto: "Pelo valor 'justiça', tal como constitucionalmente tutelado, deve este ser entendido como justiça material, que não se limita à garantia do exercício da jurisdição pelo Poder Judiciário e à garantia de que nenhuma lesão ou ameaça a direito será excluída da apreciação daquele Poder. Diversamente, a realização da justiça, como valor supremo a ser perseguido, importa na concretização do justo, do razoável e proporcional, estendendo-se a justiça material desde a elaboração legislativa até a aplicação efetiva das normas" 216 .

A Emenda Constitucional $n^{o} 45$, portanto, ao contemplar a existência de uma garantia constitucional à razoável duração do processo, nenhuma novidade trouxe, embora possa ser apontada como um significativo avanço, pois significou um prestígio ao princípio da razoabilidade, já presente no ordenamento, ao mesmo tempo em que promoveu um reconhecimento maior por parte da jurisprudência e aqueceu o debate na doutrina.

\footnotetext{
${ }^{213}$ Carlos Maximiliano, Hermenêutica e aplicação do direito, $6^{\text {a }}$ ed., São Paulo, Livraria Freitas Bastos, 1957, p.218.

${ }^{214}$ Cf. J. J. Gomes Canotilho, op. cit., p. 269.

${ }^{215}$ Celso Antônio Bandeira de Mello, Curso de Direito Administrativo, $22^{\mathrm{a}}$ ed., São Paulo, Malheiros, 2007, p. 106.

${ }_{216}$ Miguel Reale Júnior, Instituições de direito penal, vol. 1, Parte Geral, Rio de Janeiro, Forense, 2002, pp. 31 e 32 .
} 
Uma distinção aqui precisa ser feita. Não foi o princípio da razoabilidade que foi contemplado expressamente na Constituição com a Emenda $n^{0} 45$, como se tem afirmado na doutrina, mas uma regra, voltada apenas à questão da duração do processo e que, por sua vez, contém a noção de razoabilidade. O princípio da razoabilidade permanece ainda implícito dentro do ordenamento constitucional. Tal constatação, por óbvio, não deve trazer qualquer perplexidade e não impedirá o reconhecimento do princípio nem, tampouco, o seu acolhimento e desenvolvimento.

A noção da razoável duração do processo deve ser tratada como regra (de garantia), decorrente ou dependente de um princípio, aplicável de maneira geral, que é o princípio da razoabilidade. Conforme bem salientado por DWORKIN, é comum a utilização do termo razoabilidade em determinadas regras, sem que isso as transforme em princípios, mas apenas evidenciando a sua relação de dependência com alguns princípios: “Palavras como 'razoável', 'negligente', ‘injusto' e 'significativo' desempenham freqüentemente essa função. Quando uma regra inclui um desses termos, isso faz com que sua aplicação dependa, até certo ponto, de princípios e políticas que extrapolam a [própria] regra. A utilização desses termos faz com que essa regra se assemelhe mais a um princípio. Mas não chega a transformar a regra em princípio, pois até mesmo o menos restritivo desses termos restringe o tipo de princípios e políticas dos quais pode depender a regra"217.

É inegável, nestes termos, a presença do princípio da razoabilidade no ordenamento jurídico por meio de inúmeras regras, presentes em diversos dispositivos constitucionais, como é o caso do direito de resposta proporcional à ofensa ${ }^{218}$, a garantia de justa (leia-se razoável ou proporcional) indenização em caso de desapropriação ${ }^{219}$, o direito a um salário mínimo razoável ou proporcional ao atendimento das despesas necessárias às necessidade vitais básicas ${ }^{220}$, o direito a um piso salarial proporcional à

${ }^{217}$ Ronald Dworkin, Levando os direitos a sério, Trad. Nelson Boeira, São Paulo, Martins Fontes, 2002, p. 36.

${ }^{218}$ Cf. Artigo $5^{\circ}$, inciso V, segundo o qual "é assegurado o direito de resposta, proporcional ao agravo, além da indenização por dano material, moral ou à imagem".

${ }^{219}$ Cf. Artigo 5’, inciso XXIV, segundo o qual "a lei estabelecerá o procedimento para desapropriação por necessidade ou utilidade pública, ou por interesse social, mediante justa e prévia indenização em dinheiro, ressalvados os casos previstos nesta Constituição".

${ }^{220}$ Cf. Artigo $7^{\circ}$, inciso IV, segundo o qual é direito do trabalhador um "salário mínimo, fixado em lei, nacionalmente unificado, capaz de atender a suas necessidades vitais básicas e às de sua família com moradia, alimentação, educação, saúde, lazer, vestuário, higiene, transporte e previdência social, com reajustes periódicos que lhe preservem o poder aquisitivo, sendo vedada sua vinculação para qualquer fim". 
extensão e à complexidade do trabalho ${ }^{221}$, direito à percepção de remuneração proporcional ao tempo de serviço por parte do servidor posto em disponibilidade ${ }^{222}$, representação de deputados em número proporcional à população de cada Estado ${ }^{223}$, proibição do confísco, etc.

Ainda nos termos desenvolvidos por DWORKIN, o princípio sempre atende a uma exigência de justiça ou eqüidade, ou alguma outra dimensão da moralidade ${ }^{224}$, excluindo-se, portanto, a redução simplista da concepção positivista de retirar todo e qualquer elemento moral da teoria do Direito.

O reconhecimento da razoabilidade enquanto princípio é, portanto, inevitável, ao pensá-lo enquanto valor de caráter geral e abstrato, que permeia todo o ordenamento jurídico, alcançando todos os ramos do Direito, e completamente interligado a outros princípios, como o da eqüidade.

$\mathrm{Na}$ doutrina, os princípios a razoabilidade e da proporcionalidade encontraram reconhecimento imediato, e o debate acadêmico em torno deles tem aumento significativamente, com o afluxo de estudos provenientes da Alemanha e de Portugal, segundo relevante observação de IRENE PATRÍCIA NOHARA: "Esses institutos [princípio da razoabilidade e da proporcionalidade] estão sendo progressivamente utilizados na doutrina e na jurisprudência pátrias por inúmeros veículos: pela formulação substantiva do devido processo legal dos Estados Unidos, que também é colaboração de processualistas mais atualizados; pelos juristas que vão aprofundar seus estudos na Alemanha, ou em Portugal, e tomam contato com a proporcionalidade, com a proibição de excesso ou com uma hermenêutica constitucional sofisticada; e, de forma mais difusa, mas não menos importante, pela percepção bastante propagada na Filosofia do Direito, de que a retórica e a razão prática devem ser resgatadas para oferecer subsídios na formulação de uma hermenêutica sensível para a justiça do caso concreto" 225 .

\footnotetext{
${ }^{221} \mathrm{Cf}$. Artigo $7^{\circ}$, inciso V, segundo o qual é direito do trabalhador um "piso salarial proporcional à extensão e à complexidade do trabalho".

${ }^{222}$ Cf. Artigo $41, \S \S 2^{\circ}$ e $3^{\circ}$.

${ }^{223}$ Cf. Artigo 45, $\S 1^{\circ}$, segundo o qual “o número total de Deputados, bem como a representação por Estado e pelo Distrito Federal, será estabelecido por lei complementar, proporcionalmente à população, procedendo-se aos ajustes necessários, no ano anterior às eleições, para que nenhuma daquelas unidades da Federação tenha menos de oito ou mais de setenta Deputados".

${ }^{224}$ Ronald Dworkin, op. cit., p. 36.

${ }^{225}$ Irene Patrícia Nohara, op. cit., pp. 88 e 89. No mesmo sentido, destaca-se Maurício Zanoide de Moraes, op. cit., p. 344, para quem o crescimento de produção doutrinária a respeito do assunto é bastante
} 
O Supremo Tribunal Federal aceita, já há bastante tempo, o princípio da razoabilidade como importante instrumento de controle de constitucionalidade de leis, além de utilizá-lo como critério de interpretação em casos em que há conflito entre direitos fundamentais. Muito antes da Constituição de 1988, já se podia constatar a aplicação do princípio em alguns julgados, embora de maneira não muito delimitada, mais intuitiva do que técnica.

GILMAR FERREIRA MENDES identifica no recurso especial $\mathrm{n}^{\circ} 18.331$, de relatoria do Ministro Orozimbo Nonato, julgado no ano de 1953, a primeira referência à idéia de proporcionalidade, calcada ainda na noção de excesso ou desvio de poder, a exemplo do que já acontecia na Europa: "O poder de taxar não pode chegar à desmedida do poder de destruir, uma vez que aquele somente pode ser exercido dentro dos limites que o tornem compatível com a liberdade de trabalho, comércio e da indústria e com o direito de propriedade. É um poder, cujo exercício não deve ir até o abuso, o excesso, o desvio, sendo aplicável, ainda aqui, a doutrina fecunda do 'détournement de pouvoir'. Não há que estranhar a invocação dessa doutrina ao propósito da inconstitucionalidade, quando os julgados têm proclamado que o conflito entre a norma comum e o preceito da Lei Maior pode se acender não somente considerando a letra do texto, como também, e principalmente, o espírito do dispositivo invocado" 226 .

Posteriormente, em outros julgados, o Supremo Tribunal Federal utilizou a idéia de proporcionalidade, sendo, todavia, na Representação ${ }^{\circ} 1.077$, de 28 de março de 1984, que se fez primeiramente menção à necessidade de equivalência razoável na contraposição entre um direito do Estado - de exigir o pagamento de taxa judiciária - e o direito do particular - de não se ver demasiadamente lesado em seu pagamento: "Sendo como já se acentuou - a taxa judiciária, em face do atual sistema constitucional, taxa que serve de contraprestação à atuação de órgãos da justiça cujas despesas não sejam cobertas por custas e emolumentos, tem ela - como toda taxa com caráter de contraprestação - um limite, que é o custo da atividade do Estado, dirigido àquele contribuinte. Esse limite, evidentemente, é relativo, dada a dificuldade de se saber, exatamente, o custo dos serviços a que corresponde tal contraprestação. O que é certo, porém, é que não pode taxa dessa natureza ultrapassar uma equivalência razoável entre o custo real dos serviços e o montante

significativa, considerando, ainda, que "a proporcionalidade é um dos temas mais amplos, complexos, e controvertidos no atual estágio dos debates de direitos fundamentais”.

${ }^{226}$ Cf. Gilmar Ferreira Mendes, “O princípio da proporcionalidade...”, cit., p. 364 
a que pode ser compelido o contribuinte a pagar, tendo em vista a base de cálculo estabelecida pela lei e o quantum da alíquota por esta fixado",227.

\subsection{Relação entre os princípios da razoabilidade e proporcionalidade}

Muita discussão se trava na doutrina sobre a relação entre os princípios da proporcionalidade e da razoabilidade.

Seis são as principais diferenças entre os princípios da proporcionalidade e da razoabilidade apontadas por VALESCHKA E SILVA BRAGA: (i) a origem, (ii) o fundamento, (iii) o conteúdo, (iv) os elementos, (v) o nível de objetividade, e (vi) as funções ${ }^{228}$.

A primeira diferença encontra-se na origem de ambos os princípios, tendo sido o princípio da proporcionalidade, como já visto, desenvolvido no direito constitucional alemão, e o da razoabilidade decorrente da evolução da cláusula do due process of law para um subtantive due process of law no direito americano ${ }^{229}$.

Ao longo do tempo, todavia, houve uma aproximação entre os institutos, à medida em que o princípio da proporcionalidade, mais restrito no início, acabou se tornando mais abrangente, enquanto o princípio da razoabilidade, de conteúdo muito mais geral em sua origem, acabou sendo mais especificado com o decorrer do tempo, a partir da sua aplicação pela jurisprudência norte-americana: "A razoabilidade, em sua origem, portanto, possuía uma maior amplitude que a proporcionalidade, tendo a situação se

\footnotetext{
${ }^{227}$ Rp. 1.077, Relator Min. Moreira Alves, RTJ 112:34 (58-59), mencionada por Gilmar Ferreira Mendes, Gilmar Ferreira Mendes, “O princípio da proporcionalidade...”, cit., p. 366.

${ }^{228}$ Op. cit., pp. 124-127.

229 “A razoabilidade encontra utilização singular em sistemas da família da common law. É originária do direito inglês (reasonableness), bastante utilizada no direito norte-americano (na esteira do desenvolvimento da substatntive due process clause), e, por influência deste, está presente no direito argentino, no qual também se outorga á noção uma significação especial.

A proporcionalidade ganha, por sua vez, enorme destaque no desenvolvimento tedesco do princípio, que teve marcada influência na sua disseminação européia, em países como Suíça, Áustria, Espanha, Portugal e Bélgica, onde já se encontram solidamente incorporados, e França e Itália, onde não se logrou ainda um reconhecimento incondicional da máxima" (Cf. José Roberto Pimenta Oliveira, op. cit., pp. 39 e 40).
} 
invertido, e hoje, enquanto a jurisprudência norte-americana tende a limitar a aplicação daquela, a tedesca tende a ampliar cada vez mais a proporcionalidade" 230 .

Outra diferença apontada se impõe quanto ao fundamento. Enquanto o princípio da proporcionalidade encontra seu fundamento no Estado de Direito, o princípio da razoabilidade se funda no devido processo legal. Haveria, assim, diferença no grau de irradiação em relação ao restante do ordenamento jurídico, representando o princípio da proporcionalidade um princípio mais amplo do que o da razoabilidade, que por se embasar em um direito fundamental, não teria o mesmo caráter fundante do Estado Democrático de Direito $^{231}$.

Todavia, esta distinção não tem o alcance esperado, já que, em última instância, todos os direitos fundamentais encontram seu fundamento no Estado de Direito. De acordo com PIMENTA OLIVEIRA, com base em Emiliou, ambos os princípios possuem, ao contrário, um fundamento normativo comum, que é justamente o fato de surgirem junto com a idéia geral de Estado de Direito ${ }^{232}$.

A diferença quanto ao conteúdo, por sua vez, consistiria no fato de que "enquanto a proporcionalidade envolve a compatibilidade dos meios com os fins, a razoabilidade avalia, mais detidamente, a congruência dos motivos (pressupostos de fato) com a finalidade da medida" ${ }^{233}$. Além disso, é apontado, como diferença de conteúdo, o fato de a razoabilidade trabalhar com a idéia de bom senso, voltada apenas à exclusão das condutas tidas como desarrazoadas.

O problema de tal distinção encontra-se, fundamentalmente, na própria extensão que o elemento ou subprincípio da proporcionalidade em sentido estrito tem encontrado na prática, de forma a abarcar também um juízo valorativo entre os fins eleitos e os meios propostos.

\footnotetext{
${ }^{230}$ Valeschka e Silva Braga, op. cit., p. 124.

${ }^{231}$ Idem, p. 125.

232 José Roberto Pimenta Oliveira, op. cit., p. 63.

233 Valeschka e Silva Braga, op. cit., p. 125. No mesmo sentido, conferir Sylvia Marlene de Castro Figueiredo, op. cit., p. 242: "Quanto ao conteúdo: no princípio da proporcionalidade, os elementos da adequação e da necessidade, bem como a conformidade ou proporcionalidade em sentido estrito, realizam-se, tendo em vista a relação meio-fim entre a medida tomada e o fim com ela almejado. No princípio da razoabilidade, em contrapartida, é possível se prescindir da relação meio-fim, levando-se em conta apenas que a decisão jurídica seja racionalmente motivada, ao se analisar os interesses concretos em litígio, adotando-se uma decisão razoável”.
} 
É de se criticar o entendimento de que apenas a proporcionalidade pressupõe o sopesamento entre a medida adotada e a restrição de direitos, enquanto a razoabilidade se contenta apenas com a correlação entre os motivos a finalidade ${ }^{234}$. Isto porque não é admissível ou tida como razoável, em qualquer Estado Democrático de Direito, a busca dos fins de forma desproporcional, ou seja, em grau maior do que o estritamente necessário para obtê-los, idéia que coincide exatamente com a construção doutrinária do conceito da proporcionalidade, especialmente na sua vertente de necessidade ou exigibilidade.

Além do que, a idéia de que a razoabilidade apenas tem o efeito de afastar as condutas tachadas de irrazoáveis, invalidando-as, parte do pressuposto equivocado de que a razoabilidade apenas tem aplicação no âmbito jurisdicional, quando, em verdade, também alcança o processo legislativo, momento em que o princípio da razoabilidade tem precisamente a mesma função positiva comumente apontada como sendo característica da proporcionalidade, que é a de seleção da melhor opção legislativa, afastando a adoção de medidas desarrazoadas.

A diferenciação quanto aos elementos, da mesma forma, já não subsiste com a crescente aproximação entre os conceitos. Se o princípio da proporcionalidade sempre foi tido como diferenciado em sua aplicação por conta de sua segmentação nos subprincípios da adequação, necessidade e proporcionalidade em sentido estrito, enquanto o princípio da razoabilidade era mais abrangente, seguindo uma pauta livre de interpretação, hoje já não se pode mais insistir em tal separação, dado que a jurisprudência americana, sentindo os efeitos de uma interpretação tão ampla ${ }^{235}$, passou a adotar como critérios para a aplicação do princípio da razoabilidade critérios muito próximos aos da adequação, necessidade e proporcionalidade em sentido estrito, quais sejam, os elementos

\footnotetext{
${ }^{234}$ Neste sentido, conferir, por exemplo, Valeschka e Silva Braga, op. cit., p. 104: "Na verdade, entretanto, a proporcionalidade envolve a ponderação entre duas grandezas (a medida administrativa e a restrição imposta ao particular, por exemplo), enquanto a razoabilidade tende a afastar os atos destoantes do bom senso aceitável pelo homem comum.

Ao se aplicar a primeira, sopesa-se os meios empregados para o alcance de determinado objeto (situação jurídica que se almeja obter). Já para a averiguação da razoabilidade, observa-se mais acentuadamente, a correlação entre os motivos (pressupostos de fato e de direito) e a finalidade".

${ }^{235}$ No direito inglês a mesma discussão é percebida, como bem registra José Roberto Pimenta Oliveira, op. cit., p. 76: "Por um lado, a indeterminação deste head of review agasalha o enquadramento de casos não subsumíveis nos demais tipos de vícios, o que permitiu o crescente desenvolvimento e aprofundamento do controle judicial. Por outro lado, a elasticidade com que é manejada e a sua 'fragilidade conceitual' torna a utilização da categoria imprevisível, o que tem suscitado o debate sobre a eventual necessidade de incorporação do princípio da proporcionalidade no direito inglês (como categoria autônoma ou subcategoria da reasonableness), ou mesmo, de pura substituição desta pelo princípio da proporcionalidade (proportionality), no formato alemão".
} 
da o rule of expediency, o balance of convenience, o rule of reasonableness, e o rule of certainty.

Além do que, "não é consenso na doutrina que o 'sopesamento' do proporcional obedeça, na Alemanha, aos três elementos expostos. Na realidade, o desdobramento destes elementos e sua presença no discurso de justificação da decisão tomada acabam cumprindo uma função retórica que esconde a eleição da premissa valorativa e a retira do questionamento jurídico em face da construção de um silogismo baseado em axiomas selecionados" ${ }^{236}$.

Quanto ao nível de objetividade, afirma-se que "os critérios de proporcionalidade são predefinidos, enquanto a razoabilidade possui um conteúdo mais subjetivo, pois envolve a percepção do bom senso admitido pela comunidade, que acaba variando de acordo com os padrões do próprio intérprete" ${ }^{237}$. A respeito, as mesmas observações já feitas sobre a crescente convergência entre os critérios da proporcionalidade e da razoabilidade demonstram que a distância entre os dois princípios é muito mais teórica do que prática.

Por fim, no que se refere às funções, refere-se que o princípio da razoabilidade envolve o "controle dos atos do Poder Público pela exclusão de medida desarrazoada, enquanto o exame da proporcionalidade se dá através da opção pelo meio proporcional, pois, muitas vezes, diante de um conflito, um dos princípios é escolhido por ter precedência contingencial" ${ }^{238}$. Pela escolha da opção mais razoável, automaticamente se estará fazendo a exclusão da opção irrazoável, de forma que a função de ambos os princípios permanece sendo a de vedação do exercício arbitrário pelo Estado, excluindo-se os atos que se mostrem irrazoáveis.

Neste passo, impossível pensar na razoabilidade destituída completamente da proporcionalidade. O que é razoável pode até mesmo ir além do que é proporcional, conter um plus, mas não pode deixar de contemplar o que é proporcional.

Especialmente no que se refere à razoabilidade, a invocação da idéia do “senso comum", não exclui a necessária operação mental da proporcionalidade. Apenas é do senso comum o que é proporcional, e a análise dos critérios adequação, necessidade e proporcionalidade em sentido estrito fica implícita, mas presente, na aplicação da

\footnotetext{
${ }^{236}$ Irene Patrícia Nohara, op. cit., pp. 94 e 95.

${ }^{237}$ Valeschka e Silva Braga, op. cit., p. 126.

${ }^{238}$ Idem, p. 127.
} 
razoabilidade. Tal se dá, como já visto, muito por conta da tradição da common law, em que há uma certa resistência na fixação de critérios e conceitos, pautando-se a atuação do juiz muito mais intuitivamente, e de acordo com precedentes, do que em conformidade com regras pré-determinadas. Nos Estados Unidos, todavia, a utilização de critérios mais ou menos estratificados tem encontrado um espaço cada vez maior.

A melhor percepção parece ser, a partir do que até agora foi exposto, a de que o princípio da razoabilidade contém uma idéia bastante ampla, ligada à idéia de justiça, sendo que cada país desenvolveu uma linha de pensamento de forma a fixar os contornos deste princípio. Assim, a noção de razoabilidade é mais ampla, contendo em si a de proporcionalidade $^{239}$. Só o que é proporcional pode ser considerado razoável, mas nem sempre aquilo que é apenas proporcional será razoável, porque pode não ser adequado ou necessário para alcançar um determinado fim. É o que conclui PIMENTA OLIVEIRA, referindo que a análise da razoabilidade pode ser aferida com base em outros instrumentos, além da proporcionalidade, o que demonstra que esta teria um âmbito um pouco mais ampliado em relação à proporcionalidade ${ }^{240}$.

Esta conclusão é importante para o objetivo de delimitar o significado da garantia razoável duração do processo, porque possibilita a utilização dos critérios da adequação, necessidade, e proporcionalidade em sentido estrito, já bastante desenvolvidos no âmbito do Direito Constitucional, do Direito Administrativo, bem assim no âmbito do Direito Penal, como auxílio na interpretação do que deve ser considerado "prazo razoável de duração do processo", sem, todavia, limitar demasiadamente a análise, permitindo que o justo equilíbrio possa ser alcançado também por outros mecanismos, que podem integrar a idéia de razoabilidade, vindo sempre em acréscimo à noção de proporcionalidade.

\footnotetext{
${ }^{239}$ Neste mesmo sentido, conferir Irene Patrícia Nohara, op. cit., p. 3: “(...) a regra da proporcionalidade é parte da perquirição do razoável, pois a proporção ou a justa medida são critérios necessários para se mensurar o equilíbrio, a moderação ou a racionalidade dos meios para o alcance de determinadas finalidades." Existe também o entendimento oposto, de que o princípio da proporcionalidade seria mais amplo do que o princípio da razoabilidade: "Cremos, outrossim, que o princípio da proporcionalidade possui um 'plus' em relação ao princípio da razoabilidade, uma vez que, com base neste último, o administrador valora situações concretas a lume da razoabilidade (...)" (Sylvia Marlene de Castro Figueiredo, op. cit., p. 246).

240 "Por outro lado, reduzir a razoabilidade à proporcionalidade, princípio estruturado para aferir o controle da adequação, necessidade e proporcionalidade dos atos estatais, à luz das exigências principiológicas e valorativas da Constituição, também retiraria do princípio a força matricial reconhecida em seu núcleo conceitual, que pode ser imposta não apenas pelo recurso à proporcionalidade, mas por outros instrumentos concebidos para coarctar a irregularidade do momento ponderativo inerente ao exercício de certas competências estatais" (Cf. José Roberto Pimenta Oliveira, op. cit., p. 197).
} 


\subsection{Aplicação dos critérios da adequação, necessidade e proporcionalidade em sentido estrito para a fixação de um prazo razoável de duração da persecução penal}

A aproximação conceitual entre os princípios da razoabilidade e da proporcionalidade permite a utilização dos critérios da adequação, necessidade e da proporcionalidade em sentido estrito no que se refere à busca de um significado para a garantia da razoável duração do processo.

A utilização destes mecanismos pode ser de grande utilidade prática para se delimitar o que é "prazo razoável" de duração em cada caso concreto, pois possibilita o sopesamento entre os meios necessários (dilação prazal) para o atingimento de determinados fins (efetivação do jus puniendi e afirmação do jus libertatis) dentro do processo $^{241}$.

Para a aplicação do critério da adequação, que pressupõe, como já visto, uma aptidão do meio para alcançar o fim desejado, deve-se ter em mente se a mera dilação do prazo pode ou não levar ao resultado pretendido. A pergunta a ser formulada, relativamente a esse quesito, deve ser: se o prazo for estendido, conseguirei apurar a autoria e materialidade do crime e, ao mesmo tempo, garantir ao acusado o exercício da ampla defesa?

Como se trata de elemento neutro, no qual apenas se questiona a relação de causalidade entre meio e fim, geralmente a resposta será sim, no que se refere à garantia da razoável duração do processo, pois se todo ato do procedimento colabora para a realização dos fins do processo, e se para a sua realização é necessário tempo, parece evidente que quanto maior for o tempo, mais fácil será chegar ao fim buscado.

Por isso é que, para a análise referente à razoabilidade da dilação de prazo, a pergunta mais importante repousa, precisamente, nos outros dois elementos constitutivos do princípio da proporcionalidade.

A análise acerca da necessidade da dilação do prazo para a realização de determinado fim importa num questionamento valorativo, por meio do qual se questiona a

${ }^{241}$ Teoria do Direito Processual..., cit., p. 169. 
existência de outros meios igualmente aptos e adequados, que poderiam, com menor restrição aos direitos fundamentais, levar ao mesmo resultado.

Um caso prático em que se verifica a aplicação da necessidade como fator de análise da razoabilidade do prazo pode ser encontrado no que se refere a processos em que diversos são os acusados. Conforme orientação jurisprudencial, a dilação do prazo apenas se justifica com base na pluralidade de réus se não houver a possibilidade de desmembramento dos processos ${ }^{242}$. Isto quer dizer que a dilação do processo somente pode ser aceita se absolutamente necessária. Havendo a possibilidade de desmembramento do processo para não prolongar a prisão provisória dos acusados, como, aliás, encontra-se disciplinada no artigo 80 do Código de Processo Penal $^{243}$, não se justifica dilação de prazo com base exclusivamente na justificativa da pluralidade de acusados.

Outro exemplo se observa no que concerne ao prazo necessário para a expedição de cartas precatórias. Não deve haver uma dilação de prazo além do estritamente necessário para o cumprimento da carta precatória, que deverá ser expedida com prazo certo de cumprimento, retomando-se o curso do processo independentemente de sua devolução após o prazo fixado ${ }^{244}$.

Já com relação ao juízo da proporcionalidade em sentido estrito, por meio do qual se realiza, como já observado, uma ponderação entre a magnitude do meio empregado e a relevância e o benefício do fim almejado, igualmente. Mesmo que se esteja diante de um único meio, adequado e necessário para atingir o fim pretendido, se este for demasiado gravoso em relação ao benefício que dele pode advir, deverá ser repudiado, em prol de uma maior proteção aos direitos fundamentais.

242 "Da mesma maneira, a pluralidade de acusados serve como justificativa a uma relativa extensão do procedimento, sempre que conjugado a outros fatores indicadores de complexidade, e desde que não seja possível ou recomendável na hipótese o desmembramento dos autos. Havendo a possibilidade de desmembramento, não há justificativa para o excesso de prazo em razão da pluralidade de réus no processo" (Cf. Maria Thereza Rocha de Assis Moura e Thaís Aroca Datcho Lacava, "A garantia da razoável duração do processo penal e a contribuição do STJ para a sua efetividade”, in: Geraldo Prado e Diogo Malan (coord.), , Processo Penal e Democracia: Estudos em Homenagem aos 20 anos da Constituição da República de 1988, Rio de Janeiro, Lumen Juris, 2009, p. 413).

\footnotetext{
243 "Será facultativa a separação dos processos quando as infrações tiverem sido praticadas em circunstâncias de tempo ou de lugar diferentes, ou, quando pelo excessivo número de acusados e para não lhes prolongar a prisão provisória, ou por outro motivo relevante, o juiz reputar conveniente a separação".

${ }^{244}$ Vale citar aqui o que restou consignado pela Quinta Turma do Superior Tribunal de Justiça quando do julgamento do habeas corpus $n^{\circ} 87883 / \mathrm{RN}$, de relatoria do Ministro Napoleão Nunes Maia Filho, julgado em 13/12/2007 e publicado em 07/02/2008: “ao expedir carta precatória a fim de inquirir testemunhas, deve o juízo deprecante fixar prazo razoável para a sua devolução e, uma vez ultrapassado, é de rigor a retomada do curso do processo, podendo aquela prova ser sopesada em qualquer fase ou grau de jurisdição".
} 
Hipótese em que esta ponderação é empregada para o fim de afastar a dilação do processo além de determinado limite, refere-se à consideração do quantum de pena a ser aplicado em caso de condenação em relação ao tempo de duração do processo.

Se a pena a ser aplicada ou que já foi aplicada em primeiro grau aproximase do tempo de duração do próprio processo, é sinal de que o meio, por mais que seja adequado e necessário, revela-se excessivo, desproporcional, enfim, irrazoável em relação ao fim material buscado, que, em caso de condenação, é a aplicação da pena ${ }^{245}$.

A análise da razoabilidade do prazo não pode prescindir, ainda, de um exame de legalidade, a exemplo do rule of certainty, que aparece na construção norteamericana do princípio da razoabilidade. O rule of certainty determina que para qualquer restrição a direitos fundamentais é necessário haver uma lei, prévia, determinada e escrita autorizando-a. Aliás, o próprio princípio da razoabilidade decorreu, nos Estados Unidos, do devido processo legal, portanto, absolutamente incindível do princípio da legalidade.

A soma aritmética dos prazos de cada ato processual que compõe o procedimento é um critério que tem sido cada vez mais afastado por sua insuficiência e desconformidade com a realidade, mas que não pode ser menosprezado de forma alguma pelo intérprete.

O prazo resultante da soma dos atos processuais ainda que insuficiente, por si só, para determinar a duração da persecução penal como um todo, deve ser assumido

\footnotetext{
${ }^{245}$ A utilização do princípio da proporcionalidade, especialmente do critério da proporcionalidade em sentido estrito para aferição da razoabilidade de duração do processo, pode ser visto com clareza no seguinte aresto do Superior Tribunal de Justiça, no qual se consignou: “(...) Ademais, a dilação existente entre a data da prolação da sentença - 23 de dezembro de 2005 e o julgamento da apelação - até agora sem previsão, passados quase 2 anos, e principalmente, considerando que passou mais de um ano apenas entre a prolação da sentença e a interposição de apelação pelo Ministério Público, revelam a falta de atuação do Poder Judiciário no sentido de promover a realização da garantia da razoável duração do processo, que não se limita apenas ao momento da prolação da sentença, mas que claramente alcança toda a persecução penal, garantindo ao acusado a solução em caráter definitivo de sua situação processual em um prazo razoável. A noção de razoabilidade remete automaticamente à noção de proporcionalidade, em que devem ser analisados os critérios de adequação, necessidade e a proporcionalidade em sentido estrito da restrição da liberdade. No caso ora sob exame, maior perplexidade surge da percepção de que a pena aplicada em primeira instância foi de apenas 3 anos e 8 meses, em regime inicial semi-aberto, e de que o paciente já se encontra recluso provisoriamente há quase três anos! Desproporcional, portanto, a medida. Com recurso do Ministério Público, admite-se a possibilidade de agravamento da reprimenda e por isso não é deferido ao paciente a antecipação dos efeitos da sentença nem mesmo para fins de progressão de regime. E a esse respeito não há outra solução. Todavia, há que ser confiado ao paciente que aguarde a solução do desfecho em liberdade, já que, se improcedente o recurso ministerial, o paciente estaria preso há mais tempo do determinaria a sua própria pena" (HC 81996/PE, Sexta Turma, Rel. Min. Maria Thereza de Assis Moura, j. 29/11/2007, DJ de 17/12/2007, p. 349). Em sentido semelhante: TJRJ, HC 2008.059.07635, Oitava Câmara, Rel. Des. Gilmar Augusto Teixeira, j. 27/11/2008: "Ocorre que se nos afigura desproporcional e desarrazoada a permanência de alguém preso provisoriamente por tempo superior à pena mínima imposta ao crime a que está sendo processado, mesmo considerando a continuidade delitiva imputada".
} 
como um referencial importante, apenas se concebendo a sua extrapolação nos casos em que o procedimento em concreto se afaste do modelo legal de procedimento, isto é, quando o procedimento, por suas peculiaridades, demandar a realização de atos processuais adicionais, para os quais não seja previsto prazo, ou pressuponha, por sua complexidade, a necessidade de maior prazo para o seu desenvolvimento.

Há, por fim, um critério vago, correspondente ao "senso geral de justiça", que pode ser utilizado pelo intérprete - desde que sempre favor rei ou favor libertatis - em casos em que, mesmo que atendidos todos os demais critérios, ainda assim, a restrição se mostre ilegítima, afrontando uma idéia ordinária sobre o sentido da própria justiça. Tratase de uma válvula de escape, ou seja, de critério poroso o suficiente para ser utilizado em prol do indivíduo quando as peculiaridades do caso concreto demonstrem afronta à razoabilidade.

A consciência da existência de tais critérios que integram o significado de "razoabilidade" pode trazer benefícios à efetividade da garantia da razoável duração do processo, diminuindo o grau de incerteza em relação à vagueza semântica do termo e auxiliando na tarefa jurisdicional. 


\section{NOÇÃO DE PRAZO: FIXAÇÃO DOS TERMOS INICIAL E FINAL PARA A CONTAGEM DO PRAZO RAZOÁVEL DE DURAÇÃO DA PERSECUÇÃO PENAL}

Como já ressaltado no capítulo 3, para se definir qual é o prazo razoável de duração da persecução penal, é preciso lidar com as noções de razoabilidade e de prazo, ambas indispensáveis para se buscar o significado e o alcance da garantia prevista no artigo $5^{\circ}$, inciso LXXVIII.

No que se refere à noção de prazo, as questões que se colocam se referem principalmente à definição dos momentos inicial e final de sua contagem, assim como das etapas da persecução penal nas quais incide a garantia.

A preocupação com a duração do processo penal sempre foi mais voltada ao

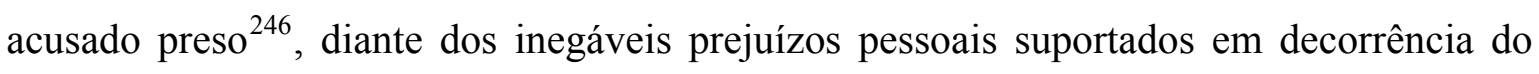
encarceramento. Foi para restringir a duração da prisão cautelar que surgiu o critério jurisprudencial da soma dos prazos dos atos processuais do procedimento aplicável aos crimes apenados com reclusão, conhecido como critério dos "81 dias". Estipulou-se que o prazo de duração da prisão deveria ser contado desde efetivação da custódia, momento em que o acusado passa a sentir os efeitos do encarceramento, até a prolação da sentença de primeiro grau, quando há, na maioria dos casos, a primeira manifestação do Estado sobre o mérito da acusação.

${ }^{246}$ Cf. Aury Lopes Jr. e Gustavo Henrique Righi Ivahy Badaró, op. cit., p. 83. 
Esse critério dos 81 dias sofreu modificações ao longo dos anos, com a progressiva alteração do limite final da contagem do prazo para fins de alegação de excesso de prazo da prisão cautelar, como adiante se demonstrará mais detidamente.

Com relação ao acusado solto, apenas no âmbito da justiça castrense houve preocupação por parte do legislador em estipular um prazo para o término da instrução criminal em relação ao acusado solto, e isto já em outubro de 1969, antes mesmo da Convenção Americana de Direitos do Homem. Nos termos do artigo 390 do Código de Processo Penal Militar, "o prazo para a conclusão da instrução criminal é de cinqüenta dias, estando o acusado preso, e de noventa, quando solto, contados do recebimento da denúncia”. Este prazo poderia ser estendido em algumas hipóteses específicas, de acordo com o parágrafo primeiro do mesmo artigo, tais como doença do acusado ou de seu defensor, necessidade de expedição de carta precatória para a inquirição de testemunhas, realização de exames periciais e de outras diligências necessárias à instrução criminal ${ }^{247}$. A dilação necessária para a realização destes atos deve, em qualquer hipótese, ater-se aos prazos legais previstos especificamente para cada um deles.

Atualmente, com a previsão da garantia da razoável duração do processo expressa no texto constitucional, impõe-se a limitação da duração do processo também com relação ao acusado solto, especialmente diante da estigmatização social sofrida e da angústia em relação ao resultado final do processo ${ }^{248}$.

Passar-se-á, assim, ao estudo dos limites inicial e final, isto é, do dies a quo e do dies ad quem do prazo razoável de duração do processo, válido não para fins de desencarceramento, mas para fins de efetiva prestação da tutela jurisdicional, no campo processual penal.

\footnotetext{
${ }^{247}$ Art.390, §1 ${ }^{\circ}$ : "Não será computada naqueles prazos a demora determinada por doença do acusado ou defensor, por questão prejudicial ou por outro motivo de força maior justificado pelo auditor, inclusive a inquirição de testemunhas por precatória ou a realização de exames periciais ou outras diligências necessárias à instrução criminal, dentro dos respectivos prazos".

248 “(...) a questão da dilação indevida do processo também deve ser reconhecida quando o imputado está solto, pois ele pode estar livre do cárcere, mas não do estigma e da angústia. É inegável que a submissão ao processo penal autoriza a ingerência estatal sobre toda uma série de direitos fundamentais, para além da liberdade de locomoção, pois autoriza restrições sobre a livre disposição de bens, a privacidade das comunicações, a inviolabilidade do domicílio e a própria dignidade do réu" (Aury Lopes Jr., "A (de)mora jurisdicional no processo penal: o direito a um processo sem dilações indevidas". In: Revista de Estudos Criminais, ano IV, $\mathrm{n}^{\circ} 5,2004$, p. 68).
} 
Especialmente, na primeira fase da persecução penal, a fase investigatória, há controvérsia sobre o início da contagem do prazo, já que há uma imprecisão sobre o momento em que surge a figura do investigado ou imputado, quando se pode afirmar que há um direito à razoável duração do processo.

Quanto ao marco final, igualmente, há dificuldade de identificação do momento em que cessa a exigência de razoabilidade da duração do procedimento, havendo quem entenda que a fase recursal não está englobada nesse prazo.

\subsection{Garantia do término da investigação criminal num prazo razoável}

\subsubsection{Marco inicial para a contagem do prazo: notitia criminis ou fixação do sujeito passivo na investigação criminal?}

De início, é de se perquirir se a garantia da razoável duração do processo é aplicável apenas à ação penal, quando há uma acusação formal oferecida contra o acusado, ou se alcança também a investigação criminal.

Com a redação dada ao inciso LXXVIII da Constituição da República pela Emenda $\mathrm{n}^{\circ} 45$, que emprega a expressão "a todos, no âmbito judicial e administrativo, são assegurados a razoável duração do processo", fica bastante claro que também o inquérito policial se encontra no âmbito de incidência da garantia em questão ${ }^{249}$.

Considerando que a investigação criminal traz tantos inconvenientes e estigmatização para o sujeito passivo quanto a própria ação penal, justifica-se plenamente que essa fase preliminar tenha duração certa e razoável.

\footnotetext{
249 "Primeiramente, diga-se que o referido inciso LXXVIII, inserido na Constituição Federal pela Emenda Constitucional $\mathrm{n}^{\circ} 45$, ao mencionar expressamente o 'âmbito administrativo', parece afastar de forma inconstestável que a 'razoável duração do processo' ali aludida se refira exclusivamente a processos judiciais. Nesse diapasão, o inquérito policial, ou mesmo as investigações preliminares que o antecedem, como é o caso concreto existente no texto, entendidos como procedimentos administrativos informativos com a função de subsidiar uma futura ação penal, estão, sim, submetidos à previsão contida no referido artigo, devendo ter uma 'duração razoável"' (Déllio Lins e Silva Júnior, "O trancamento do inquérito policial pela falta de razoabilidade no prazo de sua duração", Boletim do IBCCrim n ${ }^{\circ} 160$, ano 13, março de 2006, p. 4).
} 
Outra não é a conclusão que se extrai da leitura do artigo 7.5 do Pacto de São José da Costa Rica, segundo o qual "toda pessoa detida ou retida deve ser conduzida, sem demora, à presença de um juiz ou oura autoridade autorizada pela lei a exercer funções judiciais e tem direito a ser julgada dentro de um prazo razoável ou a ser posta em liberdade, sem prejuízo de que prossiga o processo". Trata-se de garantia que atinge, portanto, por toda a persecução penal, desde o momento em que é imputada a prática de um crime a uma pessoa, até o momento em que esta é definitivamente julgada.

Daí porque é preferível a nomenclatura "razoável duração da persecução penal", em lugar de "razoável duração do processo penal", pois assim se engloba não apenas a ação penal, mas também a investigação e a própria execução penal, como adiante se verá ${ }^{250}$, afastando-se a idéia limitativa que a expressão "processo" traz, contrária à própria intenção do legislador.

Dois são os possíveis marcos iniciais para a contagem do prazo: o início do procedimento com o ato formal que lhe instaura, a partir da notitia criminis, ou, ainda, o momento em que o sujeito passivo é delimitado no âmbito da investigação.

A notitia criminis marca o início da investigação criminal, pois apenas quando o cometimento de um crime chega ao conhecimento da autoridade policial é que esta pode tomar providências para a sua elucidação ${ }^{251}$. Já a delimitação do sujeito passivo no âmbito da investigação criminal varia em cada ordenamento jurídico, podendo se verificar com a realização de diferentes atos processuais, tais como a prisão em flagrante ou outra forma de prisão cautelar, o interrogatório, o indiciamento, a execução de medidas cautelares diversas, a própria abertura do inquérito policial, nos casos em que referido procedimento for instaurado contra pessoa certa, etc.

\subsubsection{Portugal}

\footnotetext{
${ }^{250}$ Conferir, a respeito, o item 5.2.3.3.

${ }^{251}$ Por razões óbvias, muitos são os crimes cometidos de forma dissimulada, escondida, já que o criminoso em regra não quer ser descoberto, seja para frustrar a própria conduta criminosa, seja para se furtar à sanção penal, tanto que, para alguns crimes o prazo prescricional, somente começa a ser contado do momento em que toma conhecimento de sua prática, como é o caso dos crimes de bigamia e nos de falsificação ou alteração de assentamento do registro civil (artigo 111, IV, do Código Penal).
} 
O Código de Processo Penal português traz como marco para o lapso temporal próprio da investigação a condição de argüido, que se instaura nas seguintes situações: quando a pessoa contra a qual corre a investigação presta declarações perante a autoridade policial ou judiciária; quando for aplicada contra a pessoa qualquer medida cautelar, inclusive de natureza meramente patrimonial; quando a pessoa é detida; em face de notitia criminis que dê o indivíduo como sujeito de um crime, salvo se esta for manifestamente infundada ${ }^{252}$.

O critério utilizado pelo sistema português para a delimitação do sujeito passivo na investigação é, como se pode perceber, o momento em que uma pessoa passa a sofrer os efeitos de uma investigação criminal em sua esfera de direitos, o que ocorre desde o momento em que tem seu nome vinculado a um procedimento investigativo de natureza criminal (efeitos de estigmatização social), até o momento em que sofre qualquer tipo de intervenção em sua esfera patrimonial, liberdade de locomoção ou qualquer outro direito fundamental.

Qualquer suspeito pode, aliás, no curso da investigação, pedir que seja constituído na condição de argüido quando estiverem prestes a serem realizadas diligências que lhe possam afetar, para com isso contar com a proteção formal de seus direitos, inclusive com a intervenção de advogado em seu favor ${ }^{253}$.

Trata-se de sistema elogiado pela doutrina, por definir de maneira clara e definida o momento em que alguém passa a ser considerado como sujeito passivo da investigação $^{254}$.

\footnotetext{
${ }^{252}$ Artigo 58 do Código de Processo Penal português: “1 - Sem prejuízo do disposto no artigo anterior, é obrigatória a constituição de arguido logo que: a) Correndo inquérito contra pessoa determinada, esta prestar declarações perante qualquer autoridade judiciária ou órgão de polícia criminal; b) Tenha de ser aplicada a qualquer pessoa uma medida de coacção ou de garantia patrimonial; c) Um suspeito for detido, nos termos e para os efeitos previstos nos artigos $254 .^{\circ}$ a $261 .^{\circ}$; ou d) For levantado auto de notícia que dê uma pessoa como agente de um crime e aquele lhe for comunicado".
}

${ }^{253}$ Cf. artigo 59 do Código de Processo Penal português, com a seguinte redação: 1 - Se, durante qualquer inquirição feita a pessoa que não é arguido, surgir fundada suspeita de crime por ela cometido, a entidade que procede ao acto suspende-o imediatamente e procede à comunicação e à indicação referidas no $\mathrm{n}^{\circ}{ }^{\circ} 2$ do artigo anterior. 2 - A pessoa sobre quem recair suspeita de ter cometido um crime tem direito a ser constituída, a seu pedido, como arguido sempre que estiverem a ser efectuadas diligências, destinadas a comprovar a imputação, que pessoalmente a afectem".

${ }^{254}$ Aury Lopes Jr., Sistemas de investigação preliminar no processo penal, $2^{\mathrm{a}}$ ed., Rio de Janeiro, Lumen Juris, 2003, p. 321. 


\subsubsection{Espanha}

No sistema espanhol, delimita-se o sujeito passivo da investigação criminal a partir de qualquer ato que faça presumir a imputação de um delito, nominando-se especificamente a detenção, a qualquer título, e a submissão a qualquer tipo de medida cautelar. Nos termos do artigo 118 do Código de Processo Penal: "Toda pessoa a quem se impute um ato punível poderá exercitar o direito de defesa, atuando no procedimento, qualquer que seja este, desde que lhe comunique sua existência, tenha sido objeto de detenção ou de qualquer outra medida cautelar. A admissão de uma notícia-crime ou qualquer atuação policial ou do Ministério Público, da qual resulte a imputação de um delito contra uma pessoa ou pessoas determinadas, será levada imediatamente ao seu conhecimento. Para exercitar o direito de defesa, a pessoa interessada deverá designar um defensor, e, não o fazendo, deverá ser-lhe nomeado um, que o assistirá em todos os atos da instrução preliminar”.

O sistema espanhol garante, ainda, uma notificação formal a todo o indivíduo contra o qual se impute um crime, para que este possa, na qualidade de sujeito passivo da investigação, exercitar o seu direito de defesa desde logo.

\subsubsection{Argentina}

$\mathrm{Na}$ mesma esteira do que se verifica na legislação processual espanhola, a Argentina adota em seu Código de Processo Penal Nacional um marco geral, que engloba como sujeito passivo da investigação criminal toda pessoa que for indicada como partícipe de um delito, independentemente de acusação formal, garantindo esse marco a incidência de todas as garantias constitucionais no âmbito da investigação criminal.

Eis a redação do seu artigo 71 que expressa essa opção legislativa: "Qualquer pessoa que seja indicada de qualquer modo como partícipe de um fato delitivo poderá fazer valer os direitos que o Código prevê para o imputado". 


\subsubsection{Tribunal Europeu de Direito Humanos}

O entendimento do Tribunal Europeu de Direitos Humanos tem sido também o de considerar como marco inicial para a contagem do prazo inicial da persecução penal a condição de "acusado em geral", ou seja, sempre que uma pessoa for apontada como provável autora de determinado crime.

No julgamento do caso Wemhoff, cidadão alemão acusado de praticar fraudes contra o sistema financeiro com conseqüências internacionais, ficou consignado o entendimento da Corte européia de direitos humanos de que "o prazo de duração razoável do procedimento penal se computa a partir das primeiras indicações ou denúncias formuladas oficialmente contra o imputado" 255 .

A mesma linha de pensamento se manteve nos julgamentos seguintes, valendo citar, ainda, o caso Neumeister, cidadão austríaco acusado da prática de crimes contra a ordem tributária, no qual a Comissão opinou no sentido de que a contagem do início do prazo deveria se dar apenas a partir do momento em que "os indícios contra um pessoa passam a repercutir gravemente em sua situação pessoal" ${ }^{256}$, escolhendo o momento do interrogatório como marco.

Todavia, o Tribunal considerou que o início do prazo deveria ser contabilizado a partir do momento em que o Ministério Público concordou com a abertura do procedimento investigatório contra Neumeister, frisando, mais uma vez, o seu entendimento de que o início do prazo "começa necessariamente no dia em que se acusa alguém" 257 .

Por fim, é de registrar, ainda, o caso Eckle, que ajudou a firmar a orientação já exposta, esclarecendo ainda mais a posição do Tribunal. Neste caso, as investigações a respeito dos crimes cometidos por Hans Eckle e sua esposa (supostas fraudes cometidas para conseguirem empréstimo frente a instituições financeiras) se desenrolaram por bastante tempo, sem a individualização da autoria dos fatos. A despeito disso, somente

\footnotetext{
${ }^{255}$ Daniel R. Pastor, El plazo razonable.., cit., p. 115.

${ }^{256}$ Idem, p. 119.

${ }^{257}$ Idem, pp. 120-121.
} 
quando testemunhas foram ouvidas e começaram a referir o nome do casal e apresentar denúncias contra os investigados, é que o prazo passou a ser considerado ${ }^{258}$.

O marco escolhido foi, neste caso, o primeiro ato de comunicação dos investigados no curso da investigação, demonstrando a tendência internacional em se considerar como termo inicial da garantia sempre um momento relativo a uma valoração ou individualização da autoria ${ }^{259}$, não meramente de fummus delicti comissi.

\subsubsection{Corte Interamericana de Direito Humanos}

A Corte Interamericana de Direitos Humanos, a seu turno, segue muito de perto a orientação do seu correspondente europeu, ao considerar que "em matéria penal, este prazo começa quando se apresenta o primeiro ato de procedimento dirigido contra determinada pessoa como responsável por certo delito" 260 .

Um dos julgamentos mais relevantes realizados no âmbito da Corte Interamericana de Direitos Humanos no que se refere à fixação do momento inicial de contagem do prazo razoável de duração do processo foi o caso Tibi versus Equador, realizado em 7 de setembro de 2004. Daniel Tibi era comerciante de pedras preciosas e foi detido quando conduzia seu automóvel em uma rua de Quito, capital equatoriana. Ficou preso ilegalmente por 28 meses, foi torturado em diversas ocasiões, golpeado, queimado e asfixiado até que confessasse a sua participação em uma quadrilha ligada ao narcotráfico.

Neste caso, a Corte Interamericana repisou o entendimento, que até então já vinha adotando, de que "o prazo razoável deve calcular-se a partir do primeiro ato do processo penal", considerando, no caso concreto, que este primeiro ato se deu com a prisão do acusado, que foi o primeiro ato realizado na investigação contra Daniel Tibi.

Frisou, nesta mesma ocasião, que, com a prisão ou detenção do indivíduo, fica claro o marco inicial de contagem, mas nem sempre ela é suficiente. Nesse sentido, afirmou: "Dizer que o prazo razoável corre a partir da detenção do investigado não conduz

\footnotetext{
${ }^{258}$ Idem, pp. 145-146.

${ }^{259}$ Fauzi Hassan Choukr, op. cit., p. 162.

${ }^{260}$ Caso López Alvarez versus Honduras, sentença de $1^{\circ}$ de fevereiro de 2006.
} 
a uma solução satisfatória para todos os casos. Em realidade, é possível que antes desse momento tenha se desenvolvido um procedimento investigatório, inclusive judicial, de larga duração. Durante esse, houve já pressão sobre o sujeito e opressão a seus direitos"261.

A mesma decisão trouxe, ainda, de relevante para o tema ora sob estudo, a observação de que a interpretação com relação a esse momento inicial da contagem do prazo deve ser feita sempre no sentido de proteger os direitos do investigado, já que o tempo durante o qual se submete a uma investigação "é um tempo de redução, compressão, suspensão de direitos", elogiando, ainda, a iniciativa legislativa de países que compreenderam a necessidade de fixar um prazo de duração desta primeira fase da persecução penal.

\subsubsection{Brasil}

O início da contagem com base na notitia criminis é o sistema adotado no Brasil $^{262}$, já que não há nenhum dispositivo legal versando sobre o início da contagem do prazo da investigação. Há apenas a previsão, em linhas gerais, de um prazo para a sua conclusão. Nos termos do artigo 10 do Código de Processo Penal, “o inquérito deverá terminar no prazo de 10 dias, se o indicado tiver sido preso em flagrante, ou estiver preso preventivamente, contado o prazo, nesta hipótese, a partir do dia em que se executar a ordem de prisão, ou no prazo de 30 dias, quando estiver solto, mediante fiança ou sem ela".

A redação, aliás, é bastante confusa, dela se extraindo a conclusão de que o início para a contagem do prazo no caso em que há a imposição de prisão preventiva se dá com a execução do mandado de prisão, o que traz perplexidade, já que se a prisão for determinada e cumprida, por exemplo, no $30^{\circ}$ dia, a investigação teria o prazo prorrogado para mais 10 dias, chegando a 40 dias de duração, sem justificativa para tal diferenciação.

No Código de Processo Penal Militar, o momento inicial de contagem do prazo para a conclusão do inquérito é posto da seguinte forma: no caso de indiciado preso,

\footnotetext{
${ }^{261}$ Sentença de 7 de setembro de 2004.

${ }^{262}$ Nesse sentido, Fauzi Hassan Choukr, op. cit., p. 162.
} 
o prazo começa a contar a partir da execução da ordem de prisão, e, no caso de indiciado solto, a partir da instauração do inquérito ${ }^{263}$.

Igual conclusão se extrai da leitura do procedimento especial previsto na nova Lei de Entorpecentes (Lei 11.343/06), que tampouco estipula o marco inicial da contagem na investigação, limitando-se a fixar o prazo de conclusão do inquérito policial em 30 dias, se o indiciado estiver preso, e em 90 dias, se estiver solto, duplicáveis os prazos pelo juiz, se houver pedido justificado da autoridade policial.

A Lei 5.010/66, de igual modo, apenas prevê prazo para a conclusão do inquérito policial de quinze dias, quando o indiciado estiver preso, nos casos em que se investigar crime da competência da Justiça Federal. Este prazo pode, ainda, ser prorrogado pelo juiz por mais quinze dias, a pedido, devidamente fundamentado, da autoridade policial.

Assim, depreende-se que o marco inicial de contagem do prazo razoável de duração do processo (e não da prisão) no sistema brasileiro coincide com a própria instauração do procedimento investigatório.

O problema deste sistema, acolhido no ordenamento brasileiro, é que nem sempre é possível fixar um sujeito passivo em tão pouco tempo. Há casos em que a Polícia Judiciária leva diversos anos até conseguir alguma pista sobre quem poderia ter sido o autor de um determinado crime. Em algumas situações, há a necessidade de perícias demoradas, ou há receio por parte das testemunhas em depor sobre o crime, dificultando o trabalho da autoridade policial. Por outro lado, há situações em que uma investigação se inicia e termina sem que tenha sido individualizado um provável autor ${ }^{264}$.

\footnotetext{
263 Conforme artigo 20: “O inquérito deverá terminar dentro em vinte dias, se o indiciado estiver preso, contado esse prazo a partir do dia em que se executar a ordem de prisão; ou no prazo de quarenta dias, quando o indiciado estiver solto, contados a partir da data em que se instaurar o inquérito".
}

\footnotetext{
264 “Inobstante, não ocorre o mesmo na investigação preliminar, que, como fase pré-processual, de caráter preparatório, pode nascer, desenvolver-se e inclusive ser concluída sem que exista um sujeito passivo. Uma das principais funções da instrução preliminar é a de descobrir quem é o autor do delito, que passará a ser parte passiva no processo, de modo que não é imprescindível para a existência da fase pré-processual" (Cf. Aury Lopes Jr., Sistemas de investigação..., cit., p. 280).
} 
O prazo máximo de duração do procedimento investigatório deverá ser, em tais situações, o prazo da prescrição, a partir do qual não há mais o jus puniendi por parte do Estado. Enquanto não há um provável agente, o único interesse envolvido é o do Estado, que pode utilizar-se de todos os meios que lhe estiverem licitamente ao alcance para perquirir sobre a autoria de um fato em tese criminoso.

Assim, o momento mais propício para marcar o início da contagem do prazo de duração da investigação criminal é aquele em que começa a pesar uma acusação (em sentido amplo) contra um determinado indivíduo. Pode ocorrer, aliás, que coincidam os momentos da notitia criminis e da individualização do sujeito passivo, como no caso de prisão em flagrante, em que se evidencia, desde logo, o provável autor, pela própria visualidade do crime, e da representação para a instauração do inquérito policial na qual a notícia do crime venha acompanhada da indicação do provável autor do crime noticiado.

O status do sujeito passivo varia no decurso da persecução penal à medida em que varia o grau do juízo de certeza quanto a sua autoria. Há uma gradação entre as figuras do suspeito, do indiciado e do condenado. Com relação ao suspeito, o juízo é de mera possibilidade. Os suspeitos são as pessoas que não podem, a priori, ser excluídas como agentes do ilícito penal, mas contra as quais não se pode sustentar uma acusação. Com relação ao indiciado, o juízo é de probabilidade. Contra o indiciado já se reúnem indícios de que seja ele o autor do fato, sendo isto não mais apenas possível, mas provável. As razões que levam a crer ser ele o autor do fato superam as razões que levam a crer não ser ele o autor do fato ${ }^{265}$. Finalmente, com relação ao condenado, há um juízo de certeza,

265 “A mera suspeita não vai além da conjetura, fundada em entendimento desfavorável a respeito de alguém. As suspeitas, por si sós, não são mais que sombras; não possuem estrutura para dar corpo à prova da autoria. Nada aproveitam para a instrução criminal; apenas importam à simples investigação policial.

Suspeita-se de pessoas, de coisas, de fatos. Suspeita-se com vistas a circunstâncias. O suspeitador olha do alto, conjetura, desconfia, possui leve opinião subjetiva a respeito do objeto. Suspeitar é, supondo, tachar de duvidosa a pessoa, a coisa, ou o fato.

Diferem, segundo a razão, as figuras do suspeito e do indiciado. Existem dois juízos, quanto à autoria, na fase procedimental da persecutio criminis, a saber: do possível e do provável.

Juízo possível consiste naquele que, logicamente, não é contraditório. Inexistem motivos fortes pró ou contra. Emerge neutral, assim: é possível que o homem seja homicida, mas é possível que não seja. Aflora como suspeito.

Juízo provável é o verossímil. Aproxima-se da verdade, sem necessariamente ser verdadeiro. Parte de razões robustas, porém, ainda não decisivas. Não bastante suficientes, senão para imputar. Surge aneutral, assim: é provável que o homem seja homicida, por causa dos meios de prova colhidos ou produzidos, mas, talvez não seja. Deve, portanto, ser indiciado.

Indiciado, assim, é aquele sobre quem recaiam, no correr do inquérito policial, os indícios, ou outros meios de prova, bastantes para acusar em juízo, de haver perpetrado infração penal, cuja existência se acha suficientemente evidenciada" (Sérgio Marcos de Moraes Pitombo, op. cit., pp. 39 e 40). 
que não é absoluta, mas uma certeza moral, processualmente atingível ${ }^{266}$. Com a sentença penal condenatória ${ }^{267}$, a autoria do sujeito passivo é tida como certa.

Há autores que consideram que o indiciamento deveria ser tido como um marco bem delineado no curso da investigação criminal, delimitando o momento exato em que o indivíduo passa, de mero suspeito, a provável autor do fato ${ }^{268}$.

O principal problema, todavia, de se adotar o indiciamento como marco inicial de contagem do prazo de duração da investigação criminal repousa na absoluta falta de disciplina desse instituto em nosso ordenamento jurídico. A idéia de que o indiciamento precisa ser melhor regulamentado pela lei processual penal, destacando-o como ato formal e motivado da polícia judiciária, faz parte de reivindicação da doutrina, especialmente na figura de PITOMBO $^{269}$.

Acresça-se a toda essa problemática, a existência de prática policial consistente em se postergar o momento do indiciamento como forma de prejudicar a adequada realização do direito de defesa no inquérito policial ${ }^{270}$. Não são raros os casos, aliás, que um indivíduo vem a ser acusado sem ter sido indiciado na fase policial, o que é incompatível com a lógica do sistema, pois se há elementos para acusar, já havia elementos suficientes para o indiciamento formal no âmbito da investigação ${ }^{271}$.

\footnotetext{
${ }^{266}$ Neste sentido, Maria Thereza Rocha de Assis Moura, para quem a certeza obtida com a sentença penal condenatória nunca chega a ser absoluta, tratando-se de uma "certeza moral", em A prova por indícios no Processo Penal, Saraiva, São Paulo, 1994, p. 97.

${ }^{267}$ E, aqui, inclui-se a sentença conhecida como "absolutória imprópria”, pois, embora haja uma absolvição, é aplicada a medida de segurança - que, afinal, constitui uma sanção negativa - a um sujeito determinado tido como autor certo do delito.

${ }^{268}$ Nesse sentido, ver Sérgio Marcos de Moraes Pitombo, op. cit., pp. 39 e 40.

${ }^{269}$ Idem, p. 44. Destaca-se, ainda, adotando igual entendimento em relação ao assunto, Aury Lopes Jr., Sistemas de investigação..., cit., p. 271.
}

270 "Ademais, diante dessa grave lacuna, é práxis policial deixar o indiciamento para o final do inquérito, quando da elaboração do relatório, evitando, assim, que o sujeito passivo assuma a posição de indiciado e receba a proteção que a Constituição assegura a ele" (Aury Lopes Jr. e Gustavo Henrique Righi Ivahy Badaró, op. cit., p. 92). Sobre esta prática, ver mais a respeito em Marta Saad, op. cit., pp. 257-258.

${ }^{271}$ Nas palavras de Aury Lopes Jr., Sistemas de investigação..., cit., p. 269, trata-se de verdadeira “aberração jurídica”, reinando, enfim, “a mais absoluta incerteza, em inequívoco detrimento da sua situação jurídica, do seu status libertatis e da sua própria dignidade pessoal". Tal se constata, ademais, a partir de simples pesquisa jurisprudencial, em que se verifica a existência de ampla casuística em que o indiciamento é determinado após o oferecimento da denúncia, reconhecendo-se, nestes casos, o constrangimento ilegal. Neste sentido, os seguintes julgados do Superior Tribunal de Justiça: HC 107361/SP, Quinta Turma, Rel. Min. Felix Fischer, j. 16/09/2008, DJ de 03/11/2008; HC 84142/SP, Quinta Turma, Rel. Min. Napoleão Nunes Maia Filho, j. 03/11/2008, DJ de 28/04/2008; HC 82497/SP, Sexta Turma, Rel. Min. Maria Thereza 
Se o indiciamento antecipado, sem que existam ainda indícios suficientes de autoria configura constrangimento ilegal, impugnável por meio de habeas corpus ${ }^{272}$, também o seu uso tardio, com o intuito de frustrar o exercício do direito de defesa pelo suspeito, constitui um desvirtuamento impugnável pelo remédio heróico ${ }^{273}$.

O projeto de Lei 4.209/2001 propõe a seguinte redação para o artigo $8^{\circ}$ do Código de Processo Penal, ao dispor que "reunidos os elementos informativos tidos como suficientes, a autoridade policial cientificará o investigado, atribuindo-lhe, fundamentadamente, a situação jurídica de indiciado, com as garantias dela decorrentes. $\S 1^{\underline{o}} \mathrm{O}$ indiciado, comparecendo, será interrogado com expressa observância das garantias constitucionais e legais. $\S 2^{\circ} \mathrm{O}$ indiciado será identificado datiloscopicamente nas hipóteses previstas em lei. $\S 3^{0} \mathrm{~A}$ autoridade policial deverá colher informações sobre a vida pregressa do indiciado, sob o ponto de vista individual, familiar e social, sua condição econômica, e outros dados que contribuam para a verificação de sua personalidade. $\S 4^{\mathrm{o}} \mathrm{A}$ autoridade deverá informar ao indiciado a importância do endereço por ele fornecido, para efeito de citação e intimação, bem como sobre o dever de comunicar qualquer mudança de endereço".

Conquanto tenha o projeto em questão o ideal de melhor regulamentar o momento do indiciamento, buscando impedir que o investigado seja ouvido sem assistência da defesa técnica, ou que lhe seja obstaculizado o exercício do direito de defesa, é de se lembrar que a Constituição da República dispõe em seu artigo $5^{\circ}$, inciso LV, que "aos litigantes, em processo judicial ou administrativo, e aos acusados em geral são assegurados o contraditório e a ampla defesa, com os meios e recursos a ela inerentes", o que franqueia o exercício da defesa no inquérito assim que haja uma "acusação em geral", isto é, assim que seja imputado um fato ilícito a alguém, independentemente de ato formal

de Assis Moura, j. 15/05/2008, DJ de 02/06/2008; HC 82494, Rel. Min. Jane Silva (Desembargadora Convocada do TJ/MG), j. 18/10/2007, DJ de 05/11/2007.

${ }^{272}$ Cf. Aury Lopes Jr., Sistemas de investigação..., cit., p. 300.

${ }^{273}$ Cf. Marta Saad Gimenes, op. cit., pp. 173-175. Tal problemática restou evidente quando do julgamento do habeas corpus $\mathrm{n}^{\circ} 84.214$ pelo STF, que em decisão liminar, publicada no Diário de Justiça em 29.05.04, reconheceu o exercício do direito ao silêncio pelo ex-prefeito de São Paulo, Celso Roberto Pitta do Nascimento, chamado a depor na qualidade de testemunha pela Comissão Parlamentar Mista de Inquéritos CPMI do Banestado. Convocado a depor, a qualquer título, o paciente poderia calar-se, exercendo seu direito constitucional ao silêncio sempre que a resposta às perguntas formuladas pudessem trazer-lhe um risco de auto-incriminação. 
nesse sentido ${ }^{274}$, pois, do contrário, a Carta Magna restringiria o exercício da defesa aos "formalmente acusados".

A decisão sobre o momento em que o acusado em geral passará a exercer o direito individual à razoável duração do processo não pode repousar em um juízo discricionário da autoridade policial, a depender do indiciamento que, ademais, acabou por se caracterizar como um ato estigmatizante socialmente e passível de arbitrariedades, em muitos $\operatorname{casos}^{275}$.

Tão logo seja dispensado a um suspeito, objetivamente, um tratamento próprio de imputado, mesmo que ouvido formalmente apenas como testemunha, deve ser considerado iniciado o prazo. Também com a prisão ${ }^{276}$, com o próprio interrogatório policial ou, ainda, com a realização de outras medidas restritivas, tais como busca e apreensão ou interceptação telefônica, fica patente este marco, independentemente de qualquer ato formal.

Esta é, aliás, a proposta do Código Penal Modelo para a Ibero América, que em seu artigo $6^{\circ}$ assim dispõe: “As faculdades que as leis fundamentais do Estado e que este Código outorgam ao imputado, pode fazê-las valer qualquer pessoa a quem se atribua a participação em um fato punível, desde o primeiro ato do procedimento dirigido contra si até a sua finalização. Entender-se-á como primeiro ato do procedimento qualquer indicação que indique uma pessoa como possível autor de um fato punível ou como seu partícipe, ante qualquer autoridade da persecução penal que este Código estabelece”. E, ainda, no artigo 262: “O Ministério Público procurará dar fim ao procedimento preparatório o mais rápido possível, procedendo com a diligência que o caso requeira. Passados seis meses

\footnotetext{
274 “A atribuição da prática de um ato ilícito a determinada pessoa, ainda que de maneira informal, leva a que se tenha acusação e acusado" (Idem, pp. 232/233).

275 A crítica é de Eduardo Reale Ferrari, Código de Processo Penal: comentários aos projetos de reforma legislativa, Campinas, Millenium, 2003, pp. 26-27, que afirma, textualmente: “A nosso ver, o indiciamento constitui uma medida meramente indicativa ao promotor de justiça; a exigir, antes da enunciação sobre sua fundamentação ou não, reflexão sobre sua utilidade processual-penal, já que sequer vinculativo ao Promotor de Justiça, parecendo-nos constituir ato investigativo-administrativo totalmente dispensável em um Estado de Direito Democrático e Social, certo de que arbítrios hoje ultimados por alguns Delegados de Polícia, sob o argumento da ameaça de um indiciamento, poderiam ser evitados, caso suprimido tal ato da novel legislatura, retirando da autoridade policial a formalização de que aquele investigado constitui o provável - e não possível - autor da infração, figurando as provas investigativas muito mais relevantes ao acusador do que o mero etiquetamento do denominado indiciado (...)".

${ }^{276}$ No caso da prisão em flagrante, destaca-se a entrega da nota de culpa ao preso, que caracteriza exatamente essa garantia de notificação da condição de acusado, em sentido amplo, explicitando-se-lhe as imputações que lhe são atribuídas, portanto, as razões de sua prisão.
} 
desde a individualização e comparecimento do imputado, qualquer dos intervenientes poderá requerer ao juiz de instrução a fixação de um prazo para a conclusão da investigação".

\subsubsection{Marco final da contagem do prazo: conclusão da investigação ou decurso do prazo legalmente previsto?}

Embora a investigação criminal se caracterize, em regra, como etapa preparatória para a ação penal e, neste sentido, o momento de sua conclusão não interfira no término do prazo máximo de duração da persecução penal, o fato é que nem sempre ela conduz à formulação de uma acusação ${ }^{277}$, devendo apresentar, portanto, um prazo máximo de duração próprio, para evitar que o indivíduo fique indefinidamente sob suspeita.

O inciso LXXVIII do artigo $5^{\circ}$ da Constituição da República assegura a todos, no âmbito judicial e administrativo, a razoável duração do processo. Engloba, portanto, a razoável duração do procedimento investigativo em si mesmo, para que este não atrase eventual ação penal dele decorrente.

Faz-se necessário, portanto, que a investigação criminal possua um prazo final pré-determinado, podendo-se encontrar exemplos de fixação de prazo para a sua conclusão no Direito Comparado e no Brasil, conforme discorrer-se-á a seguir.

\subsubsection{Itália}

O diploma processual italiano, conquanto preveja um intrincado sistema de prazos, que varia de acordo com o tipo de crime objeto da investigação, tem o mérito de

\footnotetext{
${ }^{277}$ Com o arquivamento, encerra-se a investigação criminal, impedindo o prosseguimento da persecução penal. Ver, ademais, a respeito, Vicente Greco Filho, Manual de Processo Penal, 6 a ed., São Paulo, Saraiva, 1999, p. 92.
} 
fixar prazos razoáveis, mais alargados e condizentes com a realidade ${ }^{278}$ para a conclusão da investigação.

A investigação preliminar na Itália se dá, em regra, dentro de um ano ${ }^{279}$, sendo que o Ministério Público pode requer a prorrogação deste prazo se verificar a impossibilidade de concluir os trabalhos a tempo. Nesse caso, deve fazer um requerimento expondo os motivos que justificam a prorrogação ${ }^{280}$, dando-se a oportunidade para que a defesa fale sobre este pedido ${ }^{281}$.

A possibilidade de prorrogação é, ademais, limitada, podendo ocorrer somente pelo prazo máximo de seis meses ${ }^{282}$.

Portanto, o prazo máximo é, em geral, de dezoito meses, podendo chegar a dois anos, todavia, dependendo do crime investigado ou se este demanda maior tempo de investigação, dada a sua complexidade ${ }^{283}$.

Se o prazo máximo de duração for desrespeitado, os atos da investigação que tiverem sido realizados depois do término do prazo não poderão ser utilizados ${ }^{284}$.

${ }^{278}$ Uma das maiores críticas à observância dos prazos para o término da investigação criminal é a existência
de prazos extremamente curtos e incompatíveis com a realidade complexa de muitas investigações.

279 Artigo 405.2. "Salvo quanto ao disposto no artigo 415-bis, o Ministério Público deve pedir o envio do processo ao juiz dentro de seis meses da data a partir da qual o nome da pessoa a quem é atribuída a autoria é inscrito no registro de notícia de crime. O termo é de um ano se se procede em relação a um dos crimes indicados no artigo 407, II, a".

${ }^{280}$ Artigo 406.1. "O Ministério Público, antes da decadência do prazo, poderá requerer ao juiz, por justa causa, a prorrogação do termo previsto no artigo 405. O pedido indicar a que notícia de crime se refere e a exposição dos motivos que justificam a prorrogação".

${ }^{281}$ Artigo 406.3. "O pedido de prorrogação é notificado, aos cuidados do juiz, com aviso da faculdade de apresentação de memoriais dentro do prazo de cinco dias, à pessoa submetida à investigação e também à vítima que, na notícia do crime ou logo após tenha declarado o desejo de ser informada. O prazo decai em dez dias para a apresentação dos memoriais".

282 Artigo 406.2-bis. "Nenhuma prorrogação pode ser autorizada pelo juiz por um prazo superior a seis meses".

283 Artigo 407.1."Salvo o previsto no artigo 393.4, a duração da investigação preliminar não pode superar dezoito meses. 2. A duração máxima é, todavia, de dois anos se a investigação preliminar se referir a: (...)". No artigo 407.2., são, então, elencadas vinte e quatro hipóteses diferentes, que vão desde a indicação de crimes, como terrorismo, comercialização de armas e tráfico de drogas, até a indicação de situações processuais que justificariam maior delonga no procedimento, como a necessidade de cumprimento de carta rogatória, e crimes que denotam maior complexidade, diante do número de fatos entrelaçados entre si, número de acusado ou de ofendidos.

${ }^{284}$ Art. 407.3. "Salvo o previsto no artigo 415-bis, se o Ministério Público não exercitar a ação penal ou pedir o arquivamento do feito no tempo estabelecido pela lei ou prorrogado pelo juiz, os atos da investigação realizados depois da decadência do prazo, não poderão ser utilizados". 
Tem-se, assim, no ordenamento jurídico italiano, um mecanismo legal de controle de duração da investigação criminal, que não pode ultrapassar o prazo máximo de dois anos em nenhuma hipótese, impondo-se a sanção de innutilizabilità dos elementos de prova colhidos extemporaneamente.

\subsubsection{Portugal}

O artigo 276 do Código de Processo Penal português prevê o prazo de duração de 6 meses para o inquérito contra argüido preso e de 8 meses contra argüido solto, sendo que o prazo de 6 meses pode ser ampliado para 8 meses em alguns tipos de crime $^{285}$, para 10 meses, quando, independentemente do tipo de crime, o procedimento revelar excepcional complexidade ${ }^{286}$, e para 12 meses, se, além de ser um dos crimes elencados no artigo 215,2 , o feito ainda apresentar complexidade ${ }^{287}$.

O controle do prazo é feito pelo Ministério Público, que pode avocar para si o inquérito ${ }^{288}$, ou por meio de um pedido de aceleração, que pode ser deduzido pelo acusado ou pelo ofendido, por meio do assistente ${ }^{289}$, cabendo ao Procurador-Geral da

\footnotetext{
${ }^{285}$ Para os crimes apenas com pena superior a 8 anos de reclusão. É deduzida, ainda, uma lista significativa de crimes tais como terrorismo, criminalidade violenta e organizada, furto de veículos, falsificação de documentos, peculato, falsificação de moeda, lavagem de dinheiro e fraude na obtenção de subsídio, subvenção ou crédito.
}

${ }^{286}$ Artigo 215, 3: "3 - Os prazos referidos no n. ${ }^{\circ} 1$ são elevados, respectivamente, para 12 meses, 16 meses, 3 anos e 4 anos, quando o procedimento for por um dos crimes referidos no número anterior e se revelar de excepcional complexidade, devido, nomeadamente, ao número de arguidos ou de ofendidos ou ao carácter altamente organizado do crime".

287 Artigo 276: “1 - O Ministério Público encerra o inquérito, arquivando-o ou deduzindo acusação, nos prazos máximos de 6 meses, se houver arguidos presos ou sob obrigação de permanência na habitação, ou de 8 meses, se os não houver. 2 - O prazo de 6 meses referido no número anterior é elevado: a) Para 8 meses, quando o inquérito tiver por objecto um dos crimes referidos no artigo $215 .^{\circ},{ }^{\circ}{ }^{\circ}$; b) Para 10 meses, quando, independentemente do tipo de crime, o procedimento se revelar de excepcional complexidade, nos termos do artigo $215^{\circ}$, n. $^{\circ} 3$, parte final; c) Para 12 meses, nos casos referidos no artigo $215 .^{\circ}$, n. $^{\circ} 3^{\prime \prime}$.

288 Artigo 276, 4: "Sempre que tiver conhecimento de que os prazos referidos no número anterior foram excedidos, o Procurador-Geral da República pode mandar avocar o inquérito e procede de acordo com o disposto no artigo 109".

${ }^{289}$ Artigo 108, 1: "Quando tiverem sido excedidos os prazos previstos na lei para a duração de cada fase do processo, podem o Ministério Público, o arguído, o assistente ou as partes civis requerer a aceleração processual. 2 - O pedido é decidido: a) Pelo Procurador-Geral da República, se o processo estiver sob a direcção do Ministério Público; b) Pelo Conselho Superior da Magistratura, se o processo decorrer perante o 
República ou Conselho Superior da Magistratura decidir sobre a extrapolação do prazo, podendo determinar a conclusão do inquérito policial em 15 dias ou tomar as medidas cabíveis para a responsabilização dos agentes estatais, ou para a "organização ou racionalização dos métodos que a situação justificar" ${ }^{290}$.

\subsubsection{França}

No ordenamento francês, o prazo do inquérito é determinado pelo Ministério Público, sendo que, em 6 meses, a autoridade policial deve prestar contas das investigações, cabendo ao promotor decidir se deve, ou não, acatar os pedidos de prorrogação formulados ${ }^{291}$.

\subsubsection{Costa Rica}

tribunal ou o juiz. 3 - Encontram-se impedidos de intervir na deliberação os juízes que, por qualquer forma, tiverem participado no processo".

290 Artigo 109, 1 - O pedido de aceleração processual é dirigido ao presidente do Conselho Superior da Magistratura, ou ao Procurador-Geral da República, conforme os casos, e entregue no tribunal ou entidade a que o processo estiver afecto. 2 - O juiz ou o Ministério Público instruem o pedido com os elementos disponíveis e relevantes para a decisão e remetem o processo assim organizado, em três dias, ao Conselho Superior da Magistratura ou à Procuradoria-Geral da República. 3 - O Procurador-Geral da República profere despacho no prazo de cinco dias. 4 - Se a decisão competir ao Conselho Superior da Magistratura, uma vez distribuído o processo vai à primeira sessão ordinária ou a sessão extraordinária se nisso houver conveniência, e nela o relator faz uma breve exposição, em que conclui por proposta de deliberação. Não há lugar a vistos, mas a deliberação pode ser adiada até dois dias para análise do processo. 5 - A decisão é tomada, sem outras formalidades especiais, no sentido de: a) Indeferir o pedido por falta de fundamento bastante ou por os atrasos verificados se encontrarem justificados; b) Requisitar informações complementares, a serem fornecidas no prazo máximo de cinco dias; c) Mandar proceder a inquérito, em prazo que não pode exceder 15 dias, sobre os atrasos e as condições em que se verificaram, suspendendo a decisão até à realização do inquérito; ou d) Propor ou determinar as medidas disciplinares, de gestão, de organização ou de racionalização de métodos que a situação justificar. 6 - A decisão é notificada ao requerente e imediatamente comunicada ao tribunal ou à entidade que tiver o processo a seu cargo. É-o igualmente às entidades com jurisdição disciplinar sobre os responsáveis por atrasos que se tenham verificado".

${ }^{291}$ Artigo 75, 1. “Ao requisitar a instauração de investigação preliminar, o Ministerio Público fixará um prazo dentro do qual deverá efetuar-se a investigação. Poderá prorrogá-lo em face das justificativas oferecidas pelos investigadores. Quando a investigação for instaurada de ofício, os oficiais da Policía Judiciária darão conta ao promotor acerca do seu estado após transcorridos mais de 6 meses de seu início". 
Na Costa Rica, o Código de Processo Penal não traz um prazo absoluto dentro do qual deve ser concluída a investigação. Todavia, se a investigação começar a apresentar algum tipo de atraso indevido, o imputado pode requerer à autoridade judicial a fixação de um prazo para a conclusão, que pode ser de no máximo seis meses, e que não pode ser ultrapassado sob nenhum fundamento ${ }^{292}$. Nos termos do artigo 171 do Código de Processo Penal da Costa Rica, “O Ministério Público deverá concluir a investigação dentro de um prazo razoável. Quando o imputado estime que o prazo se prolongou indevidamente, solicitará ao tribunal que lhe fixe um termo para que seja finalizada a investigação. O tribunal solicitará um informe ao investigador e, se estimar que houve prolongação indevida segundo a complexidade e dificuldade da investigação, fixará um prazo para que seja concluído, o qual não poderá exceder seis meses"293.

O investigador, ao ser interpelado pelo juiz, faz uma estimativa de quanto tempo levará para concluir a investigação, podendo indicar o prazo que achar necessário, desde que inferior a seis meses. Se o juiz achar que o prazo estimado é razoável, o investigador fica vinculado a este prazo, devendo concluir a investigação dentro dele. Se o juiz achar que a estimativa de prazo não se justifica, poderá fixar prazo menor, vinculando, igualmente, a atividade do investigador ${ }^{294}$.

Na prática, ocorreu que os advogados começaram a pedir a fixação do prazo praticamente desde o início do procedimento, para forçar a sua duração máxima em 6 meses. "Em virtude desse novo instrumento, o defensor do imputado, ou ele mesmo, começaram a solicitar a fixação do prazo em causas que apresentavam algum tipo de atraso e, em alguns casos, solicitou-se a fixação do prazo desde o início do procedimento

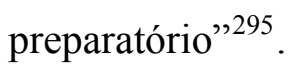

\footnotetext{
${ }^{292}$ Cf. Saul Araya M., "La fijación jurisdicional de plazo pra terminar el procedimiento preparatório: el ser humano no pertence ao proceso; el proceso pertence al ser humano", Revista de Ciências Penales de Costa Rica, ano $15, \mathrm{n}^{\circ} 21$, outubro de 2003 , p. 121.

${ }^{293}$ Art. 171. "O Ministério Público deverá concluir a investigação preparatória em um prazo razoável. Quando o imputado estime que o prazo se prolongou indevidamente, solicitará ao tribunal que fixe um prazo para que seja finalizada a investigação. O tribunal solicitará informações ao investigador e, se estimar que houve prolongação indevida segundo a complexidade e dificuldade da investigação, fixará um prazo para que conclua, o qual não poderá exceder a seis meses".

${ }^{294}$ Saul Araya M., op. cit., p. 124.

${ }^{295}$ Idem, p. 121.
} 


\subsubsection{Brasil}

No sistema brasileiro, embora haja uma previsão legal muito clara e categórica acerca da duração da investigação criminal, o fato é que, por sua escassez - dez dias para réu investigado preso e trinta dias para investigado solto, nos termos do artigo 10 do Código de Processo Penal - os prazos, não raramente, são desrespeitados na prática ${ }^{296}$.

Há previsão legal de prorrogação de tais prazos apenas quando se tratar de "fato de difícil elucidação", e somente na hipótese em que o investigado esteja solto, nos termos do $\S 3^{\circ}$ do artigo 10 do Código de Processo Penal, que assim dispõe, verbis: "Quando o fato for de difícil elucidação, e o indiciado estiver solto, a autoridade poderá requerer ao juiz a devolução dos autos, para ulteriores diligências, que serão realizadas no prazo marcado pelo juiz".

Assim, em princípio, o prazo de duração do inquérito relativamente ao investigado preso deveria ser improrrogável, impondo-se, se fosse o caso, diante da necessidade de novas diligências, a sua imediata soltura, por dedução lógica do mencionado dispositivo ${ }^{297}$. Todavia, podem ser encontrados diversos julgados em que é admitida a prorrogação do prazo da investigação, mesmo com relação ao investigado preso, com fundamento no princípio da razoabilidade ${ }^{298}$.

\footnotetext{
${ }^{296}$ De acordo com Rogério Lauria Tucci, "essa norma legal [artigo 10 do Código de Processo Penal] é, correntemente, inobservada, prolongando-se a atividade investigatória por tempo indefinido, numa sucessão de prorrogações, de todo inadmissíveis" (Direitos e garantias..., op. cit., p. 258).

${ }^{297}$ Muitos são os julgados, mormente os mais antigos, sustentando a necessidade de soltura do investigado se extrapolado o prazo para a conclusão do inquérito: STF, RHC 41.974, Tribunal Pleno, Rel. Min. Gonçalves de Oliveira, j. 02/06/1965 ("O prazo de 10 dias para remessa dos autos de flagrante a juízo é fatal. Excedido, concede-se o habeas corpus); STF, RHC 48.675, Primeira Turma, Rel. Min. Barros Monteiro, j. 09/03/1971 ("Se a lei prefixa o prazo de dez dias para a conclusão do inquérito em caso do indiciado encontrar-se preso, é induvidoso que, dentro daquele prazo, as investigações policiais deverão dar entrada na Justiça Criminal"); TACrim-SP, RHC 19.268, $3^{\text {a }}$ Câmara, Rel. Juiz Prestes Barra, j. 19/02/1970 (Não é possível exigir-se a entrega do inquérito antes do $11^{\circ}$ dia da prisão em flagrante do indiciado, sob pena de restringir-se o prazo legal de 10 dias; mas, no dia seguinte, ele há de ser distribuído ou remetido ao juízo competente, sob pena de constrangimento ilegal"); TJSP, HC 84.677, Câmara Criminal, Rel. Des. Cantidiano de Almeida, j. 14/09/1965 ("É de dez dias o prazo para o término do inquérito e sua remessa a juízo, em se tratando de réu preso. Trata-se de prazo fatal que, excedido, dá margem à concessão de habeas corpus”).

${ }^{298}$ Conferir, nesse sentido, dentre outros: TDFT, HC 20080020119751, Segunda Turma, Rel. Maria Ivatônia, j. 18/09/2008, DJ de 03/10/2008; TJDFT, HC 20080020072919, Segunda Turma, Rel. João Mariosa, j. 24/07/2008, DJ de 10/09/2008; TJDFT, HC 20080020014847, Primeira Turma, Rel. Sandra de Santis, j. 06/03/2008, DJ de 16/06/2008 (“Ademais, imprescindível raciocinar com o juízo da razoabilidade para definir o excesso de prazo. A complexidade da conclusão dos inquéritos policias e a dificuldade da instrução criminal autorizam a dilação do prazo, que não pode resultar de mera soma aritmética").
} 
É de se destacar, ainda, relativamente ao prazo de duração do inquérito policial com investigado preso, a existência de uma quebra de coerência no sistema quando se trata de imposição de prisão temporária. Originalmente, nos termos do artigo $2^{\circ}$ da Lei 7.960/89, a prisão temporária tinha o prazo máximo de 5 dias, prorrogáveis por mais cinco, coincidindo com o prazo total de 10 dias previsto no artigo 10 do Código de Processo Penal para a duração do inquérito em que o investigado estivesse preso. Todavia, com a Lei dos Crimes Hediondos, a duração para a prisão temporária aplicada para a apuração deste tipo de crime passou a ser de 30 dias, prorrogáveis por mais trinta dias, totalizando sessenta dias, prazo que excede, em muito, o total máximo de duração do inquérito. Como bem observado por DELMANTO JR., criou-se um tratamento desigual para o preso preventivamente pela mesma espécie de crimes, para quem o inquérito deverá durar no máximo 10 dias e o preso temporariamente, que poderia, em tese, ficar preso por 60 dias, sendo que a prisão preventiva depende, para sua decretação, de um grau maior de cautelaridade do que o necessário para a prisão temporária, não se havendo como aplicarse o prazo de 60 dias trazido pela Lei 8.072/90 299 .

Com relação ao investigado solto, mostra-se relativamente pacífico na jurisprudência brasileira o entendimento de que inexiste qualquer constrangimento ilegal na prolongação da investigação, apesar de existir prazo legal para o término do inquérito policial também nessa hipótese ${ }^{300}$. A ausência de limite quantitativo para a prorrogação do prazo acaba abrindo espaço a reiterados pedidos de prorrogação, fazendo com que o inquérito se estenda muito além dos 30 dias inicialmente previstos.

A decisão de prorrogação por parte do juiz, em qualquer caso, deve ser devidamente fundamentada - como de resto devem ser motivadas todas as decisões, por

\footnotetext{
${ }^{299}$ Roberto Delmanto Júnior, As modalidades de prisão preventiva e seu prazo de duração, Rio de Janeiro, Renovar, 1998, p. 223.

300 Cf., nesse sentido, STJ, Sexta Turma, RHC 1784/SP, Rel. Min. José Cândido de Carvalho Filho, j. 11/05/1992, DJ de 01/06/1992. Mais recente, e em idêntico posicionamento, ver: STJ, Quinta Turma, HC 44649, Rel. Min. Laurita Vaz, j. 11/09/2007, DJ de 08/10/2007, em que se consignou que "não obstante o considerável lapso de tempo decorrido desde a instauração do inquérito policial, nenhum constrangimento ilegal por excesso de prazo para sua conclusão se evidencia na espécie, não apenas porque não demonstrada nenhuma desídia na condução da investigação, mas também tendo em conta que a paciente se encontra em liberdade, não sofrendo qualquer constrição em sua liberdade de locomoção". Em caso recente, a Quinta Câmara do Superior Tribunal de Justiça determinou, em sentido contrário, o trancamento de inquérito policial que se arrastava por mais de sete anos sem que tivesse sido oferecida denúncia contra o investigado solto, ao fundamento de que "não se pode admitir que alguém seja objeto de investigação eterna, porque essa situação, por si só, enseja evidente constrangimento, abalo moral, e, muitas vezes, econômico e financeiro" (STJ, Quinta Turma, HC 96.666-MA, Rel. Min. Napoleão Nunes Maia Filho, j. 04/09/2008).
} 
força do artigo 93, inciso IX, da Constituição da República - , em especial porque se está a falar de decisão que importa em restrição a direitos fundamentais ${ }^{301}$. Não há espaço, portanto, a qualquer sistema de prorrogação automática.

CHOUKR defende a possibilidade desta praxis forense de reiterada prorrogação dos prazos entendendo que "muito embora tenha o legislador procurado delimitar temporalmente o trâmite da investigação, não soube fazê-lo, criando um artigo superficialmente rigoroso, mas praticamente inoperante, além de tecnicamente imperfeito" 302 .

Com efeito, os prazos previstos em lei para a conclusão do inquérito policial são bastante exíguos, o que pode trazer alguns problemas práticos, de acordo com AURY LOPES JR.: "Se realmente se quer um instrumento sério, esse prazo não pode ser excessivamente exíguo (como no inquérito) porque isso leva a dois problemas: a) o mero descumprimento, como sói ocorrer, gerando o mais completo descrédito da norma; b) ou, o que é pior, leva a conclusões equivocadas e processos imaturos e infundados, simplesmente por utilitarismo judicial ( e policial) ou para dar uma satisfação à imprensa e à opinião pública"303. É claro que é possível que a investigação se dê de forma célere e mesmo assim bem conduzida, dentro dos prazos legais, e é isto que se espera da Polícia Judiciária, mas a chance de que isso ocorra, com tantos crimes sendo investigados ao mesmo tempo, diminui sensivelmente com a previsão de prazos tão reduzidos.

Todavia, sendo os prazos muito escassos ou impraticáveis, a questão deve repousar no âmbito legislativo, cobrando-se a edição ou a reforma dos prazos já existentes para que se adaptem à realidade social atual. Como bem ressaltado por TUCCI, a lei existe para ser cumprida, não valendo o argumento de que é normal essa constante sucessão de prorrogações, a despeito de expressa determinação legal ${ }^{304}$.

\footnotetext{
${ }^{301}$ Lapidar é o ensinamento de Antonio Magalhães Gomes Filho a este respeito: "Na verdade, à proeminência dos direitos fundamentais corresponde um dever ainda mais concreto de justificar os provimentos judiciais que possam limitá-los, até porque nos ordenamentos modernos a forma típica, embora não exclusiva de garantia é a jurisdicional; é ao Judiciário que incumbe o controle último da própria constitucionalidade de restrições admitidas pelo legislador. (...) Ressalta-se, assim, no próprio contexto dos direitos fundamentais a magnitude do dever de fundamentação como garantia política da legitimidade da intervenção estatal quando se trata de restringir a liberdade individual" (A motivação das decisões penais, São Paulo, Revista dos Tribunais, 2001, pp. 93-94).

${ }^{302}$ Fauzi Hassan Choukr, op. cit., p. 159.

${ }^{303}$ Aury Lopes Jr., Sistemas de investigação..., p. 272.

${ }^{304}$ Rogério Lauria Tucci, Direitos e garantias..., cit., p. 259.
} 
No Código de Processo Penal Militar há, por exemplo, a previsão de prazos máximos para o término do inquérito policial, um pouco mais extensos do que os previstos para os crime comuns, sendo de 20 dias para o indiciado preso e 40 dias para o indiciado solto $^{305}$.

Ademais, a disciplina processual castrense se destaca por trazer maior detalhamento acerca da possibilidade de prorrogação desse prazo, limitando a prorrogação da seguinte maneira: (i) a prorrogação deverá ser requerida antes do término do prazo previsto no caput do artigo $20 ;^{306}$ (ii) o pedido de prorrogação deverá se fundar em alguma das hipóteses pré-determinadas: se não estiverem concluídos exames e perícias já iniciados e se houver necessidade de diligência indispensável à elucidação do fato $^{307}$; (iii) a prorrogação deverá ser de 20 dias, se autorizada ${ }^{308}$; (iv) a prorrogação é cabível por uma única vez, salvo "dificuldade insuperável”, a juízo do Ministro de Estado competente ${ }^{309}$.

Esgotado o período de prorrogação, há a previsão de que os resultados dos laudos e perícias que se iniciaram, mas que não puderam ser concluídos no prazo do inquérito, assim como os documentos colhidos depois, poderão ser remetidos ao juiz, para a juntada no processo. $\mathrm{O}$ encarregado do inquérito ${ }^{310}$ deverá indicar, ainda, no seu relatório

\footnotetext{
${ }^{305}$ Conforme o artigo 20: "O inquérito deverá terminar dentro em vinte dias, se o indiciado estiver preso, contado esse prazo a partir do dia em que se executar a ordem de prisão; ou no prazo de quarenta dias, quando o indiciado estiver solto, contados a partir da data em que se instaurar o inquérito".
}

${ }^{306}$ Cf. artigo 20, $\S 1^{\circ}$, parte final: “(...) O pedido de prorrogação deve ser feito em tempo oportuno, de modo a ser atendido antes da terminação do prazo".

${ }^{307}$ Cf. artigo 20, $\S 1^{\circ}$, primeira parte: "Este último prazo poderá ser prorrogado por mais vinte dias pela autoridade militar superior, desde que não estejam concluídos exames ou perícias já iniciados, ou haja necessidade de diligência, indispensáveis à elucidação do fato (...)".

${ }^{308}$ Idem.

309 Cf. artigo 20, $\S 2^{\circ}$, primeira parte: "Não haverá mais prorrogação, além da prevista no $\S 1^{\circ}$, salvo dificuldade insuperável, a juízo do ministro de Estado competente (...)".

${ }^{310}$ A determinação do encarregado do inquérito policial militar é feita conforme as seguintes regras do Código de Processo Penal Militar: “Art. $7^{\circ}$ A polícia judiciária militar é exercida nos termos do art. $8^{\circ}$, pelas seguintes autoridades, conforme as respectivas jurisdições:

a) pelos ministros da Marinha, do Exército e da Aeronáutica, em todo o território nacional e fora dele, em relação às forças e órgãos que constituem seus Ministérios, bem como a militares que, neste caráter, desempenhem missão oficial, permanente ou transitória, em país estrangeiro;

b) pelo chefe do Estado-Maior das Forças Armadas, em relação a entidades que, por disposição legal, estejam sob sua jurisdição;

c) pelos chefes de Estado-Maior e pelo secretário-geral da Marinha, nos órgãos, forças e unidades que lhes são subordinados;

d) pelos comandantes de Exército e pelo comandante-chefe da Esquadra, nos órgãos, forças e unidades compreendidos no âmbito da respectiva ação de comando; 
final, as testemunhas que, por qualquer impedimento, deixaram de ser ouvidas na fase preliminar e o endereço onde poderão ser encontradas ${ }^{311}$.

No projeto de Lei 4.209/2001 ${ }^{312}$, ainda em trâmite legislativo, manteve-se o prazo de 10 dias para a conclusão do inquérito estando o indiciado preso, ampliando-se, todavia, para 60 dias o prazo se este estiver solto, portanto, o dobro do prazo atual. Além do que, de acordo com a proposta legislativa, o inquérito policial se torna bem menos formal, o que também colabora para que a investigação seja concluída em menor tempo.

\subsection{Garantia do término da ação penal dentro de um prazo razoável}

\subsubsection{Tribunal Europeu de Direitos Humanos}

e) pelos comandantes de Região Militar, Distrito Naval ou Zona Aérea, nos órgãos e unidades dos respectivos territórios;

f) pelo secretário do Ministério do Exército e pelo chefe de Gabinete do Ministério da Aeronáutica, nos órgãos e serviços que lhes são subordinados;

g) pelos diretores e chefes de órgãos, repartições, estabelecimentos ou serviços previstos nas leis de organização básica da Marinha, do Exército e da Aeronáutica;

h) pelos comandantes de forças, unidades ou navios. $\S 1^{\circ}$ Obedecidas as normas regulamentares de jurisdição, hierarquia e comando, as atribuições enumeradas neste artigo poderão ser delegadas a oficiais da ativa, para fins especificados e por tempo limitado.

$\S 2^{\circ}$ Em se tratando de delegação para instauração de inquérito policial militar, deverá aquela recair em oficial de posto superior ao do indiciado, seja este oficial da ativa, da reserva, remunerada ou não, ou reformado.

$\S 3^{\circ}$ Não sendo possível a designação de oficial de posto superior ao do indiciado, poderá ser feita a de oficial do mesmo posto, desde que mais antigo.

$\S 4^{\circ}$ Se o indiciado é oficial da reserva ou reformado, não prevalece, para a delegação, a antiguidade de posto".

${ }^{311}$ Cf. artigo 20, §2º parte final: “(...) Os laudos de perícias ou exames não concluídos nessa prorrogação, bem como os documentos colhidos depois dela, serão posteriormente remetidos ao juiz, para a juntada ao processo. Ainda, no seu relatório, poderá o encarregado do inquérito indicar, mencionando, se possível, o lugar onde se encontram as testemunhas que deixaram de ser ouvidas, por qualquer impedimento".

312 O Projeto de Lei $\mathrm{n}^{\mathrm{o}}$ 4.209/2001 faz parte de um conjunto de Projetos de Lei apresentados por uma Comissão de Reforma presidida pela Prof ${ }^{a}$ Ada Pellegrini Grinover, sendo que de oito projetos, restam apenas três a serem aprovados, dentre eles o projeto em questão, relativo ao inquérito policial, que é o que encontra mais obstáculos políticos à provação. A redação proposta para o artigo 10 do Código de Processo Penal é a seguinte: "Artigo 10. O inquérito policial, em qualquer caso, deverá ser concluído no prazo de sessenta dias, contados do conhecimento da infração penal pela autoridade policial, salvo se o indiciado estiver preso, quando o prazo será de 10 dias. $\S 1^{\circ}$. Excedido qualquer dos prazos assinados à polícia judiciária, o ofendido poderá recorrer à autoridade policial superior ou representar ao Ministério Público, objetivando a finalização do inquérito e a determinação da responsabilidade da autoridade e de seus agentes". 
Num dos primeiros casos tratados pelo Tribunal Europeu de Direitos Humanos, o caso Wemhoff, julgado em 27 de junho de 1968, não houve um esclarecimento, por parte daquela Corte, quanto ao marco final do prazo razoável, estabelecendo-se apenas que este deveria se estender "pelo menos" até a decisão de primeira instância, sem que se especificasse se deveria ser levado em consideração o tempo gasto com os recursos posteriores até a decisão final de mérito ${ }^{313}$.

Posteriormente, no caso Ringeisen, julgado em 17 de julho de 1971, a questão veio novamente à tona. O governo austríaco alegava que não havia que se cogitar em violação da garantia da razoável duração do processo após a prolação de uma sentença de mérito em primeira instância. O Tribunal Europeu rechaçou o argumento austríaco, reconhecendo o excesso de prazo da prisão mesmo após a prolação da sentença, mas não chegou a especificar até onde alcançava a garantia da razoável duração do processo.

Nesse mesmo caso, relevante registrar que houve um voto vencido, proferido pelo juiz Zekia, para quem, após uma sentença condenatória de primeira instância, não prevalece o princípio da presunção de inocência, não se podendo alegar excesso de prazo da prisão, que já não apresenta mais um caráter cautelar. Importante, a esse respeito, como bem ressaltado por PASTOR, que o juiz Zekia sofreu grande influência do ordenamento jurídico de seu país, em que todos os crimes são julgados por jurados, e nos quais se atribui muito maior importância ao seu veredicto, abrindo-se espaço à chamada execução provisória da pena, rechaçada em outros sistemas jurídicos ${ }^{314}$.

No julgamento do caso Eckle, em 15 de julho de 1982, o entendimento do Tribunal Europeu passou a se tornar mais claro, consignando agora que, para a aferição do "prazo razoável em matéria penal", deve-se entender como abrangido o período total do procedimento em exame, incluindo os "procedimentos de apelação"315.

Finalmente, no caso Foti e outros, sentenciado em 10 de dezembro de 1982, o Tribunal esclareceu, de uma vez por todas, o entendimento daquele órgão, prescrevendo,

\footnotetext{
${ }^{313}$ Daniel R. Pastor, El plazo razonable..., cit., p. 115.

${ }^{314}$ Idem, p. 135.

${ }^{315}$ Idem, p. 146.
} 
de modo bastante claro, que o marco final para a consideração do prazo de duração do processo é "o dia em que a solução definitiva cobrou força de coisa julgada"316.

Para não deixar dúvidas, o Tribunal terminou por ratificar o mesmo entendimento, que privilegia o trânsito em julgado da sentença de mérito, especificando ainda, no caso Deumeland, de 29 de maio de 1986, que o prazo deve incluir todos os recursos, inclusive os recursos extraordinários ${ }^{317}$.

\subsubsection{Corte Interamericana de Direitos Humanos}

A Corte Interamericana de Direitos Humanos, seguindo, mais uma vez, a orientação adotada pela Corte européia, fixou o entendimento de que "o processo termina quando se prolata sentença definitiva e firme a respeito do assunto e, particularmente em matéria penal, o prazo razoável deve compreender todo o procedimento, incluindo os recursos que eventualmente possam ser interpostos" 318 .

No caso Tibi versus Equador, a Corte Interamericana voltou a considerar que "o processo se conclui quando se prolata sentença definitiva e firme a respeito do assunto, com a qual se esgota a jurisdição, e que, particularmente em matéria penal, este prazo deve compreender todo o procedimento, incluindo os recursos que eventualmente possam ser interpostos" ${ }^{\prime 319}$.

O mesmo entendimento foi diversas outras vezes reforçado, como em $1^{\circ}$ de fevereiro de 2006, no caso López Alvarez versus Honduras e Jaramillo e outros versus Colômbia.

No caso Caesar versus Trinidad y Tobago, de 11 de março de 2005, chegouse considerar que, apesar de concluído o processo penal, deve haver prazo razoável para a aplicação da pena imposta em sede de execução.

\footnotetext{
${ }^{316}$ Idem, p. 154.

${ }^{317}$ Idem, p. 160.

${ }^{318}$ Caso Comerciantes versus Colômbia, julgado em 5 de julho de 2004.

${ }^{319}$ Sentença de 7 de setembro de 2004.
} 


\subsubsection{Brasil}

O marco ideal para o término da contagem do prazo razoável de duração do processo, na esteira do que vem sendo decidido pelos tribunais internacionais, é a decisão de mérito irrecorrível, ou seja, aquela acobertada pelo trânsito em julgado. No processo penal brasileiro, "o entendimento não poderá ser distinto: o termo final do direito ao julgamento no prazo razoável (CR, art. $5^{\circ}$, inc. LXXVIII) é o trânsito em julgado" 320 .

O processo criminal há de se mostrar razoável em sua duração, do começo ao fim. Ocorre que a persecução penal possui três fases distintas, a fase das investigações preliminares, a fase do juízo de primeiro grau, e a fase recursal ${ }^{321}$, cada uma delas necessitando de um prazo máximo de duração demarcando o seu término. Isto se justifica pelo fato de que um processo não necessariamente chegará até a fase recursal, necessitando, assim, de delimitação temporal adequada para cada um destes intervalos. Assim, passar-se-á a estudar a forma como incide a garantia da razoável duração do processo nestas duas fases da persecução penal.

\subsubsection{Fase do juízo de primeiro grau}

Existem duas situações distintas que precisam restar bem delimitadas no âmbito deste trabalho: o direito a ser posto em liberdade, em razão do excesso de prazo para a prisão cautelar (prazo razoável para a prisão) e o direito a ser julgado em prazo razoável (prazo razoável para o término do processo).

Nesse sentido, ressalte-se a lição de AURY LOPES JR. e GUSTAVO BADARÓ a respeito: "Registre-se, novamente, que o critério da razoabilidade aparece sempre duplamente considerado: como elemento de justiça inerente ao devido processo legal, aplicável a processos penais ou não penais $\left(\mathrm{CADH}\right.$, art. 8.1; $\mathrm{CEDH}$, art. $\left.6, \S 1^{\circ}\right)$ e também como prazo de julgamento do indivíduo encarcerado preventivamente, sob pena

\footnotetext{
${ }^{320}$ Cf. Aury Lopes Jr. e Gustavo Henrique Righi Ivahy Badaró, op. cit., p. 95.

${ }^{321}$ Idem, p. 84.
} 
de este ser posto em liberdade durante a instrução $\left(\mathrm{CADH}\right.$, art. $7.5 ; \mathrm{CEDH}$, art. $5^{\circ}$, $\left.\$ 3^{\circ}\right)^{, 322}$.

Diante da ausência de prazo de duração máxima tanto para a prisão cautelar quanto para o processo, os esforços do Poder Judiciário acabaram se concentrando mais no sentido de evitar o excesso de prazo da prisão ${ }^{323}$, situação em que existe maior restrição aos direitos do acusado. "Não tem sido tarefa fácil, com efeito, determinar qual o período máximo de tempo dentro do qual deveria estar definitivamente encerrado o procedimento criminal com o acusado detido provisoriamente, sem que houvesse grave ofensa ao princípio da presunção de inocência"324.

A necessidade de delimitar temporalmente o prazo de duração da prisão cautelar e, principalmente, a existência de norma no diploma processual penal considerando constrangimento ilegal, sanável via habeas corpus, a hipótese de alguém "preso por mais tempo do que determina a lei" (artigo 648, II, do Código de Processo Penal), conduziu à criação de critério jurisprudencial consistente na soma dos prazos legalmente previstos para cada ato do procedimento, chegando-se a um quantum a partir do qual, na ausência de qualquer outro limite para a prisão provisória, deveria ser considerado para fins desencarceramento do acusado.

Este critério jurisprudencial ficou conhecido como "jurisprudência dos 81 dias", por causa da soma resultante dos atos do procedimento ordinário, contados de acordo com a antiga redação do Código de Processo Penal. Para chegar-se à soma de 81 dias, referente ao antigo procedimento ordinário perante a Justiça Estadual, calculou-se o prazo da seguinte maneira: 10 dias para a conclusão do inquérito policial (artigo 10 do Código de Processo Penal) + 5 dias para o oferecimento da denúncia (artigo 46 do Código de Processo Penal) + 3 dias para a defesa prévia (artigo 395 do Código de Processo Penal) + 20 dias para a oitiva das testemunhas da acusação (artigo 401 do Código de Processo Penal) + 2 dias para os pedidos de diligências (artigo 499 do Código de Processo Penal) + 10 dias para o despacho do art. 499 (artigo 499 c/c artigo 800, II, e $§ 3^{\circ}$, ambos do Código de Processo Penal) + 6 dias para as razões finais (artigo 500 do Código de Processo Penal)

\footnotetext{
${ }^{322}$ Idem, ibidem.

323 "Não tem havido, contudo, maior preocupação no sistema processual penal com tal garantia [da razoável duração do processo], exceto no que tange ao tempo de prisão" (Antonio Scarance Fernandes, Processo Penal..., cit., p. 119).

${ }^{324}$ Antonio Magalhães Gomes Filho, Presunção de inocência e prisão cautelar, $1^{\text {a }}$ ed., São Paulo, Editora Saraiva, 19991, p. 73.
} 
+ 5 dias para as diligências de ofício (artigo 502, caput, do Código de Processo Penal) + 10 dias para a prolação de sentença (artigo 800 , I e $\$ 3^{\circ}$, do Código de Processo Penal) $=81$ dias, no mínimo, para a realização do procedimento.

Esta soma de 81 dias sofre alterações dependendo do procedimento adotado. No procedimento sumário, no procedimento do tribunal do júri ou em procedimentos especiais (por exemplo, da Justiça Federal, Lei de Drogas, etc.), a soma dos prazos previstos para cada ato processual integrante do procedimento resulta num valor distinto, mas em todos os casos o parâmetro seguido é o mesmo.

Trata-se, portanto, de medida apenas paliativa, porém inspirada numa louvável homenagem à liberdade ${ }^{325}$. O recomendável seria que houvesse a previsão de prazo legal de duração da prisão, pois “em matéria de prisão cautelar, não há falar-se em prazos judiciais (fixados pelo juiz), mas somente em prazos legais (fixados pela lei)" ${ }^{\text {,26. }}$. De qualquer modo, ausente qualquer limite máximo legal, a iniciativa judicial mostrou-se bastante elogiável em se tratando de réu preso.

Antes mesmo da Constituição de 1988, quando ainda não se falava em presunção de inocência, senão por meio dos influxos trazidos por documentos internacionais de direitos humanos, acabou-se por optar por uma idéia que respeita completamente a lógica do sistema e ainda privilegia o princípio da legalidade, somandose os únicos prazos existentes em lei, de duração do próprio procedimento, ainda que, como já afirmado, não reflitam a realidade de todos os casos em concreto, para encontrar um máximo "tolerável” de tempo para a prisão.

Com relação ao acusado preso, existia, portanto, um prazo de duração do processo perante o juízo de primeiro grau, que, se desrespeitado, conduzia à sua soltura.

Ocorre que, paulatinamente, o marco final dessa contagem foi sendo alterado no âmbito da jurisprudência. Mantendo-se o mesmo prazo de 81 dias, cuja soma incluía os prazos necessários até para a prolação da sentença, fixou-se o entendimento de

\footnotetext{
325 "Diante dessas dificuldades em sistemas até mais avançados em termos de garantias processuais, não é ousado afirmar que a orientação consagrada pela jurisprudência nacional tem sido exemplar, no sentido do respeito ao direito de liberdade do réu ainda não condenado, no que toca à celeridade processual" (Antonio Magalhães Gomes Filho, Presunção de inocência..., cit., p. 74).

${ }^{326}$ Roberto Delmanto Junior, As modalidades de prisão provisória..., cit., p. 213.
} 
que, uma vez encerrada a instrução criminal, ficaria superada a alegação de constrangimento ilegal por excesso de prazo $^{327}$.

Tal é o entendimento que restou cristalizado na Súmula $\mathrm{n}^{\circ} 52$ do Superior Tribunal de Justiça, publicada em 24 de setembro de $1992^{328}$. Da análise dos precedentes que conduziram à edição da referida Súmula, não fica claro em nenhum deles o que motivou a alteração do entendimento até então adotado, de que a contagem dos 81 dias deveria alcançar a prolação da sentença. Apenas passou-se a considerar que encerrada a instrução, fica superado o excesso de prazo. No habeas corpus $\mathrm{n}^{\mathrm{o}} 213^{329}$ e no recurso em

327 "O encurtamento do termo final, ou seja, a adoção de um termo ad quem anterior ao julgamento em primeiro grau, é incompatível com o direito ao processo penal em prazo razoável, assegurado pelo art. $5^{\circ}$, inciso LXXVIII, da CR. O direito à 'razoável duração do processo' não pode ser reduzido ao direito à 'razoável duração da instrução'. O término da instrução não põe fim ao processo! Encerrada a instrução, isto é, concluída a oitiva das testemunhas de defesa, ainda restará a fase do art. 499, a eventual realização de diligências complementares deferidas pelo juiz, as alegações finais das partes, as eventuais diligências determinadas ex ofício pelo juiz e, finalmente, o prazo para sentença. Os prazos para a prática de todos estes atos foram computados para que se chegasse ao prazo global dos 81 dias" (Gustavo Henrique Righi Ivahy Badaró, op. cit., pp. 33-34).

${ }^{328}$ Inúmeros são os julgados em que o entendimento da Súmula $\mathrm{n}^{\circ} 52$ do Superior Tribunal de Justiça é aplicado: TJRJ, HC 2008.059.07861, Primeira Câmara, Rel. Des. Ricardo Bustamante, j. 27/11/2008; TJRJ, HC 2008.059.07723, Primeira Turma, Rel. Des. Moacir Pessoa de Araújo, j. 13/11/2008; TJRJ, HC 2008.059.07257, Quarta Câmara, Rel. Des. Gizelda Leitão, j. 04/11/2008; TJRJ, HC 2008.059.07257, Quarta Câmara, Rel. Des. Gizelda Leitão Teixeira, j. 04/11/2008; TJRJ, HC 2008.059.07111, Primeira Câmara, Rel. Des. Ricardo Bustamante, j. 22/10/2008; TRF 3 ${ }^{a}$ Região, HC 2008.03.00.017146-0, Quinta Turma, Rel. Juíza

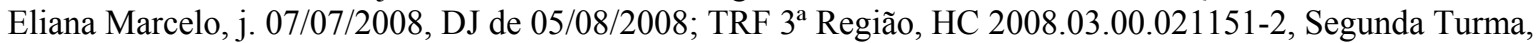
Rel. Juíza Cecília Mello, j. 09/09/2008, DJ de 25/09/2008; TRF 3ª Região, HC 2006.03.00.035964-6, Quinta Turma, Rel. Juíza Ramza Tartuce, j. 17/07/2006, DJ de 22/08/2006; TRF 4ª Região, HC 2008.04.00.0299971, Sétima Turma, Rel. Néfi Cordeiro, j. 09/09/2008, DJ de 17/09/2008; TRF 4 a Região, HC 2007.04.00.040979-6, Oitava Turma, Rel. Des. Luiz Fernando Wowk Penteado, j. 16/01/2008, DJ de 23/01/2008; TRF 4a Região, HC 2006.04.00.020396-0, Sétima Turma, Rel. Décio José da Silva, j. 01/08/2006, DJ de 23/08/2006; TRF 4 Ra Região, HC 2006.04.00.000361-1, Sétima Turma, Rel. Néfi Cordeiro; TRF $1^{\text {a }}$ Região, HC 2005.01.00.057661-9, Quarta Turma, Rel. Des. Fed. Carlos Olavo, j. 27/09/2005, DJ de 28/10/2005; TRF $1^{a}$ Região, HC 2004.01.00.056929-8, Turma Especial de Férias, Rel. Des. Fed. Olindo Menezes, j. 24/01/2005, DJ de 11/02/2005; TRF $1^{\text {a }}$ Região, HC 2008.01.00.026678-0, Quarta Turma, Rel. Des Fed. Mário César Ribeiro, j. 12/08/2008, DJ de 02/09/2008; TRF $1^{a}$ Região, HC 2008.01.00.013914-2, Quarta Turma, Rel. Juíza Federal Rosimayre Gonçalves de Carvalho, j. 24/06/2008, DJ de 25/07/2008; TRF $1^{a}$ Região, HC 2008.01.00.012340-4, Quarta Turma, Rel. Des Fed. Mário César Ribeiro, j. 19/05/2008, DJ de 25/07/2008; TRF $1^{\text {a }}$ Região, HC 2007.01.00.058368-7, Terceira Turma, Rel. Juiz Federal Evaldo de Oliveira Fernandes, j. 21/01/2008, DJ de 01/02/2008; TJMG, HC 1.0000.08.480341-0, Rel. Pedro Vergara, j. 23/09/2008, DJ de 27/10/2008; TJMG, HC 1.0000.08.479858-6, Rel. Hélcio Valentim, j. 16/09/2008, DJ de 29/09/2008; TJMG, HC 1.0000.07.460249-1, Rel. Vieira de Brito, j. 09/10/2007, DJ de 20/10/2007; TJMG, HC 1.0000.04.412455-0, Rel. Gudesteu Biber, j. 28/09/2004, DJ de 01/10/2004; TJMG, HC 1.0000.04.411743-0, Rel. Célio César Paduani, j. 26/08/2004, DJ de 14/09/2004; TJMG, HC 1.0000.04.411644-0, Rel. Sérgio Braga, j. 17/08/2004, DJ de 24/08/2004; TJSP, HC 990081172348, $13^{\text {a }}$ Câmara, Rel. Lopes Silva, j. 04/12/2008, DJ de 12/01/2009; TJSP, HC 990081620987, 6 a Câmara, Rel. José Raul Gavião de Almeida, j. 27/11/2008, DJ de 18/12/2008; TJRS, HC 70027736164, Rel. José Antônio Hirt Preiss, j. 18/12/2008, DJ de 05/01/2009.

${ }^{329}$ STJ, HC 213, Quinta Turma, Rel. Min. Jesus Costa Lima, j. 16/04/1990, DJ de 20/08/1990. 
habeas corpus $\mathrm{n}^{\mathrm{o}} 1081^{330}$, julgados pelo Superior Tribunal de Justiça, já havia sido prolatada a sentença, o que prejudicou a análise referente ao excesso de prazo. No recurso em habeas corpus $n^{\circ} 834$, o excesso de prazo foi afastado sob o argumento de que "a esta altura já se encontra concluída a instrução e, quiçá, proferida sentença no respectivo processo" 331 . A partir daí, nos precedentes subseqüentes ${ }^{332}$, passou-se a reproduzir a idéia de que, encerrada a instrução, ficava afastada a alegação de excesso de prazo, o que talvez representaria um indicativo de que a tônica destas decisões estava na iminência da prolação da sentença, que levaria à prejudicialidade do pedido.

No mais antigo deles, o recurso em habeas corpus $\mathrm{n}^{\circ} 239$, de 1989 , o argumento central para considerar afastada a alegação de excesso de prazo para a prisão após encerrada a instrução criminal repousou na gravidade do crime e na periculosidade demonstrada pelo agente, fatores a indicar a necessidade de manter-se a prisão para garantia da ordem pública ${ }^{333}$.

$\mathrm{Na}$ opinião de BADARÓ, a Súmula $\mathrm{n}^{\circ} 52$ representou uma preocupação com a exigüidade do prazo de 81 dias, que se mostrava insuficiente na prática. Para ele, "A súmula $\mathrm{n}^{\circ} 52$ é fruto da conjugação de dois fatores: o primeiro deles é a constatação de que os 81 dias para o término do procedimento ordinário, isto é, para a prolação da sentença de $1^{\mathrm{o}}$ grau, vinha se mostrando uma meta dificilmente atingível; o segundo fator é uma postura reacionária ao entendimento de que se o processo de réu preso não fosse concluído no exíguo prazo de 81 dias, o acusado devia ser colocado em liberdade, por mais grave que fosse o crime imputado, ou por mais contundentes que fossem as provas contra ele" ${ }^{334}$.

Após a Súmula $n^{0} 52$ do Superior Tribunal de Justiça, o prazo final de contagem dos 81 dias foi passo a passo sendo antecipado na evolução do julgados subseqüentes. "O critério jurisprudencial dos 81 dias tinha como termo final a sentença de

\footnotetext{
${ }^{330}$ STJ, RHC 1081, Quinta Turma, Rel. Cid Flaquer Scartezzini, j. 17/04/1991, DJ de 06/05/1991.

${ }^{331}$ STJ, HC 834, Sexta Turma, Rel. Min. Dias Trindade, j. 29/10/1990, DJ de 19/11/1990.

${ }^{332}$ São indicados, ainda, como precedentes da Súmula $\mathrm{n}^{\circ} 52$ do Superior Tribunal de Justiça os seguintes arestos: STJ, RHC 1172, Sexta Turma, Rel. William Patterson, j. 14/05/1991, DJ de 03/06/1991; STJ, RHC 1262, Sexta Turma, Rel. José Cândido de Carvalho Filho, j. 96/08/1991, DJ de 26/08/1991; STJ, RHC 1716, Quinta Turma, Rel. José Dantas, j. 17/02/1992, DJ de 09/03/1992; STJ, HC 1153, Quinta Turma, Rel. Assis Toledo, j. 20/04/1992, DJ de 11/05/1992; STJ, RHC 1495, Quinta Turma, Rel. Edson Vidigal, j. 21/10/1991, DJ de 11/05/1992.

${ }^{333}$ STJ, RHC 239, Sexta Turma, Rel. Min. Carlos Thibau, j. 10/10/1989, DJ de 06/11/2989.

${ }^{334}$ Gustavo Henrique Righi Ivahy Badaró, op. cit., p. 33.
} 
primeiro grau. A súmula $\mathrm{n}^{\circ} 52$ antecipou o termo final de tal prazo para o término da instrução, isto é, a conclusão da oitiva das testemunhas de defesa. Por fim, um desvirtuamento da súmula $\mathrm{n}^{\circ} 64$ tem levado ao equivocadíssimo entendimento de que o termo final para se alegar o constrangimento ilegal, pelo excesso de prazo da prisão, é o término da oitiva das testemunhas de acusação" ${ }^{335}$.

Válida, a respeito, a crítica de SILVA FRANCO no sentido de que “deslocar para trás, antes da sentença de mérito, o ponto terminal do segmento processual a ser considerado, fazendo-o coincidir com o início da fase do art. 499 do Código de Processo Penal, equivale à criação de um 'tempo morto', idôneo a tangenciar o critério jurisprudencial já consagrado e a instalar o regime do caso concreto, sempre propício a decisões autoritárias e perigosas" 336 .

Finalmente, sob influência do Pacto de São José da Costa Rica e, principalmente, com a consagração da garantia da razoável duração do processo pela Emenda Constitucional $\mathrm{n}^{\mathrm{o}} 45$, a chamada jurisprudência dos 81 dias perdeu ainda mais sua força, passando a verificação do excesso da prisão pela análise do princípio da razoabilidade ${ }^{337}$. Por demonstrar, de forma muito didática, a maneira como o entendimento jurisprudencial foi se alterando ao longo do tempo até chegar à análise do excesso de prazo com base no princípio da razoabilidade, vale reproduzir aqui trecho escrito por SCARANCE FERNANDES:

"Mas a jurisprudência alterou essa posição, de forma lenta e gradativa, sendo os passos significativos dessa evolução:

a) a orientação de que o tempo de oitenta e um dias é exigível para o encerramento da instrução, não para a prolação da sentença, havendo mesmo forte inclinação no sentido de ser exigido esse prazo somente para o encerramento da prova acusatória;

\footnotetext{
${ }^{335}$ Idem, p. 34.

${ }^{336}$ Alberto Silva Franco, Crimes hediondos, $3^{\text {a }}$ ed., São Paulo, Revista dos Tribunais, 1994, p. 367.

${ }^{337}$ Cf. Alberto Silva Franco, "Prazo razoável e o Estado Democrático de Direito", Boletim IBCCrim v. 13, no 152, julho de 2005, pp. 6 e 7.
} 
b) a justificação do excesso de prazo em virtude de vários motivos grande número de acusados, complexidade da causa, necessidade da expedição de precatória, instauração de incidentes (insanidade mental, dependência toxicológica, falsidade documental);

c) a declaração de inexistência de constrangimento ilegal quando o excesso resultasse de diligências de interesse da defesa;

d) a afirmação de que o excesso deveria ser verificado em cada caso concreto, dentro de um critério de razoabilidade" ${ }^{338}$.

A utilização do princípio da razoabilidade acabou trazendo insegurança relativamente ao tempo de duração do processo com relação ao réu preso, já que, como demonstrado, a análise referente ao princípio da razoabilidade repousa em critérios bastante vagos e imprecisos ${ }^{339}$. É o que afirma SILVA FRANCO na seguinte passagem: “Com a introdução do critério da razoabilidade e com a inexistência de quantificação legal definidora da razoabilidade, o critério de oitenta e um dias perdeu sua força e surgiu, em substituição, o indiscriminado acolhimento da razoabilidade, a dano do direito de liberdade das pessoas. Sem nenhuma adequada motivação, dá-se à idéia de prazo razoável um caráter mágico, tornando-a idônea a justificar os mais absurdos abusos" ${ }^{\text {340 }}$.

A análise do excesso de prazo para a prisão passou, assim, a ser feita da seguinte maneira: levava-se em consideração o prazo de 81 dias apenas como um parâmetro inicial a ser adotado, mas as razões pelas quais o referido prazo foi superado são analisadas em cada caso concreto, verificando-se se há justificativa plausível para a demora. Do mesmo modo, o excesso de prazo para a prisão é contado até o término da instrução (ou da decisão de pronúncia, no caso do procedimento do tribunal do júri), e eventual demora posterior a esta etapa procedimental é analisada caso a caso ${ }^{341}$.

\footnotetext{
${ }^{338}$ Antonio Scarance Fernandes, Processo Penal... cit., p. 120.

${ }^{339}$ Ver, a respeito, o capítulo 3 deste trabalho.

${ }^{340}$ Alberto Silva Franco, "Prazo razoável...”, cit., pp. 6 e 7.

${ }^{341}$ Nesse sentido: STJ, HC 87458/RJ, Sexta Turma, Rel. Min. Maria Thereza de Assis Moura, j. 06/03/2008, DJ de 12/05/2008; STJ, HC 59406/PE, Sexta Turma, Rel. Min. Maria Thereza de Assis Moura, j. 25/03/2008, DJ de 22/04/2008; STJ, HC 71641/SP, Quinta Turma, Rel. Min. Laurita Vaz, j. 13/11/2007, DJ de 03/12/2007/ TJRJ, HC 2008.059.07768, Quinta Câmara, Rel. Des. Maria Helena Salcedo, j. 13/11/2008; TJRJ, HC 2008.059.06074, Sétima Câmara, Rel. Gilmar Augusto Teixeira, j. 23/09/2008.
} 
Em relação à lei 9.034/95, que dispõe sobre a repressão às organizações criminosas e que, em seu artigo $8^{\circ}$, prevê expressamente prazo para o término da instrução criminal - de 81 dias para réu preso e 120 dias para réu solto ${ }^{342}$ - o mesmo raciocínio referente ao princípio da razoabilidade tem sido invocado, analisando-se caso a caso se houve ou não justificativa razoável para a ultrapassagem do prazo legal para determinar-se a soltura do acusado preso cautelarmente.

O mesmo ocorre no âmbito da Justiça Militar, em que há prazo de 50 dias para o término da instrução criminal em relação ao acusado preso e de 90 dias para o acusado solto, nos termos do artigo 390 do Código de Processo Penal Militar ${ }^{343}$, considerando-se caso a caso as justificativas apontadas para a ultrapassagem do prazo legal ${ }^{344}$. Ressalte-se que é em razão da necessidade da preservação da hierarquia e disciplina no contexto das Forças Armadas, sobretudo no que diz respeito aos crimes propriamente militares, que se torna imprescindível a celeridade no julgamento de causas desta natureza ${ }^{345}$, sendo essa, aliás, uma das principais justificativas para a existência e manutenção de uma Justiça especializada.

$\mathrm{Na}$ Justiça comum, com a recente reforma processual, trazida especialmente com a aprovação das Leis 11.719/08 e 11.689/08, houve uma preocupação em estabelecer um prazo máximo de duração do processo, ao menos até a prolação da sentença. Com a concentração dos atos da instrução em uma audiência una, que deverá ocorrer no máximo

\footnotetext{
${ }^{342}$ Artigo $8^{\circ}$ com a redação dada pela Lei 9.303/96: "O prazo para encerramento da instrução criminal, nos processos por crime de que trata esta Lei, será de 81 (oitenta e um) dias, quando o réu estiver preso, e de 120 (cento e vinte) dias, quando solto".
}

343 Art. 390. O prazo para a conclusão da instrução criminal é de cinqüenta dias, estando o acusado preso, e de noventa, quando solto, contados do recebimento da denúncia. $\S 1^{\circ}$ Não será computada naqueles prazos a demora determinada por doença do acusado ou defensor, por questão prejudicial ou por outro motivo de força maior justificado pelo auditor, inclusive a inquirição de testemunhas por precatória ou a realização de exames periciais ou outras diligências necessárias à instrução criminal, dentro dos respectivos prazos".

${ }^{344}$ Nesse sentido, conferir os seguintes julgados do Superior Tribunal Militar: STM, HC 2008.01.034475-6, Rel. Min. Brig. Aer. José Américo dos Santos, j. 22/04/2008, DJ de 23/05/2008 (“A jurisprudência desta Corte Castrense e de outros Tribunais Superiores admitem a flexibilidade dos prazos da instrução criminal, por motivo de força maior. Não detectada qualquer ilegalidade ou abuso de poder"); STM, HC 2005.01.034053-0, Rel. Min. Gen. Ex. Valdesio Guilherme, j. 01/08/2005, DJ de 23/08/2005; STM, HC 2005.01.034018-1, Rel. Min. Brig. Aer. Henrique Marini e Souza, j. 26/04/2005, DJ de 20/05/2005; STM, HC 2005.01.034126-9, Rel. Min. Gen. Ex. Sérgio Ernesto Alves Conforto, j. 21/02/2006, DJ de 28/03//2006; STM, HC 2005.01.034129-3, Rel. Min. Gen. Ex. Antonio Apparício Ignácio Domingues, j. 16/03/2006, DJ de 09/05/2006; STM, HC 2006.01.034286-9, Rel. Min. Alm. Esq. Marcos Augusto Leal de Azevedo, j. 27/02/2007, DJ de 04/04/2007.

345 STM, HC 2008.01.034464-0, Rel. Brig. Aer. William de Oliveira Barros, j. 04/03/2008, sem data de publicação. 
em 30 dias após o recebimento definitivo da denúncia, no procedimento sumário ${ }^{346}$ e em 60 dias a partir do mesmo marco no caso do procedimento ordinário ${ }^{347}$, perde ainda mais força esta distinção entre prazo para o término da instrução criminal e para o término do processo em primeira instância ${ }^{348}$, já que o término da instrução e a prolação da sentença ocorrem num mesmo ato processual.

Sendo recente a reforma, não se pode prever como reagirão os tribunais à introdução deste novo limite temporal para a realização da audiência de instrução e julgamento e se este terá algum reflexo na análise relativa ao excesso de prazo da prisão, ou mesmo da duração do processo.

$\mathrm{Na}$ doutrina, algumas vozes já se levantaram defendendo que o artigo 412 do Código de Processo Penal, com sua nova redação dada pela Lei 11.689/2008, aplicável, a princípio, ao procedimento do tribunal do júri, pode ser aplicado analogicamente ao procedimento ordinário e sumário, caracterizando um limite temporal máximo de duração do procedimento até a prolação da sentença. Este entendimento foi defendido por DEZEM e JUNQUEIRA, logo após a entrada em vigor das leis 11.689, 11.690 e 11.719 de 2008, nos seguintes termos: “Acreditamos que por estar inserido no título do "procedimento comum' no Código de Processo Penal, e por maximizar garantia constitucional, o marco para aferição de excesso de prazo no procedimento ordinário também deve ser reconhecido como a 'conclusão do procedimento', quedando afastada a referida polêmica sobre o marco temporal para aferição do excesso de prazo"349.

\footnotetext{
${ }^{346}$ Artigo 531 do Código de Processo Penal: "Na audiência de instrução e julgamento, a ser realizada no prazo máximo de 30 (trinta) dias, proceder-se-á à tomada de declarações do ofendido, se possível, à inquirição das testemunhas arroladas pela acusação e pela defesa, nesta ordem, ressalvado o disposto no art. 222 deste Código, bem como aos esclarecimentos dos peritos, às acareações e ao reconhecimento de pessoas e coisas, interrogando-se, em seguida, o acusado e procedendo-se, finalmente, ao debate".

${ }^{347}$ Artigo 400 do Código de Processo Penal: "Na audiência de instrução e julgamento, a ser realizada no prazo máximo de 60 (sessenta) dias, proceder-se-á à tomada de declarações do ofendido, à inquirição das testemunhas arroladas pela acusação e pela defesa, nesta ordem, ressalvado o disposto no art. 222 deste Código, bem como aos esclarecimentos dos peritos, às acareações e ao reconhecimento de pessoas e coisas, interrogando-se, em seguida, o acusado".

${ }^{348}$ Defendendo que o término da instrução não interfere no marco final da garantia da razoável duração do processo, ver Guilherme Madeira Dezem e Gustavo Octaviano Diniz Junqueira, "Prazo para encerramento do procedimento", Boletim do IBCCrim n ${ }^{\circ} 188$, ano 16, julho de 2008, p. 29: "O encerramento da instrução nada interfere na legislação advinda do potencial descumprimento da garantia da razoável duração do processo, tampouco tem tal efeito a oitiva das testemunhas de acusação. É certo que apenas impondo célere fim do procedimento, e possível fím do processo - o que se dá com a sentença - é maximizada a garantia constitucional"'.

${ }^{349}$ Idem, p. 29.
} 
Com efeito, ao que tudo indica, sendo o prazo para a realização da audiência de instrução e julgamento de 30 dias, em se tratando de procedimento sumário ou de procedimento referente aos crimes previstos na Lei 11.343/06, em que não for necessária a realização de exame de dependência toxicológica, 60 dias para o procedimento ordinário, e de 90 dias para os casos em que for necessária a realização do exame de dependência toxicológica de acordo com a Nova Lei Antidrogas ${ }^{350}$, este deve ser o marco utilizado para a aferição do excesso de prazo para a prisão, pois marca tanto o término da instrução criminal quanto do próprio julgamento, de acordo com o legislador $^{351}$.

Nos termos do artigo 403, "não havendo requerimento de diligências, ou sendo indeferido, serão oferecidas alegações finais orais por 20 minutos, respectivamente, pela acusação e pela defesa, prorrogáveis por 10, proferindo o juiz, a seguir, sentença”. Há a possibilidade de cisão da audiência, portanto, no caso em que for deferida a realização de diligências complementares. Nesse caso, a análise de excesso de prazo para a prisão e a decisão sobre a manutenção da custódia deverá ser feita de acordo com os critérios já consagrados na jurisprudência, de complexidade da causa, conduta do acusado, e forma de condução do processo pelas autoridades judiciais, considerando, para tanto, a natureza da diligência requerida.

O $\S 3^{\circ}$ do mesmo dispositivo prevê, aliás, a possibilidade de cisão da audiência, no caso em que o juiz considerar "a complexidade do caso ou o número de acusados", hipótese em que será concedido às partes o prazo de 5 dias sucessivamente para a apresentação de memoriais, após o que será proferida a sentença em 10 dias. Em se tratando de cisão da audiência una por este motivo, o prazo a ser considerado para fins de excesso de prazo deverá ser acrescido de 20 dias, portanto.

\footnotetext{
${ }^{350}$ Nos termos do artigo 56, $\S 2^{\circ}$ da Lei 11.343/06: "A audiência a que se refere o caput deste artigo instrução e julgamento] será realizada dentro dos 30 dias seguintes ao recebimento da denúncia, salvo se determinada a realização de avaliação para atestar a dependência de drogas, quando se realizará em 90 dias".

${ }^{351}$ Já a apontar para este mesmo entendimento, pode-se destacar o seguinte julgado do Tribunal de Justiça do Estado do Rio de Janeiro: HC 2008.059.07885, Oitava Câmara, Rel. Des. Gilmar Augusto Teixeira, j. 27/11/2008: "Afirmou o magistrado haver despachado o feito em 23 de outubro e, se a audiência foi designada para o mês seguinte, cumpriu o julgador o disposto no novel art. 400, do CPP que determina a realização da audiência de instrução e julgamento para o prazo máximo de 60 dias, evidentemente que não contados do recebimento da denúncia, mas da data em que, apresentada a defesa prévia, decide o magistrado quanto à absolvição sumária ou a designação da audiência de instrução de julgamento. Nessa esteira, não existe excesso de prazo".
} 
Independentemente de se tratar de acusado preso ou solto e mesmo havendo a necessidade de cisão de audiência, o prazo de 90 deve ser respeitado como limite máximo de duração do procedimento (sendo que, no procedimento do tribunal do júri, até a prolação da decisão de pronúncia).

Por não haver previsão de qualquer sanção para o seu descumprimento, a previsão de tal prazo, por certo, perde muito de sua eficácia e, provavelmente, será utilizado apenas como um parâmetro de referência, prosseguindo-se na análise própria do princípio da razoabilidade, com os riscos, já exposto neste trabalho, de vagueza e indeterminação dos critérios de aferição envolvidos no conceito.

\subsubsection{Fase recursal}

Uma vez interpostos recursos pelas partes impugnando a sentença, a garantia da razoável duração do processo passa a incidir também nesta fase da persecução penal, até que a tutela jurisdicional seja prestada em caráter definitivo, resolvendo-se o mérito da causa ${ }^{352}$.

Deve ser feita novamente aqui, todavia, a distinção entre o direito a responder ao processo em liberdade, em razão do excesso de prazo da prisão cautelar, e o direito a ser julgado em um prazo razoável.

Com relação ao acusado solto, não havendo previsão de prazo para o julgamento dos recursos, a razoabilidade da duração da fase recursal deve ser aferida em conformidade com os critérios da adequação, necessidade e proporcionalidade em sentido estrito, assim como de complexidade da causa, comportamento do acusado e conduta das autoridades responsáveis pela condução do processo.

Especificamente no que se refere ao acusado preso e ao excesso de prazo para a prisão cautelar, existe divergência quanto ao efeito dos recursos especial e

\footnotetext{
${ }^{352}$ Reconhecendo a demora irrazoável no julgamento de recursos, conferir, a título de exemplo, os seguintes julgados: STF, HC 86575, Segunda Turma, Rel. Min. Joaquim Barbosa, j. 06/03/2007, DJ de 13/04/2007; STF, HC 88560/SP, Primeira Turma, Rel. Sepúlveda Pertence, j. 08/08/2006, DJ de 25/08/2006; STF, HC 84921/SP, Primeira Turma, Rel. Min Eros Grau, j. 15/02/2005, DJ de 11/03/2005; STF, HC-MC-QQ 84539/SP, Primeira Turma, Rel. Carlos Britto, j. 16/12/2004, DJ de 14/10/2005; STJ, HC 85671/SP, Quinta Turma, Rel. Min. Napoleão Nunes Maia Filho, j. 03/04/2008, DJ de 28/04/2008; STJ, HC 81996/PE, Sexta Turma, Rel. Min. Maria Thereza de Assis Moura, j. 29/11/2007, DJ de 17/12/2007.
} 
extraordinário, e se seria admissível a execução provisória da pena se pendentes apenas estas duas espécies de recurso. A discussão sobre o efeito dos recursos extraordinário e especial e a possibilidade de execução provisória da pena recai sobre o prazo da prisão, mas não tem qualquer reflexo sobre a duração do processo, que, com a interposição de novos recursos, não se encerra, ficando a situação do acusado ainda pendente de uma decisão firme. Se for admitida a possibilidade de execução provisória, ficaria afastada a alegação de excesso de prazo para a prisão, já que a custódia, nesta hipótese, já estaria sendo aplicada a título de pena. Se não se admitir a possibilidade de execução provisória, o excesso de prazo para a prisão persiste mesmo estando pendentes apenas o recurso especial e o extraordinário.

Como a redação do artigo 637 do Código de Processo Penal, segundo o qual “o recurso extraordinário não tem efeito suspensivo, e uma vez arrazoados pelo recorrido os autos do traslado, os originais baixarão à primeira instância para a execução da sentença”, dá a entender que seria possível a execução provisória da pena, muita divergência existe acerca da aplicabilidade e constitucionalidade deste dispositivo, tendo em vista o princípio da presunção de inocência, que, nos termos do artigo $5^{\circ}$, inciso LVII, da Constituição da República, expressamente refere que "ninguém será considerado culpado até o trânsito em julgado de sentença penal condenatória”.

A possibilidade de execução provisória em matéria penal, antecipando o início do cumprimento da pena em prejuízo do acusado, apesar de ser veementemente refutada pela doutrina ${ }^{353}$, encontra-se sob intenso debate no âmbito do Superior Tribunal de Justiça e do Supremo Tribunal Federal.

No Supremo Tribunal Federal foi pacífica, durante muito tempo, a orientação no sentido de ser possível a execução provisória da pena na pendência de recurso especial e extraordinário ${ }^{354}$. Com o julgamento do habeas corpus n ${ }^{\circ}$ 91333/ $\mathrm{MG}^{355}$, a Corte Suprema, por sua Segunda Turma, modificou o entendimento até então adotado, passando a considerar que o artigo 637 do Código de Processo Penal não foi recepcionado

\footnotetext{
${ }^{353}$ Conferir, com esse entendimento, Rogério Lauria Tucci, Direitos e Garantias... cit., pp. 279-285.

${ }^{354}$ Confiram-se alguns julgados, dentre muitos, que exemplificam a adoção desse entendimento: STF, HC 89952/MG, Segunda Turma, Rel. Min. Joaquim Barbosa, j. 15/05/2007, DJ de 28/06/2007; STF, HC 91675/PR, Primeira Turma, Rel. Min. Cármen Lúcia, j. 04/09/2007, DJ de 07/12/2007; STF, HC 90645/PE, Primeira Turma, Rel. Min. Marco Aurélio, Rel. p/ acórdão Min. Menezes Direito, j. 11/09/2007, DJ de 14/11/2007; HC 91675/PR, Primeira Turma, Rel. Min, Cármen Lúcia, j. 04/09/2007, DJ de 07/12/2007.
}

${ }^{355}$ STF, HC 91333/MG, Segunda Turma, Rel. Min. Eros Grau, j. 09/10/2007, DJ de 18/12/2007. 
pela Constituição brasileira ${ }^{356}$. Na ementa do aresto em questão, registrou-se a seguinte conclusão: "A Lei de Execução Penal condicionou a execução da pena privativa de liberdade ao trânsito em julgado da sentença condenatória. A Constituição do Brasil de 1988 definiu, em seu artigo $5^{\circ}$, inciso LVIII, que 'ninguém será considerado culpado até o trânsito em julgado de sentença penal condenatória'. Daí a conclusão de que os preceitos veiculados pela Lei 7.210/84, além de adequada à ordem constitucional vigente, sobrepõem-se, temporal e materialmente, ao disposto no art. 637 do CPP. Disso resulta que a prisão antes do trânsito em julgado da condenação somente pode ser decretada a título cautelar" 357 .

A questão foi recentemente afetada ao Pleno no julgamento do habeas corpus $\mathrm{n}^{\mathrm{o}} 84078^{358}$, que se encontra com pedido de vista por parte do Ministro Menezes Direito desde 09/04/2008, demonstrando que a discussão ainda está sob intenso debate e que não encontra entendimento tranqüilo no âmbito daquela Corte.

No âmbito do Superior Tribunal de Justiça, ainda há divergência sobre o tema e, mesmo após o precedente já referido do Supremo Tribunal Federal, prosseguiu-se com entendimentos destoantes, ora admitindo a possibilidade de execução provisória ${ }^{359}$, ora não a admitindo ${ }^{360}$.

${ }^{356}$ Nesse mesmo sentido: STF, HC 91176/SP, Segunda Turma, Rel. Min Eros Garu, j. 16/10/2007, DJ de 19/12/2007; STF, HC 85417/RS, Segunda Turma, Rel. Min. Ellen Gracie, Rel. p/ acórdão Min. Eros Grau, j. 02/09/2008, DJ de 14/11/2008; STF, HC 94951/RN, Segunda Turma, Rel. Min Ellen Gracie, j. 07/10/2008, DJ de 24/10/2008.

${ }^{357}$ STF, HC 91232, Segunda Turma, Rel. Min. Eros Grau, j. 06/11/2007, DJ de 07/12/2007.

${ }^{358}$ STF, HC 84078, Pleno, Rel. Min, Eros Grau, pendente de julgamento.

359 STJ, HC 91818/SP, Quinta Turma, Rel. Min. Félix Fischer, j. 07/02/2008, DJ de 07/04/2008; STJ, HC 85803/SP, Quinta Turma, Rel. Min. Napoleão Nunes Maia Filho, j. 21/02/2008, DJ de 17/03/2008; STJ, HC 90846/SP, Quinta Turma, Rel. Min Jane Silva (Desembargadora Convocada do TJMG), Rel. p/ acórdão Min. Félix Fischer, j. 04/03/2008, DJ de 23/06/2008; STJ, HC 96054/SP, Quinta Turma, Rel. Min. Laurita Vaz, j. 27/03/2008, DJ de 22/04/2008, STJ, HC 94557/SP, Quinta Turma, Rel. Min. Jorge Mussi, j. 27/03/2008, DJ de 19/05/2008, STJ, HC 104993/MS, Quinta Turma, Rel. Min. Napoleão Nunes Maia Filho, j. 12/08/2008, DJ de 15/09/2008; STJ. HC 82815/SP, Quinta Turma, Rel. Min. Laurita Vaz, j. 06/11/2008, DJ de 01/12/2008, STJ, HC 102747/SP, Quinta Turma, Rel. Min. Napoleão Nunes Maia Filho, j. 11/11/2008, DJ de $15 / 12 / 2008$.

${ }^{360}$ STJ, HC 73.578/RS, Sexta Turma, Rel. Min. Carlos Fernando Mathias (Juiz Convocado do TRF $1^{\text {a }}$ Região), j. 30.08.2007, DJ de 15/10/2007; STJ, HC 47.314/SP, Rel. Min. Hélio Quaglia Barbosa, j. 28/03/2006, DJ de 15/05/2006; STJ, HC 51004/SP, Sexta Turma, Rel. Nilson Naves, j. 20/04/2006, DJ de 12/06/2006; STJ, HC 72726/SP, Sexta Turma, Rel. Min. Maria Thereza de Assis Moura, j. 20/11/2007, DJ de 10/12/2007; STJ, HC 76725/DF, Sexta Turma, Rel. Min. Maria Thereza de Assis Moura, j. 18/12/2007, DJ de 25/02/2008; STJ, HC 93550/PR, Sexta Turma, Rel. Min. Maria Thereza de Assis Moura, j. 13/12/2007, DJ de 11/02/2008; STJ, HC 105810/RS, Sexta Turma, Rel. Min. Og Fernandes, j. 28/08/2008, DJ de 15/09/2008. 


\subsubsection{Prazo razoável na execução penal}

A idéia que se tem, num primeiro momento, é a de que, uma vez encerrada a ação penal com a prestação jurisdicional definitiva, afasta-se completamente a incidência da garantia da razoável duração do processo. Mas a garantia tem um alcance muito mais amplo, atingindo também o processo de execução.

Pelo próprio desdobramento da garantia de que ninguém pode ficar preso por mais tempo do que determina a lei, impõe-se o respeito incondicional ao quantum de pena a ser cumprido pelo sentenciado. Assim, o limite temporal máximo do processo de execução é o próprio quantum da pena a ser cumprido, por imposição do princípio da legalidade, devendo-se o pagamento de indenização para quem ficar preso além do tempo fixado na sentença ${ }^{361}$.

Assim, a discussão sobre a garantia da razoável duração do processo no âmbito da execução penal aplica-se para o tempo de apreciação dos incidentes da execução penal, que também devem ocorrer em prazo razoável.

Infelizmente, é bastante comum, em algumas Varas de Execução Penal com maior número de presos sob sua jurisdição, como no Estado de São Paulo e Rio de Janeiro, que um pedido de progressão para o regime semi-aberto venha a ser apreciado apenas quando o apenado já reúne tempo de cumprimento de pena suficiente para a progressão para o regime aberto ${ }^{362}$, consubstanciando uma demora que traz reflexos gravíssimos sobre a liberdade de locomoção do indivíduo, que acaba limitada em grau mais intenso do que o determinado, além de provocar efeitos irrecuperáveis relativamente aos fins buscados pela execução penal, que encontra na progressividade o seu maior mecanismo para alcançar a ressocialização do condenado.

\footnotetext{
${ }^{361}$ É o que determina o inciso LXXV do artigo $5^{\circ}$ da Constituição Federal: "o Estado indenizará o condenado por erro judiciário, assim como o que ficar preso além do tempo fixado na sentença”.

${ }^{362}$ No TJRJ, HC 2008.059.06060, Quinta Câmara, Rel. Des. Cairo Ítalo David, j. 06/11/2008, por exemplo, concedeu-se a ordem para conceder livramento condicional a preso que se encontrava ainda em regime fechado. Considerou-se, nesse caso, que "a pena está quase no fim e não se justifica o prolongamento indefinido da prisão em regime fechado".
} 
Não existe na Lei de Execução Penal a previsão de um prazo para que o juiz decida sobre um incidente da execução. De qualquer modo, o pedido de progressão, por exemplo, deve ser apreciado em tempo suficiente para não prejudicar o próprio período de gozo do cumprimento da pena em regime menos severo ${ }^{363}$. Podem ser encontrados diversos julgados no Brasil em que é reconhecida a incidência da garantia da razoável duração do processo no âmbito da execução penal, rechaçando-se a demora na decisão de incidentes da execução, especialmente de pedidos de progressão de regime ${ }^{364}$.

\section{CRITÉRIOS A SEREM UTILIZADOS NA FIXAÇÃO DE UM “PRAZO RAZOÁVEL DE DURAÇÃO DA PERSECUÇÃO PENAL”}

\subsection{Critérios consagrados internacionalmente}

Para a compreensão do que vem a ser o prazo razoável de duração de determinado processo criminal, além dos critérios da adequação, necessidade e proporcionalidade em sentido estrito, trazidos pelo princípio da razoabilidade, existem ainda outras ferramentas interpretativas valiosas presentes em decisões proferidas no âmbito dos dois principais tribunais de direitos humanos, o Tribunal Europeu e a Corte Interamericana de Direitos Humanos.

Ao lidar com o conceito bastante permeável de "prazo razoável", indispensável para se apurar a violação de direitos e garantias individuais por cada país demandado, cada um com prazos de duração distintos ou, como é o caso do próprio Brasil, sem nenhum prazo de duração máxima do processo definido em lei, estes tribunais precisaram se servir de alguns critérios de avaliação gerais para poder definir, em cada

\footnotetext{
${ }^{363}$ Cf. Luiz Nicolitt, A duração razoável do processo, Rio de Janeiro, Lumen Juris, 2006, p. 74.

${ }^{364}$ No julgamento do recurso ordinário em habeas corpus $\mathrm{n}^{\circ}$ 20700, do Rio de Janeiro, a Sexta Turma do Superior Tribunal de Justiça, por unanimidade, considerou que "a demora injustificável, que extrapola o razoável para o tipo de diligência requerida, transmuda-se em ilegalidade, não se podendo exigir do recorrente que aguarde indefinidamente pela apreciação de seu pedido de progressão", concedendo, assim, ao recorrente, o direito de aguardar a decisão sobre o incidente em regime menos gravoso (julgado em 5 de junho de 2007, e publicado no DJ de 18 de junho de 2007). No mesmo sentido, também o RHC 8664/RJ, Quinta Turma, Rel. Min. José Arnaldo da Fonseca, DJ de 06/09/1999; RHC 5969/RJ, Quinta Turma, Rel. Min. Edson Vidigal, DJ de 24/02/1997. No julgamento do habeas corpus $n^{\circ}$ 37440/RS, a Quinta Turma, afastou, também por unanimidade, a necessidade de realização de exame pelo Centro de Observação Criminológica, para evitar maior demora na apreciação do pedido de progressão de regime, determinando, ainda o imediato julgamento do pedido (Rel. Min. Gilson Dipp, DJ de 09/02/2005).
} 
caso concreto, se um processo ultrapassou a linha do razoável, com a conseqüente responsabilização do Estado em âmbito internacional.

Por lançar maior luz ao tema do presente trabalho, impõe-se a breve exposição de cada critério criado, por sua utilidade prática e relevância no controle judicial em relação à efetivação da garantia da razoável duração do processo.

\subsubsection{Entendimento do Tribunal Europeu de Direitos Humanos para a aferição do prazo razoável de duração da persecução penal}

Inicialmente, a Comissão Européia estipulou sete critérios que entendeu serem relevantes para a análise acerca da razoabilidade da duração de processos criminais. Foi no caso Wemhoff, julgado em 1968, que se criou a chamada "doutrina dos sete critérios". Wemhoff era cidadão alemão acusado de praticar fraudes contra o sistema financeiro, que atingiram instituições alemãs e suíças. Detido em 9 de novembro de 1961, apenas foi condenado em primeira instância em 7 de abril de 1965. A denúncia foi proposta contra a Alemanha perante a Comissão, que considerou ter ocorrido a violação ao direito a ser julgado num prazo razoável.

A Comissão especificou, neste caso, sete fatores que precisariam ser levados em conta para se verificar a razoabilidade tanto do tempo de prisão quanto do tempo de duração do próprio processo: 1) a duração da prisão cautelar por si só; 2) a duração da prisão cautelar em relação à natureza do crime, à pena cominada, e à pena a ser aplicada em caso de condenação; 3) os efeitos pessoais sobre o acusado, tanto de ordem material, como moral, entre outros; 4) a conduta do acusado e quanto ela pôde influenciar para a demora do processo; 5) as dificuldades para a investigação do caso (complexidade dos fatos, quantidade de testemunhas e de acusados, dificuldades probatórias, etc.); 6) a maneira como a investigação foi conduzida; 7) a conduta das autoridades judiciais ${ }^{365}$.

${ }^{365}$ Daniel R. Pastor, El plazo razonable..., cit., p. 112. 
Para a Comissão, estes critérios permitem uma interpretação coerente e desprovida de qualquer aparência de arbitrariedade, cobrindo todas as situações fáticas possíveis, sem esgotar, de qualquer modo, a possibilidade de criação de outros critérios ${ }^{366}$.

Ainda segundo a Comissão européia, estes sete critérios devem ser analisados em conjunto, mas é possível que alguns ou apenas um deles tenha importância suficiente para conduzir à conclusão de que houve violação da garantia da razoável duração do processo $^{367}$. No caso Wemhoff, a Comissão entendeu que a duração da prisão cautelar foi excessiva em si mesma, além de ser desproporcional em relação às possíveis penas aplicáveis em caso de condenação, e ter causado efeitos danosos ao acusado. Já com relação ao processo, entendeu a demora justificável, em razão da complexidade da causa, por serem diversos os crimes apurados, todos contra o sistema financeiro ${ }^{368}$.

Todavia, a doutrina dos sete critérios não foi aceita pelo Tribunal Europeu de Direitos Humanos ao argumento de que "esta doutrina é somente uma medida de disciplina intelectual" e que diversas são as circunstâncias subjetivas, especialmente de interesse público, que levam as autoridades a manter a privação da liberdade de uma pessoa, entendendo necessário, portanto, analisar os motivos que cada Estado apontava para a demora do processo. Adotou-se, então, uma linha bastante subjetiva de apreciação, entendendo-se, naquele caso, que a duração da prisão de Wemhoff, assim como do próprio processo, havia se mantido dentro do razoável, sem indicar qualquer critério adotado para chegar-se a esta conclusão.

Nos casos posteriores, o Tribunal acabou se aproximando destes sete critérios propostos pela Comissão e passou a aplicar uma lista mais reduzida, de apenas três critérios: o comportamento das partes, a complexidade da causa e a conduta das autoridades responsáveis pela condução do processo.

É de se levar em conta que, dos sete critérios já mencionados, estão contemplados claramente quatro deles, de forma resumida, nestes três: a conduta do acusado e a conduta das autoridades judiciais, resumidos no critério "o comportamento das partes"; as dificuldades para a investigação do caso, coincidindo com o critério da

\footnotetext{
${ }^{366}$ Idem, ibidem,.

${ }^{367}$ Idem, ibidem.

${ }^{368}$ Idem, p. 114.
} 
"complexidade da causa"; e a maneira como a investigação foi conduzida, sintetizada no critério da "conduta das autoridades responsáveis pela condução do processo".

A utilização dos três outros critérios (duração da prisão cautelar e sua relação com a pena abstratamente cominada ou a aplicável em perspectiva, assim como os efeitos sobre a pessoa do acusado), na forma em que propostos pela Comissão, não devem ser excluídos também da análise judicial, por serem de bastante relevância prática no que se refere à aplicação da garantia da razoável duração do processo.

Por esta razão, passaremos a analisar os sete critérios propostos pela Comissão Européia.

\subsubsection{Efetiva duração da prisão cautelar}

A Comissão Européia de Direitos Humanos considerou que a duração efetiva da prisão cautelar deveria ser um fator levado em conta na análise da razoabilidade do tempo de duração dos processos em razão dos graves efeitos provocados ao acusado pela imposição de uma medida cautelar tão restritiva como a prisão.

É verdade que a duração da prisão em si mesma não é um indicativo seguro para se determinar se foi ou não extrapolado o prazo razoável de duração do processo, já que outras circunstâncias podem ter incidido no curso do procedimento que justificassem um período de prisão longo, em termos absolutos. "Um período de prisão preventiva longo não pode ser, por si só, um indicador de irrazoabilidade, uma vez que motivos relevantes, como a própria conduta do acusado, podem determinar o retardamento do processo"369.

Todavia, o tempo pelo qual alguém se submete a tamanha restrição em sua liberdade de locomoção deve representar relativamente algum peso na análise da razoabilidade da duração do processo, especialmente levando-se em consideração que deve haver preferência no julgamento dos processos em que há a imposição de prisão cautelar, e, dentre estes, daqueles em que o acusado estiver há mais tempo preso.

Esta escala de preferência existe, aliás, no ordenamento jurídico brasileiro, quando trata da preferência para julgamento no procedimento do tribunal do júri. $\mathrm{O}$ artigo

${ }^{369}$ Aury Lopes Jr. e Gustavo Henrique Badaró, op. cit., p. 50. 
429 do Código de Processo Penal dispõe que "salvo motivo relevante que autorize alteração na ordem dos julgamentos, terão preferência: I - os acusado presos; II - dentre os acusados presos, aqueles que estiverem há mais tempo na prisão; III - em igualdade de condições, os precedentemente pronunciados" ${ }^{370}$. A mesma regra deve ser aplicada, por analogia, aos demais procedimentos, já que a ratio do dispositivo em questão é proteger a liberdade do indivíduo, opção legislativa absolutamente compatível com a garantia constitucional da presunção de inocência, pois tem em vista a provisoriedade da prisão cautelar $^{371}$.

Neste critério, a Comissão analisa a duração da prisão cautelar em si mesma, sem confrontá-la com a pena cominada ao delito apurado. Para tanto, leva-se em consideração, em um primeiro momento, se a legislação do Estado-parte demandado possui algum tipo de regra de limitação temporal da prisão, e se este foi extrapolado no caso concreto.

Em muitas ocasiões, a Comissão européia apenas levou em consideração, no que se refere a este critério, o tempo em que o acusado aguardava preso na expectativa de uma decisão de mérito, afirmando, de forma genérica, não ser tolerável manter uma pessoa presa durante tanto tempo na incerteza quanto a seu futuro ${ }^{372}$. Adverte, ainda, que quanto maior o tempo de duração de uma prisão cautelar, mais difícil é ser absolvido ao final, pois se acaba invertendo a presunção de inocência e o acusado passa a se defender com vontade consideravelmente diminuída ${ }^{373}$.

\footnotetext{
${ }^{370}$ Dispositivo muito semelhante já existia antes das alterações trazidas pela Lei 11.689/2008. A antiga redação do artigo 431 do Código de Processo Penal previa que "salvo motivo de interesse público que autorize alteração na ordem do julgamento dos processos, terão preferência: I - os réus presos; II - dentre os presos; III - em igualdade de condições, os mais antigos na prisão; III - em igualdade de condições, os que tiverem sido pronunciados há mais tempo".
}

371 “Assim, o prazo da prisão cautelar está intimamente vinculado ao princípio da provisoriedade. A provisoriedade está relacionada ao fator tempo, de modo que toda prisão cautelar deve(ria) ser temporária, de breve duração. Manifesta-se, assim, na curta duração que deve ter a prisão cautelar, até porque é apenas a tutela de um situação fática (provisionalidade) e não pode assumir contornos de pena antecipada" (Cf. Aury Lopes Jr. e Gustavo Henrique Badaró, op. cit., p. 50).

372 Destaca-se o voto do juiz Zekia, proferido em 27/06/1968, no Caso Neumeister, em que o acusado, cidadão austríaco, ficou detido provisoriamente por mais de sete anos, enquanto se apurava a prática de crime contra a ordem tributária, assinalando que "em uma sociedade democrática, o direito de manter um homem por mais de sete anos na incerteza, na inquietude e na angústia que causa a ignorância do que será feito dele, com os sofrimentos que isto lhe causa, a ele e à sua família, na vida profissional e social, constitui, na minha opinião, uma clara violação do direito garantido pelo artigo 6.1 de que se trata".

${ }^{373}$ Caso Wemhoff, sentença de 27/07/1968. 
No caso Stögmuller, cuja sentença foi prolatada em 10/11/1969, contra a Áustria, o critério da efetiva duração da prisão cautelar foi analisado de maneira diferenciada, entendendo-se que, independentemente do tempo que durou a medida constritiva em si mesma, se essa se prolongou por mais tempo do que deveria, uma vez cessadas as razões que levaram à sua decretação, haveria excesso de prazo na prisão ${ }^{374}$.

No caso Ringeisen, cuja sentença foi prolatada em 16/07/1971, contra a Áustria, o mesmo tipo de análise foi reproduzido. Ringeisen era acusado de estelionatos cometidos em operações comerciais e, com a sua falência decretada, a Comissão considerou que não haveria como colocar em risco o processo com a reiteração das condutas delitivas, pois não poderia mais se utilizar da empresa com a qual operava suas fraudes $^{375}$. A partir disso, o tempo em que foi mantido preso, sem que persistissem os fundamentos cautelares, foi reconhecido como irrazoável.

\subsubsection{Duração da prisão cautelar em relação à pena a ser aplicada em caso de condenação}

Este critério vem complementar o anterior, no seguinte sentido: uma prisão cautelar pode ser em si mesmo curta, talvez bem inferior ao prazo máximo de duração previsto na legislação de determinado país, mas, em comparação com a pena aplicável em caso de condenação, pode se mostrar excessiva. Quanto mais a prisão se aproxima daquele quantum aplicável em caso de condenação, mais ilusória se torna a garantia da presunção de inocência, pois o acusado já teria, ao final do processo, cumprido toda a pena que deveria suportar caso viesse a ter a sua culpa comprovada. Se for absolvido, terá cumprido toda a pena indevidamente, tratado concretamente como culpado mesmo sendo inocente. Se for condenado, já terá cumprido toda a pena durante o processo, e igualmente terá sido tratado como culpado prematuramente, e a pena perderá o seu sentido de punição.

A ponderação da duração da privação cautelar em relação à pena abstratamente cominada ou ainda à pena provável a ser aplicada em caso de condenação

\footnotetext{
374 "Desaparecidos os motivos que autorizam constitucionalmente o encarceramento preventivo, este se torna ilegítimo, independentemente de sua curta ou larga duração". Cf. sentença da Corte no caso Stögmuller. Ver, a respeito, Daniel R. Pastor, El plazo razonable..., cit., p. 128.

${ }^{375}$ Idem, p. 134.
} 
passa necessariamente por uma análise própria do critério da proporcionalidade em sentido estrito, como já visto no item 4.3.

Se o processo é apenas um instrumento que pode, ou não, levar à aplicação da pena, não tem sentido que a privação da liberdade determinada apenas para assegurar a eficácia do meio ultrapasse temporalmente a sanção ao final aplicável por meio do processo.

É de se advertir, ainda, que a tendência do Tribunal Europeu de Direitos Humanos é aplicar o princípio da proporcionalidade de molde a proteger o acusado que se encontra encarcerado, evitando que este fique preso por tempo demais em relação à pena cominada, especialmente nos casos em que o delito não é tão grave. O raciocínio inverso, de que em crimes mais graves, aos quais são cominadas penas mais elevadas, restaria justificada a prisão cautelar por longos períodos, não encontra respaldo naquela Corte. Justamente para evitar esse tipo de raciocínio é que os critérios devem ser analisados de maneira conjunta ${ }^{376}$.

\subsubsection{Efeitos sobre o acusado}

Como já explicitado anteriormente, quando foram analisadas as razões pelas quais se justifica a existência de um direito a ser julgado num prazo razoável ${ }^{377}$, o processo traz ao acusado danos relevantes, tanto materiais quanto morais, estando preso ou não, pois o mero fato de estar sob acusação penal atinge negativamente a sua liberdade e a sua vida.

Por esta razão, deve o processo ter duração certa e breve, para evitar que se prolongue no tempo a angústia do acusado quanto ao seu futuro. Quando submetido a prisão cautelar, os danos pessoais ao indivíduo se multiplicam em todos os sentidos,

\footnotetext{
376 “(...) considerando uma situação extrema em que fosse cominada a pena de prisão perpétua, o critério da pena cominada ou da pena provável seria totalmente inadequado. A prisão e, por conseguinte, o processo, poderiam durar por toda um vida. O que dizer, então, caso fosse cominada a pena de morte? Fica evidente, pois, que para os delitos de maior gravidade, aos quais são cominadas penas abstratas bastante elevadas, deve-se buscar uma conjugação de critérios, com base nos fatos incontroversos emergentes no caso concreto, a fundamentarem a custódia e sua manutenção" (Cf. Aury Lopes Jr. e Gustavo Henrique Badaró, op. cit., p. 59).

${ }^{377}$ Ver item 1.2.
} 
trazendo prejuízo não só a ele como também a toda a sua família, que acabe sendo atingida indiretamente.

No caso Eckle, a Alemanha restou condenada por violação à garantia da razoável duração do processo, em sentença proferida em 15/07/1982. Hans Eckle e sua esposa tinham uma empresa de materiais de construção e, por dificuldades financeiras enfrentadas, passaram a conseguir empréstimos mediante fraude, com a prestação de diversas garantias hipotecárias sobre um mesmo bem, até o momento em que foram descobertos, quando deixaram de pagar diversos fornecedores. Nesse caso, o Tribunal entendeu que a pena aplicada na sentença condenatória deveria ser atenuada, em razão das dificuldades e inconvenientes pelos quais eles tiveram de passar após tantos anos de duração do processo, ainda que não estivessem presos. Reconheceu-se, assim, a possibilidade de aplicação de uma atenuante geral especial, diminuindo-se o quantum da reprimenda final aplicada ${ }^{378}$.

\subsubsection{Conduta processual do imputado}

O Tribunal europeu considerou a conduta do acusado como decisiva para a demora do processo pela primeira vez em 10/11/1969, no caso Stögmuller. Cidadão austríaco, foi acusado de estelionatos cometidos em operações financeiras e imobiliárias por meio de empresa da qual era o principal acionista. Foram 59 petições absolutamente incabíveis, em que a defesa recusava praticamente todas as testemunhas de acusação, suscitava conflitos de incompetência infundados, além de ter usado indevidamente o seu direito de recorrer, dentre outras providências. O tribunal entendeu que houve uma verdadeira "sabotagem do procedimento" pelo acusado, com o abuso de seus direitos processuais $^{379}$.

Posteriormente, em outras ocasiões, o tribunal europeu consignou que não se pode reprovar a atitude do acusado que tenha se utilizado de todas as faculdades processuais que lhe são asseguradas pelo direito interno ${ }^{380}$. No caso Neumeister, por

\footnotetext{
${ }^{378}$ Daniel R. Pastor, El plazo razonable..., cit., p. 143.

${ }^{379}$ Idem, p. 128.

${ }^{380}$ Idem, p. 148.
} 
exemplo, consignou de modo muito claro que "o acusado que se nega a colaborar com os órgãos da instrução ou que interpõe os recursos correspondentes se limita a fazer uso de seu direito e não pode ser sancionado por este motivo, a não ser que proceda com abuso ou com excesso." 381

Neste ponto, é de se notar uma diferença de entendimento relativamente ao processo civil, a respeito do qual a Corte européia exige uma "especial diligência" das partes, para que possam alegar violação à razoável duração do processo ${ }^{382}$. Por resguardar interesse privado das próprias partes, é exigido, no processo civil, uma diligência, uma colaboração intensa para o andamento do processo, cabendo a elas o impulso do processo. Já no processo penal, ao contrário, o impulso oficial é do juiz, não se podendo exigir uma participação ativa do acusado, em decorrência do princípio nemo tenetur se detegere.

\subsubsection{Complexidade da causa}

A complexidade da causa é um fator que pode justificar no caso concreto a extensão do procedimento para além do previsto. Muitas são as circunstâncias que podem provocar atrasos no desenrolar do processo, tais como o número de testemunhas a serem ouvidas, o número de acusados envolvidos, o tipo de crimes apurados, a necessidade de grande número de diligências, exames e perícias, a necessidade de cooperação internacional, etc.

No caso Neumeister, a duração do processo foi tida como razoável, pois justificável em razão da complexidade apresentada pela causa. A acusação de Neumeister versava sobre o cometimento de diversos crimes contra a ordem tributária, e a complexidade do caso repousou especialmente nos seguintes elementos: o grande volume de prova produzida (21 volumes, fora os apensos com a documentação relativa ao caso), o número de acusados envolvidos (22 ao todo), complexidade dos fatos, que pressupunham

\footnotetext{
${ }^{381}$ Plácido Fernandez-Viagas Bartolomé, El derecho a un proceso sin dilaciones indebidas, Madrid, Civitas, 1994, p. 92.

${ }^{382}$ Idem, p. 93.
} 
operações escalonadas de exportação e número de testemunhas (foram 102 dias de audiência), muitas deles residentes em outros países ${ }^{383}$.

Em Stögmuller, de igual modo, o grande número de complicadas operações financeiras fraudulentas realizadas pelo acusado (80, ao todo), elevado número de testemunhas (179) e de acusados (101), assim como o volume de documentos produzidos (mais de 20.000 páginas) e intrincada peça acusatória, com a narração de 48 delitos, foram fatores que provocaram a demora no procedimento, que durou cerca de 10 anos, período considerado razoável pelo Tribunal Europeu de Direitos Humanos.

\subsubsection{Maneira como a investigação foi conduzida e conduta das autoridades judiciais responsáveis pelo processo}

A conduta das autoridades responsáveis pela condução do processo ou, ainda, a forma como foi conduzida a investigação, é um dos critérios mais importantes a serem analisados.

Em diversas ocasiões, o Tribunal Europeu de Direitos Humanos assinalou que a forma como se portaram as autoridades responsáveis pela condução do processo deve preponderar sobre os demais critérios ${ }^{384}$. No caso Neumeister, por exemplo, a Corte européia assinalou que, por mais que os outros critérios indicassem para a violação da Convenção, apontando para uma duração irrazoável do processo e da prisão do acusado, a conduta das autoridades austríacas foi diligente, além de ter sido prejudicada pela falta de cooperação de autoridades estrangeiras em relação a diversas medidas de investigação que se faziam necessárias para o caso, não havendo como imputar ao Estado austríaco a responsabilidade pela violação.

É claro que, para um organismo internacional, a questão mais importante a ser analisada sempre deverá ser a forma como o Estado atuou num determinado caso, assim como as justificativas por ele trazidas para o alegado descumprimento de um tratado

\footnotetext{
${ }^{383}$ Daniel R. Pastor, El plazo razonable..., cit., p. 118.

${ }^{384}$ No caso König, o Tribunal assentou: "somos da opinião que é na condução do processo que devemos buscar a causa principal de sua duração”. Cf. Daniel R. Pastor, El plazo razonable..., cit., p. 138.
} 
internacional do qual seja parte, para definir se houve ou não violação a alguma regra da Convenção e se o Estado deve, ou não, ser considerado responsável pela sua violação.

Tanto é assim que, no procedimento de qualquer tribunal internacional, há espaço para que Estado-parte esclareça a forma como seu ordenamento interno se estrutura para propiciar a obediência às normas internacionais, além de justificar se houve ou não desídia na atuação das autoridades nacionais responsáveis pela condução do processo.

Assim, a transposição irrefletida desta orientação do Tribunal Europeu de Direitos Humanos para o âmbito doméstico, rechaçando a ocorrência de violação da garantia da razoável duração do processo mesmo quando o prazo de duração do processo reconhecidamente ultrapassa o razoável, simplesmente porque a conduta das autoridades foi diligente, pode trazer algumas distorções.

Tanto é válida essa observação que, mesmo no âmbito da Corte européia, houve votos dissidentes no caso Meumeister, refletindo o entendimento de que, por mais que os atrasos fossem do interesse da justiça e justificáveis do ponto de vista das autoridades responsáveis pela condução do caso, não é possível, num Estado Democrático de Direito, manter um homem por mais de sete anos na incerteza e angústia quanto ao seu futuro $^{385}$. Portanto, para os juízes Hölmbäck e Zekia, que sustentaram esse entendimento, os demais critérios deveriam preponderar, naquele caso, sobre o critério da conduta das autoridades na condução do processo.

Importante ressaltar, ainda, que, além da análise da forma com que o processo foi conduzido, este critério engloba a análise sobre eventual falha na organização do Poder Judiciário por parte do Estado. Em diversas ocasiões reforçou a idéia de que "o fator relativo ao 'comportamento das autoridades' compreende de maneira genérica a íntegra atuação dos poderes públicos" ${ }^{, 386}$, o que transportaria a responsabilidade pela demora não apenas ao Judiciário do Estado, mas também ao Executivo e ao Legislativo, que não foram capazes de tomar as medidas necessárias para superar os problemas estruturais que levaram à demora ${ }^{387}$.

\footnotetext{
${ }^{385}$ Idem, pp. 122-123.

${ }^{386}$ Plácido Fernandez-Viagas Bartolomé, op. cit., p. 99.

${ }^{387}$ Idem, p. 98.
} 
O Tribunal Europeu tem excluído a responsabilidade internacional do Estado nos casos em que há problemas episódicos, conjunturais, nos quais são adotadas medidas contingenciais para procurar solucionar o caso específico. "Porém, como adverte o TEDH, se esse estado de coisas se prolongar e assumir um caráter estrutural, não sendo os meios acima citados suficientes e não podendo a administração da justiça adotar outras medidas eficientes, o Estado responderá pelo retardamento do processo" ${ }^{\text {388 }}$.

No caso Martins Morcira, Portugal alegava que a demora no procedimento se dera em razão de deficiência do Instituto de Medicina Legal na apuração da sanidade mental do acusado, a despeito de diversos requerimentos do juiz do caso no sentido de imprimir maior celeridade ao exame. Entendia que a responsabilidade pela demora processual não poderia ser imputada a Portugal, já que as autoridades judiciais haviam se conduzido com a máxima diligência. Em resposta, o Tribunal consignou que "o Estado português, ao ratificar o Tratado, contraiu a obrigação de cumpri-lo e deve, em especial, garantir que assim o farão todas as suas distintas autoridades" ${ }^{389}$.

$\mathrm{Na}$ maioria dos casos examinados pelo Tribunal Europeu de Direitos Humanos, a atuação estatal considerada falha se manifestou na paralisação injustificada da atividade jurisdicional $^{390}$.

\subsubsection{Entendimento da Corte Interamericana de Direitos Humanos para a aferição do prazo razoável de duração da persecução penal}

É possível perceber uma verdadeira simetria entre os julgados do Tribunal Europeu de Direitos Humanos e da Corte Interamericana de Direitos Humanos no que se refere à análise da razoável duração do processo $^{391}$. Seguindo de perto a orientação européia, a Corte Interamericana também adotou os critérios do comportamento das partes,

\footnotetext{
${ }^{388}$ Aury Lopes Jr. e Gustavo Henrique Badaró, op. cit., p. 70.

${ }^{389}$ Plácido Fernandez-Viagas Bartolomé, op. cit., p. 100.

${ }^{390}$ Idem, p. 98.

${ }^{391}$ Cf. Daniel Pastor, El plazo razonable..., cit., p. 205.
} 
da complexidade da causa e da conduta das autoridades responsáveis pela condução do processo.

Em diversas ocasiões, a Corte Interamericana repisou o entendimento de que "para examinar se em um processo o prazo foi ou não razoável, segundo os termos do artigo 8.1 da Convenção, a Corte levará em consideração três elementos: a) complexidade do assunto; b) atividade das partes; c) conduta das autoridades judiciais" ${ }^{392}$.

O juiz Sérgio Garcia Ramírez, em seu voto proferido no caso Valle Jaramillo $^{393}$, apoiou a adoção de um quarto critério para aferição da razoabilidade da duração do processo, que corresponde aos efeitos pessoais trazidos ao acusado pela excessiva duração do processo, critério que já havia sido proposto pela Comissão européia e não acatado pelo Tribunal Europeu de Direitos Humanos. Para ele, "como possível quarto elemento a ser considerado para a estimativa do prazo razoável, indico o que denominei de 'afetação atual que o procedimento implica para os direitos e deveres - isto é, a situação jurídica - do indivíduo"”. E ainda, neste mesmo sentido: "Se o passar do tempo incide de maneira relevante na situação jurídica do indivíduo, resultará necessário que o procedimento corra com mais diligência a fim de que o caso se resolva em um tempo breve".

A análise dos efeitos pessoais suportados pelo acusado se fez, por exemplo, no caso López Alvarez, preso cautelarmente durante seis anos em razão da suposta prática do crime de tráfico ilícito de entorpecentes. Após seis anos de duração da prisão cautelar, o acusado foi absolvido das acusações. A Corte entendeu que deveriam ser analisados naquele caso os prejuízos causados pela prisão cautelar decretada contra o acusado. Asseverou-se, na sentença, que "o Estado presumiu sua culpabilidade e o tratou como culpado pelo delito, em contrariedade ao princípio da presunção de inocência"394 ${ }^{\text {. Diante }}$ dos sofrimentos causados ao acusado e à sua família, a Corte resolveu condenar Honduras a pagar uma quantia em dinheiro a título de indenização pelos danos morais suportados.

\footnotetext{
392 Cf. caso García Asto y Ramírez Rojas, sentença de 28 de novembro de 2005. No mesmo sentido: López Alvarez, sentença proferida em $1^{\circ}$ de fevereiro de 2006; Tibi, sentença de 7 de setembro de 2004; Comerciantes vs. Colômbia, sentença de 5 de julho de 2004; Valle Jaramillo y otros vs. Colombia, sentença de novembro de 2008 .

${ }^{393}$ Sentença de 21 de junho de 2002.

${ }^{394}$ Sentença proferida em $1^{\circ}$ de fevereiro de 2006.
} 
O mesmo se deu no caso Caesar, cuja sentença foi proferida em 11 de março de 2005. Trinidad e Tobago ratificou a Convenção Americana de Direitos Humanos em 28 de maio de 1991, denunciando-a, alguns anos depois, em 26 de maio de 1999. A violação aos direitos fundamentais de Caesar teria ocorrido neste ínterim, em que ainda vigia a Convenção, do ponto de vista internacional, em relação a Trinidad e Tobago, o que possibilitou a sua condenação perante a Corte Interamericana de Direitos Humanos ${ }^{395}$.

Caesar foi condenado a uma pena corporal chamada gato de nueve colas, em que o indivíduo é atingido por quinze chibatadas com esta espécie de chicote com nove filamentos. Durante o processo, ficou preso por mais de 6 anos em condições muito precárias, sem colchão e sem fossa sanitária, com outros cinco detentos numa mesma cela, o que debilitou consideravelmente a sua saúde. Após a condenação, mesmo em situações péssimas de saúde, foi submetido à pena corporal em questão, aplicada em condições bastante humilhantes, completamente nu e preso por um estrutura de metal, em posição de “águia estendida". Trinidad e Tobago foi condenada a indenizar a vítima, adotar as medidas legislativas para banir as penas corporais e tomar as providências necessárias para adequar as suas carceragens às normas internacionais de direitos humanos.

No que diz respeito à garantia da razoável duração do processo, neste caso, a Corte considerou que a prisão se prolongou além do razoável durante o curso do processo e que houve, ainda, demora na execução da pena após a condenação, o que trouxe inúmeros prejuízos de ordem material e moral ao acusado, a serem indenizados pelo Estado.

A par destas considerações, passar-se-á à análise de alguns casos julgados pela Corte Interamericana de Direitos Humanos que demonstram a forma semelhante como têm sido aplicados os três critérios importados do tribunal europeu, complexidade da causa, atividade das partes e condutas das autoridades judiciais, no contexto do continente americano.

\footnotetext{
395 "Trinidad y Tobago exercitou seu direito soberano de denunciar e se retirar da Convenção. Todavia, nenhum Estado que tenha se comprometido a um tratado internacional pode de boa fé se recusar a cumprir as obrigações a que de modo inequívoco se obrigou a honrar durante o prazo de validade do tratado. Isso seria uma burla para o Direito Internacional e, em caso de tratados de direitos humanos, minaria um regime de preocupação internacional pelo ser humano enquanto indivíduo que remonta nada menos que à Declaração Universal de Direitos Humanos". Sentença de 11 de março de 2005.
} 


\subsubsection{Complexidade da causa}

Um caso de razoável complexidade apreciado pela Corte Interamericana de Direitos Humanos foi o do seqüestro das irmãs Serrano Cruz, em El Salvador. As duas crianças, Ernestina e Erlinda, de 7 e 3 anos de idade, respectivamente, foram capturadas por militares integrantes do Batalhão de El Salvador durante uma operação militar. Os pais de Ernestina e Erlinda conseguiram fugir do cerco militar, composto por 14 mil militares, mas as duas meninas acabaram sendo levadas. As meninas foram vistas, pela última vez, 21 anos atrás, quando eram transportadas em um helicóptero das Forças Armas de El Salvador, e, desde então, os pais não tiveram mais notícias de seu paradeiro.

Para a Corte, o caso era claramente muito complexo, pois envolvia dificuldades para a identificação dos responsáveis, necessidade de oitiva de muitas testemunhas, necessidade de diligências, entre outros fatores dificultadores. Mesmo assim, a despeito da grande complexidade do caso, a Corte deu preponderância aos outros critérios, que apontavam para a responsabilidade internacional de El Salvador, por violação ao direito razoável duração do processo.

O voto proferido pelo juiz Sérgio García Ramírez em 27 de novembro de 2008 no caso Valle Jaramillo e outro versus Colômbia traz um resumo de alguns fatores que são levados em consideração pela Corte Interamericana para avaliar a complexidade de uma causa: problemas sérios na aplicação jurídica ou na qualificação jurídica, pareceres desencontrados, jurisprudência não consolidada, legislação incerta, número de relações jurídicas envolvidas no caso e número de participantes no processo.

\subsubsection{Comportamento das partes}

No que se refere ao comportamento das partes, a Corte Interamericana seguiu os passos da Corte Européia, distinguindo o exercício legítimo da ampla defesa do abuso das faculdades processuais, quando esta busca a obstaculização deliberada do procedimento. 
No caso Garcés Valladares, a Comissão fez uma importante distinção: uma coisa é o direito do acusado em se servir dos mecanismos processuais à sua disposição ou de não colaborar com o processo, outra coisa diversa é a obstaculização deliberada ${ }^{396}$. Neste mesmo caso, a Comissão ressaltou que é preciso haver uma intenção, um propósito por parte do acusado de obstruir o desenvolvimento do processo, não se podendo imputar a demora ao acusado se não houver elementos seguros de que a defesa agiu com abuso proposital no uso de seus direitos processuais ${ }^{397}$.

No caso Valle Jaramillo e outro versus Colômbia, julgado em 27 de novembro de 2008, a Corte Interamericana voltou a fazer a mesma advertência: "não se pode exigir que o indivíduo prescinda de atos de defesa em nome da celeridade, ou a título de uma suposta racionalidade do procedimento, de acordo com os critérios de terceiros, alheios à causa. $\mathrm{O}$ Tribunal deve distinguir com prudência entre as ações e omissões da parte que têm como objetivo a defesa - bem ou mal informada - e aquelas que servem apenas à demora. Não de pode transportar ao acusado que está defendendo a responsabilidade pelas demoras no procedimento e, em conseqüência, pela violação do prazo razoável”.

\subsubsection{Conduta das autoridades judiciais}

A respeito da conduta das autoridades judiciais responsáveis pela condução do processo, destaca-se, no âmbito da Corte Interamericana de Direitos Humanos, o voto do juiz Sérgio García Ramírez no caso López Álvarez ${ }^{398}$, no qual afirma categoricamente que "o excesso de trabalho não pode justificar a inobservância do prazo razoável, que não é uma equação nacional entre o volume de litígios e o número de tribunais, mas uma referência individual para o caso concreto".

Interessante também a distinção feita no caso Valle Jaramillo e outro versus Colômbia, julgado em 27 de novembro de 2008, entre a "atividade exercida com reflexão e cautela justificáveis" e a "atividade desempenhada com excessiva parcimônia e lentidão, com uso de excessivos ritualismos".

\footnotetext{
${ }^{396}$ Daniel R. Pastor, El plazo razonable..., cit., p. 220.

${ }^{397}$ Idem, ibidem.

${ }^{398}$ Sentença proferida em $1^{\circ}$ de fevereiro de 2006.
} 
Neste caso, Jesús Maria Valle Jaramillo, um importante e conhecido defensor de direitos humanos na Colômbia, foi sumariamente executado por grupos paramilitares supostamente ligados ao governo. Jaramillo denunciava, sistematicamente, o que considerava "desmandos" realizados por este grupos no município de Ituango. Assim como ele, vários outros defensores de direitos humanos foram exterminados na mesma região. A Corte entendeu que houve negligência por parte do Estado na apuração da responsabilidade criminal dos assassinos, que não conduziu a apuração criminal com suficiente diligência. A própria Colômbia chegou a reconhecer sua responsabilidade no caso, por não conseguir combater estes grupos armados ilegais no país.

Ressalta-se, ainda, dentre os julgados da Corte Interamericana a respeito da conduta das autoridades judiciais na condução do processo, o caso das irmãs Serrano $\mathrm{Cruz}^{399}$, em que se considerou ter havido não apenas uma negligência na condução do caso, mas uma verdadeira obstaculização, inclusive com a adulteração de provas e condução parcial das investigações. Para a Corte, "as atuações tanto dos investigadores como do juiz de primeira instância colocam em sérias dúvidas a imparcialidade da investigação, assim como da veracidade das provas colhidas. Em primeiro lugar, há indícios de que a senhora Maria Esperanza foi coagida a mudar o seu último depoimento. Em segundo lugar, a parcialidade do processo demonstra que o objetivo final da investigação se converteu em defender o Estado perante a Corte e não determinar e sancionar os responsáveis".

Foram ainda considerados sinais desta atitude deletéria na apuração do fato os seguintes fatores: transcurso de longos prazos de inatividade, em que não foi realizada diligência, arquivamento do inquérito por mais de um ano e demora injustificada para a realização de atos corriqueiros e sem nenhuma complexidade como a expedição de ofícios e realização de despachos de mero expediente. Ao todo, foram 8 anos e 10 meses de investigação e, até o momento em que o caso foi submetido à apreciação da Corte, não havia sido formulada a peça acusatória contra os prováveis responsáveis.

\footnotetext{
${ }^{399}$ Ver mais a respeito do caso no item 6.1.2.1.
} 


\title{
6.1.3. Entendimento dos tribunais brasileiros para a aferição do prazo razoável de duração da persecução penal
}

\begin{abstract}
A jurisprudência brasileira, aos poucos, passou a adotar os três critérios consagrados internacionalmente, analisando, em cada caso concreto, se houve ou não negligência ou deficiência na condução do processo por parte das autoridades judiciais, se a defesa ou o comportamento do acusado deram causa à demora na tramitação, assim como se o caso apresenta dificuldades ou complexidade que demandem maior tempo para análise.
\end{abstract}

\subsubsection{Comportamento das partes}

O critério do comportamento das partes leva em consideração a delicada equação entre o exercício legítimo de um direito e o seu uso indevido. Tanto defesa como acusação têm direitos processuais e, sob a ótica da paridade de armas, podem exercê-los em seu grau máximo, utilizando-se de todos os mecanismos legais que lhes estiver ao alcance para o bom desempenho de seu papel no processo. A grande problemática repousa no momento em que uma das partes passa a extrapolar o uso de seus direitos, utilizando-os de maneira apenas a buscar um efeito deletério sobre o procedimento.

No que se refere à conduta da defesa ou comportamento do acusado, a interpretação sobre a legitimidade, ou não, de sua atuação deve ser feita com base em dados bastante objetivos, já que o exercício legítimo da defesa não pode resultar em prejuízo para o acusado. $\mathrm{O}$ exercício de um direito não pode trazer qualquer sanção a quem o exerce $^{400}$.

A realização de diligências do interesse da defesa, a insistência na produção de provas relevantes para o processo, assim como o exercício dos recursos postos à disposição pela sistemática processual, não podem ser usados como fatores de justificação da demora do procedimento, dado que o direito à razoável duração do processo deve

400 “(...) consistiria inominado absurdo entender-se que o exercício de um direito, expresso na Lei das Leis como fundamental do indivíduo, possa acarretar-lhe qualquer desvantagem" (Rogério Lauria Tucci, Direitos e garantias..., cit., p. 370). 
contemplar também o direito à ampla defesa, e ao Estado cabe propiciar meios para que o processo seja desenvolvido num prazo razoável.

Além disso, também não se pode exigir do acusado qualquer tipo de colaboração ativa para que o procedimento de desenvolva de maneira célere. $\mathrm{O}$ acusado tem o direito de se quedar inerte, não colaborando na produção de provas contra si mesmo, por força da garantia do nemo tenetur se detegere ${ }^{401}$.

Igualmente, não se pode atribuir a culpa pela demora para a conclusão do processo em virtude de anulação de algum ato processual, pois ao Judiciário é imputada a responsabilidade pela regularidade dos atos processuais ${ }^{402}$.

Diante de tal quadro, é de se concluir que a conduta da defesa apenas pode ser levada em consideração, para a análise sobre a demora do processo, se manifestamente abusiva, claramente protelatória. Presume-se legítima a atuação da defesa, como resultado da garantia da ampla defesa ${ }^{403}$. Por esta razão, eventual má-fé no comportamento desta não pode ser extraída com base em um ato isolado. A atuação da defesa precisa ser analisada em seu todo, de molde a se verifica se houve, ou não, o intuito deliberado de atrapalhar o regular desenvolvimento do procedimento no caso concreto.

Como leciona BADARÓ ${ }^{404}$, a Súmula $\mathrm{n}^{\mathrm{o}} 64$ do Superior Tribunal de Justiça, segundo a qual "não constitui constrangimento ilegal o excesso de prazo na instrução, provocado pela defesa", criada no intuito de reprimir delongas provocadas dolosamente pela defesa, sofreu ao longo do tempo um desvirtuamento, levando ao

\footnotetext{
401 "Então, sublinhe-se: o imputado não tem nenhum dever de contribuir ou colaborar para o célere trâmite do processo. Nenhum prejuízo poderá advir-lhe da inércia processual, pois protegido pelo direito de silêncio e de não produzir prova contra si mesmo." (Aury Lopes Jr. e Gustavo Henrique Badaró, op. cit., p. 64). Em sentido inverso, destacam-se alguns julgados, entendendo que "a demora na formação da culpa está plenamente justificada pela complexidade dos fatos que estão sendo apurados, bem como pelo fato de que o paciente em nada colaborou com as investigações, invocando seu direito de permanecer calado, redobrando o trabalho policial na busca do esclarecimento dos fatos" (TRF 4a Região, HC 2007.04.00.042131-0, Sétima Turma, Rel. Vera Lúcia Feil Ponciano, j. 15/01/2008, DJ de 23/01/2008); TRF 4a Região, HC 2008.04.00.000136-2, Sétima Turma, Rel. Vera Lúcia Feil Ponciano, j. 29/01/2008, DJ de 14/02/2008.

${ }^{402}$ TJMG, HC 1.0000.05.425063-4, Rel. Márcia Milanez, j. 20/09/2005, DJ de 27/09/2005.

${ }^{403}$ Aury Lopes Jr. e Gustavo Henrique Badaró, op. cit., p. 65: "A regra é presumirem-se legítimas todas as atuações da defesa, pois essa presunção de legitimidade brota do direito fundamental à ampla defesa".

${ }^{404}$ Gustavo Henrique Righi Ivahy Badaró, op. cit., p. 34. O autor tece, ainda a respeito da interpretação que se desenvolveu a partir da Súmula $n^{\circ} 64$ do Superior Tribunal de Justiça, a seguinte crítica: "Não será de se estranhar que, se esta involução não for interrompida, surja uma súmula que diga que 'realizado o interrogatório, fica superada a alegação de constrangimento ilegal por excesso de prazo"”.
} 
entendimento de que o termo final para se alegar o constrangimento ilegal por excesso de prazo da prisão é o término da oitiva das testemunhas de acusação ${ }^{405}$.

Em muitos julgados, colhe-se o entendimento de que o requerimento de diligências $^{406}$, a expedição de carta precatória para a oitiva de testemunhas ${ }^{407}$ ou a interposição de recursos pela defesa ${ }^{408}$, afastaria a alegação de excesso de prazo. "Aqui a defesa é vista como um obstáculo ao andamento processual célere e o Estado - cuja jurisdição imputa a ela uma demora que é sua, pois todos os atos processuais são oficiais. Não há diligências que devam ser produzidas pela parte, mas todas pelo Estado. Ora, se a diligência é procrastinatória (e muitas vezes pode ser este o caso), deve a produção daquele meio de prova não ser admitida quando requerida. Se requerida e admitida, cumpre ao Estado, e não à parte, efetivá-la. Neste diapasão a demora não é causada pela defesa, mas pela ineficiência estatal" ${ }^{\prime 409}$.

Tanto à acusação quanto à defesa é dado contribuir positivamente para a formação do convencimento judicial com a introdução de provas sobre o fato. De acordo com a lição de GOMES FILHO, existe "um verdadeiro direito subjetivo à introdução do

\footnotetext{
${ }^{405}$ Nesse sentido, os seguintes, dentre muitos, julgados do Superior Tribunal de Justiça: HC 52733, Quinta Turma, Rel. Min. Laurita Vaz, j. 06/06/2006, DJ de 01/08/2006; HC 28733, Quinta Turma, Rel. Min. Jorge Scartezzini, j. 02/09/2003, DJ de 01/12/2003. Os Tribunais de diversos Estados seguiram esta mesma orientação: TJSP, HC 990080921037, $4{ }^{a}$ Câmara, Rel. Marco Antônio Cogan, j. 02/12/2008, DJ de 08/01/2009.
}

${ }^{406}$ Nesse sentido: STJ, HC 88676, Quinta Turma, Rel. Min. Arnaldo Esteves Lima, j. 08/11/2007, DJ de
$07 / 02 / 2008$; STJ, STJ, HC 40019, Quinta Turma, Rel. Min. Laurita Vaz, j. 01/03/2005, DJ de 28/03/2005;
STJ, HC 32299, Quinta Turma, Rel. Min. Jorge Scartezzini, j. 01/04/2004, DJ de 24/05/2004; STJ, HC
29141, Quinta Turma, Rel. Min. Jorge Scartezzini, j. 14/10/2003, DJ de 19/12/2003. Em idêntico sentido,
ver, ainda: TRF $1^{\text {a }}$ Região, HC 2008.01.00.010769-8/MT, Quarta Turma, Rel. Des. Fed. Mário César
Ribeiro, j. 19/05/2008, DJ de 25/07/2008; TRF 1a Região, HC 2004.01.00.003605-4/AM, Terceira Turma,
Rel. Des. Fed. Olindo Menezes, j. 16/03/2004, DJ de 23/04/2004; TRF 1 ${ }^{a}$ Região, HC 2003.01.00.033924-
5/AM, Rel. Des. Fed. Olindo Menezes, j. 25/11/2003, DJ de 12/12/2003; TJRJ, Ap. Crim. 2008.050.05161,
Primeira Câmara, Rel. Des. Marcus Basílio, j. 11/12/2008.

${ }^{407}$ No sentido de que a necessidade de expedição de carta precatória para a oitiva de testemunha arrolada pela defesa afasta a alegação de excesso prazo, ver: TJMG, HC 1.0000.07.459765-9, Rel. Pedro Vergara, j. 04/09/2007, DJ de 22/09/2007; TRF $1^{\text {a }}$ Região, HC 2008.01.00.024140-1/RO, Terceira Turma, Rel. Juiz Federal Reynaldo Soares da Fonseca, j. 18/06/2008, DJ de 27/06/2008; TRF $1^{\text {a }}$ Região, HC 2008.01.00.018291-5/RO, Terceira Turma, Rel. Des. Fed. Assusete Magalhães, j. 03/06/2008, DJ de $13 / 06 / 2008$.

${ }^{408}$ Ver, por exemplo: STJ, HC 27746, Quina Turma, Rel. Min. José Arnaldo da Fonseca, j. 16/09/2003, DJ de 13/10/2003. Até mesmo no âmbito do Supremo Tribunal Federal é possível encontrar o mesmo pensamento: HC 92719/ES, Segunda Turma, Rel. Min. Joaquim Barbosa, j. 24/06/2008, DJ de 19/09/2008 e HC 87189/RS, Primeira Turma, Rel. p/ acórdão Min. Cezar Peluso, j. 02/05/2006, DJ de 06/10/2006.

${ }^{409}$ Fauzi Hassan Choukr e Kai Ambos, Temas de Direito e Processo Penal, Rio de Janeiro, Lumen Juris, 2004, p. 48. 
material probatório no processo, bem como de participação em todas as fases do procedimento respectivo; direito subjetivo que possui a mesma natureza constitucional e o mesmo fundamento dos direito de ação e defesa: o direito de ser ouvido em juízo não significa apenas poder apresentar ao órgão jurisdicional as próprias pretensões, mas também inclui a garantia do exercício de todos os poderes para influir positivamente sobre o convencimento do juiz" ${ }^{410}$. Eventual contribuição da defesa para a delonga do processo deve ser analisada, assim, sob a perspectiva da ampla defesa e do contraditório, sem que lhe seja tolhida a possibilidade de produzir prova em seu favor.

Como contraponto a tais críticas por parte da doutrina, percebe-se que existe uma tendência, ainda não consolidada, de mudança de enfoque dado à participação da defesa para o excesso de prazo no processo. "De uma visão que considerava que a colaboração da defesa para a extensão temporal do trâmite procedimental a qualquer título impedia a alegação de excesso de prazo, passou-se gradativamente a uma visão mais constitucional, que leva em consideração a forma como a defesa atuou no processo, se condizente com o exercício da ampla defesa e do contraditório ou se voltada muitas vezes ao tumulto e procrastinação do feito com a exigência de diligências irrelevantes ou incabíveis" ${ }^{411}$.

Como a atuação normal da defesa não pode ser contabilizada em prejuízo do acusado, apenas a utilização de artifícios que extrapolam o exercício da ampla defesa, voltados deliberadamente à sabotagem do procedimento, forçando a sua delonga, é que pode ser avaliado negativamente no que se refere ao alegado excesso de prazo. Alguns exemplos desse tipo de atuação ilegítima podem ser citados, da análise de julgados de diferentes tribunais brasileiros: pedido constante de adiamento de atos processuais sem qualquer justificativa ${ }^{412}$, o não comparecimento injustificado do advogado em audiência $^{413}$, a reiteração constante de pedidos de liberdade provisória ou revogação de

\footnotetext{
${ }^{410}$ Antonio Magalhães Gomes Filho, Direito à prova no processo penal, São Paulo, Revista dos Tribunais, 1997, p. 84.

${ }^{411}$ Cf. Maria Thereza Rocha de Assis Moura e Thaís Aroca Datcho Lacava, op. cit., p. 414.

${ }^{412}$ Nesse sentido: STJ, HC 85295, Quinta Turma, Rel. Min. Napoleão Nunes Maia Filho, j. 06/09/2007, DJ de 24/09/2007, e STJ, HC 60395, Quinta Turma, Rel. Min. Feliz Fischer, j. 24/10/2006, DJ de 26/02/2007.

413 TJRJ, HC 2008.059.03533, Segunda Câmara, Rel. Des. José Muinos Pineiro Filho, j. 16/09/2008.
} 
prisão preventiva sem qualquer alteração fática ${ }^{414}$, constante renúncia ou substituição de defensores constituídos nos autos ${ }^{415}$, ausência reiterada das testemunhas de defesa às audiências designadas $^{416}$, demora na apresentação de defesa prévia $^{417}$, necessidade de nomeação de defensor ad hoc para a apresentação de alegações finais ${ }^{418}$, inércia na apresentação de quesitos para incidente de insanidade mental ${ }^{419}$, fornecimento de endereço equivocado e constante substituição de testemunhas ${ }^{420}$, demora na restituição de autos com carga para a defesa ${ }^{421}$ e requerimento de diligências e providências anômalas ${ }^{422}$.

Além disso, a conduta da defesa, ainda que dirigida no sentido de protelar o processo, deve ser sempre analisada em conjunto com a atuação estatal. Se a pronta atuação estatal poderia ter minimizado significativamente o atraso causado pela defesa mas, ao contrário, acabou por potencializá-lo, não pode ser imputada apenas a esta a culpa

${ }^{414}$ Trata-se aqui da reiteração de pedidos de liberdade provisória ou de revogação preventiva sem qualquer alteração fática, quando já são conhecidos os motivos invocados pela autoridade judicial para a manutenção da prisão, e que apenas retardam a marcha processual, gastando-se tempo desnecessário com a sua apreciação. Nesse sentido: STJ, RHC 21311, Quinta Turma, Rel. Min. Arnaldo Esteves Lima, j. 09/08/2007, DJ de 10/09/2007.

${ }^{415}$ STJ, HC 49474, Quinta Turma, Rel. Min. Laurita Vaz, j. 12/12/2006, DJ de 12/02/2007; TRF $3^{\text {a }}$ Região, HC 2007.03.00.103246-3, Segunda Turma, Rel. Juiz Cotrim Guimarães, j. 15/04/2008, DJ de 25/04/2008; TJRJ, HC 2008.059.07763, Quinta Câmara, Rel. Des. Geraldo Prado, j. 11/12/2008.

${ }^{416}$ Nesse sentido: TRF $1^{\text {a }}$ Região, HC 2008.01.00.005375-4/MA, Terceira Turma, Rel. Des. Fed. Olindo Menezes, j. 03/03/2008, DJ de 04/04/2008.

${ }^{417}$ TRF $3^{\text {a }}$ Região, HC 2007.03.00.103246-3, Segunda Turma, Rel. Juiz Cotrim Guimarães, j. 15/04/2008, DJ de 25/04/2008; TJRJ, HC 2008.059.06210, Quarta Câmara, Rel. Des. Gizelda Leitão Teixeira, j. 30/09/2008; TJRS, HC 70027389527, Rel. Mário Rocha Filho, j. 27/11/2008, DJ de 03/12/2008; TJRS, HC 70026706598, Rel. Fabianne Breton Baisch, j. 12/11/2008, DJ de 29/12/2008.

${ }^{418}$ TRF3 $^{a}$ Região, HC 2007.03.00.101888-0, Quinta Turma, Rel. Juíza Ramza Tartuce, j. 11/02/2008, DJ de 26/02/2008; TRF $3^{\text {a }}$ Região, HC 2007.03.00.103858-1, Quinta Turma, Rel. Juíza Ramza Tartuce, j. $11 / 02 / 2008$, DJ de 26/02/2008.

${ }^{419}$ TJRJ, HC 2008.059.05959, Quinta Câmara, Rel. Des. Rosa Helena Guita, j. 09/10/2008.

${ }^{420}$ TRJ, HC 2008.059.06920, Quarta Câmara, Rel. Des. Gizelda Leitão Teixeira, j. 07/10/2008; TJRJ, HC 2008.059.054459, Primeira Câmara Criminal, Rel. Des. Carlos Augusto Borges, j. 18/09/2008.

${ }^{421}$ TJRS, HC 70022112288, Primeira Câmara, Rel. Marco Antônio Ribeiro de Oliveira, j. 28/11/2007, DJ de 23/01/2008 (“o processo esteve em carga com o advogado do réu de 04/01/07 a 26/04/07, tendo sido, inclusive, expedido mandado de busca e apreensão dos autos, o que contribui ainda mais para o retardamento da prestação jurisdicional"). No mesmo sentido: TJRJ, HC 2008.059.07562, Quinta Câmara, Rel. Des. Geraldo Prado, j. 13/11/2008.

${ }^{422}$ Cf. STJ, HC 49474, Quinta Turma, Rel. Min. Laurita Vaz, j. 12/12/2006, DJ de 12/02/2007. Neste habeas corpus, é noticiado o requerimento, por parte da defesa, de providências absolutamente descabidas e anômalas, que apenas causaram tumulto no processo, como o pedido de comunicação ao réu preso acerca da habilitação do advogado como seu defensor nos autos, providências estas que poderiam perfeitamente ser realizadas fora dos autos pela própria defesa, pois se trata de relação entre cliente e advogado, não se podendo esperar do Judiciário que utilize a máquina estatal para fazer esse tipo de diligência. 
pela demora ${ }^{423}$. No julgamento do habeas corpus $n^{\circ}$ 93786/ES, o Supremo Tribunal Federal considerou que, mesmo no caso de ter a defesa insistido na oitiva de testemunhas residentes em outras Comarcas, não se justifica a falta de realização do ato por mais de cinco anos, o que configura a inércia do Poder Judiciário ${ }^{424}$.

O próprio acusado pode, por um determinado comportamento seu, interferir negativamente na marcha processual. O direito que ele possui de não colaborar com a Justiça não pode ser extrapolado ao ponto de prejudicar o seu andamento, por meio de uma conduta ativa dirigida nesse sentido. Um exemplo comumente encontrado na jurisprudência brasileira é o do acusado que dificulta sua identificação, fornecendo nome falso durante o interrogatório, dando causa, assim, a diligências posteriores necessárias para corrigir o engano provocado ${ }^{425}$. O fornecimento de documentos falsos ${ }^{426}$, de igual modo, assim como o não comparecimento injustificado do réu solto às audiências ${ }^{427}$, pode causar transtornos ao normal desenrolar do procedimento, colaborando para a demora na conclusão da instrução.

\subsubsection{Complexidade da causa}

A complexidade da causa é, sem dúvida, um dos principais fatores que provocam dilação no procedimento.

\footnotetext{
${ }^{423}$ Conferir os seguintes casos julgados pelo Superior Tribunal de Justiça, em que a atuação da defesa foi analisada em confronto com a atuação estatal, chegando-se à conclusão de que a culpa da defesa foi de menor importância se comparada à ineficiência da atuação do próprio Estado: Sexta Turma, HC 94783, Rel. Min. Maria Thereza de Assis Moura,j. 10/06/2008, DJ de 30/06/2008, e Sexta Turma, HC 81996, Rel. Min. Maria Thereza de Assis Moura, j. 29/11/2007, DJ de 17/12/2007. No mesmo sentido, destaca-se, ainda: TJRJ, HC 2007.059.02532, Sétima Câmara, Rel. Des. Geraldo Prado, j. 29/05/2007.

${ }^{424}$ Primeira Turma, Rel. Carlos Britto, j. 17/06/2008, DJ de 31/10/2008.

${ }^{425}$ Nesse sentido, são diversos os julgados: TRF $1^{\text {a }}$ Região, HC 2008.01.00.049703-5/MG, Terceira Turma, Rel. Des. Fed. Cândido Ribeiro, j. 21/10/2008, DJ de 31/10/2008; TRF 1ª Região, HC 2004.01.00.0467090/GO, Quarta Turma, Rel. Des. Fed. Carlos Olavo, j. 23/11/2004, DJ de 13/12/2004.

426 Reconhecendo que o atraso causado pela apresentação de documentação falsa pelo acusado afasta a alegação de excesso de prazo pela defesa, destacam-se os seguintes julgados: TRF $1^{\mathrm{a}}$ Região, HC 2007.01.00.055713-0/MG, Quarta Turma, Rel. Des. Fed. Ítalo Fioravanti Sabo Mendes, j. 29/01/2008, DJ de $21 / 02 / 2008$.

${ }^{427} \mathrm{O}$ não comparecimento injustificado acusado à audiência, levando à sua remarcação e conseqüente atraso na conclusão da instrução, deve ser levado em consideração para a aferição do excesso de prazo, segundo o seguinte julgado: TRF $1^{\text {a }}$ Região, HC 2007.01.00.012958-3/AM, Terceira Turma, Rel. Des. Fed. Olindo Menezes, j. 07/05/2007, DJ de 18/05/2007.
} 
Como bem consignado por Aury Lopes Júnior e Gustavo Henrique Badaró, "um problema de retardamento ou de dilação processual, no que diz respeito à condução do processo, pode ter sua origem tanto na deficiente direção da autoridade judiciária, como na carência e meios ou adequada organização dos Tribunais dos Estados. Nesta última hipótese, porém, a responsabilidade passaria do Poder Judiciário para o Poder Executivo" 428 .

A responsabilidade pela demora, decorrente tanto da má condução do processo quanto da falha de estrutura do próprio Poder Judiciário, é do Estado. Portanto, o acusado não deve suportar os prejuízos de um processo demorado com base em argumentos tais como excesso de trabalho, falta de funcionários, estrutura deficiente nos tribunais, etc.

Ademais, em se tratando de violação a direitos humanos, é sempre bom recordar que por mais que os Estados tenham se esforçado para evitá-la, não se pode desprezar o resultado final, impondo-se o reconhecimento da violação ocorrida. PASTOR rechaça completamente a possibilidade de eximir o Estado de responsabilidade pela violação a direitos e garantias fundamentais sob este argumento: “os desesperados, porém inúteis, esforços de um médico para salvar a vida de seu paciente merecem as maiores honras, mas não servem em nada para impedir sua morte quando esta é inevitável”429.

A complexidade pode ser de ordem objetiva ou subjetiva. A complexidade objetiva é aquela que diz respeito às dificuldades relativas ao objeto do processo, ou seja, ao tipo de crime ou dos fatos submetidos à apreciação da Justiça, enquanto a complexidade subjetiva refere-se aos sujeitos envolvidos no processo, especialmente o número de acusados, vítimas ou testemunhas.

A natureza do crime pode ser considerada como um indicativo de complexidade, já que interfere na escolha do tipo do procedimento a ser adotado para a sua apuração, que pode ser mais ou menos amplo e, assim, demandar mais ou menos tempo para a sua conclusão. Isto é o que acontece, por exemplo, com os crimes de menor potencial ofensivo, que, em regra, não necessitam de muitas fases procedimentais para o seu julgamento, ou com os crimes dolosos contra vida que, por outro lado, demandam um procedimento mais amplo e, portanto, mais demorado.

\footnotetext{
${ }^{428}$ Aury Lopes Jr. e Gustavo Henrique Badaró, op. cit., p. 69.

${ }^{429}$ Daniel R. Pastor, El plazo razonable..., cit., p. 141.
} 
Alguns tipos penais também demandam maiores dificuldades para a sua apuração, trazendo maior complexidade ao procedimento. Alguns exemplos a serem citados são os crimes contra o sistema financeiro, crimes econômicos e falimentares, que geralmente envolvem complexas perícias contábeis ${ }^{430}$ e os crimes de quadrilha ou bando, ou envolvendo organizações criminosas ${ }^{431}$, que geralmente envolvem intrincadas relações entre os acusados, muitas vezes demandando a necessidade de interceptação telefônica e a necessidade de posterior degravação, assim como a determinação de prisões cautelares, buscas e apreensões, seqüestro, arresto, etc.

Todavia, não é possível fazer generalizações pois, mesmo um processo que, em tese, pelo tipo de crime apurado, deveria ser complexo, pode se mostrar concretamente fácil de ser resolvido, com poucas testemunhas, perícias corriqueiras e desnecessidade de dilações procedimentais ${ }^{432}$. Por outro lado, um crime de menor potencial ofensivo, em regra mais simples de ser perseguido, pode se revelar demasiado complexo, tanto que há a previsão na Lei 9.099/95 de remessa do feito ao juízo comum para que siga um procedimento mais amplo nesta hipótese ${ }^{433}$.

Por esta razão, a mera soma dos prazos legais previstos para cada ato do procedimento, critério jurisprudencial bastante utilizado para a análise do excesso de prazo para a prisão, não atende satisfatoriamente a necessidade de estipular-se um prazo máximo

\footnotetext{
${ }^{430}$ Nesse sentido, ver Aury Lopes Jr. e Gustavo Henrique Badaró, op. cit., p. 67.

${ }^{431}$ Alegando que a apuração de crimes cometidos por organizações criminosas denotam maior complexidade, necessitando de maior tempo para a conclusão do processo, ver: TRF $1^{\text {a }}$ Região, HC 2008.01.00.0123404/DF, Quarta Turma, Rel. Des. Fed. Mário César Sobrinho, j. 19/05/2008, DJ de 25/07/2008; TRF $1^{\text {a }}$ Região, HC 2007.01.00.029440-8/DF, Quarta Turma, Rel. Des. Fed. Mário César Ribeiro, j. 28/08/2007, DJ de 26/09/2007; TRF $1^{\text {a }}$ Região, HC 2001.01.00.016687-4/PI, Terceira Turma, Rel. Juiz Luciano Tolentino Amaral, j. 12/06/2001, DJ de 14/08/2001; TRF 4a Região, HC 2006.04.00.009070-2, Sétima Turma, Rel. Néfi Cordeiro, j. 25/04/2006, DJ de 10/05/2006; TRF 4 Região, HC 2008.04.00.022770-4, Oitava Turma, Rel. Élcio Pinheiro de Castro, j. 23/07/2008, DJ de 30/07/2008; TRF 3a Região, HC 2008.03.00.022626-6, Segunda Turma, Rel. Juiz Cotrim Guimarães, j. 30/09/2008, DJ de 16/10/2008; TRF $3^{\text {a }}$ Região, HC 2008.03.00.018553-7, Quinta Turma, Rel. Juíza Ramza Tartuce, j. 18/08/2008, DJ de 09/09/2008; TRF $3^{\text {a }}$ Região, HC 2008.03.00.006942-2, Primeira Turma, Rel. Juiz Johnsom Di Salvo, j. 12/08/2008, DJ de 08/09/2008; TRF 3 $3^{\text {a }}$ Região, HC 2008.03.00.013847-0, Segunda Turma, Rel. Juíza Cecília Mello, j. 01/07/2008, DJ de 17/07/2008.
}

\footnotetext{
432 "Não apresentando o processo qualquer complexidade, o excesso de prazo para a conclusão da instrução é injustificável, constituindo constrangimento ilegal a manutenção do acusado na prisão, por mais de sete meses" (TRF 1ª Região, HC 2008.01.00.000742-8/MA, Terceira Turma, Rel. Des. Fed. Tourinho Neto, j. 12/02/2008, DJ de 22/02/2008).

${ }^{433}$ Artigo Art. 77, $\S 2^{\circ}$ "Se a complexidade ou circunstâncias do caso não permitirem a formulação da denúncia, o Ministério Público poderá requerer ao Juiz o encaminhamento das peças existentes, na forma do parágrafo único do art. 66 desta Lei”.
} 
de duração do processo. "O grande problema está em que tais atos processuais constituem apenas um modelo de procedimento em ideal, orientando mais a ordem ou a lógica a era seguida para o desenvolvimento dos atos, do que propriamente a realidade de cada procedimento tal como se dá em concreto. Em muitas ocasiões devem ser realizados atos adicionais aos previstos, imprescindíveis no caso concreto, mas que demandam tempo adicional para a sua efetivação, tais como a necessidade de realização de perícias, de diligências para a localização de testemunhas, acareações, reprodução simuladas dos fatos, degravação de escutas telefônicas, etc., que não têm individualmente prazos legais para a sua realização". 434

Assim, cada caso deve ser analisado em concreto, verificando-se quais foram as dificuldades enfrentadas no desenvolver procedimental, e se estas justificam, ou não, uma dilação no procedimento, prolongando a duração total do processo.

Algumas situações freqüentes na prática forense são apontadas pela jurisprudência como fatores indicativos da complexidade objetiva da causa, justificando relativa dilação processual, desde que dentro dos limites da razoabilidade. É o caso, por exemplo, da necessidade de expedição de cartas precatórias ${ }^{435}$, julgamento de incidentes processuais $^{436}$, realização de exames e perícias ${ }^{437}$, degravação de conversas telefônicas

${ }^{434}$ Maria Thereza Rocha de Assis Moura e Thaís Aroca Datcho Lacava, op. cit., pp. 410-411.

${ }^{435}$ STF, HC 87550/BA, Primeira Turma, Rel. Min. Marco Aurérlio, Rel. p/ acórdão Min. Menezes Direito, j. 04/03/2008, DJ de 09/05/2008; STF, HC 91430/PA, Segunda Turma, Rel. Min. Eros Grau, j. 04/09/2007, DJ de 22/02/2008; STJ, RHC 16975, Sexta Turma, Rel. Min. Hélio Quaglia Barbosa, j. 19/04/2005, DJ de 09/05/2005; STJ, HC 38251, Quinta Turma, Rel. Min. Arnaldo Esteves Lima, j. 18/11/2004, DJ de 09/02/2005; STJ, RHC 16819, Quinta Turma, Rel. Min. Laurita Vaz, j. 07/12/2004, DJ de 01/12/2004; TRF $1^{\text {a }}$ Região, HC 2008.01.00.020511-0/BA, Quarta Turma, Rel. Des. Fed. Ítalo Fioravanti Sabo Mendes, j. 24/06/2008, DJ de 25/07/2008; TRF $1^{\text {a }}$ Região, HC 2008.01.00.024317-2/MA, Terceira Turma, Rel. Des. Fed. Assusete Magalhães, j. 18/06/2008, DJ de 27/06/2008; TRF 1ª Região, HC 2008.01.00.024140-1/RO, Terceira Turma, Rel. Des. Fed. Assusete Magalhães, j. 18/06/2008, DJ de 27/06/2008; TRF $1^{\text {a }}$ Região, HC 2008.01.00.004394-5/MG, Quarta Turma, Rel. Des. Fed. Mário César Ribeiro, j. 10/03/2008, DJ de 10/07/2008; TRF 4 $4^{\mathrm{a}}$ Região, HC 1999.04.01.063642-7, Primeira Turma, Rel. José Luiz Borges Germano da Silva, j. 13/10/1999, DJ de 27/10/1999; TRF 4 Região, HC 1998.04.01.009061-1, Primeira Turma, Rel. Antônio Balbino Ramos de Oliveira, j. 12/05/1998, DJ de 03/06/1998; TJSP, HC 990081239760, Quinta Câmara, Rel. Tristão Ribeiro, j. 11/12/2008, DJ de 09/01/2009; TRF 3 ${ }^{\text {a }}$ Região, HC 2008.03.00.035127-9, Segunda Turma, Rel. Juiz Enrique Herkenhoff, j. 09/12/2008, DJ de 18/12/2008; TRF 3 ${ }^{\text {a }}$ Região, ACR. 2007.61.19.008540-6, Segunda Turma, Rel. Juiz Enrique Herkenhoff, j. 28/10/2008, DJ de 06/11/2008. Em sentido contrário, afirmando que "o fato de a inquirição de testemunhas ter que ser feito por precatória não justifica o excesso de prazo na instrução, nem mesmo a complexidade ou gravidade dos fatos a apurar ou o número de acusados", ver TRF $1^{\mathrm{a}}$ Região, HC 2001.01.00.031164-2/TO, Turma Especial de Férias, Rel. Juiz Eustáquio Silveira, j. 26/07/2001, DJ de 15/01/2002.

${ }^{436}$ Nesse sentido: STJ, HC 87656, Quinta Turma, Rel. Min. Laurita Vaz, j. 27/03/2008, DJ de 22/04/2008; STJ, HC 32299, Quinta Turma, Rel. Min. Jorge Scartezzini, j. 01/04/2004, DJ de 24/05/2004; TRF da $1^{\text {a }}$ Região, 2008.01.00.013914-2/MG, Quarta Turma, Rel. Des. Fed. Ítalo Fioravanti, j. 24/06/2008, DJ de 25/07/2008; TRF 1 a Região, HC 2007.01.00.057799-5/MA, Quarta Turma, Rel. Des. Fed. Mário César Ribeiro, j. 01/04/2008, DJ de 22/04/2008. 
interceptadas $^{438}$, expedição de ofícios $^{439}$, necessidade de tradução de peças e documentos $^{440}$, assim como a grande quantidade de prova produzida, demandando a análise de muitos documentos e volumes de autos ${ }^{441}$.

Outro fator de ordem objetiva que não pode ser desprezado é a acusação da prática de diversos crimes numa mesma denúncia, o que, sem dúvida, acaba atrapalhando o trâmite processual ${ }^{442}$.

É de se ressaltar, ainda, que a gravidade do crime apurado não tem qualquer relação com a complexidade para a colheita da prova na instrução, não justificando, portanto, a sua invocação, assim como de outros fatores de ordem externa ao procedimento

${ }^{437}$ STJ, HC 83475, Sexta Turma, Rel. Min. Maria Thereza de Assis Moura, j. 25/02/2008, DJ de 17/03/2008;
STJ, HC 73905, Sexta Turma, Rel. Min. Paulo Galotti, j. 02/10/2007, DJ de 29/10/2007; STJ, HC 85684,
Quinta Turma, Rel. Min. Jane Silva (Desembargadora Convocada do TJ/MG), j. 04/10/2007, DJ de
22/10/2007; STJ, HC 40019, Quinta Turma, Rel. Min. Laurita Vaz, j. 01/03/2005, DJ de 28.03/2005; STJ,
HC 35462, Quinta Turma, Rel. Min. Gilson Dipp, j. 05/08/2004, DJ de 20/09/2004; TJRJ, HC
2008.059.07871, Sétima Câmara, Rel. Des. Alexandre H. Varella, j. 25/11/2008; TJRJ, HC 2008.059.07171,
Sétima Câmara, Rel. Des. Elizabeth Gregory, j. 18/11/2008; TJRJ, HC 2008.059.07362, Quarta Câmara, Rel.
Des. Fátima Clemente, j. 18/11/2008; TJRS, HC 70027268481, Primeira Câmara, Rel. Marco Antônio
Ribeiro de Oliveira, j. 19/11/2008, DJ de 19/12/2008.

${ }^{438}$ STJ, HC 83475, Sexta Turma, Rel. Min. Maria Thereza de Assis Moura, j. 25/02/2008, DJ de 17/03/2008; STJ, HC 40416, Quinta Turma, Rel. Min. Arnaldo Esteves Lima, j. 28/06/2005, DJ de 22/08/2005; TJRJ, HC 2008.059.07693, Primeira Câmara, Rel. Des. Marcus Basílio, j. 13/11/2008.TJRJ, HC 2008.059.07701, Primeira Câmara, Rel. Des. Marcus Basílio, j. 13/11/2008.

${ }^{439}$ STJ, HC 88676, Quinta Turma, Rel. Min. Arnaldo Esteves Lima, j. 08/11/2007, DJ de 07/02/2008; TRF $4^{\text {a }}$ Região, HC 2006.04.00.017168-4, Sétima Turma, Rel. Marcelo de Nardi, j. 27/06/2006, DJ de 12/07/2006.

${ }^{440}$ TRF $3^{a}$ Região, HC 2008.03.00.030598-1, Segunda Turma, Rel. Juiz Cotrim Guimarães, j. 30/09/2008, DJ de 16/10/2008; TRF 3 $3^{a}$ Região, HC 2008.03.00.021151-2, Segunda Turma, Rel. Juíza Cecília Mello, j. 09/09/2008, DJ de 25/09/2008; TRF 3 ${ }^{a}$ Região, HC 2008.03.00.008647-0, Primeira Turma, Rel. Juíza Vesna Kolmar, j. 06/05/2008, DJ de 23/06/2008; TRF $3^{\text {a }}$ Região, HC 2008.03.00.000437-3, Primeira Turma, Rel. Juiz Johonsom Di Salvo, j. 25/03/2008, DJ de 05/05/2008.

${ }^{441}$ Nesse sentido: STJ, HC 84956/SP, Quinta Turma, Rel. Min. Felix Fischer, j. 04/09/2007, DJ de 08/10/2007; TJRJ, HC 2008.059.07136, Terceira Câmara, Rel. Des. Valmir de Oliveira Silva, j. 04/11/2008; TJRJ, HC 2008.059.05129, Primeira Câmara, Rel. Des. Marcus Basilio, j. 25/11/2008; TRF $3^{\mathrm{a}}$ Região, HC 2007.03.00.081813-0, Segunda Turma, Rel. Juiz Cotrim Guimarães, j. 05/08/2008, DJ de 14/08/2008; TRF $3^{\mathrm{a}}$ Região, HC 2006.03.00.024514-8, Primeira Turma, Rel. Juiz Johonsom Di Salvo, j. 22/08/2006, DJ de $12 / 09 / 2006$.

${ }^{442}$ STF, HC 89090/GO, Segunda Turma, Rel. Min. Gilmar Mendes, j. 21/11/2006, DJ de 05/10/2007; TJMG, HC 1.0000.07.462920-5, Rel. Fernando Starling, j. 20/11/2007, DJ de 29/11/2007; TJRJ, HC 2008.059.05129, Primeira Câmara, Rel. Des. Marcus Basilio, j. 25/11/2008; TJRS, HC 70027100668, Primeira Câmara, Rel. Ivan Leomar Bruxel, j. 12/11/2008, DJ de 17/12/2008; TRF $3^{\text {a }}$ Região, HC 2007.03.00.081813-0, Segunda Turma, Rel. Juiz Cotrim Guimarães, j. 05/08/2008, DJ de 14/08/2008. 
em si, tais como periculosidade do agente, como razões justificadoras de eventual demora na conclusão do processo $^{443}$.

Por fim, no que se refere à complexidade subjetiva, é de se destacar a pluralidade de acusados ${ }^{444}$, especialmente se defendidos por advogados distintos ${ }^{445}$. O

${ }^{443}$ Conferir, nesse sentido, os seguintes julgados do Supremo Tribunal Federal: HC 89622/BA, Primeira Turma, Rel. Min. Carlos Britto, j. 03/06/2008, DJ de 18/09/2008; HC 93786/ES, Primeira Turma, Rel. Min. Carlos Britto, j. 17/06/2008, DJ de 30/10/2008; HC 93523/SP, Primeira Turma, Rel. Min. Carlos Britto, j. 29/04/2008, DJ de 16/10/2008. No mesmo sentido: TJRJ, HC 2008.059.06632, Segunda Câmara, Rel. Des. Kátia Jangutta, j. 28/10/2008; TJSP, HC 990080776711, Décima Segunda Câmara, Rel. Celso Limongi, j. 05/11/2008, DJ de 29/12/2008; TJSP, HC 990080587307, Sexta Câmara, Rel. Marco Antônio, j. 27/11/2008, DJ de 22/12/2008; TJSP, HC 990081157063, Segunda Câmara, Rel. Francisco Orlando, j. 10/11/2008, DJ de 10/12/2008; TJSP, HC 993080378134, Quinta Câmara, Rel. Carlos Biasotti, j. 03/07/2008, DJ de 28/07/2008; TJSP, HC 10598213600, Quinta Turma, Rel. Carlos Biasotti, j. 26/04/2007, DJ de 26/04/2007. Há julgados em sentido inverso, todavía, afirmando que "o prazo estabelecido na lei para a prisão processual não tem caráter absoluto, podendo ser prorrogado se o recomendarem a periculosidade do réu, a gravidade do delito" (TJSP, HC 990081620987, Sexta Câmara, Rel. José Raul Gavião de Almeida, j. 27/11/2008, DJ de 18/12/2008). Em sentido semelhante: TJSP, HC 99080378827, Quarta Câmara, Rel. Luis Soares de Mello; TJSP, HC 990080017098, Sexta Câmara, Rel. José Raul Gavião de Almeida, j. 29/05/2008, DJ de 19/06/2008; TJRJ, HC 2008.059.07695, Primeira Câmara, Rel. Des. Marcus Basilio, j. 27/11/2008; TJRJ, HC 2008.059.06423, Quarta Câmara, Rel. Des. Gizelda Leitão Teixeira, j. 23/09/2008; TRF 3 $3^{\mathrm{a}}$ Região, HC 2007.03.00.101650-0, Segunda Turma, Rel. Juiz Cotrim Guimarães, j. 16/09/2008, DJ de 03/10/2008; TRF 3 ${ }^{\text {a }}$ Região, HC 2007.03.00.089754-5, Segunda Turma, Rel. Juiz Cotrim Guimarães, j. 22/07/2008, DJ de $31 / 07 / 2008$

${ }^{444}$ Ver por exemplo, STF, Edcl no HC 87724/PI, Segunda Turma, Rel. Min. Ellen Gracie, j. 30/09/2008, DJ de 24/10/2008; STF, HC 95045/RJ, Segunda Turma, Rel. Min. Ellen Gracie, j. 09/09/2008, DJ de 20/09/2008; HC 92848/PR, Segunda Turma, Rel. Min. Ellen Gracie, j. 10/06/2008, DJ de 22/08/2008; STF, HC 94509/RJ, Primeira Turma, Rel. Min, Ricardo Lewandowski, j. 06/05/2008, DJ de 13/06/2008; STF, HC 93293/MS, Primeira Turma, Rel. Min. Menezes Direito, j. 18/03/2008, DJ de 25/04/2008. Ver, ainda, dentre muitos, os seguintes julgados: STJ, RHC 22468, Quinta Turma, Rel. Min. Laurita Vaz, j. 08/05/2008, DJ de 02/06/2008; STJ, RHC 22419, Quinta Turma, Rel. Min. Arnaldo Esteves Lima, j. 27/03/2008, DJ de 02/06/2008; STJ, HC 87319, Sexta Turma, Rel. Min. Maria Thereza de Assis Moura, j. 22/04/2008, DJ de 19/05/2008; STJ, HC 95618, Quinta Turma, Rel. Min. Napoleão Nunes Maia Filho, j. 22/04/2008, DJ de 19/05/2008; STJ, HC 83537, Sexta Turma, Rel. Min. Maria Thereza de Assis Moura, j. 17/12/2007, DJ de 18/02/2008; STJ, HC 91982, Quinta Turma, Rel. Min. Jane Silva (Desembargadora Convocada do TJ/MG), j. 27/11/2007, DJ de 17/12/2007; TRF $1^{\text {a }}$ Região, HC 2008.01.00.022856-7/GO, Terceira Turma, Rel. Des. Fed. Tourinho Neto, j. 03/06/2008, DJ de 1306/2008; TRF $1^{\text {a }}$ Região, HC 2008.01.00.004394-5/MG, Quarta Turma, Rel. Des. Fed. Mário César Ribeiro, j. 10/03/2008, DJ de 10/07/2008; TRF $1^{\text {a }}$ Região, HC 2007.01.00.056930-9/PA, Quarta Turma, Rel. Des. Fed. Ítalo Fioravanti Sabo Mendes, j. 12/02/2008, DJ de 12/03/2008; TJMG, HC 1.0000.08.480341-0, Rel. Pedro Vergara, j. 23/09/2008, DJ de 27/10/2008; TJMG, HC 1.0000.07.462920-5, Rel. Fernando Starling, j. 20/11/2007, DJ de 29/11/2007; TJMG, HC 1.0000.08.473167-8, Rel. Walter Pinto da Rocha, j. 14/05/2008, DJ de 31/05/2008; TJRJ, HC 2008.059.07692, Primeira Câmara, Rel. Des. Marcos Basilio, j. 27/11/2008; TJRJ, HC 2008.059.06388, Quarta Câmara, Rel. Des. Nilza Bitar, j. 14/10/2008; TJRJ, HC 2008.059.05129, Primeira Câmara, Rel. Des. Marcus Basilio, j. 25/11/2008; TJRS, HC 70027100668, Primeira Câmara, Rel. Ivan Leomar Bruxel, j. 12/11/2008, DJ de 17/12/2008. Em sentido contrário, afirmando que "o fato de a inquirição de testemunhas ter que ser feito por precatória não justifica o excesso de prazo na instrução, nem mesmo a complexidade ou gravidade dos fatos a apurar ou o número de acusados", ver TRF 1 ${ }^{\mathrm{a}}$ Região, HC 2001.01.00.031164-2/TO, Turma Especial de Férias, Rel. Juiz Eustáquio Silveira, j. 26/07/2001, DJ de 15/01/2002.

${ }^{445}$ Nesse sentido: STF, Edcl no HC 87724/PI, Segunda Turma, Rel. Min. Ellen Gracie, j. 30/09/2008, DJ de 24/10/2008; STF, HC 95045/RJ, Segunda Turma, Rel. Min. Ellen Gracie, j. 09/09/2008, DJ de 20/09/2008; TRF $4^{a}$ Região, HC 2006.04.00.024052-9, Sétima Turma, Rel. Tadaaqui Hirose, j. 29/08/2006, DJ de $13 / 09 / 2006$ 
número de vítimas ${ }^{446}$ e testemunhas ${ }^{447}$ envolvidas no processo, igualmente, pode ser citado como fator que contribui de forma relevante para a sua demora, pois pressupõe um maior número de diligências para citação ou intimação, localização, precatórias, assim como maior número para apreciação de petições e julgamento de incidentes e recursos.

No que se refere ao número de testemunhas, seu número máximo já vem estabelecido em lei ${ }^{448}$, e a sua livre nomeação pelas partes não pode ser tolhida ${ }^{449}$. Além

\footnotetext{
${ }^{446}$ STF, HC 88435/GO, Primeira Turma, Rel. Min. Marco Aurélio, Rel. p/ acórdão Min. Cármen Lúcia, j. 13/02/2007, DJ de 05/10/2007; TJRJ, HC 2008.059.088083, Quarta Câmara, Rel. Des. Eunice Ferreira Caldas, j. 09/12/2008.
}

${ }^{447}$ STF, Edcl no HC 87724/PI, Segunda Turma, Rel. Min. Ellen Gracie, j. 30/09/2008, DJ de 24/10/2008; STF, HC 95045/RJ, Segunda Turma, Rel. Min. Ellen Gracie, j. 09/09/2008, DJ de 20/09/2008; STF, HC 89168/RO, Primeira Turma, Rel. Min. Cármen Lúcia, j. 26/09/2006, DJ de 20/10/2006; STJ, HC 63606, Quinta Turma, Rel. Min. Gilson Dipp, j. 07/11/2006, DJ de 18/12/2006; TRF $1^{\text {a }}$ Região, HC 2008.01.00.017782-4/MT, Quarta Turma, Rel. Des. Fed. Mário César Ribeiro, j. 10/06/2008, DJ de 27/06/2008; TRF 4a Região, HC 2005.04.01.057740-1, Sétima Turma, Rel. Artur César de Souza, j. 07/02/2006, DJ de 22/02/2006; TJRS, HC 70027100668, Primeira Câmara, Rel. Ivan Leomar Bruxel, j. 12/11/2008, DJ de 17/12/2008; TRF $3^{\text {a }}$ Região, HC 2008.03.00.003431-6, Primeira Turma, Rel. Juiz Johonsom Di Salvo, j. 01/04/2008, DJ de 18/04/2008.

${ }^{448}$ O número máximo de testemunhas é de 8 para cada uma das partes no procedimento ordinário (artigo 401 do Código de Processo Penal) e de 5 no procedimento sumário (artigo 531 do Código de Processo Penal). A doutrina sempre viu espaço para o acréscimo destes números se o juiz entender por bem ouvir ainda outras testemunhas que se mostrarem necessárias para a busca da verdade, em homenagem ao princípio da ampla defesa. Nesse sentido, Fernando da Costa Tourinho Filho, Processo Penal, $3^{\circ}$ volume, $22^{\mathrm{a}}$ ed., São Paulo, Saraiva, 2000, p. 328.

${ }^{449}$ Discute-se se este número de testemunhas pode ser arrolado para cada acusado ou para cada fato criminoso narrado na denúncia. Há quem defenda, como Leandro Galuzzi dos Santos, que "o número máximo de testemunhas de acusação se dá em função da quantidade de fatos imputados ao acusado, de forma que para cada crime podem ser indicadas até 8 testemunhas. A regra vale, por óbvio, para a defesa, que também pode arrolar até 8 testemunhas para cada fato criminoso imputado ao agente" ("Procedimentos - Lei 11.719, de 20.06.2008". In: Maria Thereza Rocha de Assis Moura (coord.), As reformas no processo penal: as novas Leis de 2008 e os projetos de reforma, São Paulo, Revista dos Tribunais, 2008, p. 332). Tal entendimento, todavia, não resolve os seguintes questionamentos de ordem prática: se o número de 8 testemunhas vale para cada fato criminoso e não para cada acusado, como resolver o problema de colidência entre as defesas, em que cada acusado possui um defensor distinto e possui o interesse em desenvolver tese defensiva diferente das demais? A quem caberá decidir o nome das 8 testemunhas a serem ouvidas? Se forem 20 os acusados, por exemplo, quem determinará quais deles ficarão sem a possibilidade de indicar o nome de uma testemunha para falar em sua defesa? O que justifica que um mesmo acusado tenha o direito de arrolar 8 testemunhas para cada fato se responder ao processo sozinho (ou se tiver o seu processo desmembrado) e não tenha o mesmo direito se responder ao processo em conjunto com outros co-réus? Como bem ressaltado por Guilherme de Souza Nucci, "lembremos que o Ministério Público é uma das partes e cada réu, havendo mais de um, ainda que com o mesmo defensor, é individualmente parte, razão pela qual pode ser arrolado o número máximo mencionado para cada uma." (Código de Processo Penal Comentado, São Paulo, Revista dos Tribunais, 2002, p. 624). Por estas razões, o entendimento que melhor se adapta às exigências da prática forense e que melhor privilegia o exercício da ampla defesa é aquele que considera que o número de testemunhas deverá ser de 8 para cada fato criminoso e 8 para cada acusado, cumulativamente. Isto quer dizer que se forem imputados 3 crimes a 5 acusados, cada acusado terá o direito de arrolar 24 testemunhas individualmente, ainda que contem com defensor comum. Este é o entendimento de Vicente Greco Filho, Manual de Processo Penal, $6^{a}$ ed., São Paulo, Saraiva, 1999, p. 232, e, ainda, Julio Fabbrini Mirabete, Processo Penal, $18^{\mathrm{a}}$ ed., revista e atualizada por Renato N. Fabbrini, São Paulo, Atlas, 2006, p. 298. 
disso, nesse número não estão incluídas as testemunhas que não prestam compromisso e as testemunhas referidas ${ }^{450}$.

A pluralidade de acusados, todavia, é um fator que pode ser controlado. Há disposição expressa no Código de Processo Penal autorizando o desmembramento do processo quando o número de acusados puder prejudicar o andamento do processo. De acordo com o artigo 80, "será facultativa a separação dos processos quando as infrações tiverem sido praticadas em circunstâncias de tempo ou de lugar diferentes, ou, quando pelo excessivo número de acusados e para não lhes prolongar a prisão provisória, ou por outro motivo relevante, o juiz reputar conveniente a separação".

Assim, considerando que o juiz tem a faculdade de desmembrar o processo, não se pode admitir que a pluralidade de acusados possa isoladamente justificar a delonga do procedimento ${ }^{451}$. A manutenção da reunião dos processos em casos em que diversos são os acusados deve ser determinada em decisão motivada pelo magistrado, para que o acusado que se sinta prejudicado possa impugnar os fundamentos utilizados para tanto, assim como pleitear o relaxamento de eventual prisão cautelar contra si decretada.

Como bem observado pela doutrina, "a pluralidade de acusados serve como justificativa a uma relativa extensão do procedimento, sempre que conjugado a outros fatores indicadores de complexidade, e desde que não seja possível ou recomendável na hipótese o desmembramento dos autos. Havendo a possibilidade de desmembramento, não há justificativa para o excesso de prazo em razão da pluralidade de réus no processo" ${ }^{\$ 2}$.

\subsubsection{Conduta das autoridades na condução do processo}

\footnotetext{
450 “Art. 401. Na instrução poderão ser inquiridas até 8 (oito) testemunhas arroladas pela acusação e 8 (oito) pela defesa. $\S 1^{\circ}$ Nesse número não se compreendem as que não prestem compromisso e as referidas.'

${ }^{451}$ Nesse sentido, os seguintes julgados: STF, HC 89479/PR, Primeira Turma, Rel. Min. Marco Aurélio, j. 21/11/2006, DJ de 05/10/2007 ("A apreciação do excesso de prazo considerada a prisão preventiva faz-se no campo objetivo, sendo desinfluente o número de envolvidos na ação, haja vista a possibilidade de desmembramento"); STJ, HC 59406, Sexta Turma, Rel. Min. Maria Thereza de Assis Moura, j. 25/03/2008, DJ de 22/04/2008; STJ, HC 89109, Sexta Turma, Rel. Min. Maria Thereza de Assis Moura, j. 18/12/2007, DJ de 17/03/2008; HC 50792, Quinta Turma, Rel. Min. Laurita Vaz, j. 05/12/2006, DJ de 05/02/2007; STJ, HC 42039, Sexta Turma, Rel. Min. Hamilton Carvalhido, j. 31/05/2005, DJ de 14/11/2005.

${ }^{452}$ Cf. Maria Thereza Rocha de Assis Moura e Thaís Aroca Datcho Lacava, op. cit., p. 413.
} 
No que se refere à conduta das autoridades responsáveis pela condução do processo, verifica-se uma tendência em se presumir a boa atuação das autoridades judiciais na condução do processo ${ }^{453}$, se não houver qualquer indicativo de negligência, desleixo ou desídia $^{454}$, mesmo nos casos em que o processo se delonga além do previsto para aquele tipo de caso $^{455}$.

Sob esta perspectiva, é possível encontrar na jurisprudência brasileira os seguintes indicativos de que as autoridades responsáveis pela condução do processo não procederam com a esperada diligência: a existência de longos hiatos entre os atos processuais $^{456}$ e a incapacidade da autoridade judicial apresentar causas justificadoras da demora $^{457}$.

${ }^{453}$ Podem ser apontados como indicativos desta tendência, dentre outros, $s$ seguintes julgados: TRF $1^{\text {a }}$ Região, HC 2008.01.00.028192-6/PI, Quarta Turma, Rel. Des. Fed. Mário César Ribeiro, j. 02/09/2008, DJ de 01/01/2008 ("Inexistindo elementos comprobatórios que permitam identificar a ocorrência do alegado excesso de prazo para a conclusão do inquérito policial e, se porventura existente, que a morosidade possa ser atribuída aos órgãos de persecução criminal, não é possível conhecer do pedido de liberdade provisória do investigado sob esse fundamento").

454 Estas são as expressões empregadas na maioria dos seguintes julgados: TRF $1^{\text {a }}$ Região, HC 2007.01.00.005836-2/AM, Terceira Turma, Rel. Des. Fed. Tourinho Neto, j. 13/03/2007, DJ de 23/03/2007 ("O importante é que não haja desleixo do juiz na condução do processo, na observância do prazo de 81 dias para a conclusão da instrução"); TRF $1^{a}$ Região, HC 2006.01.00.031056-3/GO, Terceira Turma, Rel. Des. Fed. Olindo Menezes, j. 05/09/2006, DJ de 22/09/2006; TJSP, HC 990081429497, Quinta Câmara, Rel. Pinheiro Franco, j. 11/12/2008, DJ de 09/01/2009; TJSP, HC 990081143585, Quinta Câmara, Rel. Pinheiro Franco, j. 27/11/2008, DJ de 12/12/2008; TJSP, HC 990080522540, Quinta Câmara, Rel. Pinheiro Franco, j. 11/09/2008, DJ de 24/09/2008; TRF 3 $3^{\text {a }}$ Região, HC 2008.03.00.027935-0, Primeira Turma, Rel. Juiz Johonsom, j. 04/11/2008, DJ de 17/11/2008.

${ }^{455}$ TJRS, HC 70027713544, Terceira Câmara, Rel. José Antônio Hirt Preiss, j. 18/12/2008, DJ de 30/12/2008 ("Embora tenha havido alargamento dos prazos, em nenhum momento deixou de haver solução de continuidade, inércia ou descaso do julgador”).

${ }^{456}$ A demora para se proceder ao interrogatório do acusado, por exemplo, é uma hipótese que tem causa na inércia do aparato judicial e que, portanto, não serve como justificativa para o excesso de prazo. Nesse sentido: TRF $1^{\text {a }}$ Região, HC 2007.01.00.053089-6/GO, Terceira Turma, Rel. Des. Fed. Olindo Menezes, j. 11/12/2007, DJ de 25/01/2008. Reconhecendo a existência de "hiatos" entre os atos processuais ou de paralisações injustificadas como indicativo da inércia do Estado, conferir os seguintes julgados: TJRJ, HC 2008.059.07754, Oitava Câmara, Rel. Des. Gilmar Augusto Teixeira, j. 10/12/2008; TJRJ, HC 2008.059.08061, Quarta Câmara, Rel. Des. Gilza Leitão Teixeira, j. 02/12/2008; TJRJ, HC 2008.059.05291, Quinta Câmara, Rel. Des. Geraldo Prado, j. 18/09/2008 ("Existência de períodos característicos de "tempo morto' no processo e a demora injustificada no cumprimento de diligências simples, fatos inaceitáveis, especialmente à luz do artigo $5^{\circ}$, LXXVIII da Constituição da República"); TJRJ, HC 2008.059.07092, Quinta Câmara, Rel. Des. Geraldo Prado, j. 19/11/2008; TJRJ, HC 2007.059.02555, Sétima Câmara, Rel. Des. Geraldo Prado, j. 29/05/2007; TJRJ, HC 2007.059.02469, Sétima Câmara, Rel. Des. Geraldo Prado, j. 22/05/2007; TRF $3^{\mathrm{a}}$ Região, HC 2008.03.00.022604-7, Quinta Turma, Rel. Juíza Eliana Marcelo, j. 01/09/2008, DJ de 16/09/2008; TRF $3^{\text {a }}$ Região, HC 2008.03.00.0121190-0, Primeira Turma, Rel. Juiz Johonsom Di Salvo, j. 10/06/2008, DJ de 18/08/2008; TRF 3 ${ }^{\text {a }}$ Região, HC 2007.03.00.105206-1, Primeira Turma, Rel. Juiz Johonsom Di Salvo, j. 25/03/2008, DJ de 05/05/2008.

${ }^{457}$ Nesse sentido: TJRJ, HC 2008.059.01289, Quinta Câmara, Rel. Des. Geraldo Prado, j. 13/03/2008 (“Não há como se considerar justificado o tempo decorrido desde a prisão em flagrante do paciente, em setembro do 
O tempo morto, ou seja, aquele período de tempo em que o processo fica parado, sem a realização de qualquer ato processual, ou à espera da realização de alguma providência, ou, ainda, na fila de espera para julgamento, é o principal problema apresentado na atualidade pelo Judiciário. Por mais que as partes sejam diligentes e cooperativas e, por mais que se trate de procedimento simples, o fato é que, muitas vezes, o processo demora por conta dessa ineficiência estatal.

Além disso, há fatores de ordem estrutural comumente invocados pelas autoridades judiciais na tentativa de justificação da demora processual que têm sido taxativamente afastados pelos tribunais brasileiros, tais como greves de serventuários ${ }^{458}$, excesso de trabalho ${ }^{459}$, dificuldade para a apresentação de réu preso a exames ou a audiência $^{460}$, inexistência de data disponível na pauta ${ }^{461}$, extravio e furto de autos ${ }^{462}$, falta de perito habilitado ${ }^{463}$, entre outras hipóteses ${ }^{464}$.

ano passado, até a presente data, ante a ausência do provimento jurisdicional, pois que a autoridade coatora não indicou motivo idôneo para a demora").

${ }^{458}$ STJ, HC 40355/SP, Quinta Turma, Rel. Min. Gilson Dipp, j. 21/06/2005, DJ de 01/07/2005, p. 578; STJ, RHC 16222/PA, Quinta Turma, Rel. Min. Gilson Dipp, j. 10/08/2004, DJ de 20/09/2004, p. 306.

${ }^{459}$ STF, HC 89479/PR, Primeira Turma, Rel. Min. Marco Aurélio, j. 21/11/2006, DJ de 05/10/2007 (“A apreciação do excesso de prazo considerada a prisão preventiva faz-se no campo objetivo, sendo desinfluente a circunstância de o juízo estar sobrecarregado, ante a avalanche de processos"); STJ, HC 85703/PI, Quinta Turma, Rel. Min. Napoleão Nunes Maia Filho, j. 18/08/2007, DJ de 16/08/2007, p. 339.

460 "O fato de o paciente não ter sido apresentado pelo estabelecimento prisional para a realização do exame não pode ser atribuído à defesa, porquanto uma vez encarcerado o paciente, tem-se que está à disposição da justiça. Assim, qualquer atraso na realização do aludido exame evidentemente deve ser imputado à própria Administração" (STJ, HC 38685/SP, Quinta Turma, Rel. Min. Laurita Vaz, j. 27/09/2005, DJ de 07/11/2005, p. 317). No mesmo sentido: TJRJ, HC 2007.059.03957, Sétima Câmara, Rel. Des. Geraldo Prado, j. 24/07/2007 ("Ao Estado incumbia o dever de encaminhar o paciente, preso cautelarmente, à presenta das autoridades competentes para a realização dos atos processuais designados"); TJRJ, HC 2007.059.03130, Sétima Câmara, Rel. Des. Geraldo Prado, j. 12/06/2007.

${ }^{461}$ STJ, HC 72103/MS, Quinta Turma, Rel. Min. Laurita Vaz, j. 15/02/2007, DJ de 12/03/2007, p. 307.

${ }^{462}$ No julgamento do HC 56697PI, Quinta Turma, Rel. Min. Felix Fischer, j. 28/11/2006, DJ de 26/02/2007, p. 618, por exemplo, considerou-se que "não se admite, por completa ausência de razoabilidade, a manutenção da prisão cautelar, a qual perdura quase 30 meses, em processo penal que se encontra parado em decorrência do extravio dos autos". Em hipótese semelhante: STJ, HC 55470/RJ, Quinta Turma, Rel. Min. Laurita Vaz, j. 28/11/2006, DJ de 18/12/2006, p. 420: "evidenciado que a demora no julgamento da apelação decorre da necessidade de restauração dos autos furtados, fato que não pode ser atribuído à defesa, é de se reconhecer o excesso de prazo na custódia cautelar do paciente (...)".

${ }^{463}$ A falta de perito habilitado para a realização de exame de insanidade mental na comarca, da mesma forma, não pode justificar o excesso de prazo (STJ, HC 60563/MS, Quinta Turma, Rel. Min. Gilson Dipp, j. 17/08/2006, DJ de 11/09/2006, p. 336).

${ }^{464}$ A ocorrência de problemas técnicos em órgãos da Polícia Judiciária, a impedir a realização de degravação de DVD's e outras diligências, por exemplo, não serve como justificativa para demora no procedimento, pois 
Fatores como a sucessão de leis no tempo e a necessidade de adaptação do procedimento à nova disciplina processual ${ }^{465}$ não são, igualmente, fatores suficientes para justificar o excesso de prazo, indicando, ao contrário, deficiência do órgão julgador na condução do processo.

Por fim, vale ressaltar que o critério da atuação das autoridades na condução do processo tem de ser analisado sob esta ótica de responsabilidade estatal e de proteção aos direitos individuais do acusado, já que é responsabilidade do Estado, inclusive perante organismos internacionais, o adequado aparelhamento do Poder Judiciário e a racionalização das leis processuais, com vistas à efetivação da garantia da razoável duração do processo.

\section{CRÍTICAS À DOUTRINA DO “NÃO-PRAZO”}

A existência de alguns critérios e parâmetros, já analisados neste trabalho, tanto no que se refere à noção de razoabilidade, quanto à idéia mesma de um prazo razoável de duração do processo, tem a vantagem de tornar mais delimitada e menos insegura a aplicação da garantia, na ausência de um prazo legal global para a duração tanto da persecução penal, quanto da própria prisão cautelar ${ }^{466}$. Todavia, estes parâmetros são insuficientes e não afastam a necessidade de uma iniciativa legislativa nesse sentido.

indica a ineficiência do aparelho estatal, que não pode prejudicar o acusado. Nesse sentido: TJRJ, HC 2007.059.02532, Sétima Câmara, Rel. Des. Geraldo Prado, j. 29/05/2007.

465 TRF $1^{\text {a }}$ Região, HC 2006.01.00.044829-2/AC, Terceira Turma, Rel. Des. Fed. Cândido Ribeiro, j. 30/01/2007, DJ de 16/02/2007; TJRJ, HC 2008.059.07411, Quinta Câmara, Rel. Des. Cairo Ítalo Franca David, j. 13/11/2008.

${ }^{466}$ Com exceção da prisão temporária, que tem seu prazo máximo de duração definido em lei (Lei 7.960/89), sendo de até 5 dias, prorrogáveis por igual período, e, em casos de crime considerado hediondo (Lei $8.072 / 90$ ), de 30 dias, prorrogáveis por mais 30 . 
A teoria conhecida como "doutrina do não-prazo" foi cunhada em uma decisão do Tribunal Europeu de Direitos Humanos, no caso Stögmüller, em que se afirmou "a impossibilidade de traduzir esse conceito em um número fixo de dias, de semanas, de meses ou de anos" ${ }^{\$ 47}$. O mesmo entendimento passou a ser reproduzido nos casos subseqüentes, tornando-se posição firme do Tribunal Europeu e da Corte Interamericana.

"De acordo com este entendimento, o prazo razoável não é um prazo (doutrina do não-prazo) no sentido processual penal, isto é, não considera referida expressão como condição de tempo, prevista em abstrato pela lei, dentro do qual - e somente dentro do qual - deve ser realizado um ato processual, ou um conjunto deles, mas uma indicação de que, uma vez concluído o processo, os juízes avaliem a duração que teve o caso para estimar, segundo uma série de critérios, se essa duração foi ou não razoável, e, caso não tenha sido, compensá-lo de alguma maneira"468.

$\mathrm{O}$ fato de terem as duas principais cortes internacionais de proteção aos direitos fundamentais afastado a idéia de um prazo determinado, fixado em dias, meses e anos, assim como estabelecido critérios para a análise da razoabilidade da duração do processo em cada caso concreto, poderia dar a entender que se estaria refutando a fixação de prazos globais pelo legislador de cada país, como defendido por parte da doutrina ${ }^{469}$, o que não é verdade.

Há recomendação, aliás, por parte destes dois tribunais, no sentido de que cada país providencie em sua legislação a previsão de um prazo máximo de duração do processo, mormente se de natureza criminal, fixando-se, ainda, critérios e parâmetros para a sua aferição.

Ocorre que os tribunais internacionais precisam analisar a razoabilidade da duração de processos de diferentes países, cada qual com sua realidade e cultura, mostrando-se-lhes impossível a fixação de um prazo único de duração para o processo que pudesse ser validamente imposto a todos. Ademais, a imposição de um prazo determinado, de forma tão limitativa, poderia ferir o princípio da soberania nacional, pois cabe a cada país, por meio de seu processo legislativo, criar as normas e os prazos de duração de seus processos, restando à Corte apenas verificar se, com a fixação de tais prazos, o Estado nega

\footnotetext{
${ }^{467}$ Daniel R. Pastor, El plazo razonable..., cit., p. 127.

${ }^{468}$ Daniel R. Pastor, “Acerca del derecho fundamental...”, cit., p. 216.

${ }^{469}$ Nesse sentido, José Rogério Cruz e Tucci, Tempo e processo, cit., pp. 67: "Todavia, torna-se impossível fixar a priori uma regra específica, determinante das violações ao direito à tutela jurisdicional dentro de um prazo razoável".
} 
ou não ao particular o direito a ser julgado num prazo razoável ${ }^{470}$. Daí porque, no âmbito internacional, justifica-se, até certo ponto, a análise da razoabilidade por meio de critérios mais ou menos fluidos. A perspectiva de tais organismos internacionais é, estando diante de uma alegação de violação já caracterizada, determinar eventual a compensação à vítima pelo Estado em razão da demora que se verificou no caso concreto. Trata-se, portanto, de uma análise ad posteriori.

Já no âmbito doméstico, isto não pode acontecer. Todas as atividades estatais que, de algum modo, interfiram na esfera de direitos e garantias individuais, devem ser previstas em lei ${ }^{471}$.

\subsection{Da obrigação do Estado em determinar legislativamente o prazo razoável de duração da persecução penal}

Especialmente as três principais atividades relacionadas ao Direito Penal, que pressupõem a aplicação de uma sanção, que são a de proibir, processar e julgar, devem se submeter ao princípio da reserva legal ${ }^{472}$, garantindo segurança jurídica não só ao acusado como a toda a sociedade, bem como reduzindo a possibilidade de eventual uso arbitrário do poder.

O tempo de duração do processo não escapa à mesma regra, já que se trata de um limite temporal ao próprio poder estatal, que não pode submeter um indivíduo a um processo ou procedimento penal eternamente. "Não há definição legal do que se deve entender por razoabilidade da duração do processo. Essa posição, conhecida como ‘doutrina do não-prazo', é extremamente criticável. Imprescindível, para eficácia do direito fundamental, que a lei preveja o máximo de duração da prisão e imponha como conseqüência automática do excesso, a soltura do réu. Por que todo indivíduo tem o direito

\footnotetext{
${ }^{470}$ Nesse sentido, Daniel R. Pastor, "Acerca del derecho fundamental...", cit., p. 223: "No plano internacional, a função dos órgãos de controle dos tratados será confrontar as regulações nacionais dos direitos convencionados para determinar se satisfazem as pretensões de um direito fundamental (controle de razoabilidade) ou se são suficientes para assegurar a sua plena vigência (função de garantia dos direitos fundamentais)".

471 "Por sua vez, o sistema político do Estado de Direito exige que as regras que restringem a atuação penal do Estado sejam estabelecidas pelo legislador de forma tal que os direitos fundamentais tenham uma vida prática e efetiva” (Daniel R. Pastor, “Acerca del derecho fundamental...”, cit., p. 227).

${ }^{472}$ Luigi Ferrajoli, op. cit., p. 233.
} 
de saber o prazo máximo de sua prisão, enquanto pena privativa de liberdade $\left(\mathrm{CR}\right.$, art. $5^{\circ}$, inciso XXXIX), que deve ser expressamente fixado em lei, mas não tem o direito de saber, de antemão e com precisão, qual é o tempo máximo que poderá durar um processo concreto, mormente estando preso?"473

Acerca da necessidade de disciplina infraconstitucional versando sobre a garantia da razoável duração do processo, pontua, ainda, SILVA FRANCO: "No direito processual brasileiro, não se formulou ainda uma adequada definição do conteúdo e do alcance do conceito de prazo razoável. E isso seria imprescindível, não apenas por causa do Pacto de São José da Costa Rica, mas, agora, principalmente, em razão do princípio estatuído no inc. LXXVIII do art. $5^{\circ}$ da Constituição Federal. Há, na realidade, exigência constitucional de que o prazo razoável de duração do processo tenha embasamento em lei infraconstitucional" ${ }^{\prime 474}$.

Ademais, a limitação temporal do poder judicial não pode ser fixada pela própria autoridade judicial, em decorrência da teoria da separação dos poderes ${ }^{475}$. No sistema de feios e contrapesos, deve haver uma limitação legal do poder do juiz, que, a despeito de trabalhar em um âmbito de discricionariedade, nunca poderá se apartar da legalidade.

Uma das principais críticas à adoção da doutrina do não-prazo, que foi tacitamente adotada pelo Brasil ${ }^{476}$, aliás, é justamente essa, de que a tarefa de estabelecer limites temporais à atuação jurisdicional é deixada a cargo do próprio Poder Judiciário ${ }^{477}$. Com a indefinição dos limites temporais do processo, coloca-se sob a responsabilidade do juiz o perigoso poder de definir por quanto tempo é razoável alongar-se o processo, mesmo que as causas da demora decorram da forma negligente como o conduziu.

Pertinente, nesse sentido, a crítica de SILVA FRANCO, que alerta: “Tratase [a garantia da razoável duração do processo] de princípio fundamental positivado em nível constitucional, e não de instrumento posto nas mãos do juiz para prorrogar

\footnotetext{
${ }^{473}$ Gustavo Henrique Righi Ivahi Badaró, op. cit., p. 30.

${ }^{474}$ Alberto Silva Franco, "Prazo razoável...”, cit., pp. 6 e 7.

${ }^{475}$ A respeito, conferir Daniel R. Pastor, “Acerca del derecho fundamental...”, cit., pp. 233-234.

${ }^{476}$ Nesse sentido, Aury Lopes Jr. e Gustavo Henrique Righi Ivahy Badaró, op. cit., p. 39.

${ }^{477}$ De acordo com Daniel R. Pastor, “Acerca del derecho fundamental...”, cit., p. 224, "permitir aos juízes, e não ao legislador, estabelecer os limites (inclusive temporais) de seus próprios poderes seria tão ingênuo como pedir ao lobo, e não ao pastor, que cuide das ovelhas".
} 
indefinidamente a duração do processo ou para exonerar-se da inércia ou do retardamento com que se houve na direção dele. Num Estado Democrático de Direito, a exigência de que o processo se finde em prazo razoável exclui qualquer concessão de espaço ao juiz para arbitrariamente determinar o ritmo do processo" ${ }^{478}$.

É claro que, diante de uma omissão legislativa, como ocorre no caso brasileiro, caberá ao Judiciário suprir momentaneamente esta lacuna, de molde a conferir eficácia imediata a um direito fundamental ${ }^{479}$. Para isso é que deverão ser utilizados os critérios até então analisados, que servirão de auxílio na tarefa interpretativa que envolve a aplicação da garantia da razoável de duração da persecução penal.

Tais critérios podem até auxiliar na aplicação judicial da garantia, mas não são suficientemente precisos para dar a legitimidade e a segurança jurídica necessárias, abrindo espaço à casuística. "Com efeito, se são analisados os padrões jurisprudenciais utilizados para a compreensão do significado de prazo razoável (natureza complexa do processo, pluralidade de réus, ocorrência de crime grave, o comportamento do acusado, e demora nos atos instrutórios, o retardamento da sentença o aguardo pelo julgamento do tribunal do júri, etc.), fácil será verificar que o princípio constitucional de que o desfecho deve ocorrer em um prazo razoável é puramente ilusório" ${ }^{480}$.

Cabe ao legislador, portanto, fixar determinado espaço de tempo que seja o menor possível para garantir, a um só tempo, o exercício da ampla defesa e a busca da verdade, que propicie o desenrolar de todas as fases procedimentais e incidentes inerentes ao devido processo legal. A favor da criação de prazo peremptórios de duração do processo, conferir TUCCI, para quem “o ideal seria a fixação de prazos peremptórios para a prática de atos processuais, como que delimitando, priori, o tempo de duração de determinado tipo de processo" ${ }^{\circ 81}$.

\footnotetext{
${ }^{478}$ Alberto Silva Franco, "Prazo razoável...", cit., pp. 6-7.

${ }^{479}$ Idem, ibidem. No mesmo sentido, Daniel R. Pastor, “Acerca del derecho fundamental...”, cit., p. 216: “Apenas em caso de ausência dessa regulamentação obrigatória é que os juízes terão que assumir um papel ativo, para impedir que a ausência de norma secundária impeça a efetividade do direito".

${ }^{480}$ Alberto Silva Franco, “Prazo razoável...”, cit., pp. 6-7.

${ }^{481}$ Direitos e garantias individuais..., cit., p. 256. No mesmo sentido, Aury Lopes Jr. e Gustavo Henrique Righi Ivahy Badaró, op. cit., p. 89.
} 
É de se ressaltar, todavia, que o simples fato de fixar um prazo legal de duração do processo em nada colaborará para a eficácia da garantia se, conjuntamente, não houver vontade política para aplicá-1o ${ }^{482}$.

É preciso, outrossim, que a lei preveja mecanismos e sanções para que o prazo legal seja de fato respeitado, uma vez que a solução meramente compensatória, consistente na responsabilização estatal pela demora do processo, não tem o condão de dar efetividade à garantia da razoável duração do processo, incidindo apenas quando já houve a violação e o direito fundamental do acusado já foi desrespeitado ${ }^{483}$.

A nulidade dos atos processuais realizados após o decurso do lapso legal, por outro lado, também não resolve suficientemente a questão, pois igualmente não barra a vulneração da garantia, incidindo apenas posteriormente, quando já realizados aqueles atos que levaram à demora da prestação jurisdicional e não levando necessariamente ao provimento absolutório ${ }^{484}$.

Do mesmo modo, soluções tais como indulto, inexecução da pena e atenuação da reprimenda, não se mostram adequadas, já que pressupõem a existência de condenação, desprezando-se, portanto, a possibilidade de absolvição, e tampouco resolvem a questão da continuidade do processo mesmo após o limite legal.

Defende PASTOR que a única solução que atende integralmente à necessidade de efetiva proteção da garantia é a solução processual de extinção ou arquivamento do feito, sem a possibilidade de nova acusação ${ }^{485}$. "Em resumo, os prazos de duração máxima do processo devem ser fixados legislativamente com caráter geral e com a conseqüência jurídica de que, ao cumprir-se esse limite, o processo deva cessar antecipada e definitivamente" ${ }^{486}$. Há, ainda, a possibilidade de aplicar-se na fase recursal, a exemplo

${ }^{482}$ Cf. Aury Lopes Jr., “Bom para quê(m)?”, Boletim IBCCrim no 16, ano 188, julho de 2008.

${ }^{483}$ E ressalte-e, ainda, que a solução de composição cível do dano pressupõe que a parte ingresse ainda pelas vias judiciárias e suporte a demora de outro processo, talvez até com nova violação da mesma garantia. Nesse sentido, conferir, a respeito, Aury Lopes Jr. e Gustavo Henrique Righi Ivahy Badaró, op. cit., pp. 122-123,

${ }^{484}$ Idem, p. 123.

${ }^{485}$ Daniel R. Pastor, “Acerca del derecho fundamental...”, cit., pp. 247-249.

${ }^{486}$ Idem, Daniel R. Pastor, “Acerca del derecho fundamental...”, cit., p. 248, traduzido livremente. No mesmo sentido, Jürgen Wolter e Georg Freund, El sistema integral del Derecho Penal: delito, determinación y proceso penal, Madrid, Marcel Pons, 2004, p. 40: "Nos casos de duração desproporcionalmente larga do processo penal (que praticamente alcança por completo a duração esperada da pena de prisão imponível) deveria utilizar-se a extinção do processo, em vez de uma causa de diminuição de pena ou a atenuação da pena ou à condenação com a renúncia da imposição da pena, no âmbito da individualização da mesma" (tradução livre). E, ainda: Aury Lopes Jr. e Gustavo Henrique Righi Ivahy Badaró, op. cit., pp. 122-123: "Como afirmado no início, a extinção do feito é a solução mais adequada, em termos processuais, na medida 
do que ocorre na legislação paraguaia, de resolução ficta, conforme melhor será abordado no item a seguir, em que o recurso que beneficia o acusado é automaticamente considerado provido após o decurso do prazo legal para o seu julgamento.

A previsão de soluções sancionatórias, embora não tenham o efeito de, isoladamente, assegurar a eficácia da garantia, pois também incidem posteriormente à violação, além de depender de comprovação da culpa do responsável pela demora, podem significar mais um reforço à solução extintiva já exposta, uma solução paliativa ${ }^{487}$. A Emenda Constitucional $\mathrm{n}^{\mathrm{o}} 45$ trouxe, aliás, uma solução do tipo compensatória, nos seguintes termos: "não será promovido o juiz que, injustificadamente, retiver autos em seu poder além do prazo legal, não podendo devolvê-los ao cartório sem o devido despacho ou decisão" ${ }^{488}$.

\subsection{Sugestão para a fixação dos prazos de duração no Brasil}

Para a realidade brasileira, aproveitando a forma como foi tecida a já referida "jurisprudência dos 81 dias", o ideal seria que a duração máxima de cada procedimento fosse determinada pela somatória dos atos processuais que se fizerem necessários em cada caso concreto. Para tanto, cada ato processual precisaria ter um prazo de realização legalmente estabelecido.

Do mesmo modo, deveria haver um prazo máximo de duração para cada tipo de procedimento, mais condizente com a realidade ${ }^{489}$, que não pudesse ser ultrapassado em nenhuma hipótese ou que pudesse ser prorrogado, de maneira justificada e motivada, por uma única vez, pelo juiz. Esse seria o prazo razoável de duração do processo no Brasil.

em que, reconhecida a ilegitimidade do poder punitivo pela própria desídia do Estado, o processo deve findar. Sua continuação, além do prazo razoável, não é mais legítima e vulnera o princípio da legalidade, fundante do Estado de Direito (...)".

\footnotetext{
${ }^{487}$ Nesse sentido, Aury Lopes Jr. e Gustavo Henrique Righi Ivahy Badaró, op. cit., pp. 122-123,

${ }^{488}$ Artigo 98, inciso II, alínea e.

${ }^{489}$ A crítica mais contundente à fixação jurisprudencial para a verificação do excesso de prazo com base na soma aritmética dos prazos processuais é que, em primeiro lugar, ela ignora a existência de "tempos mortos" dentro do procedimento, em que se deve aguardar a realização de uma determinada providência. Além disso, verifica-se que os prazos empregados neste quantum não englobam todos os atos do procedimento, mas apenas algumas fases mais relevantes.
} 
Outra necessidade a ser suprida legislativamente é a previsão das hipóteses em que seria aceitável essa prorrogação, por exemplo, nos casos em que o juiz verificar que as circunstâncias do caso concreto demandem, por sua complexidade, maior prazo para a conclusão do processo. Com tal mecanismo, evitar-se-ia, em grande medida, a utilização indiscriminada e atécnica do princípio da razoabilidade para a extensão dos prazos processuais, passando-se a trabalhar num quadro de maior segurança jurídica, ao mesmo tempo em que se possibilitaria certo grau de flexibilidade ao sistema, absolutamente necessário para não engessá-lo de tal modo a inviabilizar a atuação do Estado na persecução de crimes.

Essencial, ainda, a previsão de uma causa extintiva de punibilidade, de natureza processual, a ser decretada sempre que ultrapassado o prazo máximo de duração do processo.

O Paraguai foi um dos poucos países a entender a necessidade de contemplação legal de prazos para regular a duração do processo, de forma a viabilizar a eficácia da garantia da razoável duração do processo ${ }^{490}$, prevendo toda uma sistemática voltada a barrar o excesso de prazo. A iniciativa paraguaia é digna de elogios, já que, mesmo em se tratando de um país sul-americano, que enfrenta os mesmos tipos de deficiência que o Brasil, ousou fazer uma reforma processual aprofundada que, "além de corajosamente avançada, possui um princípio unificador" ${ }^{\text {"491 }}$.

Dentre os mecanismos trazidos pela legislação Paraguai, destacam-se os seguintes, de grande relevância para garantir a eficácia do direito a ser julgado num prazo razoável: (i) previsão de um prazo geral, a ser aplicado para a realização de atos não previstos em lei ou no procedimento padrão ${ }^{492}$; (ii) previsão de um prazo máximo de duração do processo $^{493}$; (iii) previsão de indenização à vítima de morosidade judicial,

\footnotetext{
490 Para os autores Aury Lopes Jr. e Gustavo Henrique Righi Ivahy Badaró, o Código de Processo Penal paraguaio é "um bom exemplo de limite normativo interno" (Op. cit., pp. 88).

${ }^{491}$ Idem, p. 89.

${ }^{492}$ Cf. artigo 133: “os incidentes serão resolvidos dentro de três dias, sempre que a lei não disponha de modo diverso".

493 Cf. artigo 136: “Toda pessoa terá direito a uma prestação jurisdicional definitiva em um prazo razoável. Para tanto, todo procedimento terá uma duração máxima de 3 anos, contados desde o primeiro ato do procedimento.

Este prazo somente poderá ser estendido por mais 6 meses, quando exista um sentença condenatória, a fim de permitir a tramitação dos recursos.

A fuga ou revelia do imputado interromperá o prazo de duração do procedimento.

Quando comparecer ou for recapturado, reiniciar-se-á o prazo".
} 
presumindo-se a negligência do Estado sempre que for extinto o processo por esse motivo $^{494}$; (iv) utilização do prazo prescricional como um prazo incidental de controle da duração do processo, sempre e apenas quando for inferior ao prazo máximo do processo estabelecido em $1 \mathrm{ei}^{495}$; (v) se o Ministério Público quedar inerte, não oferecendo a denúncia nem requerendo o arquivamento do feito, o juiz deverá declarar extinta a ação penal $^{496}$; (vi) previsão de um meio de impugnação específico à disposição da parte para reclamar sobre a demora no julgamento ${ }^{497}$; (vii) em caso de pedido de liberdade provisória ou de revogação de prisão preventiva, se não houver decisão no prazo de 24 horas, o acusado deverá ser posto imediatamente em liberdade ${ }^{498}$; (viii) a previsão de que o recurso que não for julgado no prazo legal deverá ser provido, salvo se desfavorável ao imputado $^{499}$.

${ }^{494}$ Cf. artigo 137: "Vencido o prazo previsto no artigo anterior o juiz ou tribunal, de ofício ou a petição da parte, declarará extinta a ação penal, conforme o previsto por este Código.

Quando se declarar a extinção do processo por morosidade judicial, a vítima deverá ser indenizada pelos funcionários responsáveis de pelo Estado. Presumir-se-á a negligência dos funcionários atuantes, salvo prova em contrário. Em caso de insolvência do funcionário, responderá diretamente o Estado, sem prejuízo do direito de regresso".

${ }^{495}$ Cf. artigo 138: “A duração do procedimento não poderá superar o prazo previsto para a prescrição da ação penal, quando esta for inferior ao máximo previsto neste capítulo".

${ }^{496}$ Cf. artigo 139: “Quando o Ministério não oferecer denúncia, nem apresentar outro requerimento no prazo fixado pelo juiz, nem tampouco pedir prorrogação do prazo, o juiz intimará o Procurador-Geral da República para requerer o que entender pertinente no prazo de 10 dias. Transcorrido esse prazo sem qualquer pedido do Ministério Público, o juiz declarará extinta a ação penal, sem prejuízo da responsabilidade pessoal do Procurador-Geral da República ou do promotor interveniente".

${ }^{497}$ Cf. artigo 140: "Se o juiz ou tribunal não resolve a questão correspondente nos prazos assinalados por este Código, o interessado poderá exigir pronto despacho, e se, dentro de 24 horas não o obtém, poderá interpor queixa por demora judicial. O juiz ou tribunal, com um breve informe sobre os motivos de sua demora, determinará a imediata realização das atividades correspondentes. O tribunal que conheça da queixa resolverá diretamente o solicitado, quando seja possível, ou determinará ao juiz para que o faça dentro das 24 horas contadas a partir da devolução dos autos. Se o juiz ou tribunal insistir em não decidir, será substituído imediatamente, sem prejuízo de sua responsabilidade pessoal".

${ }^{498}$ Cf. artigo 141: "Quanto se pleitear a revisão de uma medida cautelar privativa de liberdade ou se apelar de uma decisão denegatória da liberdade, e o juiz não resolver o pedido dentro dos prazos legais, o acusado poderá exigir pronta decisão, e, nesse caso, se dentro de vinte e quatro horas não obtiver uma decisão, entender-se-á que foi concedida a liberdade. Nesse caso, o tribunal ou juiz hierarquicamente superior lhe ordenará a liberdade".

499 Art. 142: “Quando a Corte Suprema de Justiça não resolver um recurso dentro dos prazos estabelecidos por este Código, entender-se-á que admitiu a solução proposta pelo recorrente, salvo se esta for desfavorável ao imputado, caso em que se entenderá que o recurso foi improvido. Se existirem recursos da várias partes, será adotada a solução proposta pelo imputado.

Quando o recurso se referir à cassação de uma sentença condenatória, antes de aplicar as regras precedentes, , se integrará uma nova Sala Penal dentro de três dias após o vencimento do prazo, que deverá resolver o recurso em um prazo não superior a 10 dias. 
$\mathrm{Na}$ Argentina, sempre que ultrapassado o prazo previsto para que uma decisão seja proferida, o interessado pode provocar a atuação jurisdicional requerendo pronta decisão. Se dentro do prazo de 3 dias não houver qualquer manifestação, poderá recorrer ao órgão superior, que deferirá o pedido correspondente. ${ }^{500}$

A seguir, a título de debate, serão propostas algumas alterações legislativas no Código de Processo Penal brasileiro, tendentes a conferir maior aplicabilidade e eficácia à garantia da razoável duração da persecução penal. Não será tratado o prazo de duração máxima da prisão cautelar, que não constitui objeto da presente dissertação, e que, por sua complexidade, demandaria ampla pesquisa, que mereceria ser abordada em trabalho autônomo $^{501}$.

\title{
7.2.1. Proposta de anteprojeto de lei
}

\author{
ANTEPROJETO N
}

Altera dispositivos do Decreto-Lei $\mathrm{n}^{\circ} 3.689$, de 3 de outubro de 1841 - Código de Processo Penal, relativos aos prazos processuais

O PRESIDENTE DA REPÚBLICA Faço saber que o Congresso Nacional decreta e eu sanciono a seguinte Lei:

Os Ministros da Corte Suprema de Justiça que tenham perdido sua competência por este motivo terão responsabilidade por mal desempenho de suas funções.

O Estado deverá indenizar o querelante quando tenha perdido seu recurso por este motivo, conforme o previsto neste capitulo".

${ }^{500}$ Art. 127: "Vencido o prazo no qual deveria ser proferida uma decisão, o interessado poderá pedir pronto despacho e, se dentro de 3 dias não o obtiver, poderá denunciar o atraso ao tribunal ao qual a autoridade judicial esteja submetida, o qual proverá o pedido correspondente. Se a demora for imputável ao presidente ou a um membro de um tribunal colegiado, a queixa poderá se formulada perante este mesmo tribunal; e, se fora imputável a este, poderá recorrer à Corte Suprema de Justiça, para que possa exercer os direitos que lhe são garantidos pela Constituição".

${ }^{501}$ A respeito do tema, destaca-se o trabalho de Roberto Delmanto, As modalidades de prisão provisória..., cit. O mesmo autor propõe, inclusive, anteprojeto de lei, visando regulamentar o prazo da prisão provisória em "Anteprojeto de Lei com vistas a impor celeridade ao processo, regulamentando o prazo da prisão provisória”, Revista Brasileira de Ciências Criminais, n 32, ano 8, dezembro de 2000, pp. 355-366. 
Art. $1^{\circ}$ Os arts. $6^{\circ}, 10,46,145,160,222,404,412,423,428$ e 537 do Decreto-Lei n ${ }^{\circ}$ 3.689, de 3 de outubro de 1941 - Código de Processo Penal, passam a vigorar com a seguinte redação, acrescentando-se os arts. 310-A, 316-A, 405-A, 405-B, 412-A, 428-A, 537-A, 580-A, 802-A, 802-B, 802-C e 802-D:

“Art. $6^{\circ}$ - A. Qualquer pessoa a quem, no curso do inquérito policial, for imputada a prática de infração penal, seja apontada como autora ou partícipe do fato, poderá exercer desde logo o direito de defesa, fazendo-se acompanhar de advogado em qualquer ato a que for chamada.

$\S 1^{\circ}$ Sem excluir outras hipóteses, presume-se a existência de imputação de infração penal contra o investigado:

I - quando for, por qualquer motivo, detido ou quando determinada a sua prisão cautelar;

II - quando sofrer medida de busca e apreensão, seqüestro, aresto, quebra de sigilo fiscal, interceptação telefônica, ou medida restritiva de qualquer natureza no curso do inquérito policial;

III - quando for apontado como provável autor em representação para a instauração de inquérito policial;

IV - quando a notícia de crime apontar seu nome como provável autor ou partícipe;

$\mathrm{V}$ - quando for interrogado perante a autoridade policial;

$\S 2^{\circ}$ Se o investigado não constituir advogado, ser-lhe-á nomeado um, para que acompanhe os atos do inquérito policial".

“Artigo 10. O inquérito policial deverá encerrar-se no prazo de 30 (trinta) dias, se o acusado estiver preso, e de 90 (noventa) dias, se estiver solto, contando-se o prazo a partir do momento em que for apontado como provável autor ou partícipe da infração penal, independentemente de qualquer ato formal nesse sentido. 
$\S 1^{\circ}$ Findo o prazo, a autoridade policial fará minucioso relatório do que tiver sido apurado até o momento e enviará os autos à autoridade judicial competente, requerendo, se for o caso, a prorrogação do prazo para a conclusão da investigação.

$\S 2^{\circ} \mathrm{A}$ autoridade judicial poderá autorizar, mediante decisão devidamente fundamentada, e por uma única vez, a prorrogação dos prazos previstos no caput por mais 30 (trinta) dias, nas seguintes hipóteses:

I - comprovada complexidade da causa;

II - elevado número de investigados;

III - dificuldade na localização de testemunhas ou da vítima;

IV - necessidade de conclusão de perícia ou exame já iniciados.

$\S 3^{\circ}$ Os laudos de perícias ou exames não concluídos nessa prorrogação, bem como os documentos colhidos depois dela, serão posteriormente remetidos ao juiz, para a juntada ao processo. Ainda, no seu relatório, deverá a autoridade policial mencionar, se possível, o lugar onde se encontram as testemunhas que deixaram de ser ouvidas, por qualquer impedimento.

$\S 4^{\circ}$ Se o Ministério Público não tiver elementos para formar sua opinião sobre o delito com base nos elementos até então colhidos no inquérito policial, poderá requerer novas diligências, desde que imprescindíveis ao oferecimento da denúncia, cabendo ao juiz fixar o prazo para a sua realização, que não poderá ultrapassar o prazo máximo de 10 (dez) dias em nenhuma hipótese.

$\S 5^{\circ}$ Se por qualquer motivo for desrespeitado o prazo máximo de duração do inquérito policial, será determinado o seu trancamento".

“Art. 16. (Revogado)".

“Art. 46. O prazo para oferecimento da denúncia, estando o réu preso será de 5 (cinco) dias, contado da data em que o órgão do Ministério Público receber os autos do inquérito 
policial, e de 15 (quinze) dias, se o réu estiver solto. Se houver devolução dos autos à autoridade policial, o prazo para o oferecimento da denúncia contar-se-á o prazo da data em que o órgão do Ministério Público receber novamente os autos.

$\S 1^{\mathrm{o}}$

$\S 2^{\circ}$

$\S 3^{\circ}$ Ultrapassado o prazo para o oferecimento da denúncia, se o Ministério Público permanecer inerte, o juiz fará a remessa dos autos do inquérito ao procurador-geral, que deverá, no prazo de 5 dias, manifestar-se oferecendo a denúncia, requerendo novas diligências nos termos do $\S 4^{\circ}$ do artigo 10 ou requerendo o arquivamento do feito.

$\S 4^{\circ}$ Ultrapassado o prazo de 5 (cinco) dias sem manifestação pelo procurador-geral, o juiz declarará extinto processo."

“Art. 145 .

$\mathrm{I}-$

II -

III - conclusos os autos, ordenará, no prazo de 5 (cinco) dias, as diligências que entender necessárias;

IV -

"Art. 160

Parágrafo único. O laudo pericial será elaborado no prazo máximo de 10 (dez) dias, podendo este prazo ser prorrogado, em casos excepcionais, e por uma única vez, pelo prazo máximo de $10(\mathrm{dez})$ dias, a requerimento dos peritos." 
“Art. 222. A testemunha que morar fora da jurisdição do juiz será inquirida pelo juiz do lugar de sua residência, expedindo-se, para esse fim, carta precatória, com prazo de até 30 (trinta) dias, intimadas as partes".

“Art. 310-A. Requerida a liberdade provisória, o pedido deverá ser apreciado no prazo máximo de 2 (dois) dias.

Parágrafo único. Ultrapassado o prazo sem manifestação por parte da autoridade judiciária, o investigado ou acusado será imediatamente posto em liberdade, expedindo-se alvará de soltura em seu favor."

“Art. 316-A. Requerida a revogação da prisão preventiva, o pedido deverá ser apreciado no prazo máximo de 2 (dois) dias.

Parágrafo único. Ultrapassado o prazo sem manifestação por parte da autoridade judiciária, o investigado ou acusado será imediatamente posto em liberdade, expedindo-se alvará de soltura em seu favor."

"Art. 404. Ordenada diligência considerada imprescindível, de ofício ou a requerimento da parte, a audiência será concluída sem as alegações finais.

$\S 1^{\circ}$ A diligência determinada será realizada no prazo de 20 (vinte) dias.

$\S 2^{\circ}$ Após concluída a diligência, as partes apresentarão, no prazo sucessivo de 5 dias, suas alegações finais, por memorial, e, no prazo de 10 (dez) dias, o juiz proferirá a sentença."

“Art. 405-A. Para a aferição do prazo razoável de duração do procedimento ordinário serão somados os prazos previstos individualmente em lei para a realização de cada um dos atos processuais que se fizerem necessários no caso concreto. 
$\S 1^{\text {a }}$ Ultrapassada a soma a que se refere o caput desse artigo, o juiz deverá se manifestar sobre a existência de justificativa razoável para a dilação do prazo, adotando as seguintes providências:

I - se justificável a dilação, fixar prazo razoável para a conclusão dos atos processuais faltantes.

II - se injustificável a dilação, declarar extinto o processo.

$\S 2^{\circ}$ Caracterizam justificativas razoáveis para a dilação do prazo previsto no caput:

I - a complexidade do caso;

II - a comprovada má-fé no comportamento da defesa para a dilação do prazo;

$\S 3^{\circ}$ Não caracterizam justificativa razoável para a dilação do prazo previsto no caput:

I - a paralisação injustificada do processo;

II - o excesso de feitos sob a responsabilidade do juízo;

III - a pluralidade de réus, quando viável o desmembramento do processo, nos termos do art. 80;

IV - a gravidade do crime.

$\S 4^{\circ} \mathrm{O}$ prazo a que se refere o presente artigo não é aplicável para fins de relaxamento da prisão cautelar, que não poderá superar o limite máximo de duração previsto em lei em nenhuma hipótese."

“Art. 405-B. O prazo de duração do procedimento ordinário não poderá ultrapassar em nenhuma hipótese o prazo de 1 (um) ano, contados do recebimento da denúncia (art. 399), até a prolação da sentença, sob pena de extinção do processo."

“Art. 412. Aplica-se à primeira fase do procedimento do tribunal do júri o disposto no artigo 405-A e parágrafos deste Código." 
“Art. 412-A. A primeira fase do procedimento do tribunal do júri deverá ser concluída no prazo de 1 (um) ano, contado do recebimento da denúncia (art. 399) até a decisão de pronúncia, impronúncia ou absolvição sumária, sob pena de extinção do processo.”

“Art. 423. No prazo de 5 (cinco) dias, o juiz presidente fará relatório sucinto, deliberando sobre os requerimentos de provas a serem produzidas ou exibidas no plenário do júri, e adotará as providências devidas.

I - (Revogado)

II - (Revogado)"

“Art. 428

$\S 1^{\circ}($ Revogado $)$

$\S 2^{\circ}$ (Revogado).”

“Art. 428-A. Ultrapassado o prazo de 1 (um) ano, a contar da decisão que pronunciou o acusado, a defesa poderá requerer ao Tribunal a inclusão do processo em pauta para julgamento dentro do prazo de 30 (trinta) dias.

Parágrafo único. Não ocorrendo o julgamento nesse prazo, o juiz declarará extinto o processo."

“Art. 537. Aplica-se ao procedimento sumário o disposto no art.405-A e parágrafos deste Código" 
“Art. 537-A. O prazo de duração do procedimento sumário não poderá ultrapassar em nenhuma hipótese o prazo de 280 (duzentos e oitenta dias), contados do recebimento da denúncia (art. 399), até a prolação da sentença, sob pena de extinção do processo”.

“Art. 580-A. Os recursos deverão ser julgados nos seguintes prazos, contados a partir da data da conclusão para julgamento:

I - em 3 meses, o recurso em sentido estrito;

II - em 6 meses, o recurso de apelação;

III - em 6 meses o recurso extraordinário;

IV - em 6 meses o recurso especial;

$\mathrm{V}-\mathrm{em} 3$ meses o agravo de instrumento.

$\S 1^{\circ}$ Ultrapassado o prazo para o julgamento do recurso, qualquer das partes poderá requerer ao juiz ou relator que a decisão seja proferida dentro do prazo de 20 (vinte) dias.

$\S 2^{\circ}$ Não sendo julgado o recurso nesse prazo, considerar-se-á:

I - provido o recurso, se interposto pela defesa;

II - improvido o recurso, se interposto pela acusação."

“Art. 802-A. O prazo para a realização de qualquer ato processual será de 5 (cinco) dias, sempre que a lei não dispuser de modo diverso".

“Art. 802-B. Nenhum processo criminal durará tempo superior a 4 (quatro) anos, contados do recebimento da denúncia até o trânsito em julgado.

$\S 1^{\circ}$ Ultrapassado por qualquer razão esse prazo, será devida indenização ao acusado, apurável em processo civil de reparação de danos. 
$\S 2^{\circ}$ A responsabilidade do Estado pela tempestividade da prestação jurisdicional é objetiva, presumindo-se sua negligência sempre que o processo for extinto com fundamento no excesso de prazo."

“Art. 802-C. A duração do procedimento não poderá superar o prazo previsto para a prescrição da ação penal, quando esta for inferior ao máximo previsto para o tipo do procedimento adotado".

“Art. 802-D. Os prazos estabelecidos nos arts. 10, 46, 580-A e 802-B, aplicam-se a toda legislação extravagante, e atingem igualmente os crimes considerados hediondos pela Lei 8.072/90."

Art. $2^{\circ}$ Esta Lei entra em vigor 60 (sessenta) dias após a data de sua publicação.

Art. $3^{\circ}$ Ficam revogados o art. 16 , os $\S \S 1^{\circ}$ e $2^{\circ}$ do art. 428 , e incisos I e II do art. 423 , do Decreto-lei no 3.689, de 3 de outubro de 1941 - Código de Processo Penal. 


\section{CONCLUSÕES}

1. Em decorrência do Estado Democrático de Direito, fundado na dignidade da pessoa humana, o poder estatal deve ser limitado, não apenas materialmente, mas também no tempo, de modo a não prejudicar o núcleo essencial dos direitos fundamentais assegurados pela Carta Magna.

2. Qualquer que seja a teoria da pena adotada é essencial que a sanção se aproxime temporalmente do delito cometido. Nenhum efeito é obtido sobre a personalidade de um indivíduo ou sob o sistema social quando a pena demora a ser aplicada. Nesse sentido, o Processo Penal, único instrumento que legitima a aplicação da pena pelo Estado (nulla poena sine judicio), deve apresentar duração razoável, de molde a não frustrar os fins da pena.

3. O Processo Penal contém, em si mesmo, uma vocação estigmatizante, de afastamento social e etiquetamento do indivíduo. Além disso, traz angústia à pessoa a ele submetida, pelo receio quanto ao resultado final do processo. Desta forma, a longa duração do processo contribui para a estigmatização social do acusado, além de interferir no próprio convencimento judicial. 
4. Sendo a restrição temporal da liberdade, o núcleo da pena privativa de liberdade. É de se concluir que, quanto maior for a duração do processo, estando o acusado preso cautelarmente, tanto maior será a pena processual por ele suportada, invertendo-se, na prática, o sentido do princípio da presunção de inocência.

5. Embora a prescrição possa significar, incidentalmente, um controle atípico do tempo de duração do processo, não é suficiente para garantir um processo rápido, especialmente porque vinculada à idéia de gravidade do crime. Em se tratando de crimes apenados com penas elevadas, praticamente nenhum controle de duração do processo é alcançado por meio da prescrição.

6. A partir do momento em que o Estado tomou para si o monopólio da Administração da Justiça, substituindo-se aos particulares, surgiu tanto para a coletividade quanto para cada indivíduo envolvido no processo, um direito subjetivo à prestação jurisdicional tempestiva.

7. Embora presente na antiguidade, a preocupação com a duração do processo se intensificou a partir da Segunda Guerra Mundial, coincidindo com os movimentos universais de positivação dos direitos humanos. A garantia da duração razoável do processo passou, então, a integrar os principais documentos internacionais de salvaguarda dos direitos fundamentais.

8. No Brasil, a garantia da razoável duração do processo decorria da leitura conjugada de outras garantias, destacadamente, do devido processo legal, do acesso à justiça, além de integrar a idéias de celeridade e eficiência. Com a edição do Decreto-Lei $n^{\circ}$ 27, de 26 de maio de 1982, o Pacto de São José da Costa Rica passou a integrar formalmente o ordenamento jurídico brasileiro, bem assim a garantia da razoável duração do processo, previsto em seu art. $7^{\circ}, n^{\circ} 5$. Finalmente, com a Emenda Constitucional $n^{\circ} 45$, passou a figurar no texto constitucional, no art. $5^{\circ}$, inciso LXXVIII.

9. Por compor-se de expressão de conteúdo vago e impreciso, como a razoabilidade, bem como por servir-se do conceito de prazo que depende de fixação de termo inicial e final para a sua contagem, a garantia da razoável duração do processo, tende a ser invocada como conceito standart, muitas vezes sendo utilizada como mecanismo retórico de justificação o excesso de prazo, alcançando o efeito inverso ao que buscava tutelar. Daí a necessidade de disciplina infra-constitucional a delimitar o seu conteúdo e alcance. 
10. Na ausência de regulamentação legal do prazo razoável da persecução penal, cabe ao Poder Judiciário a tarefa hermenêutica necessária à aplicação imediata da garantia. Para tanto, o recurso ao princípio da proporcionalidade pode ser de grande valia, mormente com o emprego dos critérios da adequação, necessidade e proporcionalidade em sentido estrito.

11. A garantia da razoável duração do processo alcança a persecução penal como um todo, incidindo desde a fase de investigação criminal, até a própria execução da pena.

12. Como marco inicial da contagem do prazo de duração da persecução penal, no sistema processual atual, desponta o momento da instauração do inquérito policial, com a notícia criminis. Considerando, todavia, a dificuldade para a determinação da autoria no curso da investigação criminal, melhor seria que o cômputo se iniciasse com a indicação de provável autor do delito, assim considerado todo aquele contra quem pesar imputação (em sentido amplo) de uma infração penal, independentemente de ato formal nesse sentido.

13. Diante do princípio da presunção de inocência, a garantia da razoável duração do processo deve alcançar até o trânsito em julgado da sentença, quando se esgota a prestação jurisdicional. Independentemente disso, cada fase do procedimento há de se mostrar célere e devidamente delimitada, impondo-se a previsão de duração máxima da fase investigativa, do procedimento perante o juízo de primeiro grau, bem como da fase recursal. Na execução penal, deve ser respeitada rigorosamente a pena aplicada como limite máximo de duração do processo. Os incidentes da execução penal devem, igualmente, ser apreciados em tempo razoável, garantindo-se o gozo dos direitos conquistados pelo preso.

14. Uma vez fixado o conteúdo e o alcance da garantia, a dificuldade maior repousa na sua aplicação em cada caso concreto, já que não foram previstos prazos globais de duração da persecução penal. Para tanto, são de grande utilidade prática alguns critérios aplicados em decisões do Tribunal Europeu de Direitos Humanos e da Corte Interamericana de Direitos Humanos, que analisam os motivos invocados como justificativa da demora com base nos seguintes fatores: complexidade do caso, comportamento do acusado e conduta das autoridades judiciais responsáveis pela condução do processo. 
15. A despeito da existência de critérios jurisprudenciais desenvolvidos para auxiliar na aferição de excesso de prazo para o término do processo, não há como defender-se, no Estado Democrático de Direito, a chamada "doutrina do não-prazo", segundo a qual não deve ser fixado um prazo máximo de duração do processo, bastando a verificação em cada caso concreto e, ad porteriori, se o procedimento criminal durou ou não um prazo razoável.

16. É imprescindível, por imposição do princípio da legalidade, que a duração máxima do processo seja fixada previamente em lei, retirando-se do Poder Judiciário a possibilidade de fixar discricionariamente os limites temporais de sua própria atuação.

\section{BIBLIOGRAFIA}

ABALOS, Raul Washington. Derecho Procesal Penal. Vol. 2. Mendoza: Ediciones Jurídicas Cuyo, [s.d.].

ALBANESE, Susana. La garantía del plazo razonable. In: Nueva Doctrina Penal. Buenos Aires, p. 171-173, 1999/A.

ALMEIDA JÚNIOR, A. e COSTA JÚNIOR, J. B. de O. Lições de medicina legal. 22. ed. rev. ampl. São Paulo: Companhia Editora Nacional, 1998.

ALTAVILlA, Enrico. Psicologia Giudiziaria: Il processo psicológico e la verità giudiziale. Vol. 1 e 2. 4. ed. agg. e acresc. Torino: Torinese, [s.d.].

ALVIM NETO, José Manuel de Arruda. O direito de defesa e a efetividade do processo: vinte anos após a vigência do código. In: Revista de Processo. $\mathrm{N}^{0}$ 79. São Paulo, jul./set. 1995.

ANDRADE, Christiano José de. Da prescrição em matéria penal. São Paulo: Revista dos Tribunais, 1979. 
ANDRADE, Fábio Martins. A garantia da razoável duração do processo no âmbito internacional. In: Informativo Jurídico Consulex. Ano 19. № 51. Brasília, 26 de dezembro de 2005.

ANJOS, Fernando Vernice dos. Limite máximo da prisão provisória e pena em perspectiva. In: Boletim do IBCCrim. Ano 13. N 154. São Paulo, setembro de 2005.

ARAÚJO, Carlos Maurício Lociks. Os princípios da proporcionalidade e da razoabilidade e seu campo de aplicação nos julgados do TCU. In: Revista do TCU. Ano 35. № 102. Brasília, out./dez. 2004.

ARAÚJO, Francisco Fernandes. Responsabilidade objetiva do Estado pela morosidade da justiça. Campinas: Copola Editora, 1999.

. Do Prazo razoável na prestação jurisdicional. Acesso em: 11/08/2005. Disponível eletronicamente em: http://Kplus.cosmo.com.br/materia.asp?co=15\&rv=Direito

ARAYA M. Saúl. La fijación jurisdiccional de plazo para terminar el procedimiento preparatorio. In: Revista de la Asociación de Ciencias Penales de Costa Rica. Ano 5. No 21. San José, outubro de 2003.

AZEVEDO, José Olivar. Fatores determinantes da efetividade do processo: celeridade e imparcialidade. In: Revista Jurídica Consulex. Ano 16. № 134. Brasília, 15 de agosto de 2002.

BADARÓ, Gustavo Henrique Righi Ivahy. Direito Processual Penal: tomo I. Rio de Janeiro: Elsevier, 2008.

BALTAZAR, Antonio Lopes. Prescrição penal: prescrição da pretensão punitiva, intercorrente antecipada, da pretensão executória, da pena de multa, das penas restritivas de direito, direito comparado. Bauru: Edipro, 2003.

BARBOSA, Rui. Oração aos moços/ O dever do advogado. 2. ed. Campinas: Russell, 2005. 
BARROS, Suzana de Toledo. O princípio da proporcionalidade e o controle de constitucionalidade das leis restritivas de direitos fundamentais. 3. ed. Brasília: Brasília Jurídica, 2003.

BARRUFFINI, Frederico Liserre. Possibilidade de efetivação do direito à razoável duração do processo. In: Revista de Processo. Ano 31. No 139. São Paulo, setembro de 2006.

BÁRTOLI, Macio. O critério da razoabilidade. In: Revista Brasileira de Ciências Criminais. Ano 1. No 3. São Paulo, jul./set. 1993.

BARTOLOMÉ, Plácido Fernandez-Viagas. El derecho a un proceso sin dilaciones indebidas. Madrid: Civitas, 1994.

BECCARIA, Cesare Bonesana Marchesi di. Dos delitos e das penas. 5. reimp. Trad. Flório de Angelis. Bauru: Edipro, 2000.

BELLA, Gabriela Maria. El plazo de los años de art. 283, inc. 4º del Código Procesal Penal de Córdoba, constituye un límite infranqueable a la duración del encarcelamiento cautelar? In: Nueva Doctrina Penal. No 341. Buenos Aires, 2004.

BIDART, Adolfo Gelsi. El tiempo y el proceso. In: Revista de Processo. Vol. 6. No 23. São Paulo, 1991.

BOBBIO, Norberto. A Era dos Direitos. Trad. Regina Lyra. Rio de Janeiro: Elsevier, 2004.

BOLLE, P. H. Les lenteurs de la procédure pénale. In : Revue de Science Criminelle et de Droit Pénal Comparé. Nº 1. Paris, jan./mars. 1982.

BOLQUE, Fernando César. A efetividade dos direitos fundamentais (art. $5^{\circ}$ da Constituição Federal) e o princípio da razoabilidade das leis: a atuação do Ministério Público. In : Justitia. Ano 62. Vol. 189/192. São Paulo, jan./dez. 2000.

BONICIO, Marcelo José Magalhães. Proporcionalidade e processo: a garantia constitucional da proporcionalidade, a legitimação do processo civil e o controle das decisões judiciais. São Paulo: Atlas, 2006.

BOTELHO, Afonso Henrique Castrioto. A sumarização razoável do processo. In: Revista da EMERJ. Vol. 10. N 37. Rio de Janeiro, 2007. 
BOULOC, Bernard. La durée des procédures: un délai en fin raisonnable? In : Revue de Science Criminelle et de Droit Pénal Comparé. [s.n.] Paris, jan./mar. 2001.

BRAGA, Valeschka e Silva. Princípios da proporcionalidade e razoabilidade. Curitiba: Juruá, 2004.

BRANCO, Luiz Carlos. Eqüidade, proporcionalidade, e razoabilidade: doutrina $e$ jurisprudência. São Paulo: RCS Editora, 2006.

BUCCI, Maria Paula Dallari. O princípio da razoabilidade em apoio à legalidade. In : Revista Brasileira de Ciências Criminais. Ano 4. No 16. São Paulo, jul./set. 1996.

BUSTAMANTE, Thomas da Rosa de. Conceito e critérios de razoabilidade : uma proposta para o direito brasileiro. In : Direito, Estado e Sociedade. № 27. Rio de Janeiro, 2005.

CAFFERATA NORES, José I. Proceso penal y derechos humanos: la influencia de la normativa supranacional sobre derechos de nivel constitucional en el proceso argentino. Buenos Aires: Editores del Puerto, 2000.

. e MONTEIRO, Jorge R. El imputado: estudios. Córdoba: Mediterránea, 2004.

CAMARGO, Antonio Luis Chaves. Sistema de penas, dogmática jurídico-penal e política criminal. São Paulo: Cultural Paulista, 2002.

CAMARGO, Margarida Maria Lacombe. O princípio da proporcionalidade sob uma perspectiva hermenêutica e argumentativa. In: Revista do Instituto de Hermenêutica Jurídica. Vol. 1. № 3. Porto Alegre, 2005.

CAMPOS, Amini Haddad. O devido processo proporcional: o princípio da proporcionalidade constitucional na teoria processual: as concepções do direito brasileiro. São Paulo: Lejus, 2001.

CANOTILHO, J.J. Gomes. Direito Constitucional e Teoria da Constituição. 5. ed. Coimbra: Almedina, [s./d.]. 
CARNELUTTI, Francesco. Leciones sobre el proceso penal. Trad. Santiago Sentis Melendo. Buenos Aires: Bosch, [s./d.].

. As misérias do processo penal. Trad. José Antonio Cardinalli. São Paulo?: Conan, 1995.

CARRARA, Francesco. Programa del curso de derecho criminal dictado en la Real Universidad de Pisa. Vol. I. Parte Geral. Buenos Aires: Depalma, 1944.

CARVAlHAL, Nelson Antonio Celani. Considerações sobre o conceito de "prazo razoável” no direito brasileiro. In: Revista Jurídica Consulex. Ano 1. № 5. Brasília, 31 de maio de 1997.

CARVALHO, Michelle Aurélio de. Flexibilidade da inadmissibilidade das provas ilícitas. In: Revista da Faculdade de Direito de Campos. Ano 6. $\mathrm{N}^{\mathrm{o}}$ 6. Campos dos Goitacases, junho de 2005.

CARVAlHO FILHO, Aloysio de Carvalho Filho, Comentários ao Código Penal. Vol. IV. Rio de Janeiro: Forense, [s./d.].

CASTRO, Carlos Roberto de Siqueira. O devido processo legal e a razoabilidade das leis na nova Constituição do Brasil. Rio de Janeiro: Forense, 1989.

CATARINO, Luís Guilherme. A responsabilidade do Estado-juiz? (alguns aspectos a propósito dos 'casos' Lowry e Assento n 1/99). In: Revista do Ministério Público. Ano 20. No 77. Lisboa, jan-mar. 1999.

. Contributo para uma reforma do sistema geral de responsabilidade civil extracontratual do Estado - propostas acerca da imputação por fato jurisdicional. In: Revista do Ministério Público. Ano 22. № 88. Lisboa, out./dez. 2001.

CAVALLI, Cássio Machado. A compreensão jurídica do dever de razoabilidade. In: Revista de Direito Constitucional e Internacional. Ano 13. N ${ }^{o}$ 50. São Paulo, jan./mar. 2005.

CEBALlOS, Elena B. Marin de Espinosa. La reparación de las dilaciones indebidas en el proceso penal. In: Cuadernos de Política Criminal. № 70. Madrid, 2000. 
CHAGAS, Fernando Cerqueira. A relação entre o princípio da proporcionalidade (razoabilidade) e a interpretação conforme a Constituição no Estado Democrático de directo. In: ANDRADE, André Gustavo Correia (org.). A Constitucionalização do Direito: a Constituição como locus da hermenêutica jurídica. Rio de Janeiro: Lumen Juris, 2003.

CHOUKR, Fauzi Hassan. Garantias constitucionais na investigação criminal. 2. ed. Rio de Janeiro: Lumen Juris, 2001.

CIANCIARDO, Juan. El principio de razonabilidad - del debido proceso sustantivo al moderno juicio de proporcionalidad. Buenos Aires: Ábaco de Rodolfo Desalma, 2004.

CINTRA, Antônio Carlos de Araújo; GRINOVER, Ada Pellegrini; DINAMARCO, Cândido Rangel. Teoria Geral do Processo. 17. ed. São Paulo: Malheiros, 2001.

COSTA JR., Paulo José da. Direito Penal: curso completo. 6. ed. São Paulo: Saraiva, 1999.

CRUZ E TUCCI, José Rogério. Garantia da prestação jurisdicional sem dilações indevidas como corolário do devido processo legal. In: Revista de Processo. Vol. 17. N 66. São Paulo, abr./jun. 1992.

. Tempo e processo. São Paulo: Revista dos Tribunais, 1997.

. Garantia do processo sem dilações indevidas. In: Garantias constitucionais do processo civil. 2. ed. São Paulo: Revista dos Tribunais, 1999.

. Garantia do processo sem dilações indevidas: responsabilidade do Estado pela intempestividade da prestação jurisdicional. In: Revista da Faculdade de Direito da USP. Vol. 97. São Paulo, 2002.

DÁlIA, Andréa Antonio; FERRAIOLI, Marzia. Manuale di diritto processuale penale. 4. ed. [S./1.]: Cedam, 2001.

DANTAS, F.C. de. Igualdade perante a lei e due process of law: contribuição ao estudo da limitação constitucional do Poder Legislativo. In: Revista Forense. Ano 45. Vol. 116. F. 537. Rio de Janeiro, março de 1948. 
DEL ROSAL, Manuel Cobo; QUINTANAR DÍEZ, Manuel; LOPÉZ GOMÉZ, Carlos Zaballa. Derecho procesal penal español (totalmente actualizado). Madrid: CESEJ, 2006.

DELMANTO JÚNIOR, Roberto. As modalidades de prisão provisória e seu prazo de duração. Rio de Janeiro: Renovar, 1998.

. "Anteprojeto de Lei com vistas a impor celeridade ao processo,regulamentando o prazo da prisão provisória”. In: Revista Brasileira de Ciências Criminais. Ano 8. No 32. São Paulo, dezembro de 2000.

DEZEM, Guilherme Madeira e JUNQUEIRA, Gustavo Octaviano Diniz. "Prazo para encerramento do procedimento". In: Boletim do IBCCrim. Ano 16. No 188. São Paulo, julho de 2008.

DIAS, Jorge de Figueiredo; ANDRADE, Manuel da Costa. Criminologia: o homem delinqüente e a sociedade criminógena. Coimbra: Coimbra, 1997.

DINAMARCO, Cândido Rangel. A instrumentalidade do processo. 7. ed. São Paulo: Malheiros, 1999.

DUVILLIER, Thibaut. Celeridad y proatividad. Visión crítica sobre los procedimientos de justicia acelerada. In: Cuadernos de Doctrina y Jurisprudencia Penal. Ano 8. № 14. Buenos Aires, 2002.

DWORKIN, Ronald. Levando os direitos a sério. Trad. Nelson Boeira. São Paulo: Martins Fontes, 2002.

FALLETTI, Elena. Il dibattito sulla ragionevole durata del processo tra la Corte Europea dei Diritti dell'Huomo e lo Stato italiano. In: Revista da AJURIS. Ano 33. No 101. Porto Alegre, março de 2006.

FERNANDES, Antonio Scarance. Processo Penal Constitucional. 3. ed. São Paulo: Revista dos Tribunais, 2002.

. "Efetividade, processo penal e dignidade humana". In: MIRANDA, Jorge e SILVA, Marco Antonio Marques da (coord.). Tratado luso-brasileiro da dignidade humana. São Paulo: Quatier Latin, 2008. 
. "Reflexões sobre as noções de eficiência e garantismo no processo penal”. In: FERNANDES, Antonio Scarance; ALMEIDA, José Raul Gavião de; MORAES, Maurício Zanoide de (coords.). Sigilo no processo penal: eficiência e garantismo. São Paulo: Revista dos Tribunais, 2008.

FERRAJOLI, Luigi. Diritto e ragione: teoria del garantismo penale. 7. ed. Roma: Laterza, 2002.

FERRARI, Eduardo Reale. Prescrição penal: suas causas suspensivas e interruptivas. São Paulo: Saraiva, 1998.

- Código de Processo Penal: comentários aos projetos de reforma legislativa. Campinas: Millenium, 2003.

FERRAZ JÚNIOR, Tércio Sampaio. Introdução ao estudo do Direito: técnica, decisão, dominação. 2. ed. São Paulo: Atlas, 1994.

. Direito Constitucional: liberdade de fumar, privacidade, estado, direitos humanos e outros temas. Barueri: Manole, 2007.

FIGUEIREDO, Sylvia Marlene de Castro. A interpretação constitucional e o princípio da proporcionalidade. São Paulo: RCS Editora, 2005.

FOCARELLI, Carlo. La legge Pinto e l' applicabilità del dirrito alla durata ragionevole del processo alle indagini preliminari e ai giudizi tributari. In: Giurisprudenza Costituzionale. Ano 50. No 6. Milano, nov./dez. 2005.

FRAGOSO, Heleno Cláudio. Lições de Direito Penal - Parte Geral. 16. ed. Atualizado por Fernando Fragoso. Rio de Janeiro : Forense, 2004.

FRANCO, Alberto Silva. Crimes Hediondos: anotações sistemáticas à lei 8.072/90. 3. ed. São Paulo: Revista dos Tribunais, 1994.

. Prazo razoável e o Estado Democrático de Direito. In: Boletim IBCCrim. Vol. 13. No 152. São Paulo, julho de 2005.

FRANCO FILHO, Georgenor. Reengenharia do processo: produtividade e celeridade. In: Revista LTR. Ano 70. N 4. São Paulo, abril de 2006. 
FREITAS, Luiz Fernando Calil de. Direitos fundamentais: limites e restrições. Porto Alegre: Livraria do Advogado, 2007.

FREITAS FILHO, Roberto. Estudos Jurídicos Críticos (CLS) e coerência das decisões. In: Revista de Informação Legislativa. Ano 44. N 175. Brasília, jul./set. 2007.

GAJARDONI, Fernando da Fonseca. O princípio constitucional da tutela jurisdicional sem dilações indevidas e o julgamento antecipadíssimo da lide. In: Revista de Processo. Ano 31. No 141. São Paulo, novembro de 2006.

GARCIA, Basileu. Instituições de Direito Penal. Vol. I. Tomo II. São Paulo: Max Limonad, 1952.

GENIN-MERIC, Régine. Être jugé dans um delais raisonnable: reflexions sur le contôle de la recevabilité de l'action publique. In: Revue de Science Criminelle et de Droit Penal Comparé. № 1. Paris, jan./mar. 1980.

GIORGIS, José Carlos Teixeira. O prazo razoável como conceito indeterminado no processo penal. In : FAYET JR., Ney; WEDI, Miguel Tedesco (orgs.). Estudos críticos de direito e processo penal em homenagem ao Des. Garibaldi Almeida Wedi. Porto Alegre : Livraria do Advogado, 2004, p. 111-121.

GOMES, Mariângela Gama de Magalhães. O princípio da proporcionalidade no Direito Penal. São Paulo: Revista dos Tribunais, 2003.

GOMES FILHO, Antonio Magalhães. Presunção de inocência e prisão cautelar. São Paulo: Saraiva, 1991.

. Direito à prova no processo penal. São Paulo: Revista dos Tribunais, 1997. A motivação das decisões penais. São Paulo: Revista dos Tribunais, 2001.

GORPHE, François. La critique du témoignage. 2. ed. Paris: Dalloz, 1927.

GRAU, Eros Roberto. (prefácio). In: Pontes, Helenilson Cunha Pontes. O princípio da proporcionalidade e o direito tributário. São Paulo: Dialética, 2000. 
. Eqüidade, razoabilidade e proporcionalidade. In: Revista do Advogado. Ano 24. No 78. São Paulo, setembro de 2004.

. Eqüidade, razoabilidade, proporcionalidade e princípio da moralidade. In:

Revista do Instituto de Hermenêutica Jurídica. Vol. 1. No 3. Porto Alegre, 2005.

GRAVATÁ, Isabelli. O procedimento sumaríssimo na contramão da celeridade processual. In: Revista Consulex. Ano 10. № 229. Brasília, 31 de julho de 2006.

GRECO FILHO, Vicente. Manual de Processo Penal. 6. ed. São Paulo: Saraiva, 1999.

GRINOVER, Ada Pellegrini; FERNANDES, Antonio Scarance; GOMES FILHO, Antonio Magalhães. As nulidades no processo penal. 9. ed. São Paulo: Revista dos Tribunais, 2006.

GRONEMAN, Ray; SCHWARZENBERGER, Suzan; WILlOUGHBY, Stephen. The right to a speedy trial: a case study of the St. Louis Criminal Docket. In: Saint Louis University Law Journal. Vol. 16. № 1. Saint Louis, 1991.

GUAZZALOCA, Bruno et al. Controllo di ragionevolezza e sistema penale. In: Dei Delitti e Delle Penne. Ano 5. N 1. Napoli, jan./abr. 1998.

GUERRA, Sérgio. O princípio da proporcionalidade na pós-modernidade. In: Revista Brasileira de Direito Público. Ano 1. No 3. Belo Horizonte, out./dez. 2003.

GUINALZ, Ricardo Donizete. Princípio da proporcionalidade e o processo penal. 2002. Dissertação de mestrado - Faculdade de Direito, Universidade de São Paulo, São Paulo, 2002.

HOBBES, Thomas. Leviatã ou Matéria, Forma e Poder de um Estado Eclesiástico e Civil. Trad. João Paulo Monteiro e Maria Beatriz Nizza da Silva. São Paulo: Nova Cultural, 1999.

INTERNATIONAL, AMNESTY. Processo '7 aprile' - Italida. Motivi di preoccupazione di Amnesty International riguardo a un processo equo entro un termine ragionevole. In: Dei Delitti e Delle Pene. Ano 5. N² 2. Napoli, mai./ago. 1987. 
JAKOBS, Günther. "Imputación jurídicopenal: desarrollo del sistema a partir de las condiciones de vigência de la norma”. In: Problemas Capitales del Derecho Penal Moderno. Trad. Javier Sánchez - Vera Gomes - Trelles. Buenos Aires: Hamurabi, 1998.

JESUS, Damásio Evangelista de. Prescrição penal. 8 ed. São Paulo: Saraiva, 1994.

JIMÉNEZ, Hugo Vinícius Castro. A globalização e os princípios da proporcionalidade e da razoabilidade. In: Revista da ESMAPE. Vol. 10. № 22. Recife, jul./dez. 2005.

LA ROSA, Mariano R. La duración del proceso penal. In: Cuadernos de Doctrina y Jurisprudencia Penal. Vol. 8. No 14. Buenos Aires, dezembro de 2002.

LIMA, Marcellus Polastri. Provas lícitas ou ilícitas: considerações sobre a admissibilidade da prova vedada no processo penal brasileiro. In: Revista Síntese de Direito Penal e Processual Penal. Ano 4. No 24. Porto Alegre, fev./mar. 2004.

LOCKE, JOHN. Segundo Tratado sobre o governo civil: ensaio sobre a origem, os limites e os fins verdadeiros do governo civil. Trad. Magda Lopes e Marisa Lobo da Costa. Petrópolis: Vozes, 1994.

LOPES, Manoel. Senões da EC n ${ }^{0}$ 45. In: Correio Brasiliense, Brasília, 8 de agosto de 2005.

LOPES JÚNIOR, Aury. Processo penal, tempo e risco: quando a urgência atropela as garantias. In: BONATO, Gilson (org.). Processo Penal: leituras constitucionais. Rio de Janeiro: Lumen Juris, 2003.

. Sistemas de investigação preliminar no processo penal. 2. ed. Rio de Janeiro: Lumen Juris, 2003.

A (de) mora jurisdicional no processo penal: o direito a um processo sem dilações indevidas. In: Revista de Estudos Criminais. Ano 4. N ${ }^{0}$ 15. Porto Alegre, 2004.

O direito de ser julgado em um prazo razoável: o tempo como pena e a (de) mora jurisdicional no processo penal. In: Revista da Associação Brasileira de Professores de Ciências Penais. Ano 1. São Paulo, jul./dez. 2004. 
. O tempo como pena processual: em busca do direito de ser julgado em um prazo razoável. In: Andrei Zenkner Schmidt (coord.). Novos rumos do Direito Penal contemporâneo: livro em homenagem ao prof. Dr. Cezar Roberto Bitencourt. Rio de Janeiro: Lumen Juris, 2006.

. Direito processual penal e sua conformidade constitucional. Vol. I. 3. ed. Rio de Janeiro: Lumen Juris, 2008.

. “Bom para quê(m)?”. In: Boletim IBCCrim. Ano 188. N 16. São Paulo, julho de 2008.

. e BADARÓ Gustavo Henrique Righi Ivahy. Direito ao processo penal no prazo razoável. Rio de Janeiro: Lumen Juris, 2006.

LUCON, Paulo Henrique dos Santos. O controle dos atos executivos e a efetividade da execução: análises e perspectivas. In: Teresa Assuda Alvim Wambier (coord.). Processo de execução e assuntos afins. São Paulo: Revista dos Tribunais, 1998.

MACHADO, Agapito. A nova reforma do Poder Judiciário. In: Revista da AJUFE. Ano 23. Campinas, $1^{\mathrm{o}}$ semestre de 2005.

MACHADO, Fabio Guedes de Paula. Prescrição penal: Prescrição funcionalista. São Paulo: Revista dos Tribunais, 2000.

MAIER, Julio B. J. Es posible todavia la realización del proceso penal en el marco de un Estado de Derecho? In: Revista de Ciencias Jurídicas Más Derecho? No 1. [S./1.], 2000 .

. Derecho procesal penal. Tomo I: Parte General. Buenos Aires: Del Puerto, 2003.

. Derecho procesal penal. Tomo II: Fundamentos. Buenos Aires: Del Puerto, 2003.

MAMMONE, Giovanni. La legge sull' equa riparazione per violazione del diritto alla ragionevole durata del processo. In: Giustizia Civile. Vol. 52. № 9. Milano, setembro de 2002. 
MANZINI, Vincenzo. Trattato di Dirito Processuale Penale Italiano. 6 ed. Torino: Torinense, [s./d.].

MARCACINI, Augusto Tavares Rosa. Estudo sobre a efetividade do processo civil. 1999. Tese de doutorado - Faculdade de Direito, Universidade de São Paulo, São Paulo, 1999.

MARCHISIO, Adrián. El juicio abreviado y la instrucción sumaria - procedimiento penal nacional y derecho comparado. Buenos Aires: Ad - Hoc, 1998.

MARIA BELLA, Gabriela. Le plazo de dos años del art. 283, inc. $4^{\circ}$, del Código Procesal Penal de Córdoba, constituye un limite infranqueable a la duración del encarcelamiento cautelar? In: Nueva Doctrina Penal. [s./n.]. Buenos Aires, 2004.

MARINONI, Luiz Guilherme. Efetividade do processo e tutela antecipatória. In: Revista dos Tribunais. Vol. 83. No 706. São Paulo, 1994.

MARQUES, José Frederico. Elementos de Direito Processual Penal. Rio de Janeiro: Forense, 1961.

MATTOS, Mauro Roberto Gomes de. Da Emenda Constitucional n 45/2004 e seu reflexo jurídico no direito fundamental do prazo razoável para a duração de processo administrativo disciplinar: inconstitucionalidade do $\S 1^{\circ}$, do artigo 169 da Lei 8.112/90. In: Justiça do Trabalho. Ano 23. № 265. Porto Alegre, janeiro de 2006.

MAXIMILIANO, Carlos. Hermenêutica e aplicação do direito. 6. ed. São Paulo: Livraria Freitas Bastos, 1957.

MEDINA, Paulo Roberto de Gouveia. Emenda $n^{\circ} 45 / 2004$ e o direito processual constitucional. In: Revista da Ordem dos Advogados do Brasil. Ano 35. № 80. Rio de Janeiro, jan./jul. 2005.

MELlo, Celso Antônio Bandeira de. Curso de Direito Administrativo. 22. ed. São Paulo: Malheiros, 2007.

MELO, Gustavo de Medeiros. A tutela adequada na reforma constitucional de 2004. In: Revista de Processo. Ano 30. No 124. São Paulo, junho de 2005. 
MENDES, Gilmar Ferreira. Pressupostos de admissibilidade do controle abstrato de normas perante a Corte Constitucional alemã: Bundesverfassungsgericht. In: Arquivos do Ministério da Justiça. Ano 47. N 134. Brasília, jul./dez. 1994.

. O princípio da proporcionalidade na jurisprudência do Supremo Tribunal Federal: novas leituras. In: Repertório IOB de Jurisprudência: Tributário, Constitucional e Administrativo. № 14. São Paulo, julho de 2000.

MESSUTI, Ana. O tempo como pena. São Paulo: Revista dos Tribunais, 2003.

MIGUEL, João Manuel da Silva. Tribunal Europeu dos Direitos do Homem: caso Torrado contra Portugal, decisão de 22 de maio de 2003. In: Revista do Ministério Público. Ano 24. No 95. Lisboa, jul./set. 2003.

MIRABETE, Júlio Fabbrini. Processo Penal. 18. ed., revista e atualizada por Renato N. Fabbrini. São Paulo: Atlas, 2006.

MIRANDA, Jorge. Manual de Direito Constitucional. Vol. 2. 2. ed. Coimbra, 1983.

MOMMSEN, Theodor. Derecho penal romano. Bogotá: [s./e.], 1991.

MORAES, Maurício Zanoide. Presunção de inocência no processo penal brasileiro: análise de sua estrutura normativa para a elaboração legislativa e para a decisão judicial. Tese de livre-docência. São Paulo: Universidade de São Paulo, 2008.

MOREIRA, José Carlos Barbosa. Notas sobre alguns aspectos do processo (civil e penal)

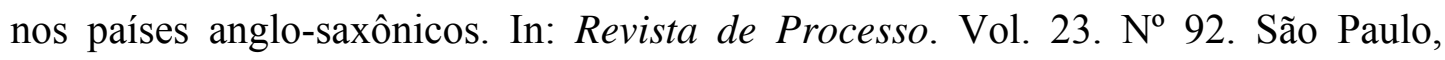
out./dez. 1998.

MORO, Luis Carlos. “Onde está a razoabilidade - como se pode definir a 'razoável duração do processo"”. Disponível eletronicamente em: http://conjur. estadao.com.br/static/text/32536,I. Com acesso em: 11/08/2005.

MOURA, Maria Thereza Rocha de Assis. A prova por indícios no Processo Penal. Saraiva: São Paulo, 1994.

e LACAVA, Thaís Aroca Datcho. "A garantia da razoável duração do processo penal e a contribuição do STJ para a sua efetividade”. In: PRADO, Geraldo 
e MALAN, Diogo (coord.). Processo Penal e Democracia: Estudos em Homenagem aos 20 anos da Constituição da República de 1988. Rio de Janeiro: Lumen Juris, 2009.

. e PITOMBO, Cleunice A. Valentim Bastos. Defesa penal: direito ou garantia. In: Revista Brasileira de Ciências Criminais. Vol. 1. No 4. São Paulo, out./dez. 1993.

NADDEO, Cecília Cristina. Cuestiones prejudiciales. In: Nueva Doctrina Penal. [s./n.]. Buenos Aires, 2003/B.

NADER NETO, Jorge Miguel. O implacável chronos, o Direito e a Justiça. In: Revista Síntese de Direito Penal e Processo Penal. Ano 5. N 30. São Paulo, fev./mar. 2005.

NALINI, José Roberto. "Duração razoável do processo e a dignidade da pessoa humana". In: MIRANDA, Jorge e SILVA, Marco Antonio Marques da (coord.). Tratado lusobrasileiro da dignidade humana. São Paulo: Quatier Latin, 2008.

NOHARA, Irene Patrícia. Limites à razoabilidade nos atos administrativos. São Paulo: Atlas, 2006.

NORONHA, E. Magalhães. Curso de Direito Processual Penal. 28. ed. Atualizada por Adalberto Q. T. de Camargo Aranha. São Paulo: Saraiva, 2002.

NICOLITT, André Luiz. A duração razoável do processo. Rio de Janeiro: Lumen Juris, 2006.

NUCCI, Guilherme de Souza. Código de Processo Penal Comentado. São Paulo: Revista dos Tribunais, 2002.

OLIVEIRA, José Roberto Pimenta. Os Princípios da razoabilidade $e$ da proporcionalidade no Direito Administrativo brasileiro. São Paulo: Malheiros, 2006.

OLIVEIRA, Pedro Miranda de. O direito à razoável duração do processo à luz dos direitos humanos e sua aplicação no Brasil. In: Jurisprudência Catarinense. Ano 31. № 107. Florianópolis, $2^{\circ}$ trimestre de 2005. 
OLIVEIRA, Roberto da Silva. “A dignidade da pessoa humana, a razoável duração do processo e a cooperação internacional penal: a experiência luso-brasileira". In: MIRANDA, Jorge e SILVA, Marco Antonio Marques da (coord.). Tratado lusobrasileiro da dignidade humana. São Paulo: Quatier Latin, 2008.

O’DWYER, Edson. O juiz, os prazos e o processo penal. In: Fascículos de Ciências Penais. Ano 6. No 6. Porto Alegre, jan./mar. 1993.

PAES, Sara Maria Ströher. Direito a ser ouvido em um prazo razoável: morosidade da justiça segundo a ótica do Tribunal Europeu de Direitos Humanos. In: Revista de Informação Legislativa. Ano 34. N 135. Brasília, jul./set. 1997.

PAGLIUCA, José Carlos Gobbis. Flashes penais e os prazos processuais com a Emenda ${ }^{\circ}$ 45. In: Boletim do IBCCrim. Ano 13. N 150. São Paulo, maio de 2005.

PASTOR, Daniel R. El plazo razonable en el proceso del Estado de Derecho: una investigación acerca del problema de la excesiva duración del proceso penal y sus posibles soluciones. Buenos Aires: Ad-Hoc, Honrad-Adenauer Stiftung, 2002.

. Acerca del derecho fundamental al plazo razonable de duración del proceso penal. In: Revista Brasileira de Ciências Criminais. № 52. São Paulo, jan./fev. 2005.

PEIXOTO, Alexandre Sivolella; QUEIROZ, Taísa; MENDES, Fábio Carvalho. O princípio da razoabilidade. In: Revista Jurídica UNIGRAN. Vol. 6. N 11. Dourados, jan./jun. 2004.

PENTEADO, Jacques de Camargo. Tempo da prisão: breves apontamentos. In: Revista da Faculdade de Direito de São Bernardo do Campo. Ano 6. № 8. São Paulo, 2002.

PEREIRA, Thaís Aroca Datcho. A valoração do reconhecimento de pessoas no processo penal brasileiro. 2004. Tese de Láurea - Faculdade de Direito, Universidade de São Paulo, São Paulo, 2004.

PÉREZ LUÑO, Antonio Enrique. Derechos Humanos, Estado de Derecho y Constitución. 8. ed. Madrid: Tecnos, 2003.

PETRY JÚNIOR, Henry. Considerações sobre os princípios constitucionais da proporcionalidade e da razoabilidade e sua (in) aplicabilidade às condutas previstas 
no art. 73 da Lei 9.504/1997. In: Revista Jurídica do Ministerio Público Catarinense. Vol. 4. No 8. Florianópolis, jan./abr. 2006.

PINTAÚDE, Gabriel. Proporcionalidade como postulado esencial do Estado de Direito. In: Revista Forense. Ano 102. Vol. 387. Rio de Janeiro, set./out. 2006.

PINTO, Alexandre Guimarães Gavião. A prova ilícita e o princípio da proporcionalidade dos valores contrastantes. In: Revista da EMERJ. Vol. 8. N 32. Rio de Janeiro, 2005.

PIOVESAN, Flávia. Direitos Humanos e o Direito Constitucional Internacional. 7. ed. São Paulo: Saraiva, 2006.

PITOMBO, Antonio Sérgio Altieri de Moraes (org.). Juizados Especiais Criminais Interpretação crítica. São Paulo: Malheiros, 1997.

PITOMBO, Sérgio Marcos de Moraes. Inquérito policial: novas tendências. Belém: CEJUP, 1987.

PORFÍRIO, Geórgia Bajer Fernandes de Freitas; FERNANDES, Paulo Sérgio Leite. Prescrição Penal: aspectos clássicos. Inovações trazidas por leis extravagantes. Hipóteses e circunstâncias pouco analisadas pela dogmática e pela jurisprudência. In: Revista da Associação dos Juízes Federais do Brasil. Ano 18. № 62. [s./1.], jul./set. 1999.

PORTO, Antonio Rodrigues. Da prescrição penal. 2. ed. São Paulo: Bushatsky, 1977.

POZZA, Pedro Luiz. Devido processo legal e suas acepções. In: Revista da AJURIS. Ano 33. No 191. Porto Alegre, março de 2006.

PRADO, Fabiana Lemes Zamalloa do. A ponderação de interesses em matéria de prova no processo penal. São Paulo: IBCCrim, 2006.

PRIETO RODRÍGUEZ, Javier Ignácio. Hacia una reinterpretación de la prescripción penal”. In: Actualidad Penal: Revista Semanal Técnico-Jurídica de Derecho Penal. No 20. F. 1. Madrid, 1998. 
RAMÍREZ, Luís; SECAIDA, Patrícia. La duración de procesos penales en Guatemala: un análisis empírico. In: Revista Centro Americana - Justicia Penal y Sociedad. [s./n.]. Guatemala, 2001.

RAMOS MÉNDEZ, Francisco. El Proceso penal - lectura constitucional. Barcelona: Bosch, 1991.

REALE JÚNIOR, Miguel. Instituições de direito penal: Parte Geral. Rio de Janeiro: Forense, 2002.

RIBEIRO FILHO, João Costa. A lógica do razoável ou lógica humana. In: Direito em Ação. Vol. 5. No 2. Brasilia, dezembro de 2004.

RODRIGUES, Anabela Miranda. Os processos sumário e sumaríssimo ou a celeridade e o consenso no Código de Processo Penal. In: Revista Portuguesa de Ciência Criminal. Ano 6. No 36. Coimbra, jul./set. 1996.

RODRIGUES, Rebeca Mignac de Barros. Do princípio da proporcionalidade e sua aplicação quanto à utilização de provas ilícitas no processo penal. In: Revista da ESMAPE. Vol. 10. № 21. Recife, jan./jun. 2005.

ROMERO COLOMA, Aurelia Maria. El error en material de prueba testifical en el proceso penal. Análisis de un caso practico. In: Actualidad Penal: Publicación Técnico-Jurídica de Derecho Penal. F. 1. Madrid, 1992.

ROSA, Fábio Bittencourt. Proporcionalidade: perigo do conceito aberto. In: Boletim do IBCCrim. No 153. São Paulo, agosto de 2005.

ROSA, Felipe Augusto de Miranda. Quanto tempo demora um processo? In: Revista da Escola da Magistratura do Estado do Rio de Janeiro. Ano 4. № 14. Rio de Janeiro, 2001.

ROUSSEAU, Jean-Jacques. O contrato social e outros escritos. São Paulo: Cultrix, 1971.

ROXIN, Claus. Derecho Penal Parte General. Vol. 1. Madrid: Civitas, 1997. 
RUIVO, Marcelo; BRAGA, Vinícius Gil. Princípio constitucional da proporcionalidade: um instrumento de resistência à expansão do Direito Penal. In: Revista Transdisciplinar de Ciências Penitenciárias. Vol. 2. N 1. Pelotas, jan./dez. 2003.

SAAD, Marta. O direito de defesa no inquérito policial. São Paulo: Revista dos Tribunais, 2001 .

SACCUCCI, Andréa. Le due 'prospettive' della durata ragionevole del processo tra diritto internazionale e diritto interno. In: Giurisprudenza Costituzionale. Ano 47. № 4. Milano, jul./ago. 2002.

SANGUINÉ, Odone. "A inconstitucionalidade do clamor público como fundamento da prisão preventiva". In: Boletim do IBCCrim. Vol. 9. № 107. São Paulo, outubro de 2001.

SANTOS, Leandro Galuzzi dos. "Procedimentos - Lei 11.719, de 20.06.2008". In: MOURA, Maria Thereza Rocha de Assis (coord.). As reformas no processo penal: as novas Leis de 2008 e os projetos de reforma. São Paulo: Revista dos Tribunais, 2008.

SCARTEZZINI, Ana Maria Goffi Flaquer. "A dignidade da pessoa humana e o prazo razoável do processo. A responsabilidade do Estado pela demora na outorga da prestação jurisdicional”. In: MIRANDA, Jorge e SILVA, Marco Antonio Marques da (coord.). Tratado luso-brasileiro da dignidade humana. São Paulo: Quatier Latin, 2008.

SCHIETTI, Rogério. Pela celeridade da justiça criminal. In: Revista Jurídica Consulex. Ano 11. N² 250. Brasília, 15 de junho de 2007.

SCHMIDT, Flávio Ervino. Qual é o prazo razoável?. In: Revista Síntese de Direito Civil e Processual Civil. Vol. 1. No 8. Porto Alegre, nov./dez. 2000.

SERRA, Louise Sebba da Silva. Princípio da proporcionalidade no ordenamento jurídico brasileiro. In: Informativo Jurídico Consulex. Ano 21. № 6. Brasília, 12 de fevereiro de 2007.

SHECAIRA, Sérgio Salomão. Teoria da pena: finalidades, direito positivo, jurisprudência e outros estudos de ciência criminal, São Paulo, Revista dos Tribunais, 2002. 
SILVA, Danielle Souza de Andrade. A temporalidade específica da prisão preventiva. In: Revista CEJ/ Conselho da Justiça Federal, Centro de Estudos Judiciários. Ano 11. No 37. Brasília, abr./jun. 2007.

SILVA, José Afonso da. Curso de direito constitucional positivo. 18. ed. São Paulo: Revista dos Tribunais, 1998.

- A dignidade da pessoa humana como valor supremo da democracia. In: Revista de Direito Administrativo. № 212. Rio de Janeiro, abr.jun. 1998.

SILVA, Luís Virgílio Afonso da. O proporcional e o razoável. In: TORRENS, Haradja Leite e ALCOFORADO, Mario Sawatani Guedes (coords.). A expansão do Direito: estudos de Direito Constitucional e Filosofia do Direito em homenagem a Willis Santiago Guerra Filho (por duas décadas de docência e pesquisas), Rio de Janeiro, Lumen Juris, 2004.

SILVA, Marcelo Cardozo da. Dos princípios e do preceito da proporcionalidade. In: Revista da AJUFE. Ano 23. № 85. Brasília, $3^{\circ}$ trimestre de 2006.

SILVA JÚNIOR, Déllio Lins e. O trancamento do inquérito policial pela falta de razoabilidade no prazo de sua duração. In: Boletim do IBCCrim. Ano 13. № 160. São Paulo, março de 2006.

SIRACUSANO, Fabrizio. Mandato di arresto europeo e durata ragionevole del processo. In: Rivista Italiana di Diritto e Procedura Penale. Ano 46. F. 3. Milano, jul./set. 2003.

SLAIBI FILHO, Nagib. Direito fundamental à razoável duração do processo judicial e administrativo. In: Revista da Escola da Magistratura do Estado do Rio de Janeiro. Vol. 3. No 10. Rio de Janeiro, 2000.

SOUSA, João Castro e. A tramitação do processo penal. Coimbra: Coimbra, 1983.

SOUZA, Sérgio Ricardo de. Temas de Direito Processual Penal Constitucional aplicado. Rio de Janeiro: Ímpetus, 2006.

STEPHENSON, Geoffrey M. The Psychology of Criminal Justice. Oxford: Blackwell, [s./d.] 
TÁCITO, Caio. A razoabilidade das leis. In: Revista de Direito Administrativo. Vol. 204. Rio de Janeiro, abr./jun. 1996.

TESORO, Giorgio. La psicologia della testimonianza. Torino: Fratelli Bocca, 1929.

THUMS, Gilberto. Sistemas processuais penais e a questão do tempo - a EC 45/2004 e o prazo razoável do processo. In: Andrei Zenkner Schmidt (coord.). Novos rumos do Direito Penal contemporâneo: livro em homenagem ao Prof. Dr. Cezar Roberto Bitencourt. Rio de Janeiro: Lumen Juris, 2006.

TORNAGHI, Helio Bastos. Comentários ao Código de Processo Civil. Vol. 1. São Paulo: Revista dos Tribunais, 1974. . Instituições de Processo Penal. Vol. 1. 2. ed. São Paulo: Saraiva, 1977. . Curso de Processo Penal. Vol. 1. 3. ed. São Paulo: Saraiva, 1983.

TOURINHO FILHO, Fernando da Costa. Processo Penal. Vols. 1 e 3. 18. ed. São Paulo: Saraiva, 1997.

TUCCI, Rogério Lauria. Lineamentos do processo penal romano. São Paulo: Bushatsky, 1976.

- Teoria do Direito Processual Penal: Jurisdição, ação e processo penal (estudo sistemático). São Paulo: Revista dos Tribunais, 2002.

. Direitos e garantias individuais no processo penal brasileiro. $25^{\mathrm{a}}$ ed., São Paulo: Revista dos Tribunais, 2004.

. et al. Princípio e regras orientadoras do novo processo penal brasileiro. Rio de Janeiro: Forense, 1986.

VIGORITI, Vincenzo. Notas sobre o custo e a duração do processo civil na Itália. In: Revista de Processo. No 43. São Paulo, [s./d.].

WELZEL, Hans. Derecho Penal Aleman. 4. ed. Santiago do Chile: Jurídica de Chile, 1997. 
WOLTER, Jürgen e FREUND, Georg. El sistema integral del Derecho Penal: delito, determinación de la pena y proceso penal. Trad. Guillermo Benlloch Petit et. all. Madrid: Marcial Pons, 2004.

YACOBUCCI, Guilherme Jorge. El principio de proporcionalidad como regla fundamental de la politica criminal. In: Andrei Zenkner Schmidt (coord.). Novos rumos do Direito Penal contemporâneo: livro em homenagem ao prof. Dr. Cezar Roberto Bitencourt. Rio de Janeiro: Lumen Juris, 2006.

YARSHELL, Flávio Luiz. A reforma do Judiciário e a promessa de “duração razoável do processo". In: Revista do Advogado. Ano 24. N 75. São Paulo, abril de 2004.

ZANFERDINI, Flávia de Almeida Montingelli. Prazo razoável: direito à prestação jurisdicional sem dilações indevidas. In: Cadernos Jurídicos da Escola Paulista da Magistratura. Ano 4. No 13. São Paulo, jan./fev. 2003.

. A crise da Justiça e do processo e a garantia do prazo razoável. In: Revista de Processo. Ano 28. № 112. São Paulo, out./dez. 2003.

ZYLBERMAN, Verônica C. R. Antunes. O princípio da proporcionalidade como instrumento de proteção aos direitos fundamentais. In: Revista do Ministério Público. $\mathrm{N}^{\mathrm{o}}$ 23. Rio de Janeiro, jan./jun. 2006. 